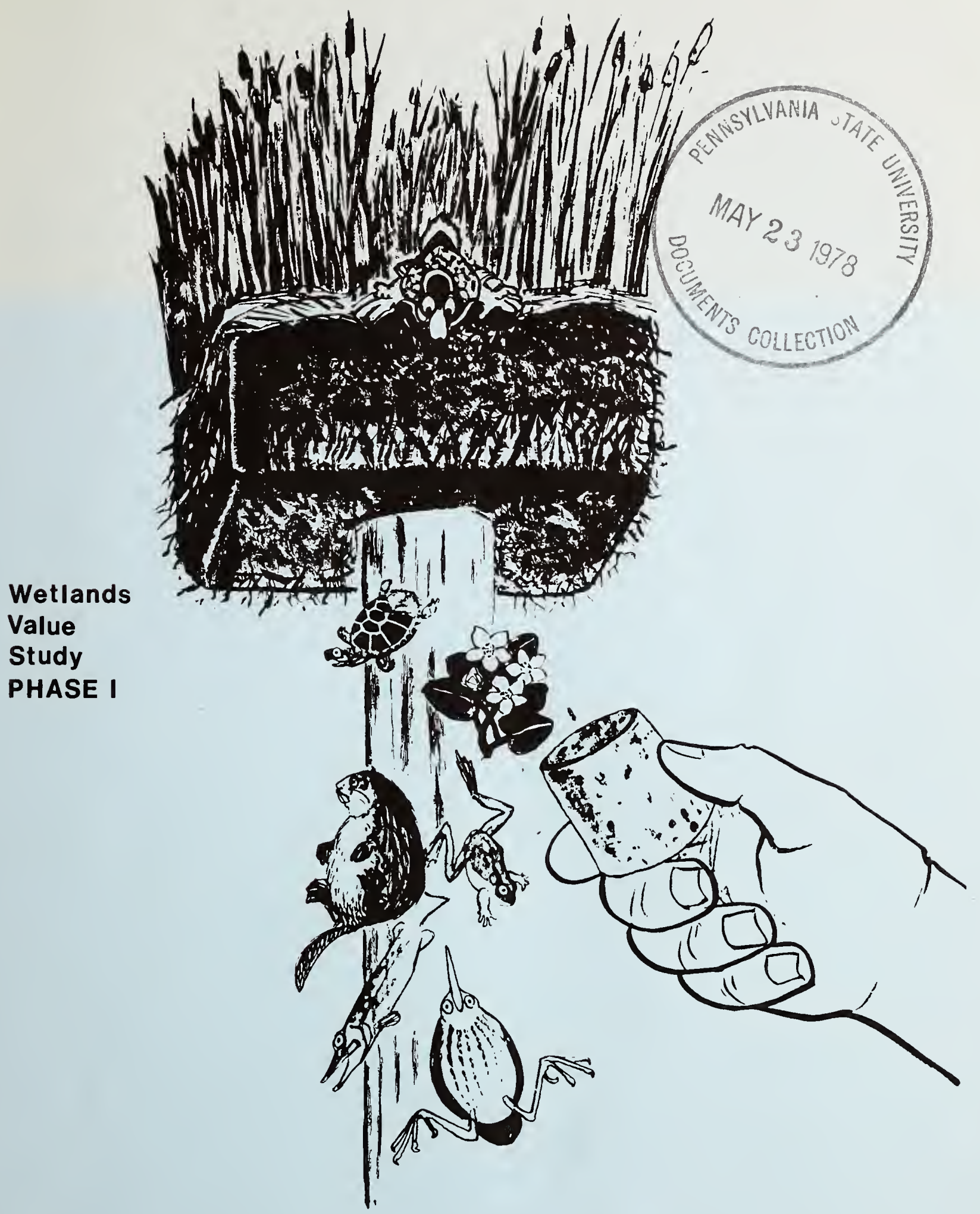

\title{
Fish, Wildlife, and Recreational Values of Michigan's Coastal Wetlands
}




\section{Digitized by the Internet Archive in 2012 with funding from LYRASIS Members and Sloan Foundation}




\section{Fish, Wildlife, and Recreational Values of Michigan's Coastal Wetlands}

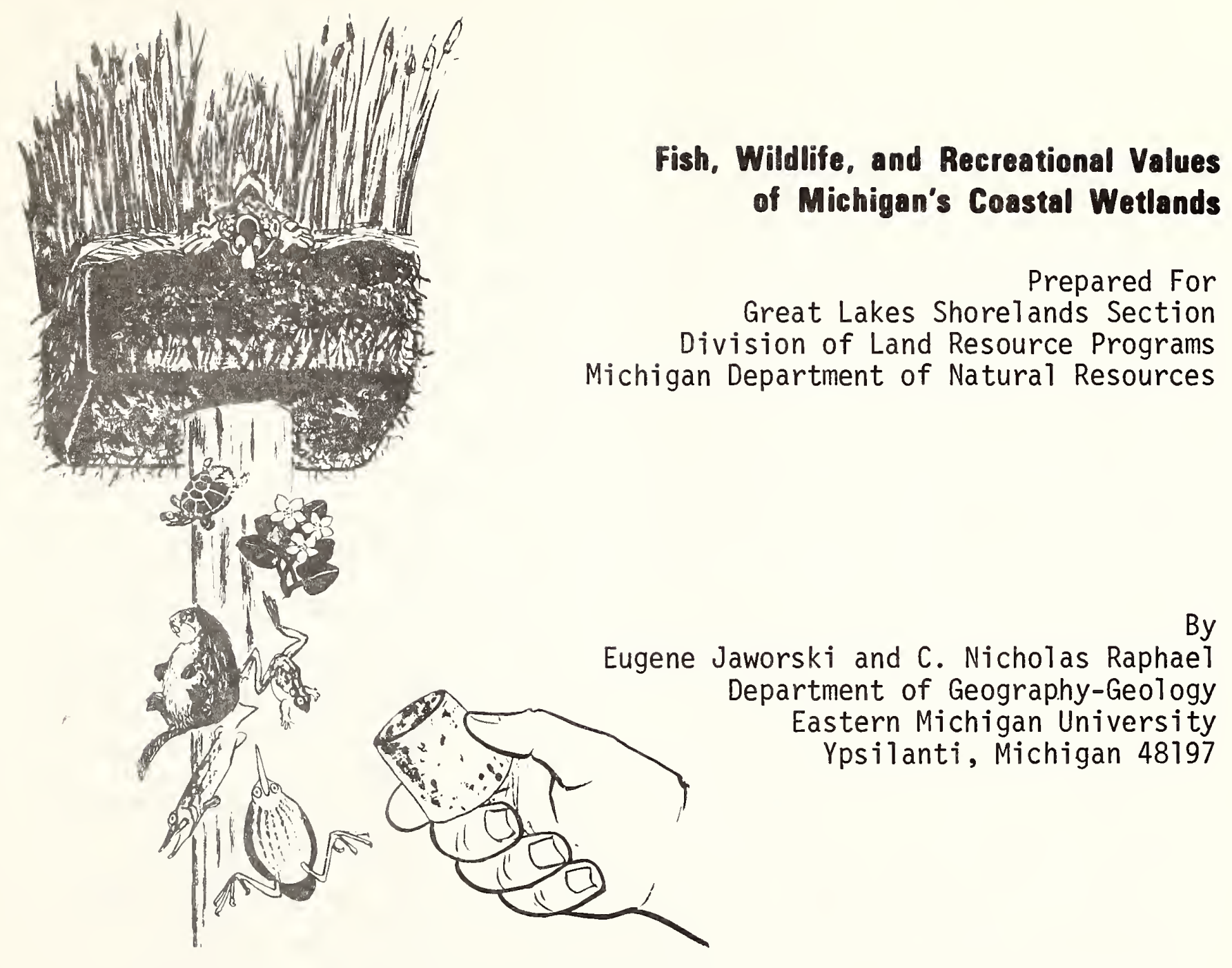

This document was prepared through financial assistance provided by the Coastal Zone Management Act of 1972 administered by the Office of Coastal Zone Management, National Oceanic and Atmospheric Administration.

Printing compliments of the United States Fish and Wildlife Service, a Region III, Twin Cities, Minnesota. 


\section{PREFACE}

Pursuant to the Shorelands Protection and Management Act of 1970 (Public Act 245), as amended, the director of the Michigan Department of Natural Resources (DNR) may designate, as environmental areas, those coastal wetlands necessary for the preservation and maintenance of fish and wildlife. Accompanying the designation of environmental areas is the imposition of shoreland use restrictions (i.e., General Rules, filed 27 Dec. 1973) which the DNR deems appropriate for the preservation of fish and wildlife. However, a local governmental agency, or affected property owner, who contests the designation or shorelands use regulations, will be granted due recourse upon proper petition. At subsequent administrative hearings and litigation, the Department must document the fish and wildlife values of the designated area in question. Various other state and federal programs requiring permits for work in wetlands may also need to document wetlands values and functions to justify permit application decisions.

At present, the Land Resource Programs Division of the DNR is sponsoring a research program referred to as the Coastal Wetlands Value Study. The goal of this research activity, which is to be accomplished in several phases by a university in Michigan acting as a third party, is to collect and summarize existing data on the ecological functions and economic value of Michigan's coastal wetlands. These wetland data will be used to justify the environmental area designations as well as the shorelands use regulations, particularly at future hearings involving 
coastal wetlands. Many other wetland-related programs will benefit from this study, as well. The "Wetlands Inventory Preparatory Study of Michigan" by EMU Wetlands Team, 1977, discovered that a large percentage of the questionnaire respondents are in need of wetlands data to more effectively manage or protect natural resources. The Wetlands Value Study is a beginning toward providing people with improved wetlands data.

Phase One of the Coastal Wetlands Value Study, which is concerned with the fish, wildlife and recreational values, was initiated in February, 1977. In addition to the analysis of selected ecological functions, including fish spawning, shorebird use, furbearer production, and waterfowl breeding and migration, several economic values were documented for Michigan's 105,855 acres of coastal wetlands.

Specifically, Phase One research consisted of a literature review of available source materials concerning wetlands values, analysis of data by geographic area, and map comparisons to document the historical loss of depicted coastal wetland vegetation. Because the study addressed topics of large scope and because the time frame was limited to four months, original research was a minor part of this effort. Moreover, emphasis was placed on annotating key references containing documented wetland values and formatting these annotations to a computer retrieval system. Over 200 references have been annotated. The annotated bibliography is available from the Division of Land Resource Programs. By thoroughly reviewing the available literature, data gaps could be identified which will be utilized to direct future research activities. The authors employed general analytical techniques which took advantage of available data in standard form, e.g., the 1970 National Survey of Fishing and Hunting. Economic values in this Phase One Report are based on 
average annual expenditures by participants engaged in fishing or hunting, or on estimated values of recreation days. Other techniques including willingness to pay models, which may yield less conservative economic values for the coastal wetland resources, could be adopted to the data presented herein. The economic values presented are by no means inclusive because only fish, wildlife and recreation values were examined. Furthermore, the values are not meant to represent current real estate values of the land, but rather dollar productivity of the state's Great Lakes wetland resources.

In perspective, the data contained in this Phase One report represent an interim product which will be complemented by Phase Two and other research activity. For example, the value of Michigan's coastal wetlands with regard to water quality improvement and primary productivity will be addressed in Phase Two (scheduled to be completed May 31, 1978). It should be noted that the Phase One literature review was hampered because the data sources are widely dispersed among many agencies and institutions, and that much of the material is unsummarized in agency reports or otherwise inaccessible. Much of the DNR data collection and presentation methods utilize a broad regional basis as opposed to county or site-specific formats. Thus, data on individual wetland areas were often not available. Changes will be proposed to collect more site-specific wetlands data in the future. This study, although it has some shortcomings, still constitutes a very important effort to quantify and expand the wetlands data base and sets a standard to build upon with additional research.

Chuck Wolverton

Wetlands Value Study Coordinator 
The authors wish to acknowledge the research assistance provided by Brooks B. Williamson and John M. Worthington, Masters degree candidates in the Department of Geography-Geology at Eastern Michigan University. Robin Fox, an undergraduate, also contributed to this report.

This research project was sponsored by the Division of Land Resource Programs, Michigan Department of Natural Resources, Lansing. Special thanks go to Chuck Wolverton and Fred Clinton who provided valuable guidance throughout this study. Gerald Martz and Leo Pospichal of the Wildlife Division of the Michigan Department of Natural Resources were also of assistance during the data collection.

This publication was produced by Michigan's Coastal Program through funding provided by the Coastal Zone Management Act of 1972, as amended, administered by the office of Coastal Zone Management, National Oceanic and Atmospheric Administration, U. S. Department of Commerce. 


\section{ABSTRACT}

A survey of the existing literature pertinent to Michigan's coastal wetlands reveals that these environments provide important ecological functions and economic values to the general public. Compared to the state's total, approximately 21 percent of the waterfowl harvest, 14 percent of the duck production, 11 percent of the muskrat take, 15 percent (by value) of the commercial fish landings, and a large proportion of the sport fishing occurs in the coastal wetlands or adjacent shallow waters. This is significant because a 1972 inventory revealed that Michigan has 105,855 acres of coastal wetlands which represents only 3.5 percent of the state's to total wetland acreage.

In terms of average economic value for fish, wildlife and recreation, Michigan's coastal wetlands contribute an estimated $\$ 489.69$ per wetland acre/year, for a total of $\$ 51.8$ million. Depending on site conditions and recreational use, the annual economic return from individual wetland parcels may vary considerably about this average value. Specifically, these economic values, in decreasing order of value, are: sport fishing (\$286), nonconsumptive recreation $(\$ 138.24)$, waterfowl hunting $(\$ 31.23)$, trapping of furbearers $(\$ 30.44)$, and commercial fishing( $\$ 3.78)$ per wetland acre/year. Inclusion of other values, e.g., for waste assimilation and filtering of suspended solids, as well as ecological values, e.g., use of wetlands by endangered species, could increase the average annual economic return per acre to over $\$ 3,000$. Techniques more comprehensive than those employed in this study 
may yield even less conservative economic values for the fish and wildlife resources.

Historical data reveal that Michigan, since the mid-1800's, has lost approximately 70 percent of its original coastal wetlands. Moreover, available data suggests that at least 20 percent of the existing coastal wetlands may be developed by private interests within the next decade. This projected wetland loss should be carefully evaluated in terms of previous losses, loss of revenue provided by the coastal resources, and by the fact that unsatisfied participant demand for waterfowl hunting and sport fishing already exist in many coastal counties. Waterfowl habitat projections to the year $2000 \mathrm{~A} . \mathrm{D}$. reveal deficiencies for fall migration use in Saginaw Bay and along the southeastern Michigan coast. Although detailed information by individual wetland areas is generally not available, wetlands in Saginaw Bay, Lake St. Clair, Lower Detroit River, and along the western shore of Lake Erie appear to be more significant economically, support the heaviest recreational use, and are, in selected areas, subject to the most intensive developmental pressures. 
TABLE OF CONTENTS

PREFACE. . . . . . . . . . . . . . . . . . $i i$

ACKNOWLEDGMENTS. . . . . . . . . . . . . . . . . v

ABSTRACT . . . . . . . . . . . . . . . . . vi

LIST OF TABLES . . . . . . . . . . . . . . . $\mathbf{x}$

LIST OF FIGURES. . . . . . . . . . . . . . . . . . . . XV

CHAPTER ONE: SUMMARY AND CONCLUSIONS. . . . . . . . . 1

CHAPTER TWO: LOSS OF COASTAL WETLANDS . . . . . . . 11

Coastal Wetland Distribution . . . . . . . 11

Wetland Environments . . . . . . . . . . 14

Wetland Loss....... . . . 18

Lake Erie/Detroit River Wetlands . . . . . . 22

Lake St. Clair Wetlands. . . . . . . . . . . 23

Saginaw Bay Wetlands . . . . . . . . . . . 31

Wetland Losses in the Les Cheneaux Islands. . 35

Little Bay de Noc Wetlands . . . . . . . . 38

Discussion . . . . . . . . . . . . . . . 41

Prospects. . . . . . . . . . . . . . . . . . . 45

Dollar Value of Wetland Losses... . . . . 48

A Regional Perspective of Wetland Loss . . . . 49

CHAPTER THREE: VALUE OF COASTAL WETLANDS TO

WATERFOWL. . . . . . . . . . . 51

Use of Coastal Wetlands for Migration. . . . 51

Fall Migration . . . . . . . . . . 55

Spring Migration . . . . . . . . . . . . 66

Economic Value of Waterfall Migration. . . 70

Loss of Migration Habitat. . . . . . . . . 70

Use of Coastal Wetland as Breeding Habitat . . 75 Value of Waterfowl Hunting in Coastal

Wetlands. . . . . . . . . . . . 88

CHAPTER FOUR: VALUE OF COASTAL WETLANDS TO

FURBEARERS. . . . . . . . . . . . . . . 97

Muskrat Value. . . . . . . . . . . . 97

Raccoons . . . . . . . . . . . . . 104

Conclusion . . . . . . . . . . . . . . 106 
TABLE OF CONTENTS (Continued)

CHAPTER FIVE: COMMERCIAL AND SPORT FISHING VALUES

OF THE COASTAL WETLANDS . . . . . 108

Spawning of Fish in the Coastal Wetlands . . 108 Value of Coastal Wetlands to Commercial

Fishing . . . . . . . . . . . . . . 114

Value of Coastal Wetlands to Sport Fishing . 121

CHAPTER SIX: NONCONSUMPTIVE WETLAND VALUES . . . 136

Unique Geomorphological and Biological

Values. . . . . . . . . . . . . . . . 137

Endangered, Threatened, and Rare Species . . 137

Nesting and Migration of Shorebirds,

Passerines and Birds of Prey in Great

Lake Shorelands . . . . . . . . . . . 150

Other Important Migratory Birds. . . . . 153

Species Diversity. . . . . . . . . . 158

Other Fauna. . . . . . . . . . . . . 159

Wetland Use by Nature Groups . . . . . . 160

Values of Coastal Wetlands for Non-

Consumptive Recreation Uses . . . . . . . . 161

Summary of Nonconsumptive Recreational

Use.................. 170

Efforts to Protect Unique Coastal Sites for

Use........... 171

CHAPTER SEVEN: FISH AND WILDLIFE PRODUCTIVITY BY

GEOGRAPHIC REGION. • . . . . . . . 174

Matrix of Coastal Wetland Values . . . . 179

An Overview of Wetland values. . . . . 180

Key References............ . 182

APPENDIX . . . . . . . . . . . . . . . . . . . . . 191

REFERENCES CITED . . . . . . . . . . . . 192 


\section{LIST OF TABLES}

Table

Page

1. LINEAR MILES OF SHORELAND IN MICHIGAN ...... . 11

2. ACRES OF COASTAL WETLANDS IN MICHIGAN, 1972 . . 12

3. CORRELATION BETWEEN CIRCULAR 39 AND THE NATIONAL WETLAND INVENTORY. . . . . . . . . . . 19

4. ACRES OF WETLAND LOSSES IN SELECTED COASTAL AREAS . . . . . . . . . . . . . . . . . 22

5. COASTAL WETLAND LOSSES AND GAINS IN LAKE ERIE AND LOWER DETROIT RIVER . . . . . . . . . . . 23

6. WETLAND LOSSES IN LAKE ST. CLAIR. . . . . . . 28

7. COASTAL WETLAND LOSSES AND GAINS IN SAGINAW BAY . 34

8. WETLAND LOSSES IN THE LES CHENEAUX ISLANDS. . . . 38

9. WETLAND LOSSES IN LITTLE BAY DE NOC 1910-1958 . . 41

10. PROBABLE CAUSES OF WETLAND LOSSES IN SELECTED AREAS . . . . . . . . . . . . . . . . 42

11. EXISTING AND PROJECTED SHORELAND USE IN LINEAR MILES . . . . . . . . . . . . . . . . . . 47

12. ESTIMATED ACQUISITION COST OF SELECTED COASTAL WETLANDS IN MICHIGAN. . . . . . . . . . .52

13. DUCK, GOOSE, AND SWAN SPECIES WHOSE PRIMARY AND SECONDARY MIGRATION CORRIDORS TRAVERSE THE STATE OF MICHIGAN . . . . . . . . . . . . . . 57

14. WATERFOWL CONCENTRATION AREAS IN COASTAL WETLANDS FALL MIGRATION, IN MICHIGAN, 1976 . . . . 58

15. ESTIMATED WATERFOWL DAY USE BY COASTAL WETLAND IN MICHIGAN, 1955 . . . . . . . . . . . .60 


\section{LIST OF TABLES (Continued)}

Table

Page

16. SPECIES COMPOSITION OF WATERFOWL OBSERVED

DURING FALL MIGRATION LAKE ST. CLAIR, MI, OCT.

7 THROUGH DEC. 3, 1974 . . . . . . . . . . 62

17. UTILIZATION OF PLANT FOODS BY 150 DUCKS AND

COOTS HARVESTED AT ERIE SHOOTING CLUB, 1959.. . 64

18. SPRING MIGRATION CALENDAR BY WATERFOWL SPECIES IN MICHIGAN'S COASTAL WETLANDS . . . . . . .68

19. AERIAL SURVEY OF SPRING WATERFOWL MIGRATIONS

FISH POINT AND SEBEWAING BAY, 1967, 1969, 1971,

1977 . . . . . . . . . . . . .69

20. LIST OF THREATENED COASTAL WETLANDS WHICH

FUNCTION FOR WATERFOWL MIGRATION, IN MICHIGAN, 1976 . . . . . . . . . . . . . . . 72

21. DEFICIENCIES IN FUTURE MIGRATION AND WINTERING HABITAT IN MICHIGAN BY FLYWAY HABITAT REGION, YEAR 2000 A. D., IN 1000's OF WATERFOWL. . . . 74

22. SPECIES OF DUCKS NESTING IN THE COASTAL WETLANDS AND IN FORESTED INTERIOR OF MICHIGAN, AND MAGEE MARSH, N. OHIO . . . . . . . . . . . .76

23. NUMBER OF BREEDING PAIRS OF DUCKS IN MICHIGAN, 1976 . . . . . . . . . . . . . . . 78

24. ESTIMATE PROPORTION OF MICHIGAN'S ANNUAL DUCK HARVEST WHICH DERIVES FROM STATE-REARED WATERFOWL . . . . . . . . . . . . . . . . .79

25. AVERAGE SPECIES COMPOSITION OF RETRIEVED DUCK SAMPLE STATE AVERAGE (1965-1974) vs. ST. CLAIR FLATS SGA (1974-1975) . . ........ 80

26. DUCK NESTING DENSITIES IN COASTAL WETLANDS OF MICHIGAN, 1951-1966. . . . . . . . . . 81

27. DENSITY OF DUCK BROODS IN MICHIGAN WETLANDS, 1949 . . . . . . . . . . . . . 82

28. BIOLOGISTS' ESTIMATES OF NESTING PAIRS AND DUCKLING PRODUCTION IN MICHIGAN COASTAL WETLANDS, 1975................. . . 83 


\section{LIST OF TABLES (Continued)}

Table

Page

29. WATERFOWL BREEDING HABITAT IN COASTAL WETLANDS THREATENED BY PRIVATE DEVELOPMENT WITHIN 5 YEARS, MICHIGAN, 1976 . . . . . . . . . 87

30. ANNUAL WATERFOWL HARVEST IN MICHIGAN, 19711975, DNR ESTIMATES . . . . . . • • . . . . 89

31. AVERAGE DUCK HARVEST IN THE COASTAL COUNTIES OF MICHIGAN, 1961-1970 ANNUAL AVERAGE, U. S. $F$ AND $W$ ESTIMATES

32. COMPARISON OF NUMBER OF APPLICATIONS TO NUMBER OF AVAILABLE WATERFOWL HUNTING RESERVATIONS AT FISH POINT, NAYANQUING POINT, AND ST. CLAIR FLATS STATE WILDLIFE AREAS, 1976. • • • • • . . 93

33. FURBEARERS, TRAPPERS AND FUR VALUE IN MICHIGAN (1971-1972) . . . . . . . . • . . . 98

34. MUSKRATS HARVESTED BY TRAPPERS, 1967-1971 IN MICHIGAN . • • • • • • . • • • . . • • • • • • • 99

35. MUSKRAT TAKE IN SELECTED COUNTIES OF SOUTHEASTERN MICHIGAN, 1965-1970......... 100

36. MUSKRAT TAKE PER WETLAND ACRE AND PER CATTAIL ACRE IN SELECTED COUNTIES OF SOUTHEASTERN MICHIGAN. . . . . . . . . . . . . . . 102

37. ESTIMATED RACCOON HARVEST IN MICHIGAN, 19711975 .

38. FISH SPECIES SPAWNING IN COASTAL WETLANDS OF MICHIGAN. . . . . . . . . . . . . . . 109

39. COMMON FISH SPECIES UTILIZING THE COASTAL WETLANDS OF MICHIGAN. . . . . . . . • • . . . 114

40. FISH SPECIES INHABITING COASTAL WETLANDS WHICH ARE TOLERANT TO TURBIDITY, SILTATION, AND POLLUTION . . . . . . . . . . . . . . 115

41. VALUE OF COMMERICAL FISH LANDINGS FROM MICHIGAN WATERS OF THE GREAT LAKES, BY LAKE AND BY SPECIES, 1976 


\section{LIST OF TABLES (Continued)}

Table

Page

42. COMMERCIAL FISH LANDINGS IN SAGINAW BAY (LAKE HURON) BY SPECIES, 1975 . . . . . . . . . 118

43. COMMERCIAL FISH LANDINGS FROM MICHIGAN'S COASTAL WATERS OF LAKE ERIE, BY SPECIES, $1975 . .120$

44. NUMBER OF SPORT FISHERIEN AND FISHING EFFORT BY TYPE OF SPORT FISHING, IN MICHIGAN, 1975 . . 123

45. NUMBER AND RESIDENCE OF GREAT LAKES YELLOW PERCH FISHERMEN BY REGION, IN MICHIGAN, 1975. . 124

46. SPORT FISH CATCH AND FISHING EFFORT IN SAGINAW BAY BY SPECIES, 1975............... 128

47. MICHIGAN NON-SALMONID SPORT FISH CATCH AND FISHING EFFORT, LAKE ST. CLAIR VS. OTHER MICHIGAN GREAT LAKES WATERS, 1975 . . . . . . . 130

48. ESTIMATED ECONOMIC VALUE OF COASTAL WETLANDS TO SPORT FISHING, SELECTED COASTAL AREAS, IN MICHIGAN, 1977. . . . . . . . . . . . . . . 133

49. PROJECTED ANGLER PARTICIPATION IN SPORT FISHING IN MICHIGAN, RESIDENT DEMAND VS. TOTAL DEMAND, BY SUBAREA, 1980. . . . . . . . . . . . . . . 135

50. ENDANGERED, THREATENED AND RARE FAUNA IN GREAT LAKES COASTAL WETLANDS. . . . . . . . . . . 140

51. ENDANGERED, THREATENED AND RARE FLORA IN GREAT LAKES SHORELANDS. . . . . . . . . . . . . . . . 146

52. HABITATS OF PROBABLY EXTINCT, ENDANGERED, AND THREATENED PLANTS IN MICHIGAN .. . . . . . . . . 151

53. AVIFAUNA IN THE COASTAL GREAT LAKES . . . . . . 152

54. COASTAL MIGRATION SITES OF SHOREBIRDS, PASSERINES AND RAPTORS. . . . . . . . . . . 155

55. WETLAND USE BY NATURE GROUPS (NUMBER OF PEOPLE) .162

56. NON-HUNTING VS. HUNTING USE OF PUBLIC WATERFOWL GAME AREAS . . . . . . . . . . . . . . . . . 164 
Table

57. NON-HUNTING AND HUNTING USE OF ST. CLAIR FLATS WILDLIFE AREA PRELIMINARY DATA FOR LOWER HARSENS ISLAND . . . . . . . . . . . . . 167

58. UNSATISFIED PARTICIPATION IN NONCONSUMPTIVE USE OF WILDLIFE HABITAT BY PLANNING SUBBASIN IN MICHIGAN, FOR SELECTED YEARS, IN 1800'S OF MAN DAYS ................. . 170

59. PROPOSED NATURAL COASTAL AREAS UNDER CONSIDERATION BY THE DNR . . . . . . . . . . . . 173

60. POTENTIAL AVERAGE ANNUAL COASTAL FISH AND WILDLIFE PRODUCTION. . . . . . . . . . . . 175

61. POTENTIAL AVERAGE ANNUAL ECONOMIC VALUE OF FISH, WILDLIFE, AND NONCONSUMPTIVE RECREATIONAL RESOURCES OF COASTAL WETLANDS IN MICHIGAN BY GEOGRAPHICAL AREA, 1977. . . . . 177

62. MATRIX OF PAGE NUMBERS FOR DOCUMENTED VALUES OF COASTAL WETLANDS IN MICHIGAN. . . . . . . 184 


\section{LIST OF FIGURES}

Figure

Page

1. DISTRIBUTION OF COASTAL WETLANDS IN MICHIGAN . 13

2. THE LACUSTRINE ECOLOGICAL SYSTEM, WETLANDS CLASSIFICATION . . . . . . . . . . . . . . 16

3. THE PALUSTRINE ECOLOGICAL SYSTEM, WETLANDS CLASSIFICATION . . . . . . . . . . . . . . . 17

4. DISTRIBUTION OF RAISIN RIVER WETLANDS IN 1915. . 24

5. DISTRIBUTION OF RAISIN RIVER WETLANDS IN 1974. . 25

6. COASTAL WETLANDS OF SOUTHERN MONROE COUNTY IN 1901 . . . . . . . . . . . . . . . 26

7. COASTAL WETLANDS OF SOUTHERN MONROE COUNTY IN 1974 . . . . . . . . . . . . . . . . . . . 27

8. COASTAL WETLANDS IN LAKE ST. CLAIR, 1873 . . . 29

9. COASTAL WETLANDS IN LAKE ST. CLAIR, 1973 . . . 30

10. SAGINAW BAY WETLANDS IN 1857 . . . . . . . . 32

11. SAGINAW BAY WETLANDS IN 1963-1973. . . . . . . 33

12. THE LES CHENEAUX WETLANDS IN 1904. . . . . . 36

13. THE LES CHENEAUX WETLANDS IN 1964. . . . . . 37

14. THE LITTLE BAY DE NOC WETLANDS IN 1910 . . . 39

15. THE LITTLE BAY DE NOC WETLANDS IN 1958... . . 40

16. PROJECTED COASTAL LAND USE FOR LAKE HURON AND LAKE ERIE. . . . . . . . . . . . . . . . . . . .46

17. FALL MIGRATION CORRIDORS OF DIVING DUCKS ACROSS MICHIGAN . . . . . . . . . . . . . . 52 


\section{LIST OF FIGURES (Continued)}

Figure

18. FALL MIGRATION CORRIDORS FOR DABBLING DUCKS ACROSS MICHIGAN . . . . . . . . . . . .53

19. FALL MIGRATION CORRIDORS FOR CANADA GEESE ACROSS MICHIGAN . . . . . . . . . . . 54

20. FALL CONCENTRATION AREAS FOR MIGRATORY WATERFOWL, IN MICHIGAN, 1977 (MICHIGAN'S COASTAL WETLANDS) . . . . . . . . . . . . 56

21. THREATENED MIGRATION HABITATS IN THE COASTAL WETLANDS OF MICHIGAN. . . . . . . . . . 73

22. SPORT FISHING AREAS IN THE COASTAL WETLANDS OF THE ST. CLAIR DELTA ........... 129

23. VEGETATION TRANSECT ON HARSENS ISLAND, ST. CLAIR RIVER DELTA . . . . . . . . . . 138

24. MIGRATION SITES OF SHOREBIRDS, PASSERINES AND RAPTORS, IN MICHIGAN. . . ....... 154

25. PROPOSED NATURAL AREAS IN COASTAL MICHIGAN. . 172 


\section{CHAPTER ONE \\ SUMMARY AND CONCIUUSIONS}

The following conclusions have been determined in this study.

Coastal Wetland Loss. According to the 1972 shoreland inventory, the state has 105,855 acres of coastal wetland or 3.3 percent of Michigan's total wetlands. Historically, Little Bay de Noc, Les Cheneaux Islands, Saginaw Bay, Lake St. Clair, and the Detroit River/Lake Erie (Monroe County) had 70,125 acres of coastal wetlands. These areas now total 28,522 acres. In these investigated areas, the wetland loss totalled 41,550 acres. Based on the present market price, the value of the dollar loss totals $\$ 45,133,687$. This loss however, does not include dollar losses for fish, wildlife and nonconsumptive recreation which is estimated to be $\$ 20,346,619$.

In the past, significant wetland losses have occurred because of land being drained for agricultural purposes. More recently, urbanization to include industrial expansion, has been responsible for wetland losses. Future projections indicate that residential, industrial and commercial expansion in the state's shorelands will continue to increase.

Use of Coastal Wetlands by Migratory Waterfowl. Because the main flyway corridor of several species, including the whistling swan, Canada geese, canvasback, bufflehead, ruddy duck, hooded merganser and American goldeneye traverse Michigan, these waterfow1 are dependent upon Michigan's coastal wetlands and shallow water habitats for resting and feeding. A number of coastal wetlands, in particular those along Portage Bay, St. Martins Bay, Saginaw Bay, Lake St. Clair, 
lower Detroit River, and coastal Monroe County, function as concentration areas during fall and spring migrations. The economic value of concentration areas for these continental waterfowl populations cannot be measured.

Projection of migratory waterfowl habitat needs indicate that southeastern Michigan is exhibiting habitat deficiencies for fall and spring migration and for wintering of waterfow 1 . Likewise, at Saginaw Bay-Thumb area, habitat deficiency for fall migration in year 2000 A.D. has been projected. At present, an estimated 32,645 acres of coastal migration habitat, particularly in southern Michigan, is tirreatened by private development within the next decade. This amounts to 31 percent of the total coastal wet 1 and area.

Value of Coastal Wetlands to Waterfowl Breeding. The mute swan nests in the Grand Traverse Bay area, and the redhead duck, which breeds in Michigan only in restricted areas, nests in the St. Clair delta. The most common waterfowl species nesting in the coastal wetlands besides coot, in ranked order, are mallards, blue-winged teal, and black ducks. High-density breeding areas include Nayanquing Point, Tobico Marsh, St. Clair Flats, Arcadia Marsh, Quanicassee, Portage Entry Marsh (Houghton County), and Portage Marsh (De1ta County).

The coastal wetlands produce an average of 0.31 flying ducklings per acre, or 32,815 total ducks annually. This production contributes an estimated 14 percent of the annual duck production within the state. Though the number of Canada geese reared within the state is relatively small, state-produced geese are expanding in numbers and are making an increasing contribution to the annual goose harvest. Even though the coastal wetlands are of limited extent, production of ducks and coots is comparatively high. Unfortunately, an estimated 18,362 acres of coastal waterfow 1 breeding habitat are threatened by development 
within the next 5-10 years. This acreage amounts to 17 percent of the total coastal wetlands area.

Standard Values for Economic Ássessment of Wetland

Values. The economic value of the fish, wildlife and nonconsumptive recreational resources were based on estimates of sport and commercial harvests, average annual expenditures by participants engaged in fishing and hunting, and on values of recreation days. (See table of standard values on the next page). This methodology was employed to estimate the average annual dollar value generated directly from an acre of Michigan's coastal wetlands. Value of Coastal Wetlands to Waterfowl Hunting. Because waterfowl tend to concentrate, during migration, in the coastal wetlands and because large areas of wetlands have been set aside for public hunting, approximately 21 percent of the annual harvest of ducks occurs therein. Waterfowl hunting in the coastal wetlands, which centers on dabbling ducks, contributes $\$ 3,305,913$, including carcass value, to the economy of Michigan. This economic assessment is based on $\$ 130.25$ per waterfowl hunter per year and $\$ 1.13$ /pound of waterfowl carcass value, resulting in a value of approximately $\$ 30.00$ per retrieved waterfowl, or $\$ 31.23$ per wetland acre/year. An estimated annual harvest of 85,9 y0 waterfowl or 0.81 birds/acre/year has been calculated for the coastal wetlands. A proportion of the waterfowl reared in Michigan's coastal wetlands also provide hunting opportunities in other states as well.

The annual harvest of waterfowl at the Fish Point and St. Clair Flats Wildlife Areas is exceptionally high. Present waterfowl hunting participation and latent demand in southeastern Michigan and in the Saginaw Bay-Thumb area indicate a deficiency of hunting opportunities, particularly at high-quality hunting areas during preferred times.

Value of Coastal Wetlands to Furbearers. The principal furbearers in the coastal wetlands are raccoons 
and muskrats. The number of muskrats trapped increases from nortin to south with 11 percent of the state's harvest recorded in the coastal counties of Region III. Given an average harvest of three muskrats per acre and a combined pelt and carcass value in 1977 of $\$ 8.70 /$ animal, muskrats generate a value of $\$ 26.10 /$ wetland acre/year. In the cattail marshes, the average annual value for muskrats is $\$ 29.75 /$ acre. Raccoons, winich average 0.11 furbearers per wetland acre and \$39.40/animal, yield a dollar value of $\$ 4.34 /$ wetland acre/year. Together these two mammals produce an average annual return of $\$ 30.44 /$ wetland acre/year. Value of Coastal Wetlands as Fish Spawning, Nursing and Feeding Habitat. The coastal wetlands of Michigan provide spawning habitat for northern pike, yellow perch, carp, smallmouth bass, largemouth bass, bluegill, bullheads, and several other species including forage minnows. Loss of habitat due to agricultural and residential encroachment and water quality deterioration due to agricultural, urban and agricultural runoff have greatly fragmented and degraded many coastal spawning areas, especially along western Lake Erie, lower Detroit River, and Saginaw Bay. A deficiency of spawning habitat may exist for wetland dependent species, e.g., the northern pike. Three important wetland spawning areas are located in Lake St. Clair, St. Marys River, and Little Bay de Noc.

Value of Coastal Wetlands to Reptiles and

Amphibians. Turtles, snakes and frogs are important predators as well as a food source for higher wetland predators. Turtles are particularly significant as scavengers. Though not well researched, this group represents an important link in the wetland food web, adds species diversity, and provides non-consumptive recreation.

Value of Coastal Wetlands to Commercial Fishing.

Because of environmental deterioration and subsequent decline in fish stocks, and the restriction on many highvalue species such as walleye and northern pike, commercial fishing in the coastal wetlands focuses on medium-to-lowvalue, warmwater species, e.g., carp, yellow perch, channel 
catfish, and freshwater drum. In 1977, the total harvest by 33 fishermen amounted to approximately 1,810,000 pounds, which was valued at about $\$ 400,000$. Most of the fishing activity occurs in Saginaw Bay, with small commercial landings also in the St. Marys River and along western Lake Erie.

The catch in the coastal wetlands contributes 12 percent of the total weight of the statewide harvest, and approximately 15 percent of the total value. Given 105,855 acres of coastal wetland, the harvest therein on the average amounts to 17.1 pounds per acre/year, for an economic value in 1977 of $\$ 3.78$ per wetland acre/year. However, if carp are raised in wetland ponds, the return is estimated to be $\$ 30.85 /$ wet 1 and acre/year. If all of Michigan's Great Lakes commercial fish catch was considered to be wetland dependent, then the average value would amount to approximate1y $\$ 30.00$ per wetland acre/year. 
STANDARD VALUES FOR ESTIMATING ANNUAL ECONOMIC RETURN FROM MICHIGAN'S COASTAL WETLANDS

\footnotetext{
Wetland Uses or Products

Average Annual Waterfowl Hunter's Expenditures

Waterfow1 Hunting Day

Average Annual Freshwater Fisherman's Expenditures

Angler Day (Freshwater Sport Fisherman)

1977 Value

$\$ 130.25$

15.00

196.10

9.72

Source: U.S. Dept. of Interior, 1972, "1970 National Survey of Fishing and Hunting", Resource Pub. 95, Wash., D.C., 108 pp. Extrapolation from 1970 to 1977 based on 1.542 cost-of-living factor.

Commercial Fish (Wholesale Price to Fishermen)

Average for Warmwater Coastal Fish

$\$ 0.22 / 1 b$.

Furbearers

Muskrat - Pelt

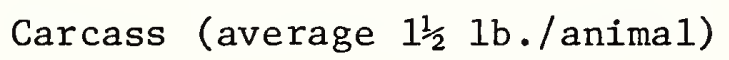

$\$ 7.00$ each

$1.13 / 1 b$.

Raccoon - Pelt

Carcass (average 7 lbs./animal)

$\$ 31.50$ each

$1.13 / 1 b$.

Waterfow1 Carcass Values:

Duck (average 1 1b./bird)

Goose (average 4 lbs./bird)

$\$ 1.13 / 1 \mathrm{~b}$.

Coot (average 1 1b./bird)

$1.13 / 1 b$.

$1.13 / 1 \mathrm{~b}$.

Source: Current Files, Fisheries Division and Wildlife Division, Michigan Dept. of Natural Resources, Lansing, MI. Furbearer carcass and waterfowl carcass values were extrapolated from 1975 to 1977 using a 1.129 cost-of-living factor.
}

Nonconsumptive Recreation:

Average Annual Participant Expenditures

Recreation Day

$\$ 200.75$

23.12

Source: Based on Payne B. B. and R. M. DeGraaf, "Economic Value Associated with Human Enjoyment of Nongame Birds", General Technical Report No. WO-1, Wash., D.C., USDA, Forest Service, 1975, pp 6-10. 
Value of Coastal Wetlands to Sport Fishing. Some of the Great Lakes non-salmonid sport fishing in Michigan, which amounts to 4.4 million angler days per year and is valued at $\$ 43.4$ million annually, occurs in coastal wetlands. Because many of the warmwater species which comprise most of Great Lakes sport fishery, such as northern pike and yellow perch, spawn in or are otherwise dependent on coastal wetlands, the coastal environments contribute to the fishery even though much of the actual catch may not take place directly in wetlands. Yellow perch is the species of primary importance to Great Lakes non-salmonid fishermen.

Lake St. Clair and Lake Huron account for 75 percent of the Great Lakes non-salmonid fishing effort and 81 percent of the total yellow perch catch. Lake St. Clair, including its deltaic wetlands, is probably the most valuable sport fishing area in the Great Lakes. The economic value of sport fishing in the coastal wetlands varies considerably, but on the average amounts to $\$ 286$ per wetland acre/year. Proximity to large urban centers is a major factor influencing use rates. At present, Lake St. Clair and Saginaw Bay are receiving heavy hook and line fishing pressure. Current and projected angler demand indicate that a lack of sufficient inland fishing opportunities in southern Michigan is being compensated to some extent by the exporting of demand to Lake St. Clair, Saginaw Bay, and to northern Michigan. Value of Coastal Wetlands to Nonconsumptive Uses. Coastal wetlands are utilized for nesting and concentration areas by endangered, threatened, and rare fauna and flora as well as by the many abundant species of shorebirds, passerines, and birds of prey. Recreational non-hunting and non-fishing activity hours greatly exceed hunting activities and this demand is increasing. The economic value of nonconsumptive recreational use is estimated to be $\$ 138.24 /$ acre/year. 
Summary of Wetland Values Per Acre. The economic. value of Michigan's wetlands with regard to fish, wildlife and nonconsumptive recreation uses totals $\$ 477.78 /$ acre/year and is divided as follows:

Sport Fishing

Nonconsumptive Recreation

Waterfow 1 Hunting

Trapping of Furbearers

Commercial Fishing
$\$ 286.00 /$ acre/year

$\$ 138.24$

$\$ 31.23$

$\$ 30.44$

$\$ 3.78$

TOTAL \$489.69/acre/year Non-economic values, e.g., use by endangered species.

According to a 1972 survey, the coastal wetlands in Michigan total 105,855 acres. Employing an average annual return of $\$ 489.69$ per acre, fish, wildife and nonconsumptive recreation generate a direct annual gross value of $\$ 51,836,137$ to the State of Michigan and its users. Most of the annual economic return in this economic assessment are public values as opposed to an average income a private landowner might expect from his property. Thus, provided the public has access to the wetlands and multiple use is made of the available resources, wetlands may generate several hundred dollars worth of gross annual return per acre.

These economic values do not represent all the economic values of an acre of coastal wetland. At the National Wetland Symposium (Washington, D.C., June 6-8, 1977) many investigators suggested that the role of wetlands with regard to pollution-absorbing capabilities greatly exceeds the dollar value of wildlife and agricu1ture. It has been determined that the dollar value per wetland acre for phosphrous removal, secondary and tertiary waste treatment may be $\$ 3,730 /$ acre/year (Sullivan, 1976, p. 4). 
Potential Wetland Value by Geographic Region. By multiplying the total estimated wetland value per acre (\$489.69) by the acreage of wetland, the potential average annual return per geographical region was calculated.

\begin{tabular}{|c|c|c|c|}
\hline & $\begin{array}{l}\text { Wetland } \\
\text { Acreage }\end{array}$ & $\begin{array}{l}\text { Dollar Value } \\
\text { of Wetlands }\end{array}$ & $\begin{array}{l}\text { Percent of } \\
\text { Grand Total }\end{array}$ \\
\hline Lake Superior & 1,200 & $\$ \quad 587,628$ & 1.1 \\
\hline St. Marys River & 11,978 & $5,865,507$ & 11.3 \\
\hline Lake Michigan & 29,846 & $14,615,288$ & 28.2 \\
\hline Lake Huron, excl. & & & \\
\hline Saginaw Bay & 5,686 & $2,784,378$ & 5.4 \\
\hline Saginaw Bay & 33,380 & $16,345,851$ & 31.5 \\
\hline Lake St. Clair & & & \\
\hline$\&$ St. Clair R. & 15,630 & $7,653,854$ & 14.8 \\
\hline Detroit River & 1,420 & 695,361 & 1.35 \\
\hline Lake Erie & 6,715 & $3,288,270$ & 6.35 \\
\hline TOTALS & 105,855 & $\$ 51,836,137$ & $100.0 \%$ \\
\hline
\end{tabular}

The Lake St. Clair wetlands, because of its intense sport fishing and high potential nonconsumptive recreational use, probably comprises Michigan's most valuable coastal wetland. Saginaw Bay wetlands appear to rank second. Both areas are in close proximity to large urban centers, have the highest latent participation demand for sport fishing, waterfowl hunting, and nonconsumptive recreation, and exhibit forecasted habitat deficiency for migratory waterfowl.

Data Availability and Sources. Most data used in this report were obtained by the Fisheries Division and Wildlife Division of the Michigan DNR. The data in general consisted of typed or xerox reports and were often presented on a region or at best, county level. In many cases, the data were collected by counties through the mid-1950's. The data on file since that time were reported by region. There were only fragmentary data available by wetland location.

Since the DNR may be required to protect wetlands in the near future, it is recommended that a file be prepared for each of the state's wetlands. With the present 
organization of the data, it is not possible to promptly obtain wetland information on a specific wetland. Because of the potentially high value per wetland area, sport

fishing and nonconsumptive recreation should be emphasized in value assessments. 
CHAPTER TWO

LOSS OF COASTAL WETLANDS

In recent years, with record high lake levels, a great deal of concern, research, and funding has been concentrated on coastal erosion problems in the Great Lakes. Most investigations by state and federal agencies concentrated their efforts on bluff erosion and coastal flooding (Great Lakes Basin Commission, 1975b; Bryan, 1976). The concern for wetland losses, although perhaps more significant because of their vital link between terrestrial and aquatic habitats has not been adequately identified, mapped, or addressed. In this chapter an overview of coastal wetland changes is presented based upon the available literature and the mapping of selected wetlands in the state of Michigan.

COASTAL WETLAND DISTRIBUTION

Michigan has some 2,138 miles of mainland shoreline (Table 1) which is composed of a variety of geologic materials such as bedrock, glacial debris and finer lake plair. sediments.

TABLE 1

LINEAR MILES OF MAINLAND SHORELINE IN MICHIGAN

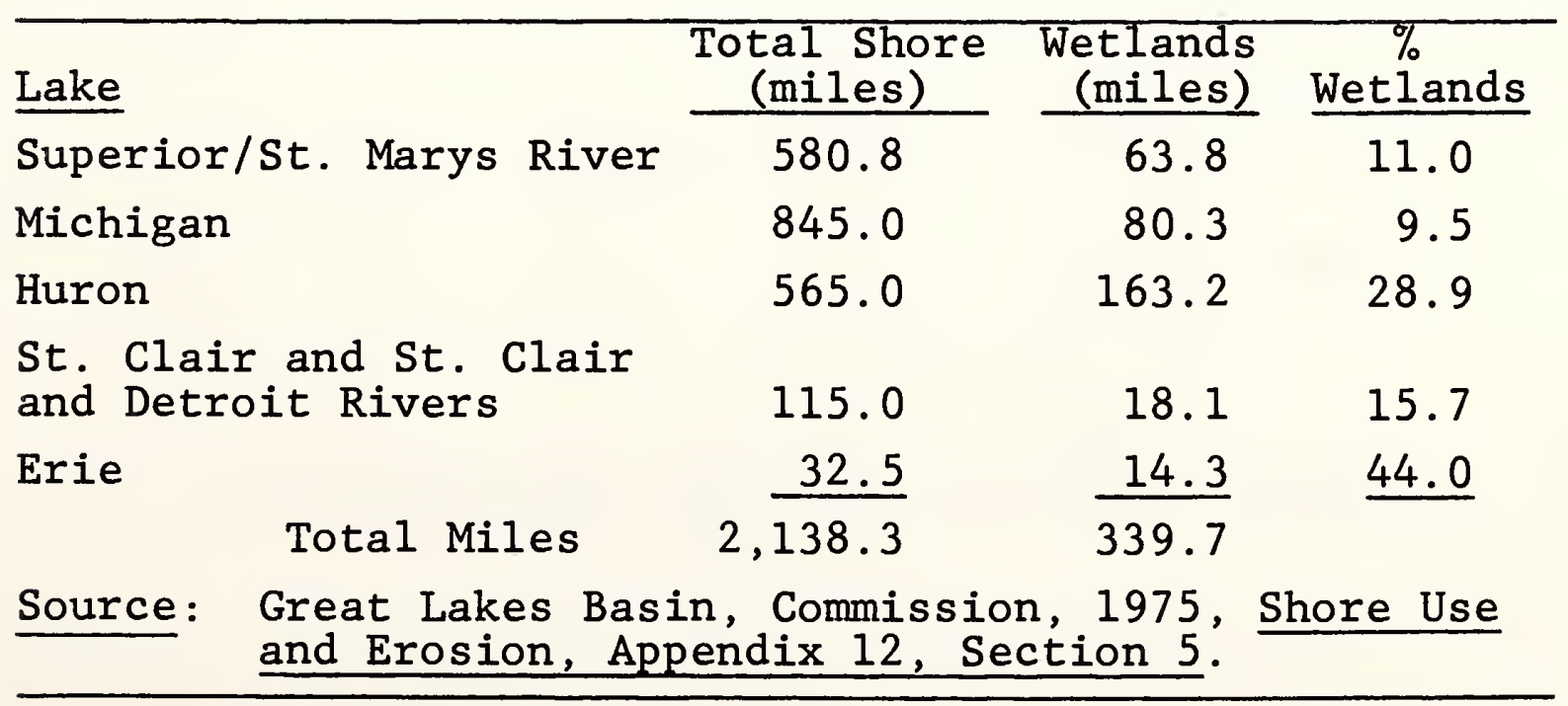


Coastal wetlands occupy only 340 miles or 16 percent of the State's shorelands. The highest percentage of Michigan's wetland communities occur on low, clay plains on Lake Erie and Lake Huron. However, significant concentrations occur in protected embayments surrounded by bedrock or thin glacial deposits such as in Little Bay de Noc, Potagannissing Bay, and Munuscong Bay.

Figure 1 illustrates the distribution of coastal wetland acreage in Michigan. As determined by these data, a total of 105,855 acres of coastal habitat existed in 1972. As noted in Table 2, the habitat concentration is greatest in Lake Huron. Four counties (Huron, Tuscola, Bay, and Arenac) adjacent to Saginaw Bay account for 34,726 acres or 33 percent of the state's total coastal wetland acreage. In the Upper Peninsula, significant wetland areas occur in eastern Chippewa County $(11,978$ acres). Most of the 29,785 acres in Lake Michigan are located in lakes and estuaries landward of Lake Michigan such as the estuary of Grand River, Lake Macatawa, and Muskegon Lake.

TABLE 2

ACRES OF COASTAL WETLANDS IN MICHIGAN, 1972

Lake Acres

Lake Huron 39,107

Lake Michigan 29,785

Lake St. Clair, Detroit and St.

Clair Rivers

17,050

Lake Superior 13,198

Lake Erie 6,715

Total 105,855

Source: Michigan DNR, Shorelands Inventory, 1973. 
WETLAND ENVIRONMENTS

In Michigan's coastal zone, wetlands occur in four primary environmental settings. These settings are:

1) deltas (e.g., St. Clair River, Whitefish River);

2) shallow shelves (e.g., Wildfowl Bay, Fish Point);

3) sheltered bays and estuaries (e.g., St. Martin Bay, Portage Bay); and 4) barrier/lagoons (e.g., Tobico Marsh, Nayanquing Point).

1. Delta Coasts occur where river sediments are introduced into a lake and coastal currents and wave action are too weak to remove the sediment. As sediments accumulate at the river mouth, deltas expand and the wetland habitat is increased. Such habitats are diverse and support abundant waterfowl, fish, mammals, and reptiles.

2. Shallow Shelves generally support linear coastal wetlands paralleling the shoreline. Such wetlands normally occur between the beach and the 6-foot submarine contour, and are protected from strong wave action. The adjacent land areas (e.g. Saginaw Bay) are most often composed of ancient clay-like plains.

3. Sheltered Bays and Estuaries are relatively shallow areas protected from wave action and strong currents. Wetlands in these areas are often discontinuous and occur in isolated localities and on the leeside of small islands. Examples include the St. Marys River, Lake Michigan and Mismer Bay.

4. Barrier/Lagoon Complexes commonly support dense wetland communities. Wetlands occur behind sand barriers and may be extensive, particularly during lower water periods. During high water periods and storms, the 
unstable barrier may be breached or destroyed, exposing the adjacent wetlands to erosion such as at the Erie State Game Area.

Based on the proposed National Wetland Classification (Cowardin \& Carter, 1975), as updated in April, 1977, the coastal wetland habitats of the state may be tentatively classified within the Lacustrine or Palustrine Ecological System. The Lacustrine System includes all habitats where a wave-formed (beach or barrier) or bedrock shoreline feature forms all or part of the boundary. Where such a topographic or geologic feature is present, the habitats lakeward of it are included in the Lacustrine System regardless of the density of the vegetation.

Figure 2 represents the hierarchy for the Lacustrine Ecological System.

The Palustrine Ecological System includes a wetland where adjacent wave-generated or bedrock features are absent. As now defined, the wetlands associated with this system are not subjected to intensive wave or current action. The hierarchy of this system is presented in Figure 3 .

With regard to Michigan's coastal wetlands, the classes (Figures 2 and 3 ) which appear to be most significant in each system are the "Submergent Bed" and "Emergent Wetland" categories. Dominant emergent aquatics are the sedges (Carex spp), bulrushes (Scirpus spp) and cattails (Typha spp). In terms of a state-wide distribution, based on the 1972 DNR coastal inventory, the following acreages have been determined: sedges, 10,823; bulrush, 42,153; cattail, 30,809; and Potamogeton, 22,338 acres.

Since the Lacustrine and Palustrine Ecological Systems of the pending National Wetland Inventory are associated with landforms, and wave and current conditions, the systems may be related to the environmental settings as outlined above. The Littoral Subsystem 


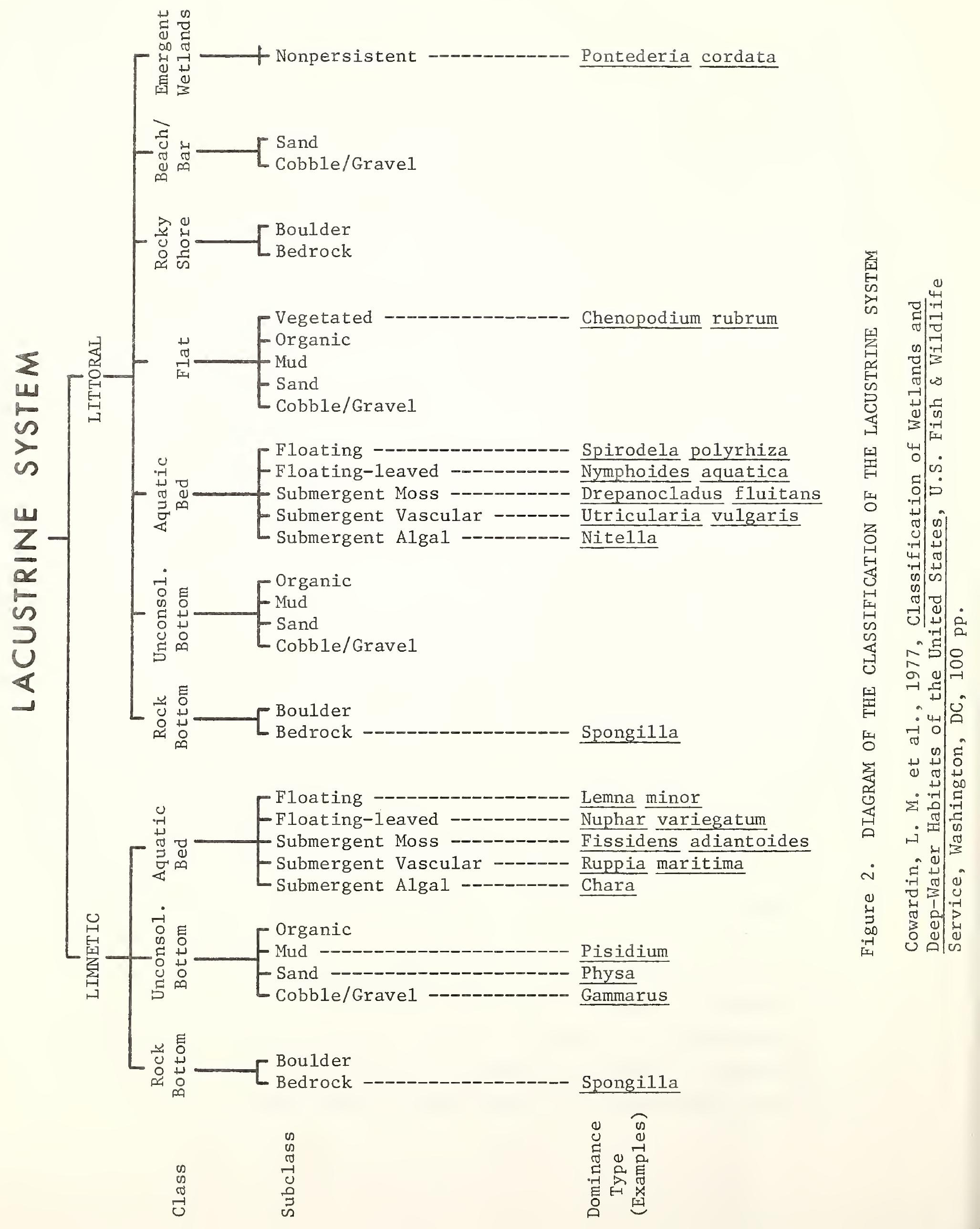




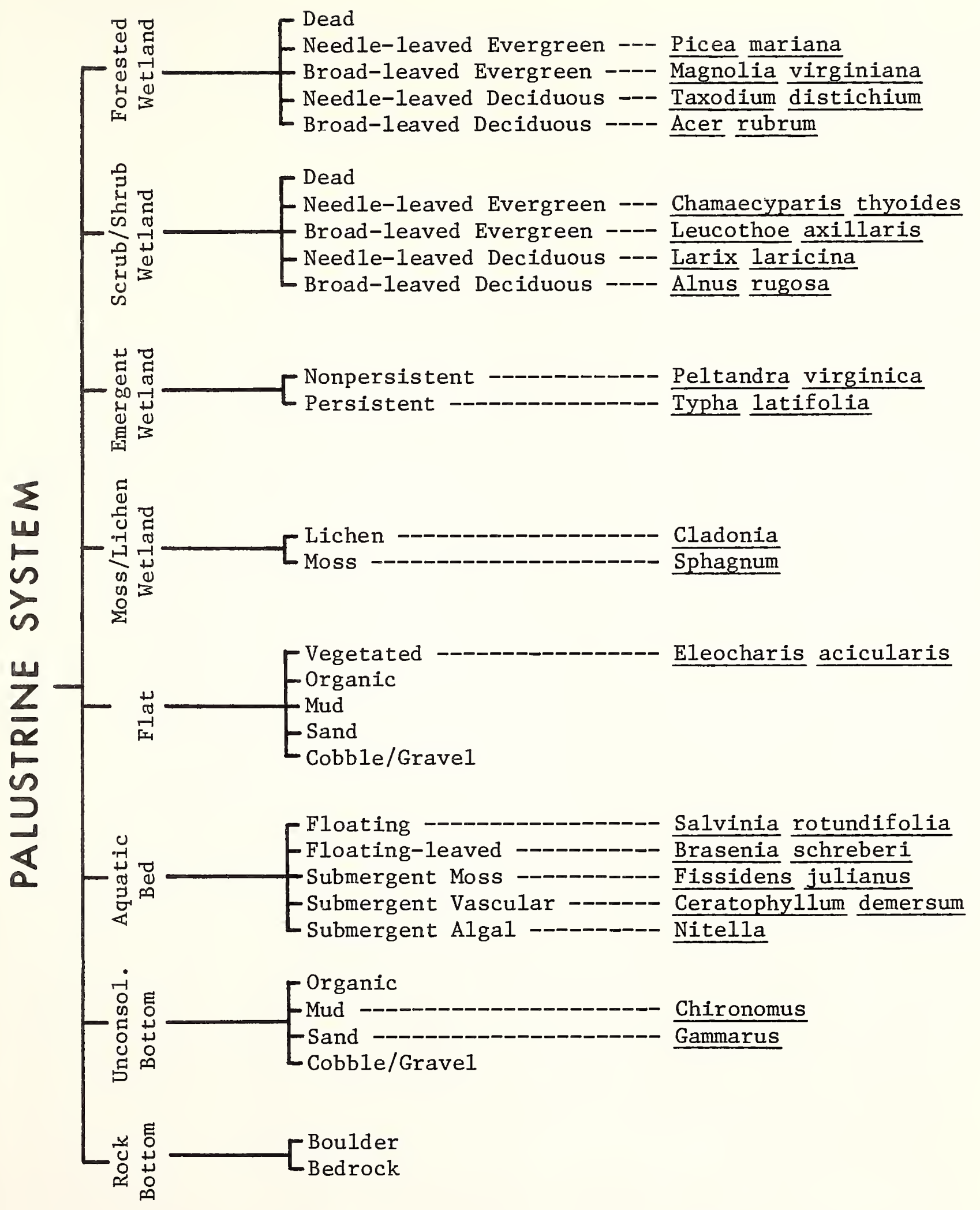

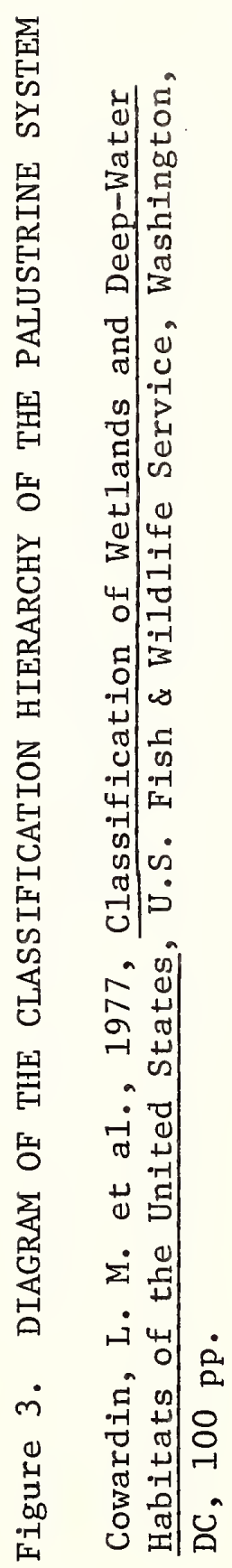

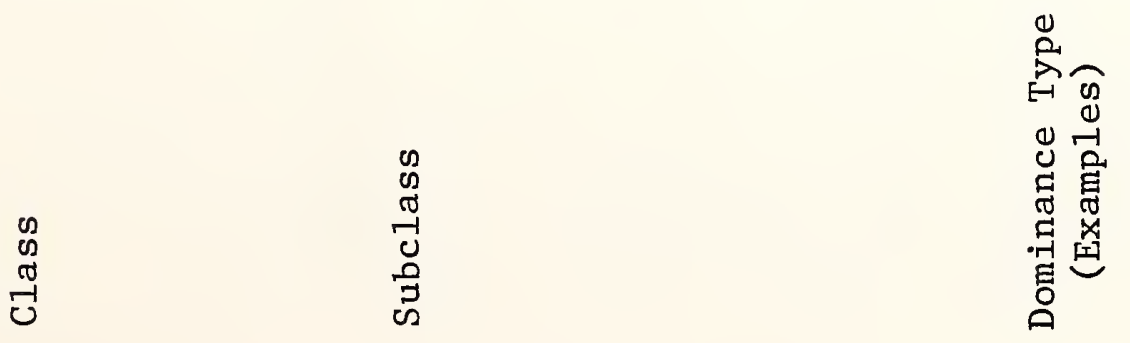


of the Lacustrine System, characterized by beach deposits and current action, is associated with wetlands adjacent to barriers such as coastal Tuscola County and selected areas of Lake St. Clair. Shoals associated with some delta regions (e.g., St. Clair) and shallow shelves (e.g., Fish Point) support aquatic habitats because of weaker currents and lower wave energies, and are generally within the Palustrine (vegetated) System. The sheltered bays and estuaries probably occur in both categories on a statewide scale. If, for example, the head of an embayment is occupied by a beach deposit, the adjacent marsh would be lacustrine. If, however, a protected bay is composed of glacial lake-plain deposit extending out into the lake, the wetland would be categorized as palustrine.

Elsewhere in this report, wetland habitats are identified according to the classification of Shaw and Fredine (1956). Based on that classification, the wetland types which are most significant with regard to coastal Michigan are Types 2, 3, 4, 5, 6, and 7. A comparison of wetland types in Circular 39 by Shaw and Fredine with the proposed National Wetland Classification is presented down to Class/Subclass in Table 3 as determined by Cowardin and Carter (1975). To adequately type the wetland habitats in detail, each wetland must be investigated and mapped on a large scale (e. g., 1:24,000) and additional data on water regime modifiers, water chemistry, soil type (organic or mineral) and special modifiers (e.g., diking, farming, etc.) must be included. WETLAND LOSS

With the use of old maps and modern U.S. Geological Survey topograhic maps a comparison of past and present wetland distributions were made in selected localities. The coastal areas include the four principal environmental settings discussed above and hence a diversity of wetland types were chosen. The coastal areas selected were: 


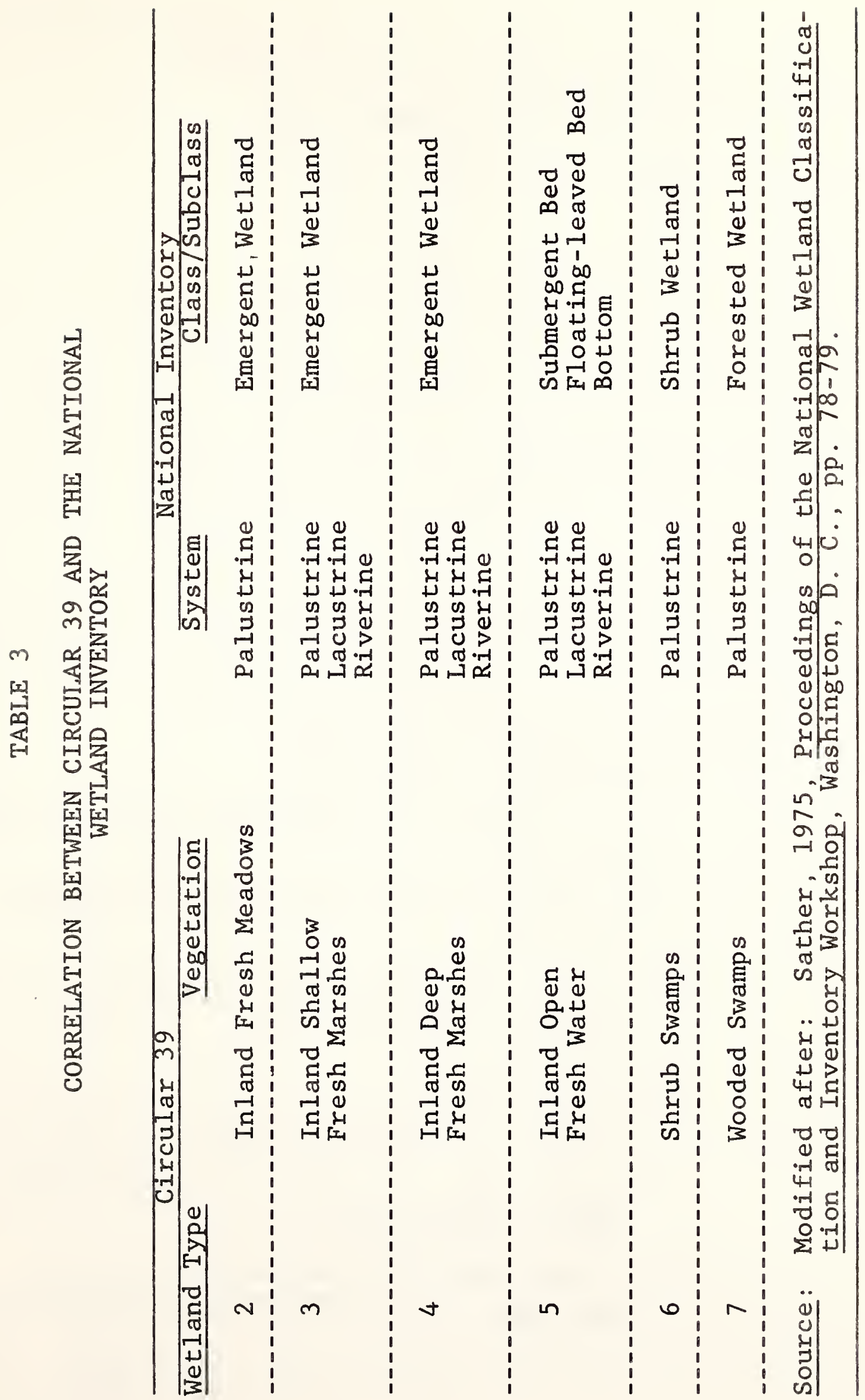


Monroe County to St. Clair County

Huron County to Tuscola County

Bay County to Arenac County

Delta County (Little Bay de Noc)

Eastern Mackinac County

Specifically mapped sites were selected by older map availability and scale. In most cases the premodern wetland vegetation was planimetered from U. S. Army Engineers field survey charts with map scales between $1: 10,000$ to $1: 20,000$. The identical areas were then mapped on modern topographic maps, the majority of which had a scale of 1:24,000, and the wetland acreage difference recorded.

The following charts obtained from the submerged Lands Section of the Michigan Department of National Resources (DNR) were used to determine historical wetland acreages of the areas outlined above:

Lake Erie and Detroit River

J. C. Sanford, 1915, Lower Detroit River, Chart No. 1-1311, U. S. Army Corps of Engineers, $1: 20,000$.

M. M. Patrick, 1916, West End of Lake Erie, Chart No. 1-1312, U. S. Army Corps of Engineers, $1: 20,000$.

F. G. Ray, 1919, Head of Detroit River, Chart No. 1-1392, U. S. Army Corps of Engineers, $1: 10,000$.

Lake St. Clair

J. R. Mayer, 1868, Lake St. Clair, Chart No. 1-412, U. S. Army of Engineers, 1:16,000.

A. Molitor and F. M. Towar, 1868, West Shore of Lake St. Clair, Chart No. 1-413, U. S. Army Corps of Engineers.

W. F. Raynolds and C. B. Comstock, 1873-74, Lake St. Clair, U. S. Army Corps of Engineers, 1:50,000. 
Saginaw Bay

G. C. Meade, 1857, Part of the South East Shore of Saginaw Bay, Chart No. 1-165, U. S. Army Corps of Engineers, 1:16,000.

J. N. Macomb, 1859, South Shore of Saginaw Bay, Chart No. 1-153, U. S. Army Corps of Engineers, $1: 16,000$.

G. C. Meade, 1857, South East Shore of Saginaw Bay, Chart No. 1-166, U. S. Army Corps of Engineers, 1:16,000.

W. H. Hearding, 1856, West Shore of Saginaw Bay, Chart No. 1-154, U S. Army Corps of Engineers, 1:16,000.

G. C. Meade, 1857, West Shore of Saginaw Bay, Chart No. 1-169, U. S. Army Corps of Engineers, 1:16,000.

Little Bay de Noc

W. L. Fisk, 1904-5, Little Bay de Noc, and Approaches to Green Bay, Chart No. 718, U. S. Army Corps of Engineers, 1:40,000.

Les Cheneaux Islands

W. L. Fisk and E. E. Haske11, 1904, Les Cheneaux Islands, Brulee Point to Government Bay, Chart No. 1041, U. S. Army Corps of Engineers, $1: 10,000$.

The best accuracy was obtained with map scales of $1: 10,000$ to $1: 20,000$. Therefore, the planimetering in the lower 3reat Lakes is more representative of the actual wetland acreage because of the larger scale maps. Another reason for more accurate evaluation in the lower peninsula is that the modern topographic maps are more detailed and more recent than in the upper peninsula. Topographic maps available in Bay de Noc area were at a scale of 1:62,500 whereas all other areas were mapped since 1958 at a scale of $1: 24,000$.

Table 4 represents wetlands losses of selected areas planimetered. Considering all areas investigated, there has been a total wetland loss of between 50 to 77 percent. In sum, 41,608 acres of wetland were lost to natural or cultural causes. However, it must also be 
noted that some areas (e.g., Wildfowl Bay), have gained wetland vegetation. In the subsections below, the above areas are tabulated and discussed individually.

\section{TABLE 4}

ACRES OF WETLAND LOSSES IN SELECTED COASTAL AREAS

\begin{tabular}{|c|c|c|c|c|c|c|}
\hline Area & Wetland & Date & Wetland & Date & Loss & $\begin{array}{c}\% \\
\text { Loss } \\
\end{array}$ \\
\hline Lake Erie/Detroit R. & 10,109 & 1916 & 3,871 & $1967-73$ & 6,240 & 61 \\
\hline Lake St. Clair & 18,001 & 1873 & 5,007 & 1973 & 12,999 & 72 \\
\hline Saginaw Bay & 37,437 & 1856 & 17,818 & $1963-73$ & 19,620 & 53 \\
\hline Little Bay de Noc & 2,931 & 1910 & 1,458 & 1958 & 1,473 & 50 \\
\hline Les Cheneaux & 1,652 & 1904 & 374 & 1964 & 1,278 & 77 \\
\hline TOTAL & 70,130 & & 28,522 & & 41,608 & \\
\hline
\end{tabular}

LAKE ERIE/DETROIT RIVER WETLANDS

Table 5 presents, in detail, the coastal wetland losses of Monroe and Wayne Counties. As noted, most of the data are based on years between 1916 and 1973. Most wetland acreage, particularly in coastal Lake Erie, is located in lagoons behind sand barriers. Adjacent to wetlands at Point Mouillee, (i.e., Erie Marshes and the Monroe/La Plaisance area) the land in 1916 was often in pasture suggesting that many fields were already drained or were used extensively during lower water periods. Water levels in Lake Erie during 1915 and 1916 averaged 570.3 feet, slightly below the 1900 to 1976 average of 570.54 feet. Therefore, the wetland distribution represents average conditions. The modern wetland acreage in Table 5 represents conditions approaching record high lake levels (573.30 feet in 1973) which accounts for zero acreage at Humbug Marsh in 1973 and smaller acreages in other sites investigated 
TABLE 5

COASTAL WETLAND LOSSES AND GAINS IN LAKE ERIE AND LOWER DETROIT RIVER

\begin{tabular}{|c|c|c|c|c|c|}
\hline Location & Acres & Date & Acres & Date & Net Change \\
\hline Erie Marshes & 2,285 & 1916 & 1,329 & 1967 & 956 \\
\hline Toledo Beach & 354 & 1916 & 182 & 1967 & 172 \\
\hline Monroe/La Plaisance & 3,666 & 1916 & 408 & 1973 & $-3,258$ \\
\hline Stony Point & 147 & 1916 & 41 & 1973 & -106 \\
\hline Swan Creek & 698 & 1916 & 323 & 1973 & 375 \\
\hline Stony Creek & 55 & 1916 & 10 & 1973 & 45 \\
\hline Pointe Mouillee & 1,376 & 1916 & 1,040 & 1973 & 336 \\
\hline Milleville Beach & 146 & 1916 & 18 & 1973 & 128 \\
\hline $\begin{array}{l}\text { Lower Detroit River } \\
\text { and Marsh Creek }\end{array}$ & 441 & 1916 & 263 & 1973 & 178 \\
\hline Grosse Isle & 541 & 1916 & 63 & 1973 & 656 \\
\hline Humbug & 144 & 1916 & 0 & 1973 & 144 \\
\hline Stony Island & 105 & 1916 & 113 & 1973 & + \\
\hline Celeron Island & 152 & 1916 & 80 & 1973 & 72 \\
\hline TOTAL & 10,110 & & 3,870 & & \\
\hline
\end{tabular}

Significant losses due to construction are known to have occurred throughout the western Lake Erie shoreline. The development of the city of Monroe has had a particularly significant impact on the coastal wetlands and only 408 acres remain physically unaltered today. A comparison of Figures 4 and 5 reveals that filling by public, as well as private, concerns are responsible for losses. A comparison of the Woodtick Peninsula (Figures 6 and 7) demonstrates that losses have occurred in areas of less industrial/commercial pressure.

LAKE ST. CLAIR WETLANDS

The wetlands of Lake St. Clair are nationally known for their waterfowl and fish habitats. In 1868-1873 
FIGURE 4--Distribution of Raisin River Wetlands in 1915 (after Jaworski and Raphael, 1976).

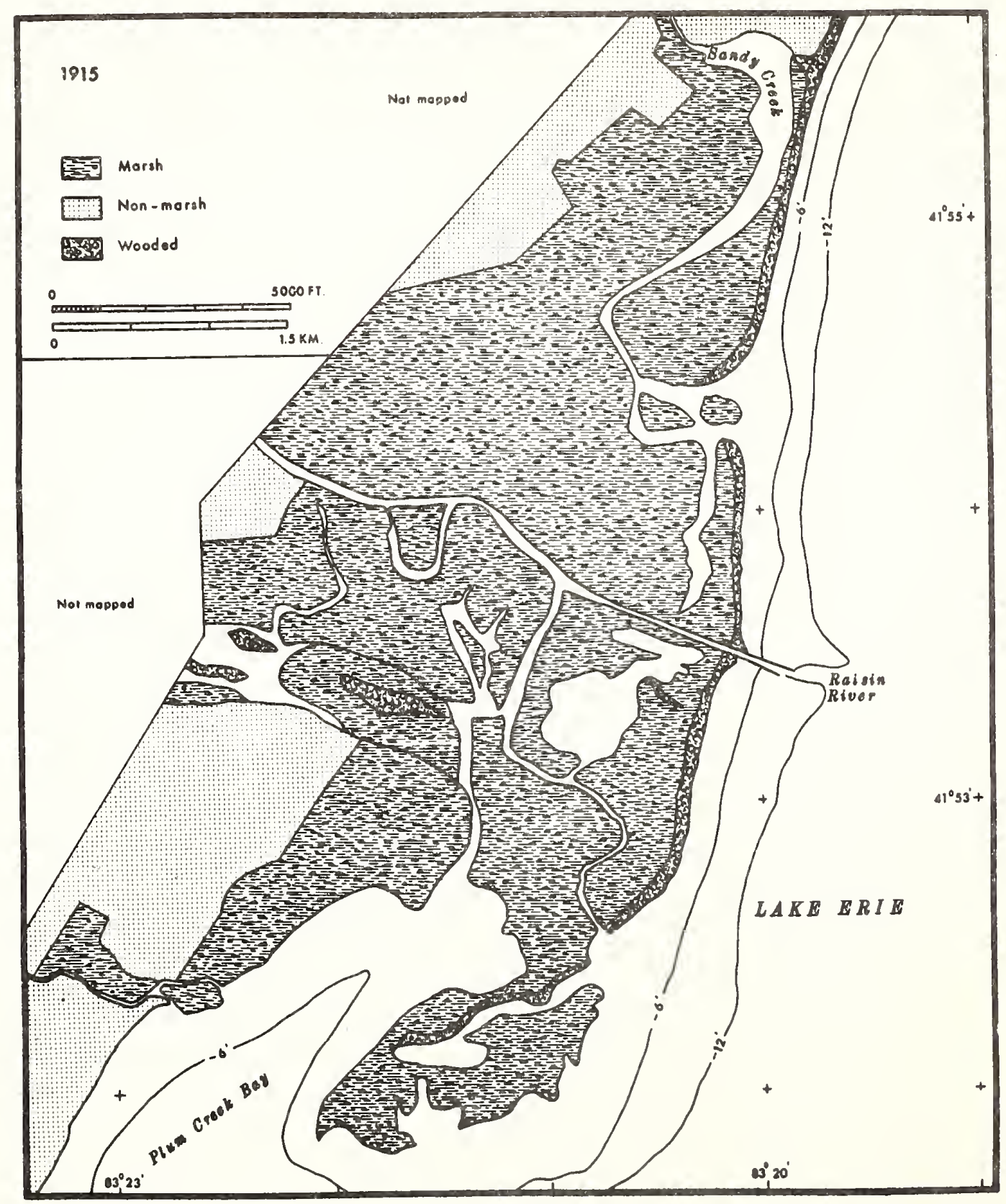


FIGURE 5--Distribution of Raisin River Wetlands in 1974 (after Jaworski and Raphael, 1976).

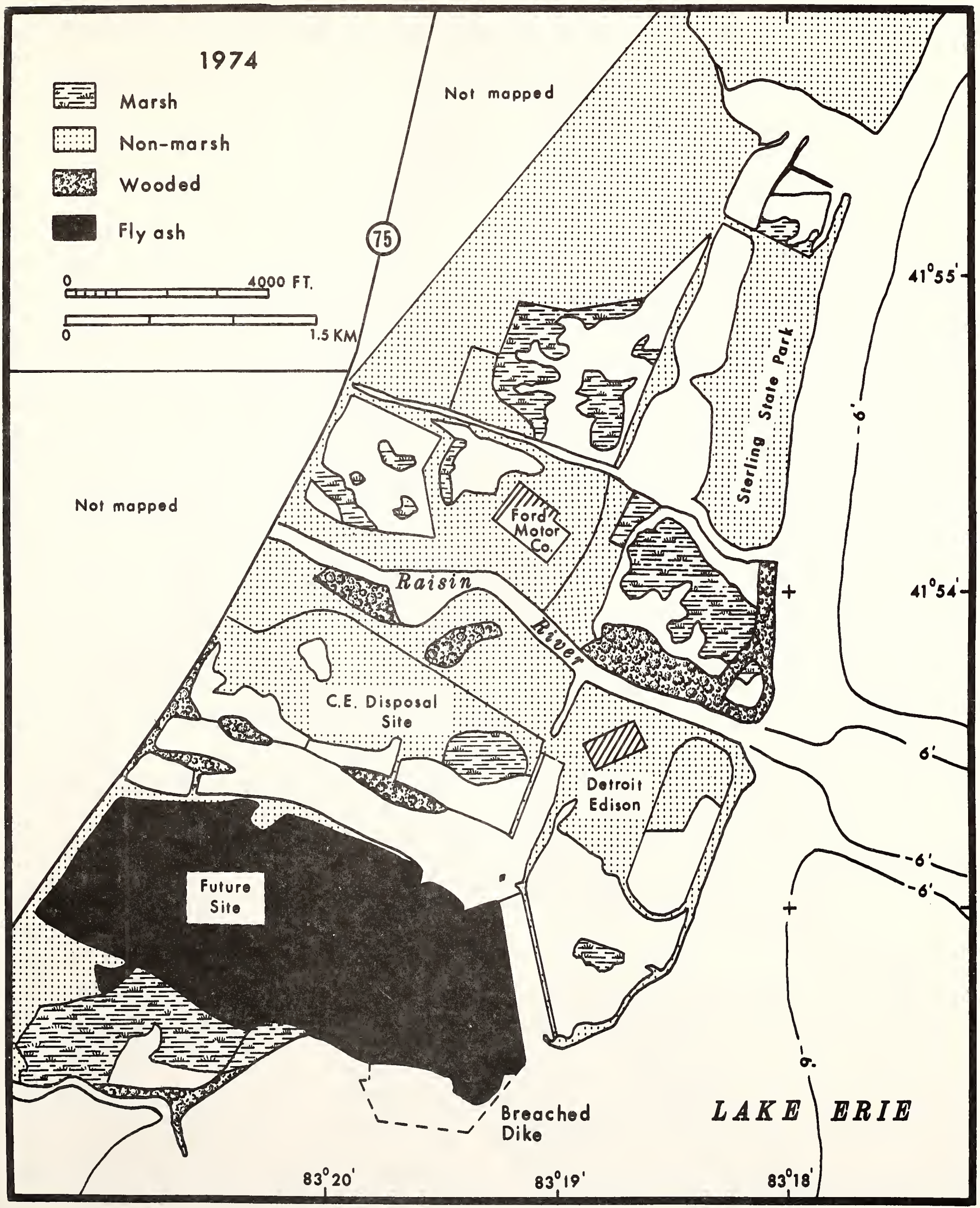


FIGURE 6--Coastal Wetlands of Southern Monroe County in 1901 (after Jaworski and Raphael, 1976).

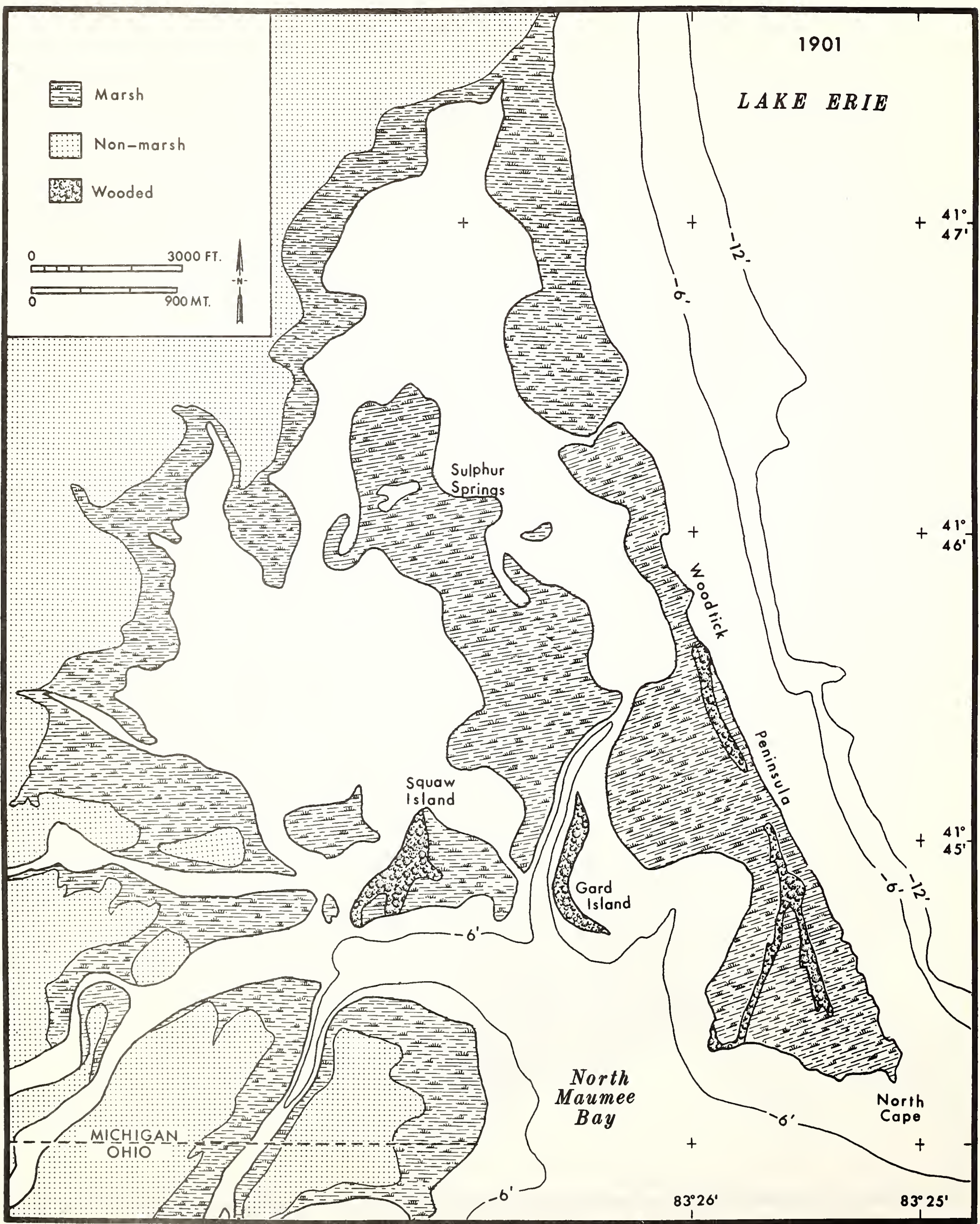


FIGURE 7--Coastal Wetlands of Southern Monroe County in 1974 (after Jaworski and Raphael, 1976).

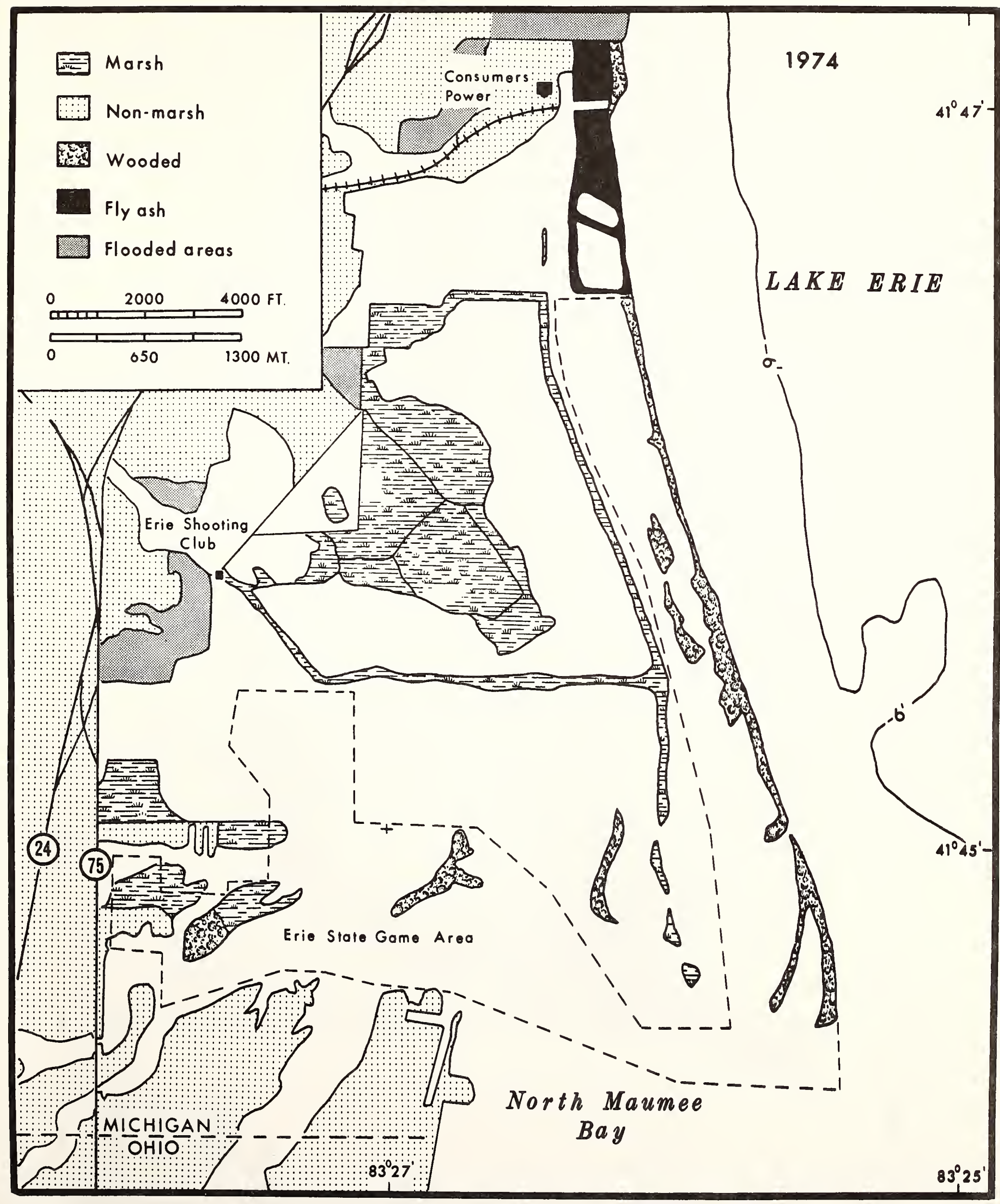


the U. S. portion of Lake St. Clair supported 18,000 acres of wetland vegetation (Table 6). By 1973 this habitat dwindled to 5,000 acres. Significant losses not only occurred on the St. Clair delta and St. Johns Marsh, but on the entire margin of the lake as well. Gaukler Point (St. Clair Shores) supported 462 acres of wetlands and the Clinton River had over 3200 acres of wetlands at its mouth.

TABLE 6

WETLAND LOSSES IN LAKE ST. CLAIR

\begin{tabular}{|c|c|c|c|c|}
\hline Location & Acres & Date & Acres in 1973 & Losses \\
\hline St. Clair Flats & 13,547 & 1873 & 4,403 & 9,144 \\
\hline Swan Creek & 185 & 1868 & 4 & 181 \\
\hline Marsac Point & 149 & 1868 & 5 & 144 \\
\hline New Baltimore & 52 & 1868 & 0 & 52 \\
\hline Salt River & 400 & 1868 & 44 & 356 \\
\hline Clinton River & 3,206 & 1873 & 546 & 2,660 \\
\hline Gaukler Point & 462 & 1873 & 0 & 462 \\
\hline TOTAL & 18,001 & & 5,002 & 12,999 \\
\hline
\end{tabular}

Some coastal areas, particularly north of the Clinton River, appear to have been converted to agriculture by the 1860's suggesting that prior to that time the wetlands were more extensive. In 1973, a total of 16,220 acres of coast were occupied by residential, recreational (i.e., marinas), and commercial uses, as compared to the area in 1873 (Figures 8 and 9). Attempts in recent months to expand residential development in the Clinton marshes have been stopped by the courts (U.S. Vs. Riverside Bayview Homes, Inc. and Allied Aggregate Transportation Company). 


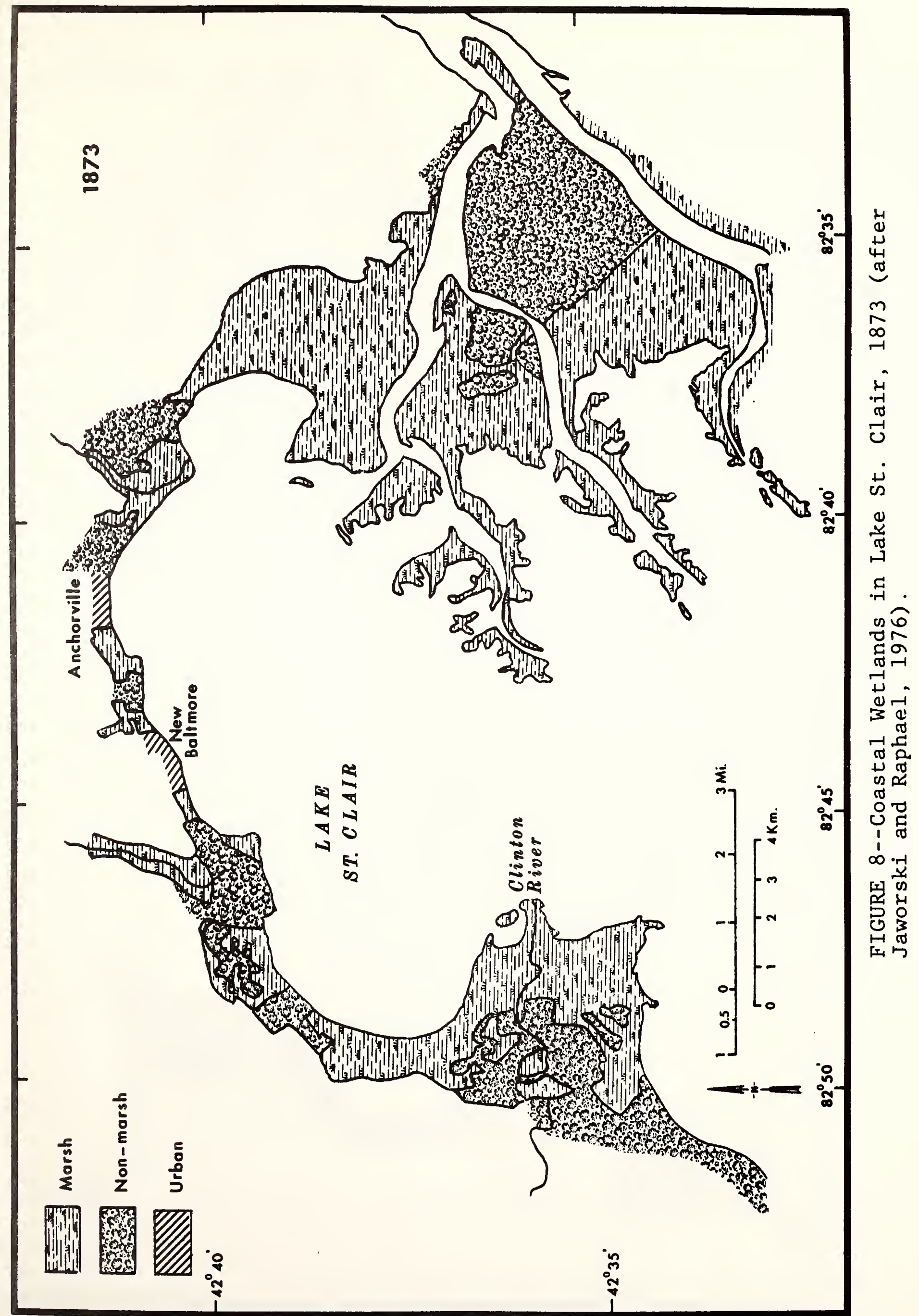




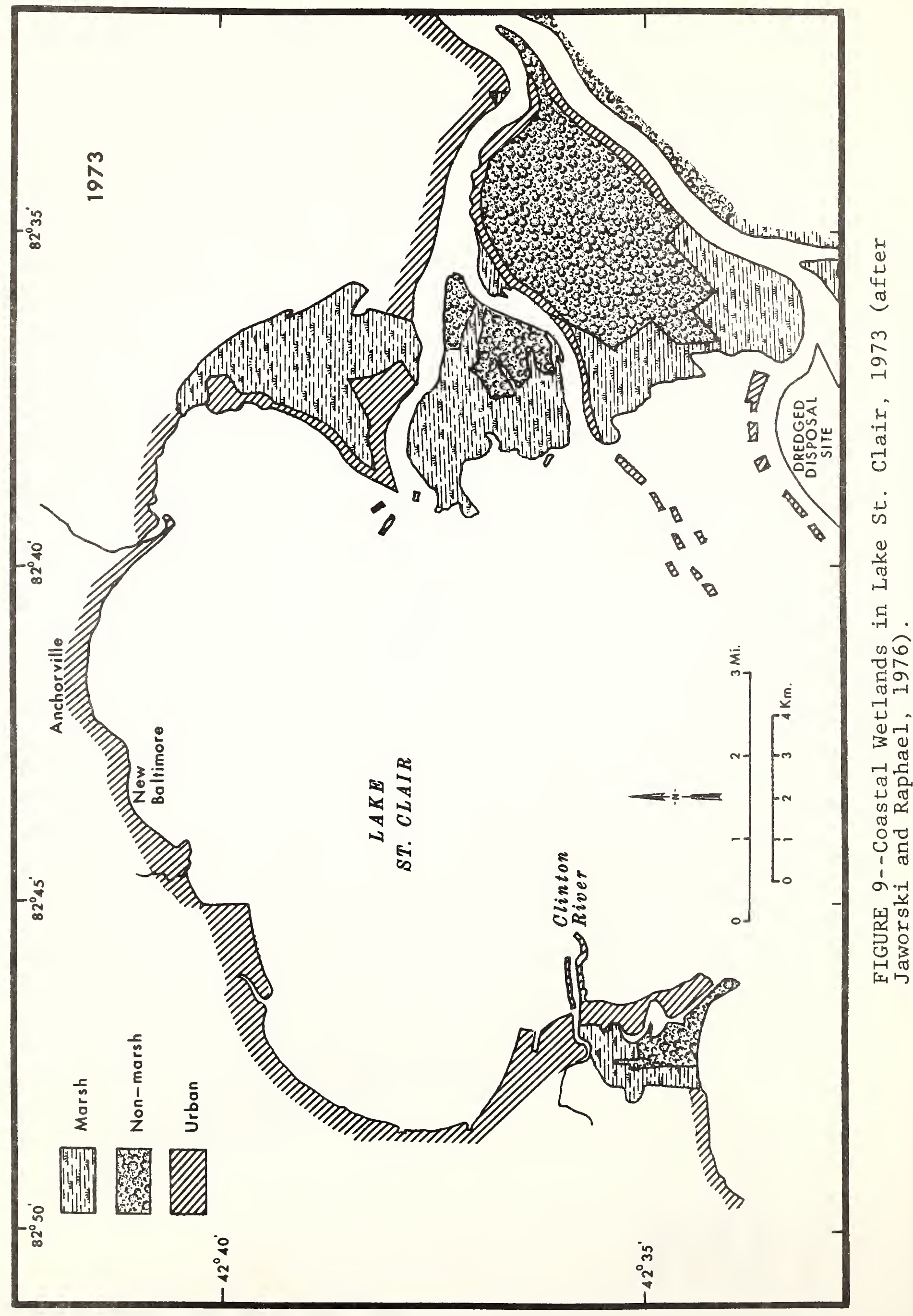


SAGINAW BAY WETLANDS

Navigation charts published in 1857 were used to map wetland vegetation extending from Sand Point southwestward to Garner Road in Tuscola County. Additional charts extend from one-half mile east of Knight Road in Bay County northward to Point Au Gres. The wetland south of Gordon Road in Arenac County was included as part of the Au Gres wetland.

The wetland vegetation as planimetered on the 1857 charts totalled 37,437 acres. By 1963-73 these wetlands totalled 17,816 acres (Figures 10 and 11). As noted in Table 7 , increases in wetlands were recorded in the offshore islands of the Wildfowl Bay Wildlife Area, the offshore marshes of Huron and Tuscola Counties, particularly southwest of Sebewaing and the wetlands of $\mathrm{Au}$ Gres. Elsewhere, wetland acreage declined.

Permanent losses have occurred in Huron/Bay Counties and in the Kawkawlin/Saginaw River area. On the 1857 charts a wetland paralleled the shoreline and extended inland 7,000 feet. Based on U. S. Geological Survey topographical maps of this area (Fish Point Quad., 1973) the elevations here are less than 585 feet; an elevation nearly equal to that of the modern shoreline. The area has been drained for agriculture and the fields have been tiled. In 1857, the wetland landward (south) of the coastal barrier occupied 11,701 acres. By the 1960's, the entire wetland had been drained.

A wetland separated from Saginaw Bay by a coastal barrier extended from the Kawkawlin River southeastward beyond the Saginaw River to the Quanicassee Wildlife Area. The wetland lakeward of the 585 foot contour covered 3,313 acres in 1857. Due to draining and urban and commerical growth, this marsh was reduced to 721 acres by 1973. 


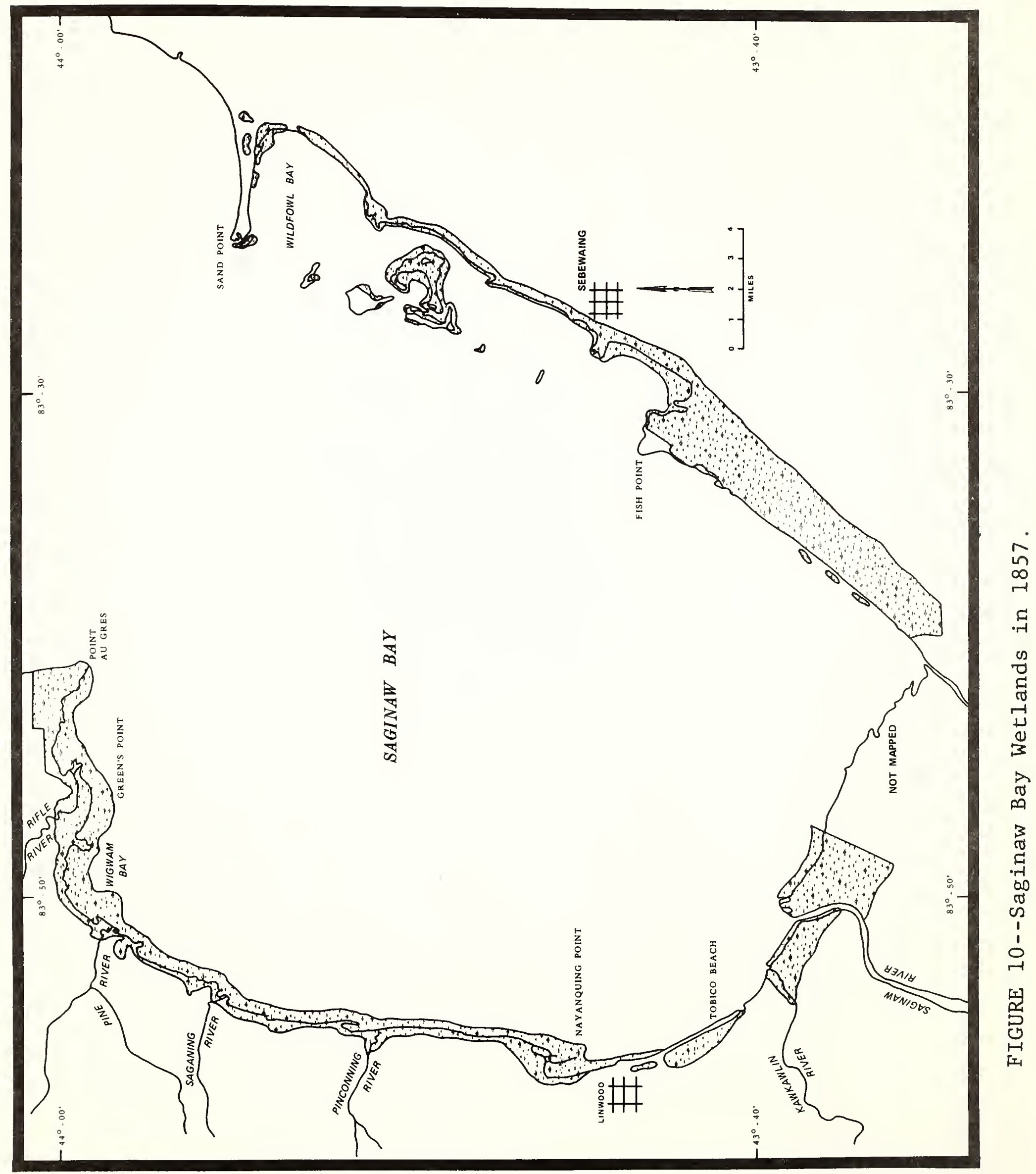




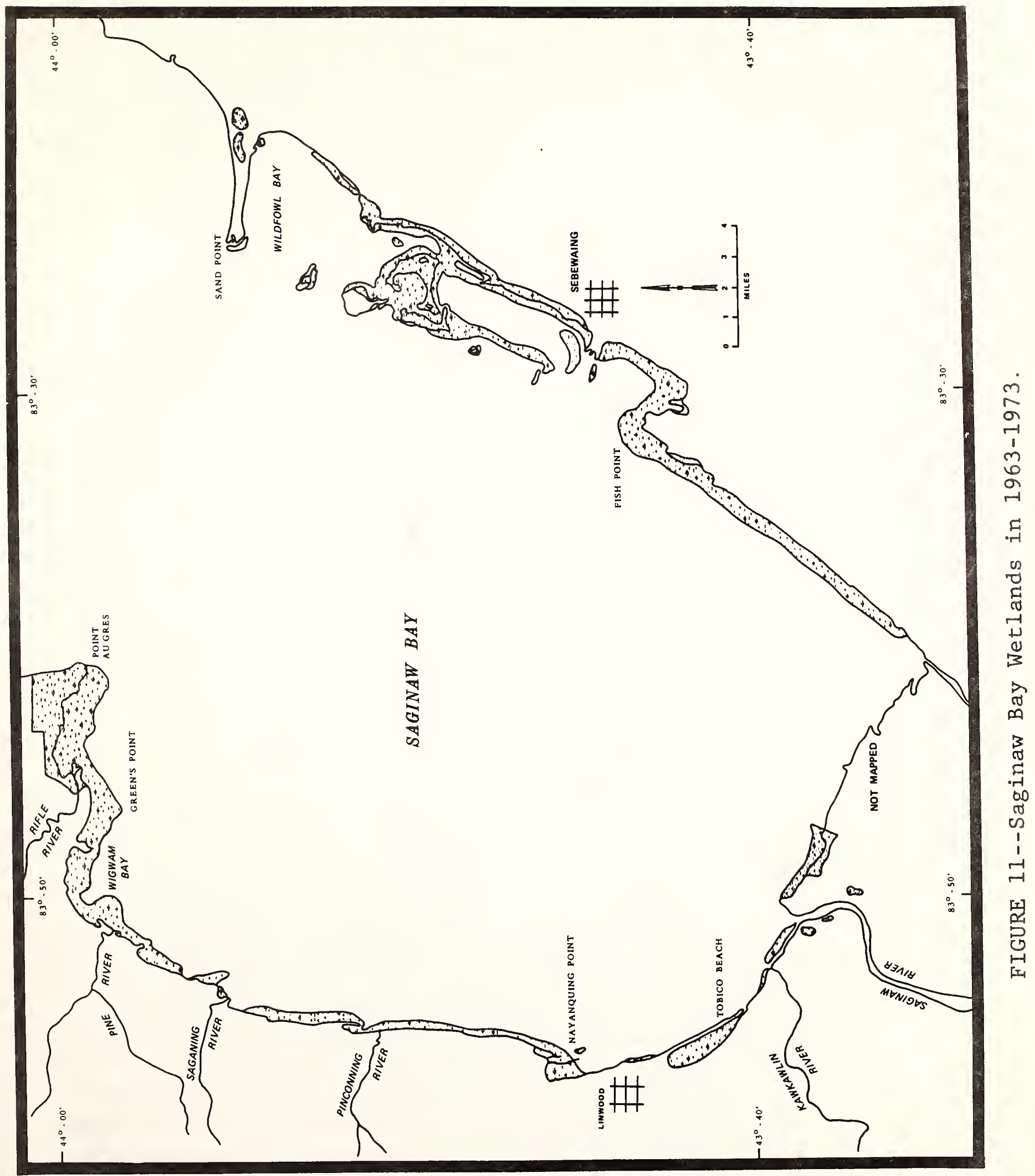


TABLE 7

COASTAL WETLAND LOSSES AND GAINS IN SAGINAW BAY

\begin{tabular}{|c|c|c|c|c|}
\hline Location & Acres in 1857 & Acres & Date & $\begin{array}{c}\text { Net } \\
\text { Change } \\
\end{array}$ \\
\hline $\begin{array}{l}\text { Wildfowl Bay Wildlife Area } \\
\text { (Offshore Islands) }\end{array}$ & 1,578 & 3,076 & 1970 & $+1,498$ \\
\hline $\begin{array}{l}\text { Sand Point to Fish Point } \\
\text { Wildlife Area to Garner } \\
\text { Road (Quanacassee Wildlife } \\
\text { Area) }\end{array}$ & & & & \\
\hline $\begin{array}{l}\text { a) Lakeward of barrier } \\
\text { b) Landward of barrier }\end{array}$ & $\begin{array}{l}2,281 \\
9,420 \\
\end{array}$ & $\begin{array}{r}6,903 \\
0 \\
\end{array}$ & $\begin{array}{l}1963-73 \\
1963-73\end{array}$ & \\
\hline SUBTOTAL & 11,701 & 6,903 & & $-4,798$ \\
\hline $\begin{array}{l}\text { Saginaw River/Kawkawlin } \\
\text { Area ( } \frac{1}{2} \text { mile east of } \\
\text { Knight Road) }\end{array}$ & 3,313 & 721 & 1973 & $-2,592$ \\
\hline Tobico Marsh & 1,040 & 599 & 1973 & -441 \\
\hline Linwood & 352 & 60 & 1973 & $-\quad 292$ \\
\hline Nayanquing Point & 2,023 & 952 & 1973 & $-1,363$ \\
\hline Pinconning River Reach & 1,765 & 689 & 1973 & $-1,076$ \\
\hline $\begin{array}{l}\text { Saganing River } \\
\text { a) Lakeward } \\
\text { b) Landward }\end{array}$ & $\begin{array}{r}1,383 \\
786\end{array}$ & $\begin{array}{r}489 \\
0\end{array}$ & $\begin{array}{l}1973 \\
1973\end{array}$ & $\begin{array}{l}-1,970 \\
-\quad 786\end{array}$ \\
\hline Pine River & 4,913 & 424 & 1967 & $-4,489$ \\
\hline $\begin{array}{l}\text { Rifle River (Wigwam Bay) } \\
\text { (To Greens Point) }\end{array}$ & 5,620 & 586 & 1967 & $-5,034$ \\
\hline $\begin{array}{l}\text { Au Gres (Greens Point to } \\
\text { Gordon Road) }\end{array}$ & 2,963 & 3,318 & 1966 & +355 \\
\hline TOTAL & 37,437 & 17,817 & & \\
\hline
\end{tabular}

Reduction of wetland habitat at Tobico Marsh attributed to residential encroachment and erosion of the coastal.barrier. Dwellings occupy the entire barrier and additional filling appears to have occurred especially at Tobico Beach. With the exception of Au Gres, the wetlands north of Tobico have deteriorated. A 352 acre wetland just south of Linwood has been drained and only 60 acres remain. Most of the remaining wetland acreage with the 
exception of Nayanquing Point and Au Gres, occurs on shallow shelves in Saginaw Bay.

WETLAND LOSSES IN THE LES CHENEAUX ISLANDS

The wetland losses for a portion of the Les

Cheneaux Islands and the mainland of southern Mackinac County were determined. The area investigated extends from Government Island westward to Brulee Point (Figures 12 and 13). The lakeward limit of this site was latitude $57^{\circ} 29^{\prime}$ north and included the northern half of Marquette Island. Many of the wetlands with the exception of Mismer Bay, Hessel Bay, and Mackinac Bay appear to be offshore or within the Palustrine Ecological System. Table 8 represents wetland losses between 1904 and 1964 .

The wetlands of the Les Cheneaux Islands are scattered and occupy embayments protected from strong wave action. The largest intact wetland acreage is in northern Mismer Bay at the mouths of the Steele and Law Creeks (140 acres). The Les Cheneaux area is unique because of the specific areas of wetland loss. Based on the 1904 survey approximately one-half of the wetland acreage was situated between the shoreline and the minus 6-foot submarine contour. During the summer of 1902 and 1903 when the mapping was probably done, Lake Michigan was at 578.7 feet above sea level. In the 2-year period from 1962-63, lake level ranged from 575.8 to 577.9 feet; considerably lower than the 1902-1903 levels. Thus, despite the lower levels of the 1960's, lacustrine wetland loss had occurred. Human disturbance due to agricultural and urban encroachment appears to have been minimal in the areas examined. The only exception is in Mackinac Bay east of Hessel, where artificial drains have been excavated, probably, for agricultural expansion. 


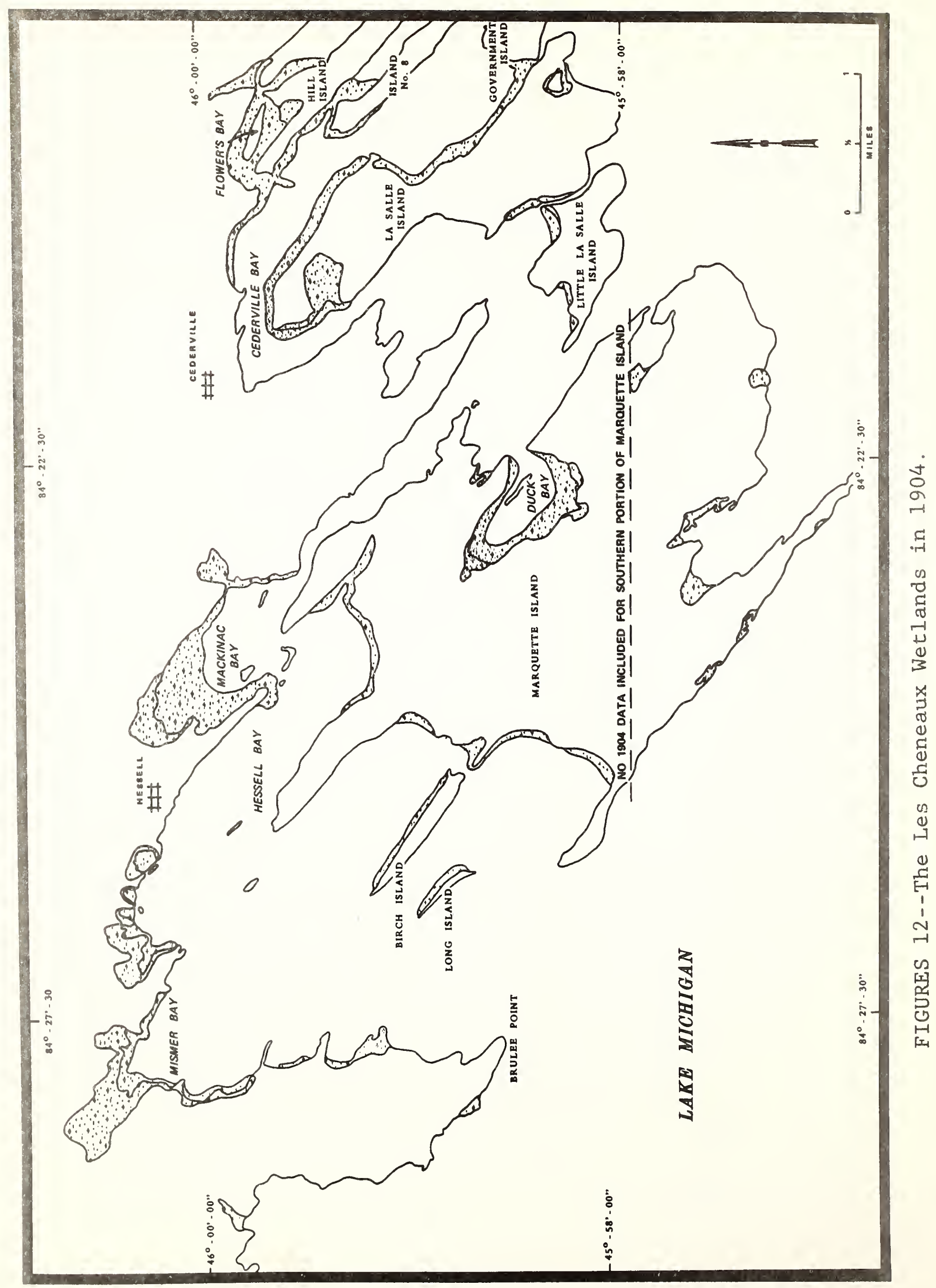




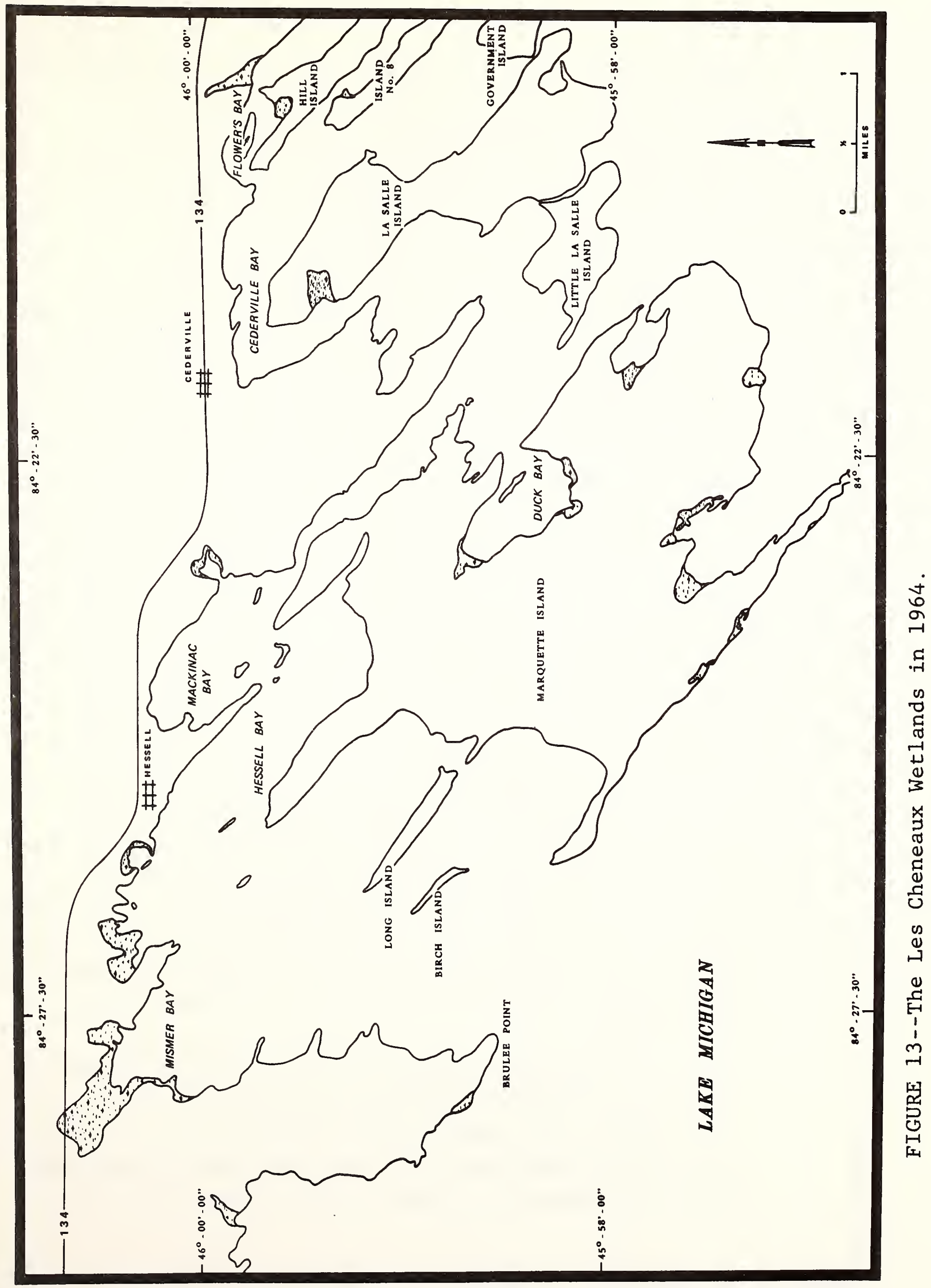


TABLE 8

WETLAND LOSSES IN THE LES CHENEAUX ISLANDS

\begin{tabular}{|c|c|c|c|}
\hline Location & 1904 Acreage & 1964 Acreage & Loss \\
\hline Mismer Bay & 232 & 140 & -92 \\
\hline Hessel Bay & 128 & 51 & -77 \\
\hline Mackinac Bay & 276 & 29 & -247 \\
\hline Sheppard Bay & 62 & 0 & -62 \\
\hline Cedarville Bay & 100 & 0 & -100 \\
\hline Flowers Bay & 133 & 24 & -109 \\
\hline $\begin{array}{l}\text { Hill Island and } \\
\text { Channel }\end{array}$ & 93 & 20 & -73 \\
\hline Island Number 8 & 16 & 5 & -11 \\
\hline $\begin{array}{l}\text { La Salle and Little } \\
\text { La Salle Islands }\end{array}$ & 267 & 56 & -211 \\
\hline $\begin{array}{l}\text { Marquette Island } \\
\text { (Northern half) }\end{array}$ & 298 & 49 & -249 \\
\hline Long Island & 15 & 0 & -15 \\
\hline Birch Island & 15 & 0 & -15 \\
\hline Moscoe Channel & 17 & 0 & -17 \\
\hline TOTAL & 1,652 & 374 & \\
\hline
\end{tabular}

LITTLE BAY DE NOC WETLANDS

The wetlands of Little Bay de Noc were planimetered using 1910 navigation charts at a scale of $1: 40,000$. With topographic maps at a scale of $1: 62,500$, the 1958 wetland acreages were determined (Figures 14 and 15). Based on these data, approximately 50 percent of the wetlands were lost (Table 9). The 1910 acreage totalled 2,930 acres. By 1958 these wetlands were reduced to 1,457 acres.

The level of Lake Michigan in 1908-10 averaged 570.45 feet whereas the average between 1956-58 was 572.65 feet. The higher levels of the mid-1950's suggests that some wetlands may have been lost due to high water. North of Gladstone, a delta has been deposited at the 


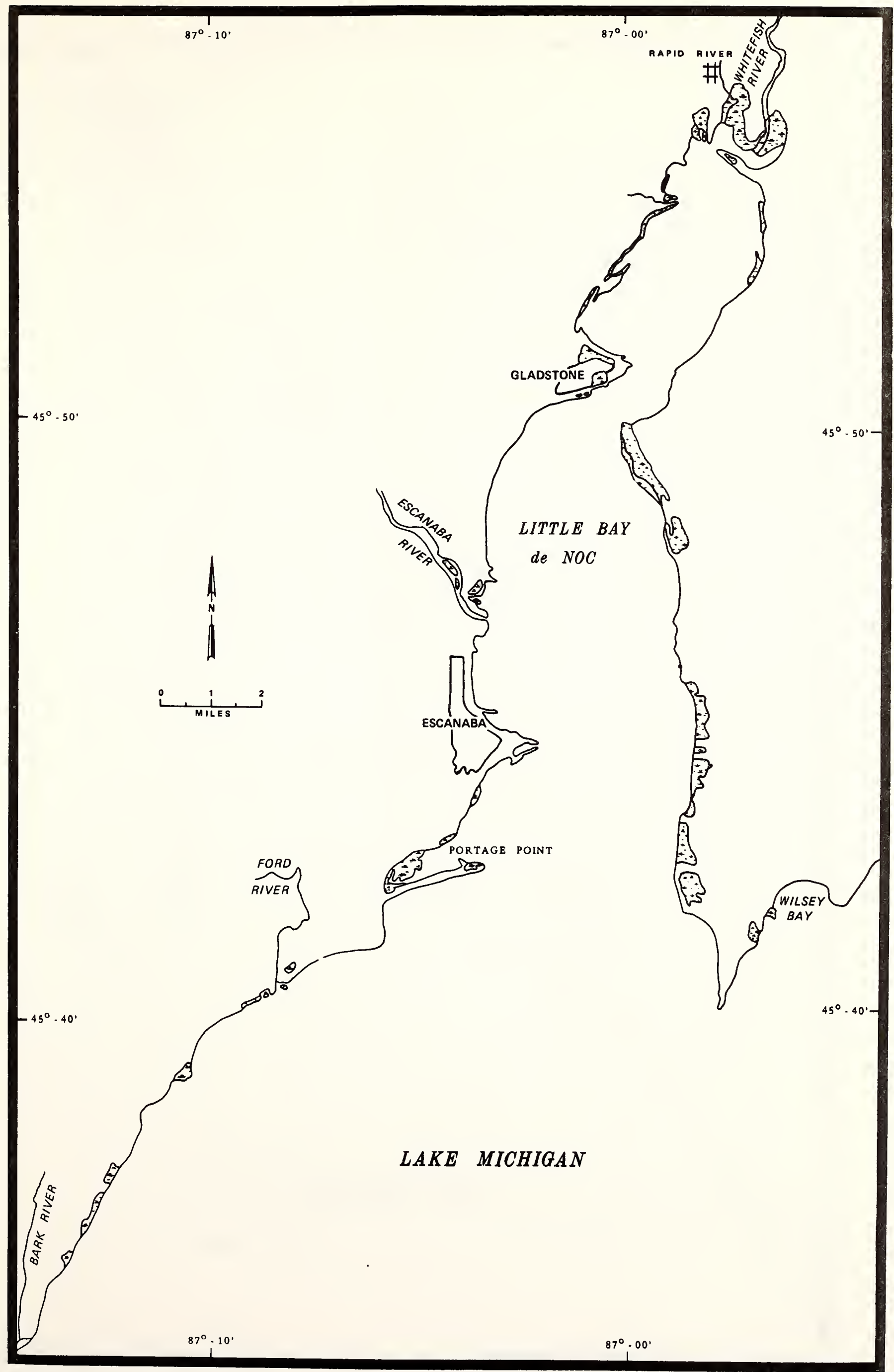

FIGURE 14--The Little Bay de Noc Wetlands in 1910. 


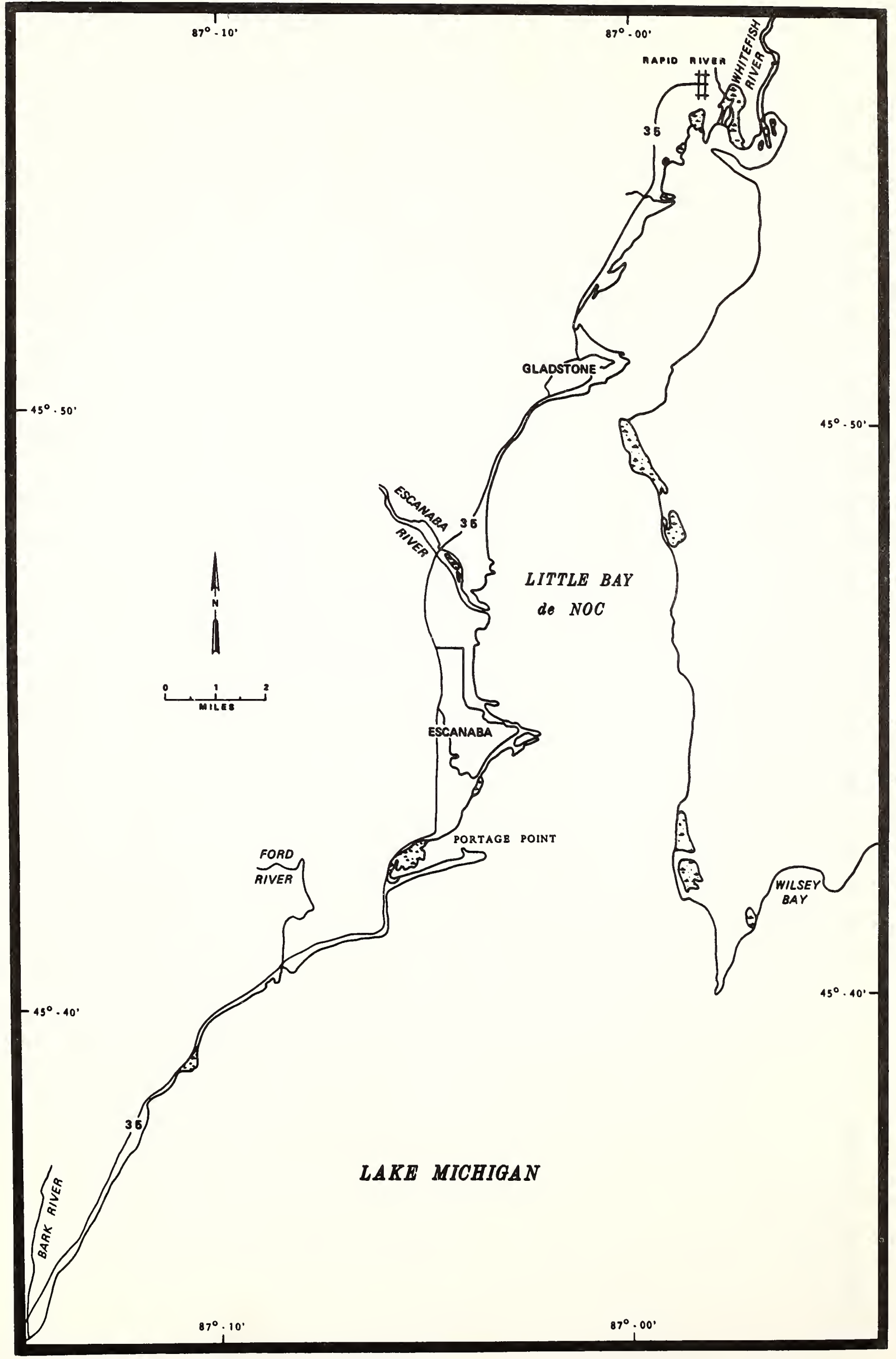

FIGURE 15--The Little Bay de Noc Wetlands in 1958. 
TABLE 9

WETLAND LOSSES IN LITTLE BAY DE NOC 1910-1958

\begin{tabular}{|c|c|c|c|}
\hline Location & Acreage & 1958 Acreage & $\underline{\text { Loss }}$ \\
\hline Whitefish River Delta & 633 & 486 & -147 \\
\hline $\begin{array}{l}\text { Escanaba River to } \\
\text { Portage Point }\end{array}$ & 480 & 362 & 118 \\
\hline Ford River Delta & 148 & 62 & 86 \\
\hline $\begin{array}{l}\text { Shoreline from Bark } \\
\text { River to and including } \\
\text { Wilsey Bay }\end{array}$ & 1,670 & 548 & $-1,122$ \\
\hline TOTAL & 2,931 & 1,458 & \\
\hline
\end{tabular}

mouth of the Whitefish River. The 1958 map suggests that 147 acres of this deltaic wetland have been drained for agricultural purposes. Other losses, such as in the vicinity of Escanaba, appear to be associated with urban and commercial expansion. DISCUSSION

Based upon the sites investigated, it may be concluded that over 41,000 acres of coastal wetlands have been lost (Table 4). The wetland acreage differences between two time frames are due to natural causes such as flooding and/or erosion or to cultural modifications such as urban/residential growth. A third possibility is a combination of natural and cultural impacts. Table 10 may be premature without more intensive on-site investigation; however, based on this investigation, some basic insights may be presented. As noted historically, at all investigated sites several factors may be related to wetland losses. With the exception of coastal flooding, all factors were determined from the comparative map study and the available literature. The "coastal flooding" category was obtained from The National Shoreline Study (U. S. Army, 1971). 
TABLE 10

PROBABLE CAUSES OF WETLAND LOSSES IN SELECTED AREAS

\begin{tabular}{lcl}
\hline $\begin{array}{l}\text { Wetlands } \\
\text { Lake Erie and } \\
\text { Detroit River }\end{array}$ & $\frac{\text { Acres Lost }}{6,240}$ & $\begin{array}{l}\text { Probable Cause } \\
\text { Draining, Commercial/ } \\
\text { Residential Growth, } \\
\text { Erosion, Flooding. }\end{array}$ \\
Saginaw Bay & 12,999 & $\begin{array}{l}\text { Draining, Local Commer- } \\
\text { cial/Urban Expansion, } \\
\text { Coastal Flooding. } \\
\text { Draining, Coastal }\end{array}$ \\
Bay de Noc & 19,620 & $\begin{array}{l}\text { Erosion, Local Comer- } \\
\text { cial/Residential } \\
\text { Growth. } \\
\text { Coastal Flooding, Local } \\
\text { Draining, Local Urban } \\
\text { Expansion. } \\
\text { Erosion, Local Drain- } \\
\text { ing. }\end{array}$ \\
1,473 & 1,278 & \\
\hline
\end{tabular}

Due to natural conditions, wetland losses have been most severe over the years where coastal sand barriers have been destroyed by erosion, and by high water levels. Once the coastal barrier is eroded, the adjacent wetlands are exposed to wave action. At the mouth of the Huron River, for example, between 1940 and 1972, some 900 acres of marsh have been lost to Lake Erie due to the destruction of the coastal barrier lakeward of Pointe Mouillee (Se1lman, et a1., 1974, p. 21).

The impact of recent high lake levels on deltas, shallow offshore shelves, and sheltered bays is poorly known. However, some preliminary investigations suggest that as lake levels rise and fall the wetlands are temporarily drowned or shift landward or lakeward with the changing levels. In the St. Clair delta, a vegetation transect monitored between 1972 and 1974 documents this 
horizontal displacement (Jaworski and Raphael, 1976, p. 306-307). Aerial photograph studies comparing the St. Johns Marsh in 1938 and 1974 revealed that the wetland acreage increased despite the higher lake levels (Lowe, et al., 1976, p. 28-30).

In coastal Lake Michigan, wetlands are located in drowned estuaries and protected from the lake by coastal sand dunes. In most cases these estuarine lakes are connected to Lake Michigan by rivers and hence are affected by Great Lakes water level oscillations. The impact of the lake level on the wetland communities appears to be similar to that in other bays. In Lake Macatawa near Holland, as lake level rose in the early 1970's, the cattail marsh became increasingly less dense. By 1975 only a cattail fringe occupied the north shore of the lake (Greij, 1976, p. 3).

Conversely, at the Les Cheneaux area permanent loss of wetland appears to be associated with changing lake level since human disturbance was minimal. In an unpublished manuscript, Core (1949) concludes that there has been a significant loss of aquatic vegetation in western Lake Erie. Possible causes for the losses as suggested by the author included changing lake levels, water movements, carp feeding habits and agricultural activity.

Wetland losses are more severe where cultural modifications have occurred. These modifications include dredging and filling, draining for agricultural purposes and commercial/residential expansion (e.g., see Kaatz, 1955). In most cases, such activities have a permanent effect and occur in all types of coastal wetlands identified. Also, such changes may alter the water quality of adjacent wetlands and hence degrade wetland habitats (see for example, Regier and Hartman, 1973). 
As rural migration into the Great Lakes basin occurred in the early 19 th century, wetlands were drained and cleared for agriculture. The wet prairie zone from Port Clinton, Ohio to Detroit, where Spartina was abundant was permanently lost (Bednarik, 1975, p. 1). This region, known as the Great Black Swamp, occupied a 40-mile by 120-mile area in the $1850^{\prime} \mathrm{s}$. Between 1854 and 1900 the wetland was drained for agricultural purposes (Langlois, 1954, p. 22). By 1950, 1,800 miles of drainage ditches were constructed in the region. Based on 1856 field survey charts, similar losses have occurred in Huron and Tuscola counties. The Detroit River is a highly industrialized/commercial area. On the Michigan side of the river, the shoreline was colonized by at least 3,000 acres of wetland in 1796 (Kreisman, et al., 1976, p. 13). By 1967 , only 390 acres of wetland remained and that is of questionable quality.

Pact loss rates of coastal wetlands can be determined if more time periods were included. As noted by Panzner (1955, p. 10), the removal of water from wetlands in Michigan through agricultural drainage occurred, to a large degree, prior to 1930. Also, between 1934 and 1941, the Works Progress Administration and Federal Relief Agencies carried out drainage projects in Michigan designed for malaria control (ibid., p. 10). Miller (1954) identified areas in the state where past drainage had occurred and areas of probable future drainage of wetlands. According to his report, areas where industrial and urban development destroyed high-quality wetland habitat included St. Clair, Macomb, Wayne, and Monroe Counties as well as Bay County. According to Miller, the other coastal counties of southeastern Michigan (Tuscola, Huron and Sanilac) were severely damaged in the past, but future damage was anticipated to be limited. The remaining coastal counties of the state, according to that report, 
had limited loss in the past and future wetland loss was also to have been limited as weil.

Wetland losses are not restricted to high population centers in southeastern Michigan. Wetland losses have been identified elsewhere. Between 1857 and 1973, a 352-acre marsh south of Linwocd was reduced to 60 acres. Between 1910 and 1958 the Whitefish River delta (in the Upper Peninsula) was reduced from 630 acres to 486 acres. PROSPECTS

Significant wetland losses have occurred in coastal Michigan due to natural and cultural factors. In some instances (e.g., Lake St. Clair and Saginaw Bay) flooding and high lake levels may temporarily drown coastal wetlands. However, as water levels fall, it may be anticipated that such habitats will regenerate. Conversely, cultural impacts are irreversible. Draining, commercial growth and residential expansion permanently destroy the wetland habitat.

Table 11 summarizes shoreland use in 1970 and projected use to the year 2020. Substantial increases are anticipated for industrial/commercial use and especially residential use. Conversely, a 400 mile decrease of shoreland is expected in the Agriculture/Forest/Undeveloped category. This category is not defined. However, it may be conceivable that "Forest" includes swamps and that "Undeveloped" includes marshes.

Figure 16 represents coastal land use changes in Lake Erie and Lake Huron. The pattern evident is a pattern similar to the remaining Great Lakes, i.e., a decrease in agricultural/forest/undeveloped use and an increase in residential uses.

A common historical pattern for wetland losses is the drainage of these habitats for agriculture followed by commercial and residential uses. In recent years, due to rapid and uncontrolled urban expansion, indiscriminate 


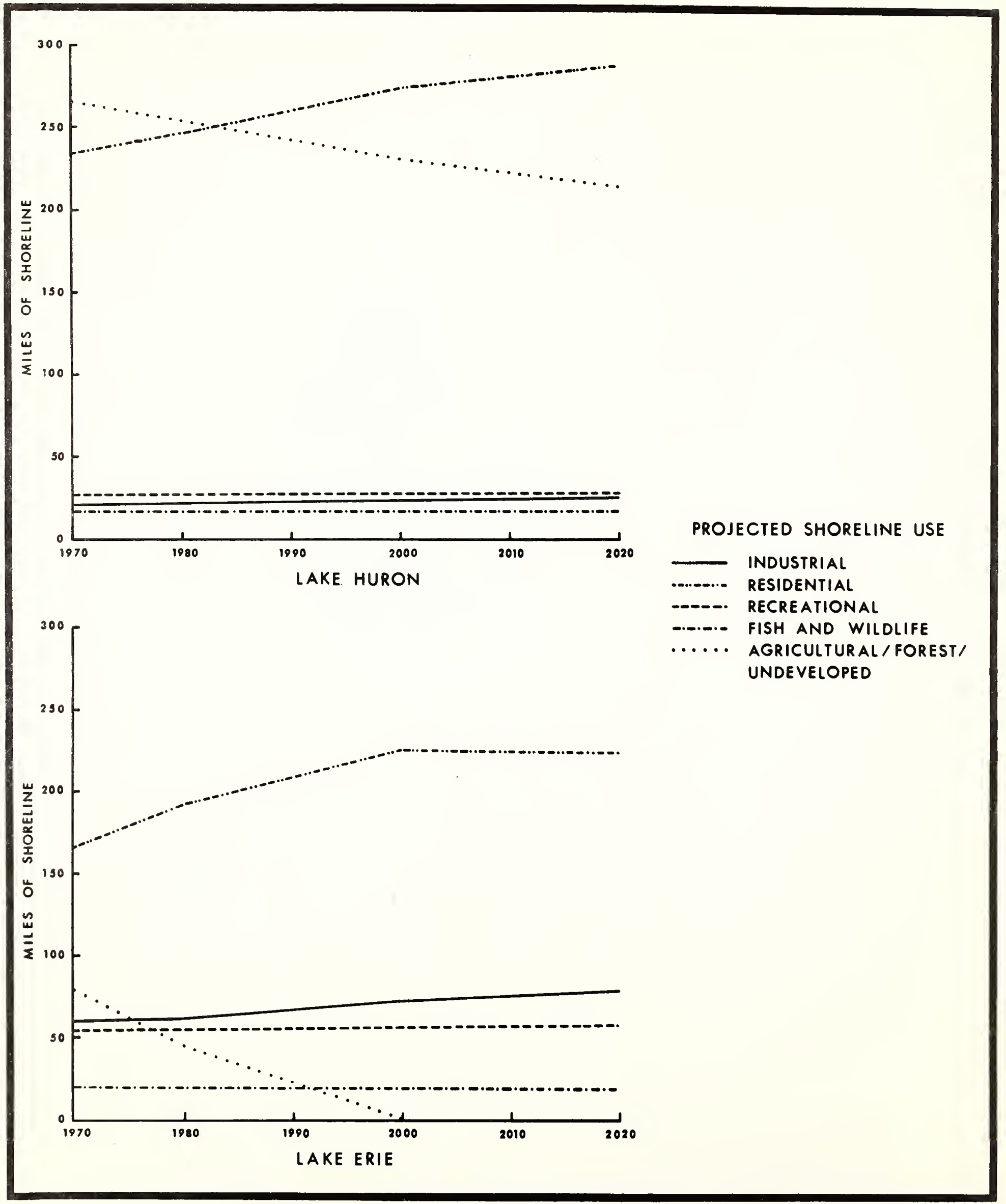

FIGURE 16--Projected Coastal Land Use for Lake Huron and Lake Erie (Great Lakes Basin Commission, Appendix 12, 1975). 
filling of wetlands has occurred (Jaworski and Raphael, 1976, p. 308-315). In addition, dredging and filling, which aid Great Lakes navigation and recreational boating, have contributed to wetland losses. Subsequently, increased soil erosion and turbidity have degraded the quality of adjacent wetlands (see Hartman, 1973; We1ls and McLain, 1973).

TABLE 11

EXISTING AND PROJECTED SHORELAND USE IN LINEAR MILES*

\begin{tabular}{lrrrr}
\hline Use & $\frac{1970}{208}$ & $\frac{1980}{234}$ & $\frac{2000}{265}$ & $\frac{2020}{293}$ \\
Industrial/Commercial & 1,119 & 1,628 & 1,246 & 1,331 \\
Residential & 321 & 328 & 352 & 365 \\
Public Park/Recreation & 57 & 55 & 55 & 55 \\
Fish and Wildlife & & & & \\
Agriculture/Forest/ & 1,691 & 1,566 & 1,393 & 1,267 \\
Undeveloped & &
\end{tabular}

Source: Modified after the Great Lakes Basin Commission, 1975, Shore Use and Erosion, Appendix 12, Great Lakes Basin Framework Study, Ann Arbor, pp. 5979 .

*Includes only U. S. shore of Lakes Superior, Michigan, Huron, and Erie. Lake St. Clair, St. Clair River and Detroit River date are included only in the 1970 column.

Based on this investigation it is clear that wetland losses are most severe near urhan areas. However, such losses are not restricted to southeastern Michigan, but are occurring throughout the Great Lakes basin. Based on the land use projections of the Great Lakes Basin Commission, shoreline urban/commercial expansion will increase in the future at the expense of agricultural, forested, and undeveloped land. Hence, additional wer-land losses and degradation may be anticipated. 
DOLLAR VALUE OF WETLAND LOSSES

As of September, 1976, the DNR held 284,235.47 acres of state game and wildlife areas at a purchase cost of 12.3 million (DNR, 1976c). The average cost per acre of this land was $\$ 43.33$. The present cost of acquisition of coastal wetlands is extremely variable (Table 12).

TABLE 12

ESTIMATED ACQUISITION COST OF SELECTED COASTAL WETLANDS IN MICHIGAN

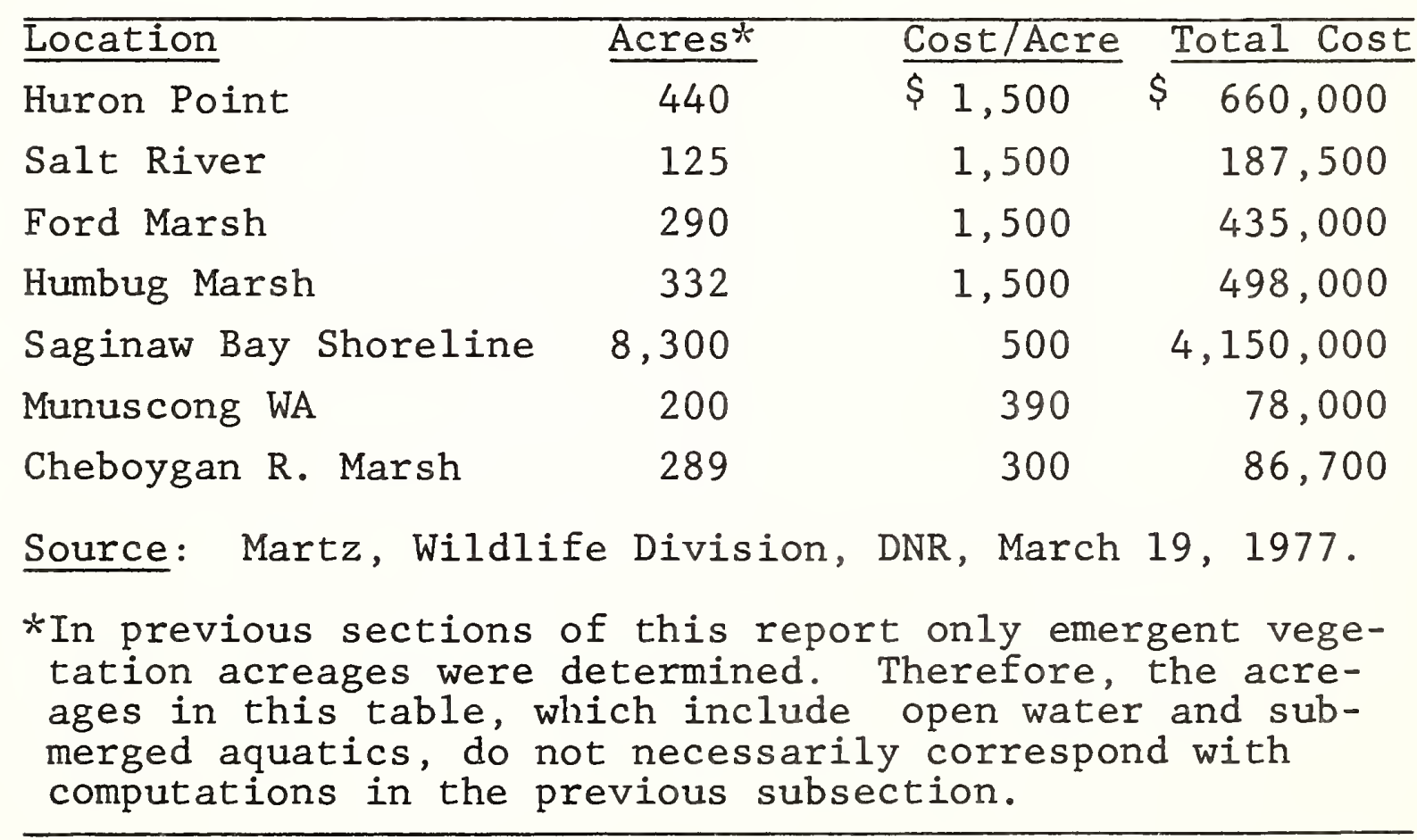

The cost to acquire additional wetland acreage at the Ford, Union Camp, and Humbug marshes for example is estimated at $\$ 1,500$ per acre. Over the years, Nayanquing Point was acquired for $\$ 161.20$ per acre, the Erie Marshes for $\$ 55.00$ per acre and the St. Clair F1ats for $\$ 22.00$ per acre (DNR, 1976c).

Generally, wetland acquisition in the past has been less expensive than suggested acquisition in the future. As noted in Table 12, to purchase a parcel of the Munuscong shoreline, it is anticipated that the DNR 
may have to pay $\$ 390.00$ per acre; the Cheboygan Marsh may cost $\$ 300.00$ per acre. It is becoming increasingly clear that the real estate value of wetlands is increasing rapidly. Furthermore, market value of coastal wetland is generally higher than inland wetlands. Coastal wetlands are valued at $\$ 1,086.25$ per acre whereas the average cost of the Muskegon River, Indian River, Sand River and Galien River floodplain areas is estimated to be $\$ 338.75$ per acre (Martz, $1977 \mathrm{a})$.

As noted in a previous subsection, the planimetered areas revealed a loss of 41,550 acres of coastal wetland. Assuming that these losses are permanent, the maximum value of wetland loss at the present market price $(\$ 1,086.25$ per acre) of just the investigated areas totals $\$ 45,133,687$. It is recognized that some wetlands were planimetered at near-record high lake levels and the marshes may regenerate as lake levels fall. However, it must also be recognized that significant permanent losses have occurred (i.e., southern Michigan), where maximum values per wetland acre are achieved (i.e., $\$ 1,500$ per acre).

A REGIONAL PERSPECTIVE OF WETLAND LOSS

On the historical topographic maps, the wetland vegetation was planimetered, and was found to total 70,130 acres. The present acreage, planimetered on recent topographical maps, totaled 28,522 acres. A comparison of the two time periods reveals a loss of some 41,000 acres, or 59 percent of the original wetlands.

Panzner (1955, p. 10) notes that by 1940,8 million acres of the state's wetlands had been drained for agriculture and for malaria control. Panzner (ibid, p. 8) also determined that the state's total wetland acreage in 1955 was 3.2 million acres. This suggests that historically Michigan had at least 11.2 million acres of wetland. An earlier estimate by Veatch (1938, p. 93) closely corresponds to Panzner's data. Veatch states, "The total area of land in Michigan which is, or was originally 
swampy, including marsh, bog and wet timbered land, may comprise more than 10 million acres of which perhaps nearly 4 million are peat and muck" (ibid, p. 93).

of the present 3.? million acres of wetlands, 105,855 acres, or 3.3 percent, occupy the coastal zone. Assuming that the coastal wetland acreage in the past existed in the same proportion to the state's total wetland area, coastal wetlands may have totalled 369,000 acres. If Michigan historically had 369,000 acres of coastal wetland and the present acreage is 105,855 it may be concluded that 263,145 acres or 71 percent has been 1ost. As noted in Table 4, historically there were 70,130 acres in the wetlands studies whereas between the 19581973 period, these same coastal wetlands totaled only 28,522 acres. In the investigated areas therefore, the coastal wetland losses totaled 41,608 acres for a loss of 59 percent of the original resource.

The 59 percent loss estimate does not consider some important variables. Panzner's objective was to determine wildlife habitat, therefore some open water and upland cover were included in his evaluation. The 1973 DNR Shoreland Inventory, taken during high-water levels of 1972, considered only emergent and submergent vegetation. Therefore, quite possibly the 3.2 million acres recorded in 1955 may actually be less in area while the 1972 inventory underestimated the wetland acreage, causing a higher estimate of the actual wetland acreage lost. 


\section{CHAPTER THREE}

\section{VALUE OF COASTAL WETLANDS TO WATERFOWL}

Important waterfowl in Michigan include ducks, geese and swans, as well as other water birds. Scientific names of waterfowl common in Michigan are listed in Appendix 1. As discussed below, waterfowl provide for both consumptive (i.e., hunting) and nonconsumptive uses with the latter increasing at a faster rate. It will be demonstrated that the coastal wetlands of Michigan provide resting and feeding habitat for migratory waterfowl as well as shooting areas on private and public lands. Because a considerable percentage of the annual harvest of waterfowl is derived from birds reared within the state, Michigan's wetlands, including the coastal wetlands, are also important as breeding areas. Finally, as nonconsumptive use of coasts near cities increases, including that of state game areas, more demand will be generated for interpretive and other types of nonconsumptive recreation in the coastal wetlands. USE OF COASTAL WETLANDS FOR MIGRATION

At least 3 million waterfow1 migrate annually through the Great Lakes region (Great Lakes Basin Comm., 1975c, p. 54). The spring and fall migrations consist of relatively large numbers of diving ducks (Figure 17), dabbling ducks (Figure 18), Canada geese (Figure 19) as well as some snow geese, blue geese, swans, and coots. As illustrated by these maps, Michigan is situated at the intersection of the Atlantic and Mississippi Flyways. Spring migration corridors are similar to fall routes except that the spring movements are more diffuse and occur along a broad front. Based on the 


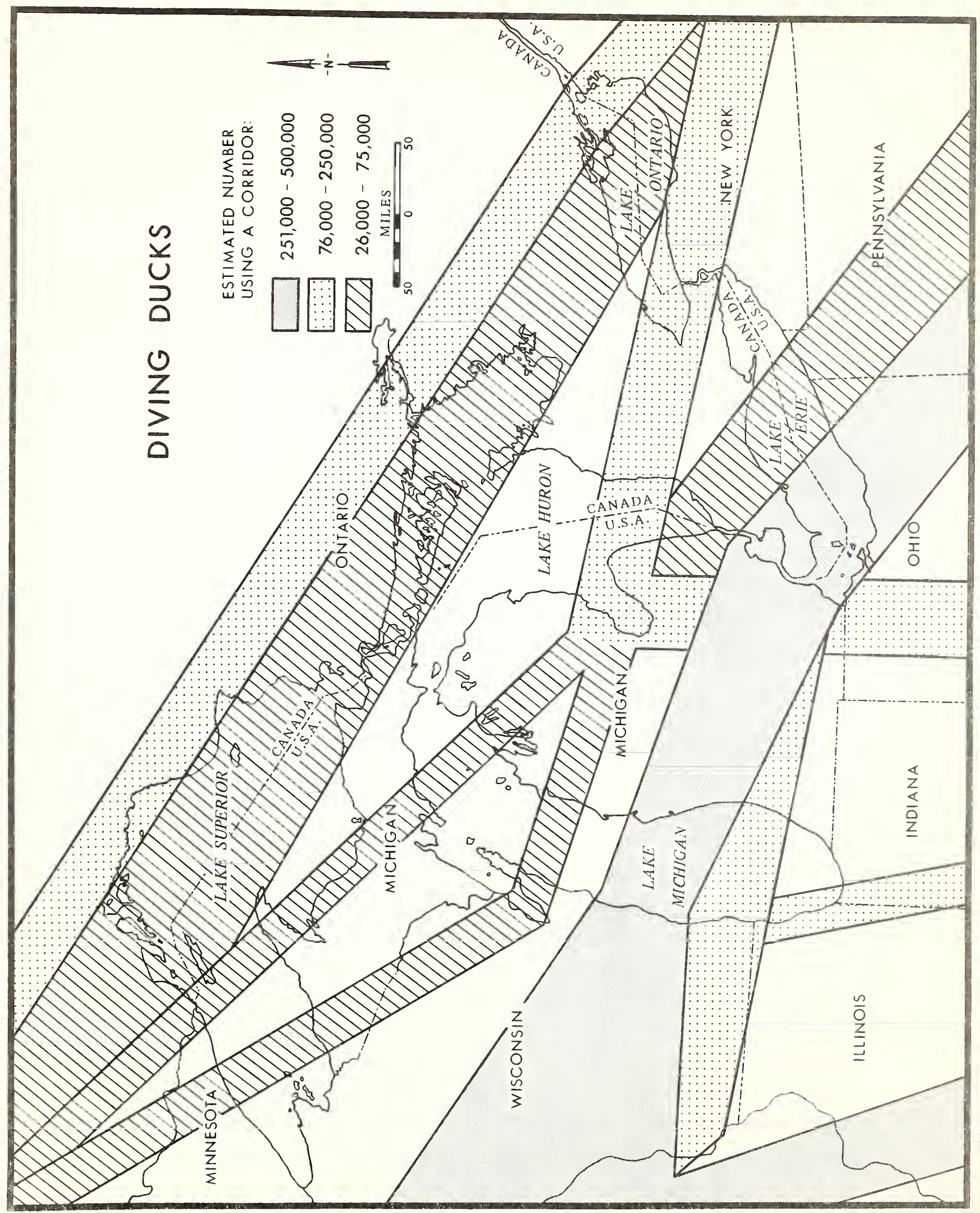




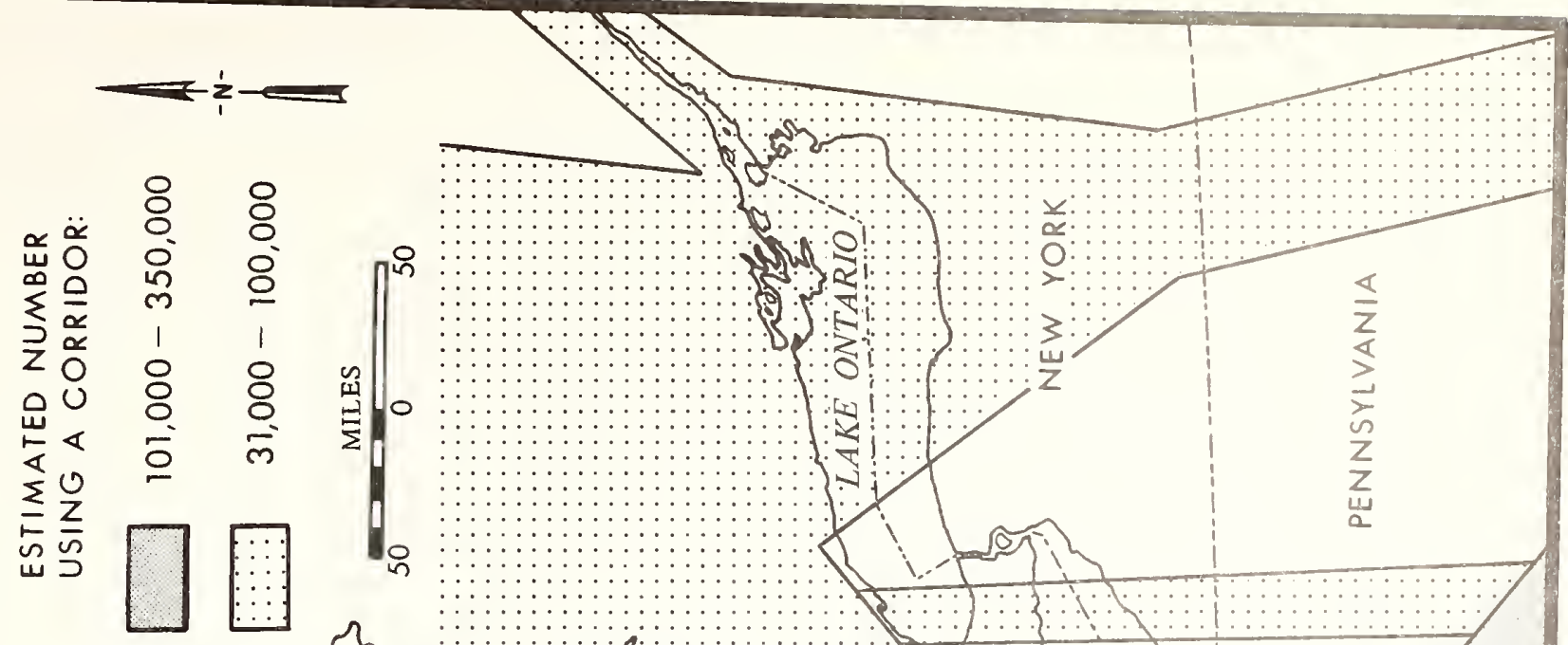

ळ

$\frac{n}{U}$

3

a

0
$z$
$\frac{1}{0}$
0
0

?
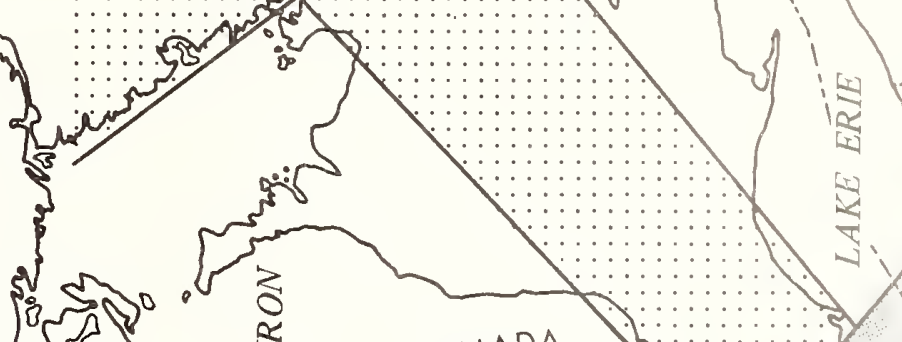


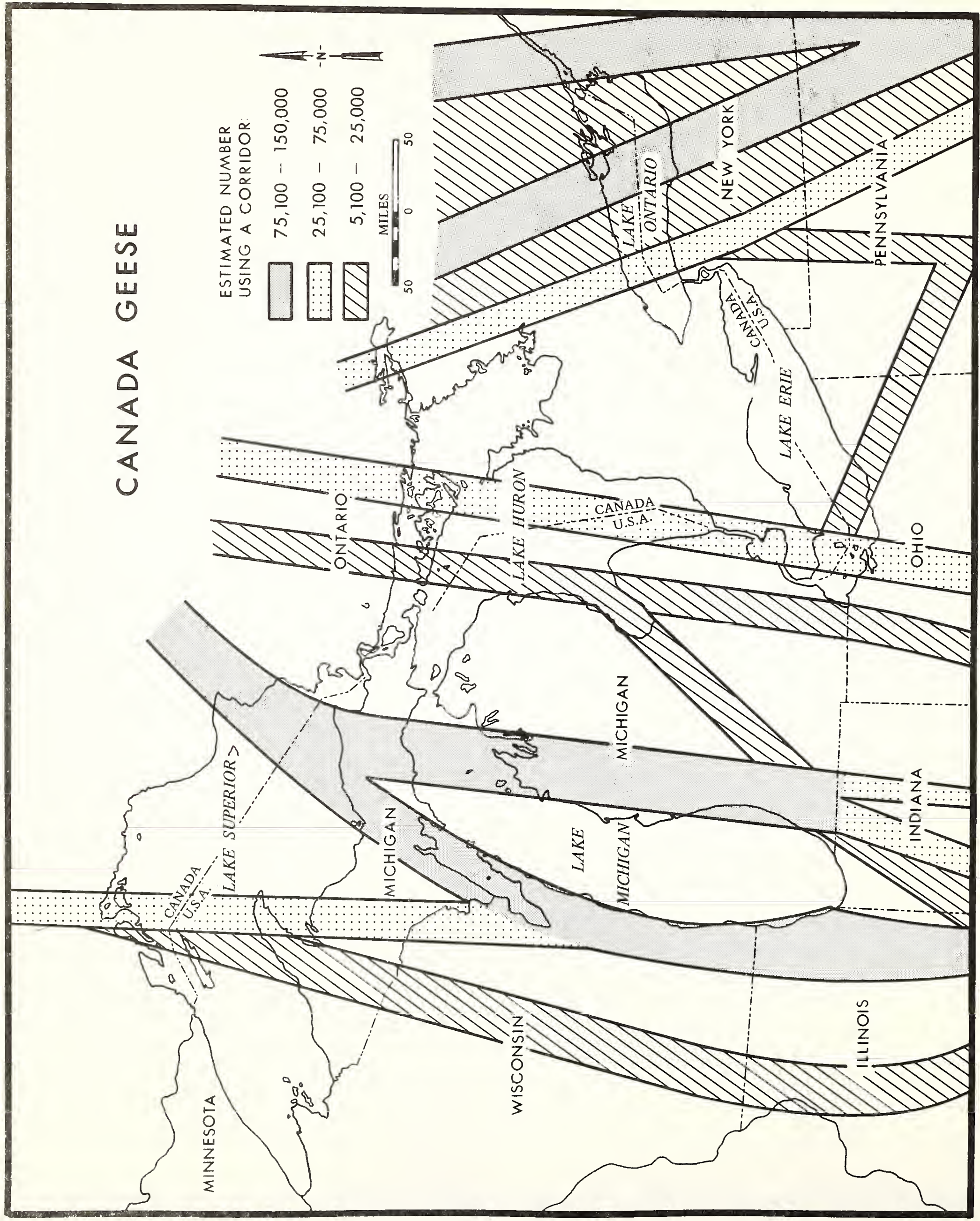


corridor data, an estimated 700,000 diving ducks, 500,000 dabbling ducks, and 250,000 Canada geese migrate each fall across some part of the State of Michigan. Because large numbers of waterfowl utilize the coastal wetlands of Michigan for resting and feeding during migration, these coastal environments have value to many states in the United States as well as to Canada.

Canada.

Fall Migration

In mid-summer, duck and coot broods being reared in Michigan wetlands begin congregating in somewhat deeper wetland environments because of the greater abundance of foods, including insects and invertebrates preferred by the young (Hunt and Mickelson, 1976, p. 51). By September, the local nesting waterfowl have gathered in large wetlands, referred to as concentration or staging areas, where plant and animal foods are plentiful. For example, a mallard brood may move from a small inland wetland in Ontario to the St. Clair flats. In September and October, severe weather in more northerly breeding grounds forces other waterfowl to funnel southward toward Michigan and into these same concentration areas.

The fall concentration areas for migratory waterfowl are illustrated in Figure 20. In general, important coastal wetland areas include coastal Monroe County, Lower Detroit River and adjacent Lake Erie, Lake St. Clair, St. Clair River, Saginaw Bay, St. Marys River, and Big and Little Bay de Noc. Diving ducks, e.g., canvasbacks, lesser scaup, and redheads tend to migrate across Lake Michigan and to stopover in the coastal wetlands and adjacent shallow waters of southeastern Michigan (Bellrose, 1968, p. 12). Lake St. Clair, with its extensive beds of submerged aquatics and relatively calm waters for resting, is nationally recognized as a concentration area for canvasbacks and redheads (Great Lakes Basin Comm., 1975c, p. 55). 


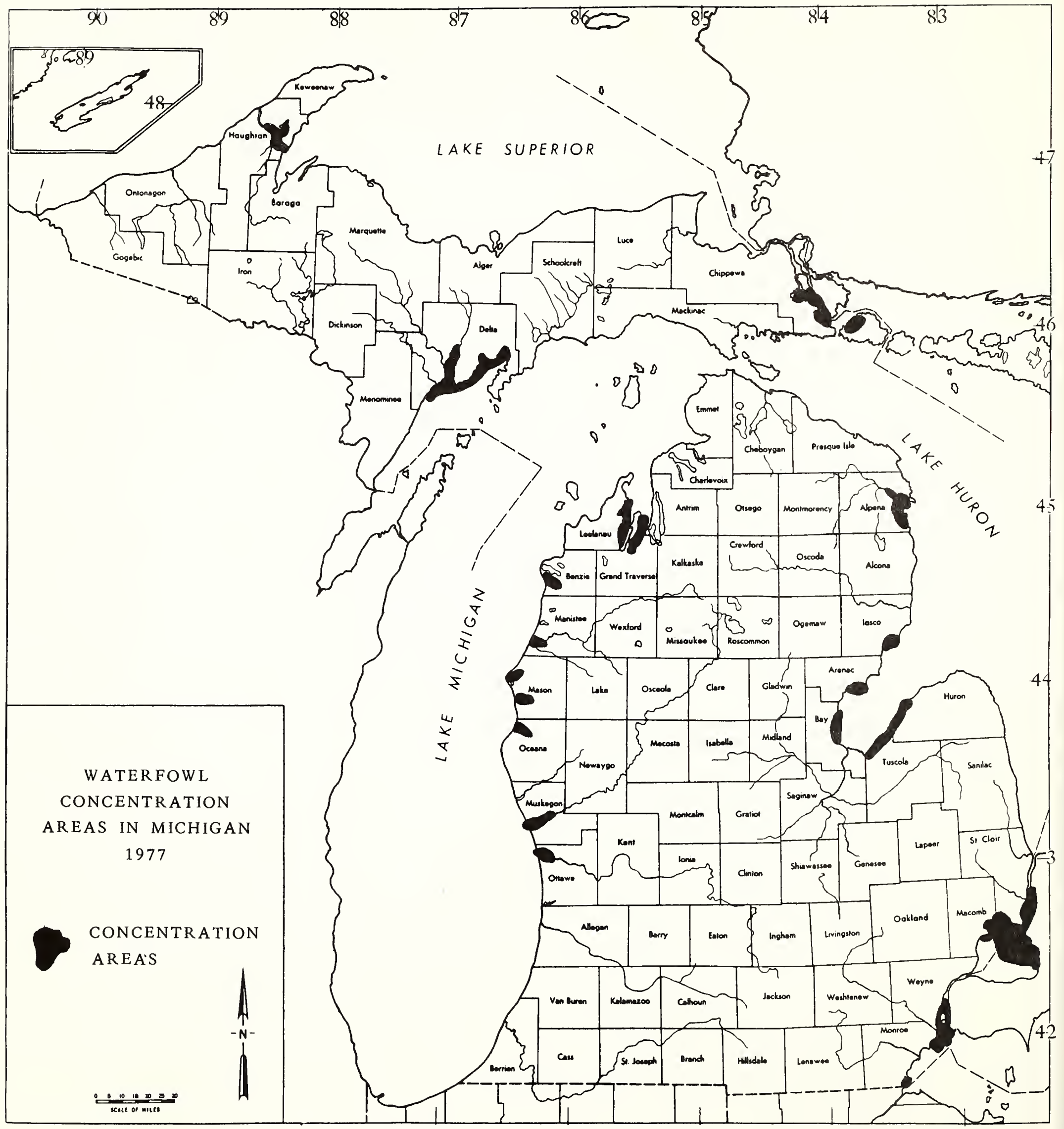

FIGURE 20--Fall concentration areas for migratory waterfowl, in Michigan, 1977, (Michigan's Coastal Wetlands), modified after Panzner, 1955. 
For several migratory waterfowl species which utilize the Great Lakes-Chesapeake Bay migration corridor, the coastal wetlands and shallow waters of Michigan constitüe critical resting and feeding habitat. As shown in Table 13, the primary and secondary migration corridors of several duck species, whistling swans, and Canada geese lie across Michigan. The principal migration corridors of whistling swans, canvasbacks, buffleheads, and ruddy ducks extend diagonally across the state, from the northwest to the southeast, with a resting stopover in the vicinity of Lake St. Clair (Be11rose, 1976, p. 96, 304, 414 and 468). Species whose secondary migration corridors traverse the state in similar fashion include redheads, greater scaup, and lesser scaup. Peak concentrations of canvasback during the 1954-1958 period, along Lake St. C1air, lower Detroit River, and adjacent Lake Erie numbered 260,000 whereas today flocks rarely exceed 50,000 birds. Because 1arger numbers of canvasbacks and other divers are being observed along the northern shores of Lake Erie in recent years, a loss and/or degradation of migration habitat in southeastern Michigan is suspected (ibid., p. 305).

TABLE 13

DUCK, GOOSE, AND SWAN SPECIES WHOSE PRIMARY AND SECONDARY MIGRATION CORRIDORS TRAVERSE THE STATE OF MICHIGAN

\begin{tabular}{ll}
\hline Primary Corridors & Secondary Corridors \\
\hline American Goldeneye & Black Ducks \\
Buffleheads & Greater Scaup \\
Canvasbacks & Lesser Scaup \\
Hooded Merganser & Redhead \\
Ruddy Duck & \\
Canada Geese & \\
Whistling Swan &
\end{tabular}

Source: Bellrose, 1976.

Coastal wetlands which currently are important concentration areas are listed individually in Table 14. 
TABLE 14

WATERFOWL CONCENTRATION AREAS IN COASTAL WETLANDS

FALL MIGRATION, IN MICHIGAN, 1976

\begin{tabular}{|c|c|}
\hline Upper Peninsula & \\
\hline Wetland Area & County (s) \\
\hline Portage Entry & Houghton \\
\hline Portage Marsh, Big \& Little Bay de Noc & Delta \\
\hline $\begin{array}{l}\text { St. Marys River, including Munuscong \& } \\
\text { Potagannissing Bays }\end{array}$ & Chippewa \\
\hline
\end{tabular}

\section{Lower Peninsula}

Wetland Area

Grand Traverse Bay

Mouth of Benzie Creek

Thunder Bay, Thunder Bay River mouth

Mouth of Manistee River, Lake Manistee

Hamlin Lake, Pere Marquette Lake

Tawas Bay, and adjacent Lake Huron

Au Gres Marsh and Wigwam Bay

Nayanquing Point, Tobico Marsh

Sebewaing and Wildfowl Bays, Fish Point, Quanicassee Marshes

Mouth of Muskegon River, Lake Muskegon, White Lake

Pentwater River mouth marshes

Lower Grand River

Lake St. Clair, Anchor Bay, marshes and embayments of Flats, including St. Johns marsh

Lower Detroit River, near Grosse Ille, Celeron Island, Horse Island, and adjacent Lake Erie

Pointe Mouillee and adjacent Lake Erie

Erie Shooting and Fishing Club, Erie State

Game Area, and waters of N. Maumee Bay
County(s)

Grand Traverse

Benzie

Alpena

Manistee

Mason

Iosco

Arenac

Bay

Huron \& Tuscola

Muskegon

Oceana

Ottawa

St. Clair \& Macomb

Wayne

Monroe

Monroe

Source: Modified after Panzner, 1955. Personal communication, Gerald Martz and Edward Mikula. 
The wetlands at the mouth of the Saginaw River, in the Lower Detroit River south of Grosse Isle, near Monroe in La Plaisance Bay, and at the mouth of the Raisin River, which were major concentration areas during the 1940's (Miller, 1943, p. 3), no longer attract large numbers of migrants due to water pollution, siltation and decrease in waterfowl foods (U. S. Dept. of Interior, 1967, p. 75 and 77 ; Bednarik et al., 1975, p. 3).

Detailed, long-term census of migratory waterfow 1 using specific wetlands are expensive to conduct, hence complete data are not available for analysis. The variability in dates of main flights due to the unpredictability of severe weather, as well as nocturnal flights and timing of surveys all affect the accuracy of census counts. To gain an impression of the relative importance of the various coastal wetlands with regard to fall migration, an examination of available waterfowl day use by wetland area is helpful (Table 15). A waterfowl day represents the use of a wetland by one bird for one day. The data in Table 15 do not suggest heavy waterfowl use of some coastal wetlands. The Ohio Department of Natural Resources considers a coastal wetland to be of high value to waterfowl if the waterfowl use exceeds 39 bird days per acre annually (Weeks, 1974, p. 6). If the Ohio standard is adopted, then the western Lake Erie shore, lower Detroit River, Lake St. Clair (U. S. side) and selected shorelands of Saginaw Bay can be regarded as high value resting sites for migratory waterfow 1 .

Documentation of the use by migratory waterfow 1 of specific coastal wetlands in Michigan is possible only for selected wetlands. Many wetlands along the western coast, such as the Hamlin Lakes areas adjacent to Lake Michigan have not been extensively inventoried by aerial surveys. Moreover, the available data contained in the Permanent 


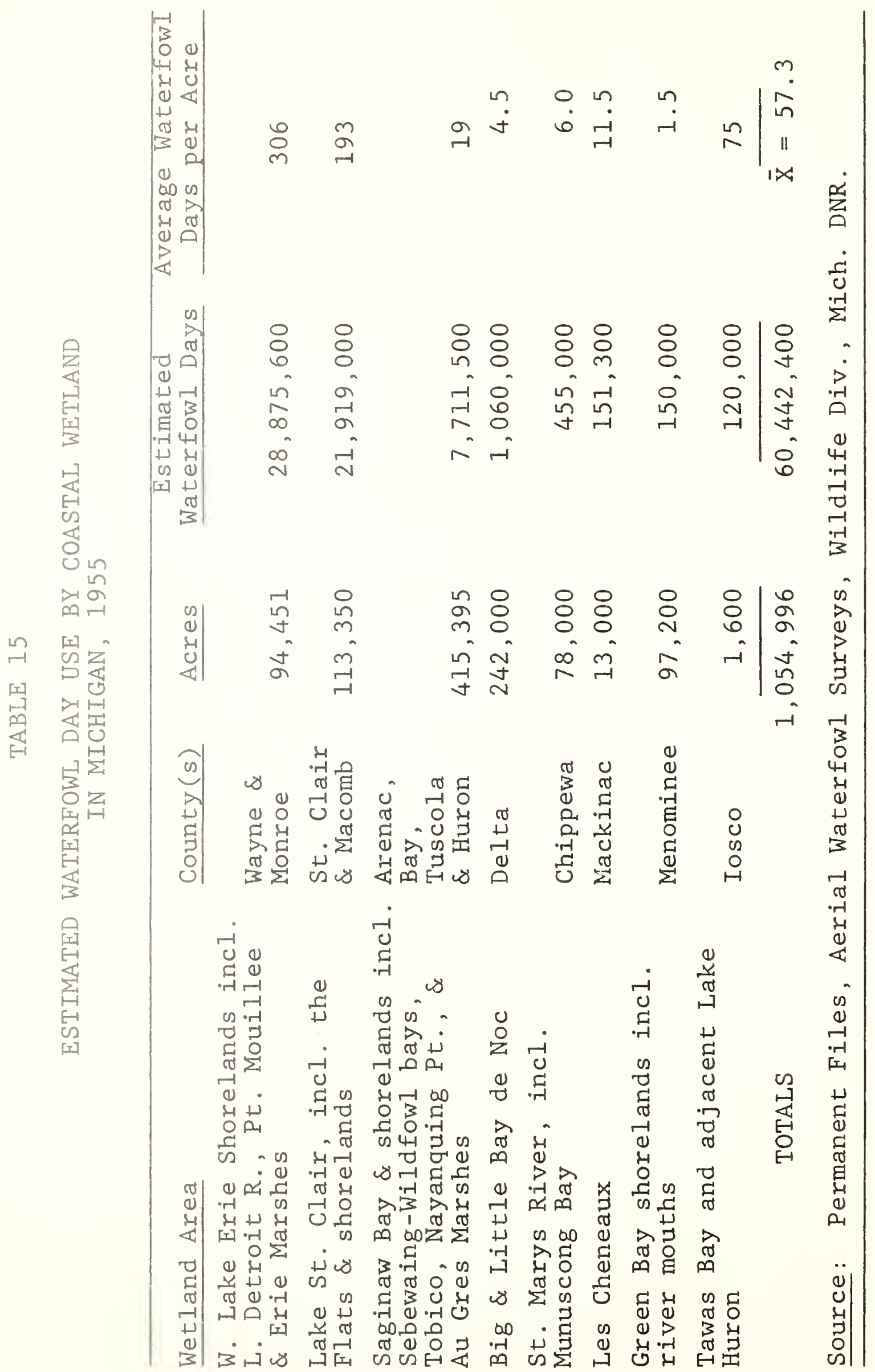


Files of the Wildlife Division, Michigan Department of Natural Resources, have yet to be reduced and summarized. With regard to specific species using the coastal wetlands for resting and feeding, the available data were scattered and incomplete. The data in Table 16 suggest that the relative numbers and species composition varies considerably from one wetland type to another. Note the concentration of mallards and other dabbling ducks on Harsen's Island where shallow marshes and grain are available, whereas diving ducks prefer the open-waters and wetlands of Anchor Bay and the Canadian side of Lake St. Clair.

The use of wetlands by migratory waterfowl appears to be a function of the species' food and resting preferences as well as the physical characteristics of the wetlands. Protection from wave action is a major factor in determining the location of waterfowl concentrations (Anonymous, 1945, p. 4). For example, the shoreline configuration, shoals, and islands collectively provide protection from waves generated in the open waters of Saginaw Bay for ducks and geese resting in Sebewaing and Wildfowl Bays (Miller, 1943, p. 71). Because the Portage Entry Marsh, Munuscong and Potagannissing Bays, Little and Big Bay de Noc, Thunder Bay, Nayanquing Point, Tobico Marsh, Lake St. Clair, lower Detroit River, and western Lake Erie marshes are protected from the prevailing westerly winds and subsequent wave action, these areas are potential waterfowl resting areas. Rafts of over 10,000 redhead ducks have been observed in St. Martin Bay, which is also protected from wave action (personal communication, Gerald Martz).

Another major factor determining the attractiveness of a fall concentration area is availability of preferred food items. Mergansers feed primarily on fish, especially forage species, and some diving ducks, e.g., American Goldeneye, prefer crayfish, clams and other 


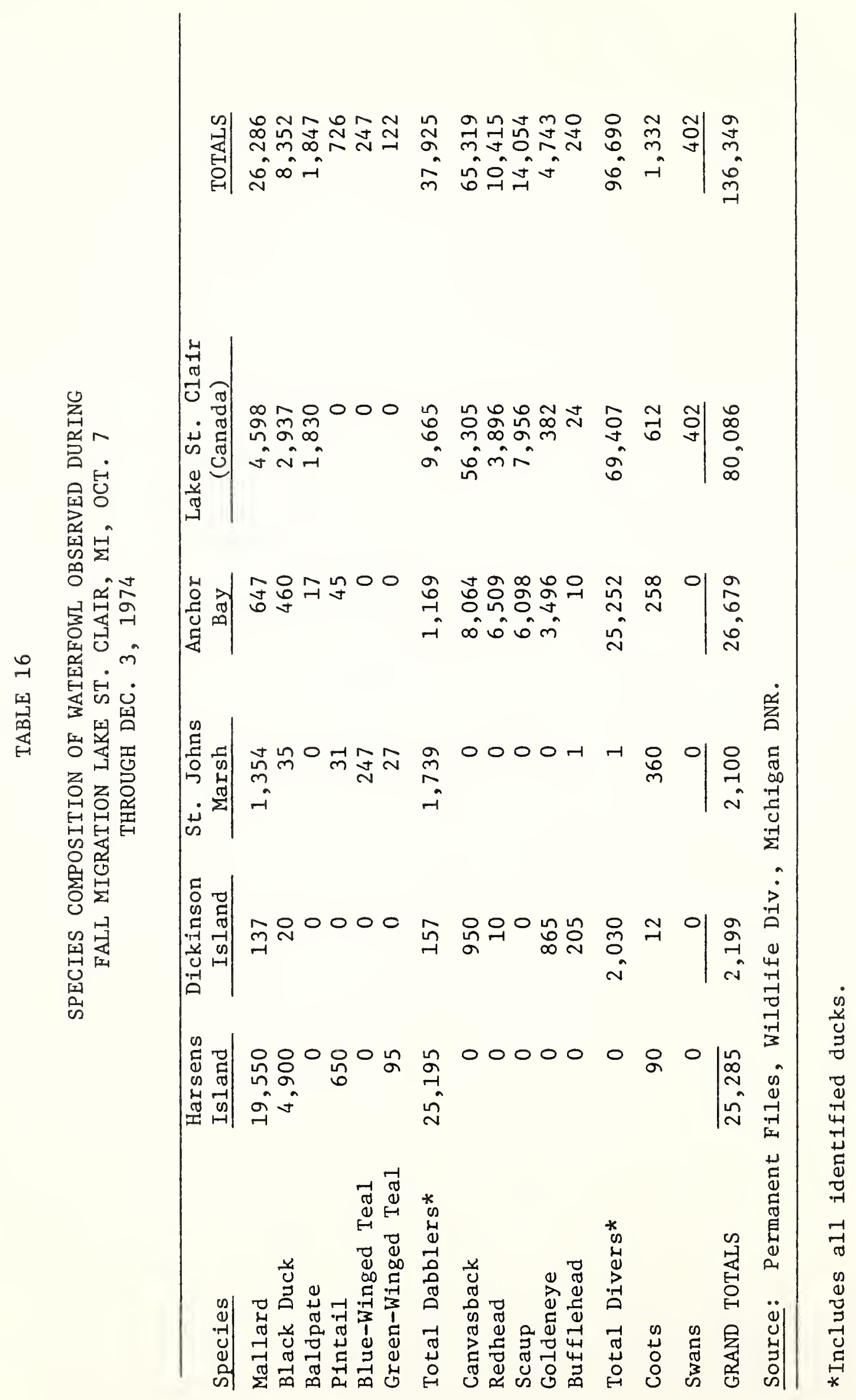


invertebrates. Other divers, particularly canvasbacks, redheads, and scaup, feed on submersed aquatics including wild celery (Vallisneria americana), pondweeds (Potamogeton spp.) and waterweed (Elodea canadensis) (Miller, 1943; Bellrose, 1976). It is generally felt that submersed plants and their associated communities provide most of the foods required by diving ducks (Anonymous, 1945, p. 2).

In contrast, dabbling ducks, including mallards and black ducks, and Canada Geese, feed on plant foods found in shallow wetlands and on waste grains in nearby agricultural fields (Miller, 1958, p. 2). A study of 126 mallard ducks shot at the Erie Shooting and Fishing Club during the 1.967 waterfowl season revealed that corn constituted 69 percent of the food volume ingested (Hunt and Mickelson, 1976, p. 53). Due to hunting pressure, mallards and Canada Geese often feed at dusk or at night in cornfields, but return after dawn to the protection of open waters. Thus, the proximity of feeding areas, i.e., in agricultural fields and in shallow marshlands, to openwater areas, as in Sebewaing-Wildfowl bays, characterize high value concentration areas for many species of dabbling ducks and Canada Geese. For that reason, many game managers, as at Fish Point, St. Clair Flats, and at Erie Shooting and Fishing Club, plant corn and other grains to attract a segment of the waterfowl population.

Few studies have been conducted on the food preference of waterfowl feeding in coastal Great Lakes wetlands. One such study (Hunt and Michelson, 1976), however, at the Erie Shooting \& Fishing Club revealed that the emergents, softstem bulrush (Scirpus validus) and nodding smartweed (Polygonum lapathifolium), and the submergents sago and curly-leaved pondweeds (Potamogeton pectinatus and $\underline{P}$. richardsonnii), are preferred food items in the diet of mallards, black duck, teal and other ducks commonly harvested in that wetland (Table 17). This study 
also demonstrated that plant foods are sufficiently abundant in the managed wetland to maintain waterfowl populations throughout the year, not just primarily during the fall and spring migrations (ibid., p. 51).

TABLE 17

UTILIZATION OF PLANT FOODS BY 150 DUCKS AND COOTS HARVESTED AT ERIE SHOOTING CLUB, 1959

\begin{tabular}{|c|c|c|}
\hline Plant Species & $\begin{array}{l}\% \text { of Waterfowl } \\
\text { Utilizing the Species }\end{array}$ & $\begin{array}{l}\text { Mean Seed Yielc } \\
\text { in } 1 \mathrm{bs} \text {. per Acre }\end{array}$ \\
\hline Softstem bulrush & 76.7 & 525.7 \\
\hline Nodding smartweed & 63.3 & 870.8 \\
\hline Sago Pondweed & 34.0 & 201.0 \\
\hline $\begin{array}{l}\text { Curly-leaved } \\
\text { pondweed }\end{array}$ & 32.7 & 319.9 \\
\hline Hunt and & Mickelson, 1976, p. 48. & \\
\hline
\end{tabular}

Other investigations of available waterfowl foods in coastal wetlands include Miller's 1943 study of Sebe-waing-Wildfowl Bays, Hunt's 1952 and 1963 surveys of submergent vegetation in the lower Detroit River, and some quantitative estimates of plant foods present along the St. Marys River contained in International Lake Superior Board of Control, 1974. These three areas are important concentration areas.

A recent decline in scaup harvests along Saginaw Bay may be related to a decrease in the extent of submersed aquatics as a result of siltation and increased turbidity (Martz and Ostyn, 1977, p. 15). Water pollution is also associated with a decline in the abundance of wild celery in the Detroit River (U. S. Dept. of Int., 1967, p. 90). In addition, siltation, turbidity and other forms of water pollution have drastically reduced the once abundant wild celery and other submersed aquatics within the western Lake Erie wetlands. This vegetation 
change has been associated with the decrease in the harvest of divers, including canvasback, redhead, and scaup, which until recently constituted the basis of duck hunting in the area (ibid., p. 88-89). Because of differences in food preferences, dabbling ducks and Canada Geese appear to have been less impacted by this environmental degradation (Bednarik et al., 1975, p. 3).

In contrast, a recent study of Anchor Bay, located in northern Lake St. Clair, suggests that only a small percentage of the desirable aquatic plants and invertebrates available to migrant diving ducks is currently being utilized (Dawson, 1975, p. 69). Hunting pressure and disturbance by boaters and fishermen, even in the refuge area, forces the main flocks to leave the U.S. waters of Lake St. Clair before the food supplies are consumed (personal communication, Leo Pospichal). In the $1930^{\prime} \mathrm{s}$ and $1940^{\prime} \mathrm{s}$, as many as 750,000 ducks congregaged on Lake St. Clair during the fall migration (Miller, 1943), p. 9). This availability of waterfowl foods is significant because Lake St. Clair is nationally renowned as a fall concentration area for migrating canvasbacks, redheads, scaup, and buffleheads (ibid, p. 5).

Based on data collected in the fall of 1941 and 1942, the average length of stay by migratory waterfow 1 in a given wetland in Michigan was 33 and 35 days, respectively (Miller, 1943, p. 9 and 35). Unless forced to move on by severe weather or hunting pressure, ducks tend to linger in the concentration areas. The main flights of dabbling ducks occur in late September or October, whereas divers appear somewhat later in October and November. Fall flights of canvasbacks, redheads and scaup generally appear first at the western Lake Erie-Lower Detroit River concentration area, then within a few days thereafter in Lake St. Clair and along Saginaw Bay. Compared to some other ducks, canvasbacks are prone to utilize specific 
geographic concentration sites such as Lake St. Clair (Martz et a1., 1972, p. 9). In contrast, redheads tend to be more widely scattered along the flyway corridors. Scaup tend to arrive at western Lake Erie-Lower Detroit River sites in November where they are harvested by hunters in relatively large numbers (Martz and Ostyn, 1977).

As illustrated in $r \perp$ gure 19, Canada Geese tend to migrate along the coasts of Michigan. At present, the major fall concentration areas include the Fish Point State Game Area, Seney National Wildlife Refuge, Baraga Plains Wildlife Area, Shiawassee River National Wildlife Refuge and State Game Area, Fenville Farm area, Kellogg Bird Sanctuary, Leidy Lake State Game Area, and other small sites (personal communication, Gerald Martz). Miller (1943, p. 123) listed the coastal concentration areas important during the 1940's, and emphasized the islands and marshes of Saginaw Bay. In 1975 Canada Geese began arriving at the Fish Point area of Saginaw Bay in mid-September and peaked at about 4,000 in number in early October (Jarvis, 1975a). Though many geese from the Saginaw Bay area migrate south toward Ohio, a significant number also move diagonally across the state toward the southwest

Spring Migration

In general, the spring migration of waterfow1

follows the same corridors as during the fall migration. However, the movement is less restricted to specific wetlands as waterfowl are often observed on lakes and in wetlands which they did not frequent in the fall. Hence, the waterfowl tend to be somewhat more scattered, and therefore draw on aquatic foods over a larger area than in the fall. Submersed aquatic plants such as wild celery, are particularly important to waterfowl during spring migration. With regard to dabbling ducks and Canada Geese, waste grain in agricultural fields is most important. If the food supplies are inadequate, waterfowl may arrive at breeding areas in poor condition, which, in turn, can 
reduce nesting success (personal communication, Leo Pospicha1). In Michigan's breeding grounds, the establishment of territories and nesting may be initiated in late March (Hunt and Mickelson, 1976, p. 34).

The northward advance of waterfowl in spring is governed by the ice breakup (Miller, 1943, p. 13). As snowmelt occurs and ice-free areas appear in the water bodies, a wave of northward migration follows. Main spring flights begin in mid-March in the southeast corner of Michigan (Table 18). Ducks usually congregate along western Lake Erie, in Lake St. Clair, and along the shorelands of Saginaw Bay. If the weather is mild, flights appear by March 10, and most flocks have departed by April 1st. The main flights require only approximately 45 days to pass through the state (ibid., p. 11). By May 1st, most flocks of ducks and geese have passed through the northern part of the state.

In contrast to the fall migration, the spring migrants appear restless and hurried, even though there is no hunting pressure and less disturbance by boaters. Many ducks arrive in concentration areas already paired. The average time spent by waterfowl at a concentration site is 11 days (ibid., p. 11). On March 27, 1941, an estimated 400,000 ducks congregated on the east side of Grosse Ile on the Detroit River. Ninety percent of these ducks were divers, the most numerous of which, in order, were: canvasbacks, scaup, redheads, buffleheads, and goldeneyes (ibid., p. 7). Lake St. Clair is a usual resting and feeding stop for these spring migrants.

Census of spring waterfowl migrations are incomplete in Michigan. However, to provide a perspective of the species composition and relative numbers of migrants, some census data pertaining to southeast Saginaw Bay is presented in Table 19. Note that the aerial survey revealed a large variation in the species present as well as in 
TABLE 18

\section{SPRING MIGRATION CALENDAR BY WATERFOWL SPECIES IN MICHIGAN'S COASTAL WETLANDS}

\begin{tabular}{|c|c|c|c|c|}
\hline Wetland Area & $\begin{array}{l}\text { Arrival } \\
\text { of lst } \\
\text { Migrants } \\
\end{array}$ & $\begin{array}{l}\text { Arrival } \\
\text { of Main } \\
\text { Flights } \\
\end{array}$ & $\begin{array}{l}\text { Departure } \\
\text { Date } \\
\end{array}$ & $\begin{array}{l}\text { Principal } \\
\text { Species } \\
\end{array}$ \\
\hline Monroe Marshes & Mar. 10 & Mar. 15 & Mar. 20 & $\begin{array}{l}\text { Widgeon, pintail } \\
\text { Mallards, B. duck }\end{array}$ \\
\hline L. Detroit River & Mar. 10 & Mar. 20-25 & Mar. 30 & Scaup, canvasback \\
\hline Lake St. Clair & -- & Mar. 20-30 & Mar. 30 & $\begin{array}{l}50-50 \text { Divers and } \\
\text { Dabblers }\end{array}$ \\
\hline Sebewaing Bay & Mar. 28 & Apr. 1 & $\begin{array}{ll}\text { Apr. } & 4 \\
\text { Apr. } & 20\end{array}$ & $\begin{array}{l}70 \% \text { divers } \\
\text { Canada Geese }\end{array}$ \\
\hline $\begin{array}{c}\text { Squaw Bay and } \\
\text { Thunder } R \text {. }\end{array}$ & Apr. 10 & Apr. 16 & Apr. 20 & $\begin{array}{l}\text { Both divers and } \\
\text { dabblers }\end{array}$ \\
\hline $\begin{array}{c}\text { Hayward Lake } \\
\text { Green Bay }\end{array}$ & Apr. 10 & Apr. 15 & $\begin{array}{l}\text { Apr. } 15 \\
\text { (ducks) } \\
\text { Apr. } 30 \\
\text { (geese) }\end{array}$ & $\begin{array}{l}\text { Both divers and } \\
\text { dabblers } \\
\text { Canada Geese } \\
\text { Black ducks }\end{array}$ \\
\hline Munuscong Bay & Apr. 4 & Apr. 10-18 & -- & $\begin{array}{l}\text { Mallards, BW } \\
\text { teal, scaup, } \\
\text { goldeneye. } \\
\text { Many geese. }\end{array}$ \\
\hline Source: Miller, & 1943, p. 14. & & & \\
\hline
\end{tabular}

the total numbers of waterfowl. Timing of aerial census flights, as well as nocturnal flights and leapfrogging of concentration areas cause variations in the data which must receive careful interpretation.

Canada Geese, in spring, utilize the Kalamazoo River and the eastern side of Saginaw Bay as concentration areas. A main flight of Canada Geese in spring occurs diagonally across the state from the southwest corner to the Saginaw River valley and Saginaw Bay, then north along the eastern side of the state (Miller, 1943 , p. 11). As many as 30,500 Canada Geese congregate at a time in the Sebewaing-Wildfowl Bay area of Saginaw Bay (1'able 19). Resting and feeding also takes 


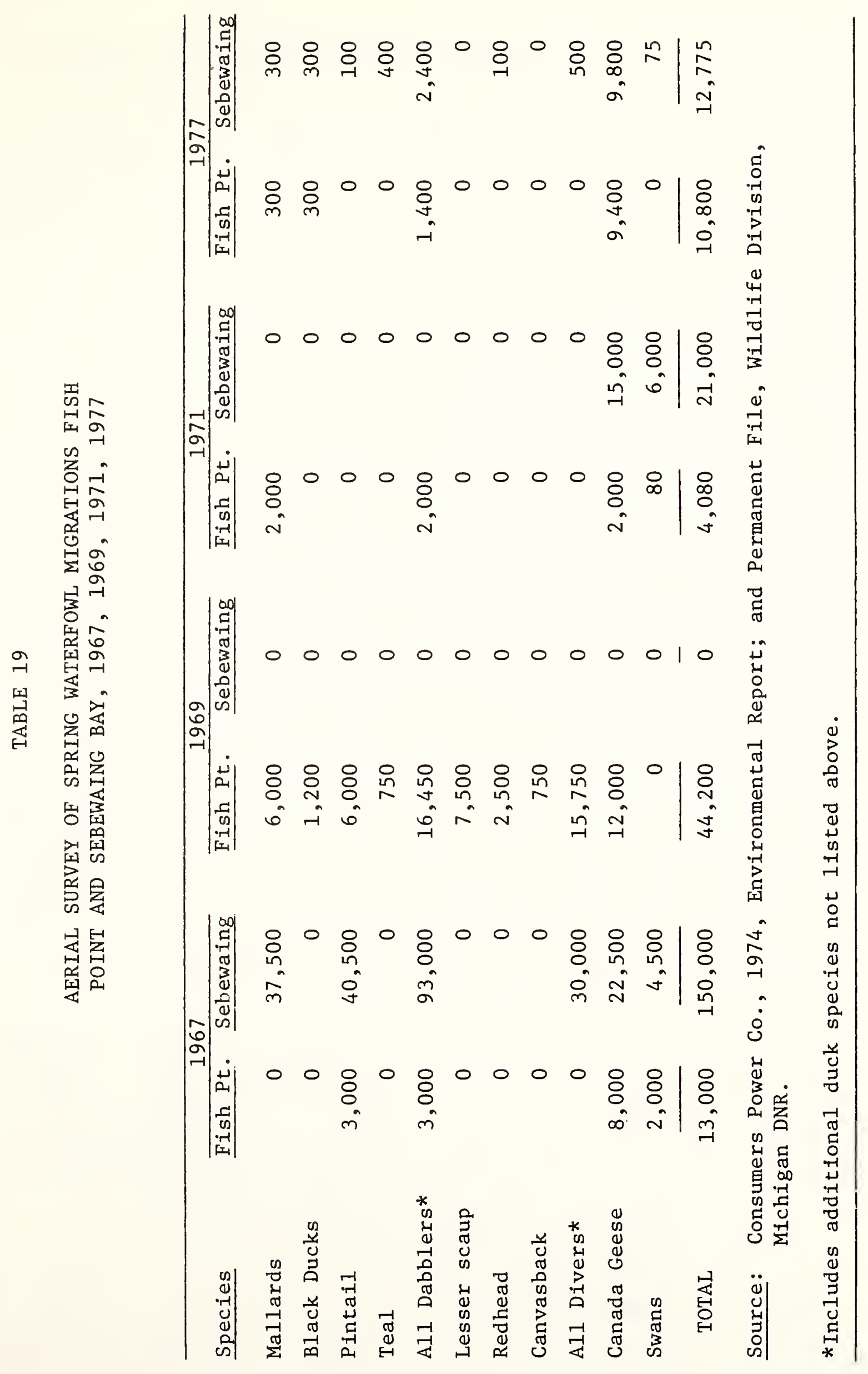


place in Squaw and Misery Bays of the Thunder Bay area (Miller, 1943, p. 125).

Economic Value of Waterfowl Migration

An economic value for Michigan's coastal wetlands with regard to waterfowl migration cannot be established at this time. First, data regarding the average waterfowl day use of each wetland area by species are not available except for selected areas, particularly in southeastern Michigan. Secondly, because the migratory waterfowl provide both consumptive and nonconsumptive uses in Michigan and in other states, as well as in Canada, a dollar value based on Michigan's utility greatly underestimates the actual total value. Migrants, sucn as whistling swans, canvasbacks, buffleheads, ruddy ducks, and coots, are dependent upon Michigan's coastal wetlands and shallow waters for resting and feeding during migration, and in general travel from the Canadian prairie provinces to and from the Atlantic coast.

The value of wetlands.recently purchased by the state of Michigan for wildlife purposes ranged from $\$ 300$ to $\$ 1,500$ per acre (see Table 12). Wetlands and associated uplands of Pointe Mouillee, which were purchased during the past few years, cost the state approximately $\$ 1,500$ per acre. Many of the coastal wetlands purchased by the state are considered to be of high value to waterfowl as indicated elsewhere in this chapter.

Loss of Migration Habitat

In 1952-1955, a survey revealed that there were 310,500 acres of high-value waterfowl habitat in the state of Michigan (Miller, 1958, p. 1). A survey in March, 1976 indicated that 259,443 acres of high-quality waterfowl habitat were inadequately protected from private development (Martz, 1976, Table 1). Of the 259,443 existing acres, 219,000 acres serve as highquality migration habitat. An analysis reveals that nearly 24 percent, or 53,286 acres, of quality migration 
habitat is contained within or immediately adjacent to the coastal wetlands. Jurrent projections indicate that 32,645 acres of high-quality coastal migration habitat may be impacted by development, at least in part, within five years (Table 20). Only the tracts of publicly-owned land, or that contained within the Erie Shooting and Fishing Club, appear reasonably safe from foreseeable development by the private sector. Moreover, record high-water levels in the Great Lakes during the 1972-75 period aggravated this migration habitat loss by temporarily drowning deepwater marshes and rupturing diked marsh enclosures.

The threatened migration habitats which are located within coastal wetlands are mapped in Figure 21. A comparison of these threatened areas with the fall migration concentration areas in Figure 20 reveals considerable overlap. Wetlands which are threatened or have already been developed include: Raisin River mouth, lower Detroit River, Saginaw Bay shoreline near Bay City, St. Marys River, Nuns-Prentiss Bays and vicinity, Houghton Entry Marsh, Grand Haven Marsh, Muskegon Lake and marsh, and Lake Macatawa Marsh (Table 20).

A preliminary survey by the U.S. Bureau of Sport Fisheries and Wildlife revealed serious future migration habitat deficiencies in Michigan. The potential for waterfowl use of migration and wintering habitat was studied for six regions of Michigan as shown in Table 21. In all three habitat projections--fall migration, spring migration and wintering, southeastern Michigan exhibits 
TABLE 20

LIST OF THREATENED COASTAL WETLANDS WHICH FUNCTION FOR WATERFOWL MIGRATION, IN MICHIGAN, 1976

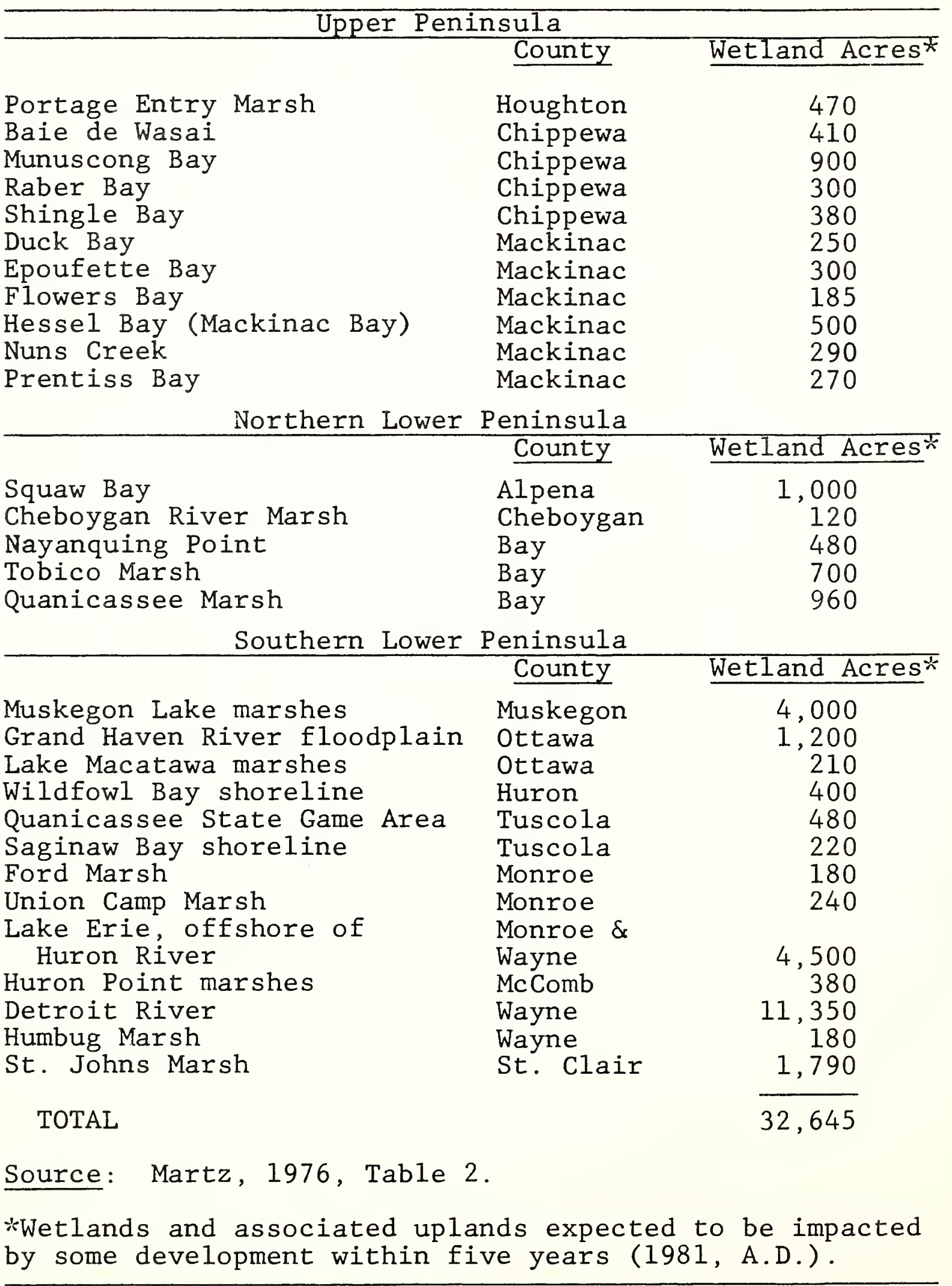




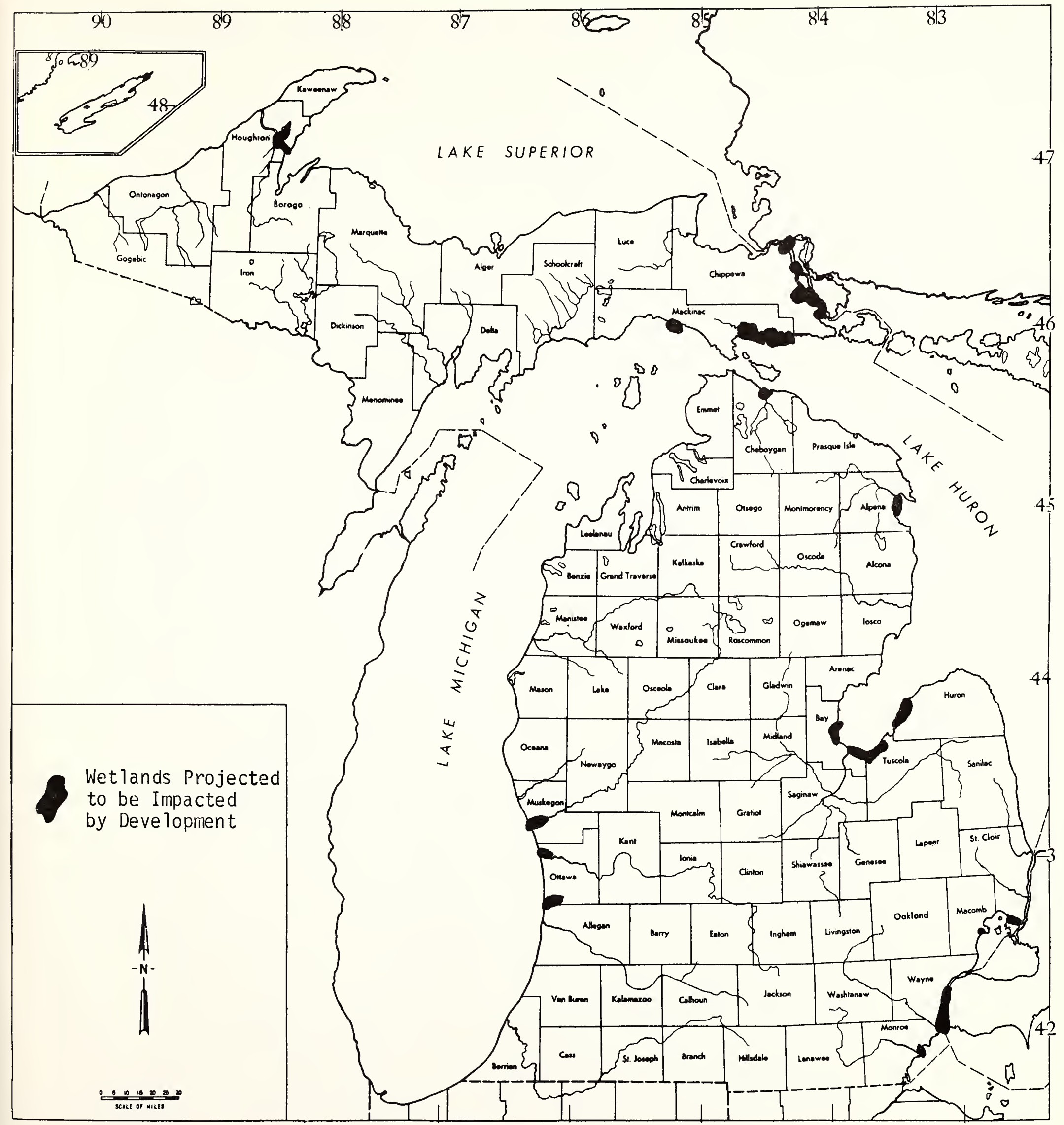

Figure 21. Threatened migration habitats in the coastal wetlands of Michigan. Data from Martz, 1976, Table 2. 
habitat deficiencies for the year $2000 \mathrm{~A}$. D. The Saginaw Bay-Thumb area likewise shows a large fall migration habitat deficiency and has little surplus in the other seasons. Since it is state policy not to encourage wintering of waterfowl in Michigan, the lack of adequate wintering habitat, except for selected localities, is not significant.

TABLE 21

DEFICIENCIES IN FUTURE MIGRATION AND WINTERING HABITAT IN MICHIGAN BY FLYWAY HABITAT REGION, YEAR 2000 A. D., IN $1000^{\prime} \mathrm{S}$ OF WATERFOWL

Flyway Habitat

Region

W. Upper Peninsula

E. Upper Peninsula

N. Lower Peninsula

Saginaw Bay-Thumb Area

SW Lower Peninsula

SE Lower Peninsula

Habitat Deficiency or Surplus*

Fall

Migration

$+397$

$+208$

$+155$

$-262$

$+276$

$-295$

$$
\text { Spring }
$$

Migration

$+848$

$+604$

$+578$

$+4$

$+622$

$-273$
Wintering

$+341$

$+248$

$+248$

$+41$

$+250$

$-76$

Source: U. S. Dept. of Interior, 1971, FHUMP Report No. 8.

*Includes wetland types 3 and 4 (shallow and deep fresh marsh), Circular 39, (see Table 3 of this report).

Usually the elimination or degradation of migration habitat causes shifts in the migration patterns of waterfowl as opposed to creating absolute habitat deficiencies which might reduce the waterfowl population (personal communication, Harold Prince). Thus the habitat projection data suggest reduced use by migratory waterfowl of the Saginaw Bay and southeastern Michigan regions, including the coastal wetlands therein. Changes in the migration patterns, in turn, affect the economy of the regions involved because of reduced participation rates in waterfowl hunting and birdwatching. 
USE OF COASTAL WETLANDS AS BREEDING HABITAT

Michigan's kettle lakes, river-bottom wetlands, and coastal marshlands are important breeding areas for waterbirds, including ducks, geese, coots, grebes, loons, gallinules and rails. With regard to nesting of puddle (or dabbling) ducks e.g., mallards, blue-winged teal, wood ducks and black ducks, Michigan is part of a large breeding area which includes the Great Lakes region (Johnsgaard, 1975, pp. 224, 246 and 275). A1though some diving ducks do breed in the northern Great Lakes states, e.g., the ring-necked duck and the red-head, the prairie provinces pothole region of the Dakotas and adjacent Canada as well as the northwest territories and Alaska comprise the principal nesting grounds. In comparison to ducks, Canada Geese do not nest in Michigan in large numbers except in sizeable wetlands especially where aided by muskrat houses and natural or artificial islands and nesting structures. Pairs of breeding coots and gallinules are frequently even more numerous in Michigan's wetlands than nesting ducks.

Important species of nesting ducks in Michigan are indicated in Table 22. At present, breeding ducks in the coastal wetlands are dominated by dabbling ducks including mallards, blue-winged teal, and black ducks. If nesting boxes are available, as in the Erie Shooting and Fishing Club Marsh, then wood ducks may also be quite numerous. Diving ducks, e.g., redheads, though never very abundant, were more common in the past. Currently, small numbers of redheads nest in St. Johns Marsh along Lake St. Clair (Dept. of Natural Resources, 1976b), but a significant population breeds on Harsens Island and along lower Walpole Island (personal communication, Leo Pospichal).

Duck species nesting in the coastal wetlands, i.e., the common mallard and the blue-winged teal, are classified as meadow nesters. Preferred nesting habitat includes grassy meadows, adjacent hayfields, and shallow marsh 
TABLE 22

SPECIES OF DUCKS NESTING IN THE COASTAL WETLANDS

AND IN FORESTED INTERIOR OF MICHIGAN, AND MAGEE MARSH, N. OHIO

\begin{tabular}{|c|c|c|c|c|}
\hline Species & $\begin{array}{l}\text { Erie Shoot- } \\
\text { ing Club } \\
\text { 1957-1968 } \\
\end{array}$ & $\begin{array}{l}\text { Nayanquing } \\
\text { Point } \\
1969 \& 1973 \\
\end{array}$ & $\begin{array}{c}\text { Forested } \\
\text { Interior } \\
1968-69,73 \\
\end{array}$ & $\begin{array}{c}\text { Magee Marsh } \\
\text { N. Ohio } \\
1953-1969 \\
\end{array}$ \\
\hline Mallard & $39.0 \%$ & $48.5 \%$ & $40 \%$ & $30.7 \%$ \\
\hline Blue winged teal & 13.0 & 35.5 & 48 & 41.5 \\
\hline Wood duck & 12.0 & 0.0 & 1 & 16.7 \\
\hline Black duck & 18.5 & 4.0 & 6 & 7.4 \\
\hline Pintail & 3.5 & 4.0 & 0 & 0.7 \\
\hline Shoveler & 0.0 & 7.0 & 3 & 0.9 \\
\hline Redhead & 2.0 & 0.0 & 0 & 1.2 \\
\hline Green Winged & & & & \\
\hline teal & 0.0 & 1.0 & 2 & 0.9 \\
\hline Unknown ducks & 12.0 & 0.0 & 0 & 0.0 \\
\hline TOTAL & $100.0 \%$ & $100.0 \%$ & $100 \%$ & $100.0 \%$ \\
\hline \multicolumn{5}{|c|}{$\begin{array}{l}\text { Hunt and Mickelson (1976), Martz (1977) and Bednarik and } \\
\text { Weeks, (1971). }\end{array}$} \\
\hline
\end{tabular}

environments. As agricultural and other development occurred along the landward margin of the coastal wetlands, particularly within the dogwood meadows and sedge marshes along Saginaw Bay, lower Detroit River and coastal Monroe County, a loss of habitat for meadow nesters resulted. The continued abundance of mallards may be partially due to this species' remarkable versatility with regard to nesting sites. Mallards generally prefer blue-joint grass meadows (Andrews, 1952, p. 137), but will nest in hayfields, sedge meadows, along artificial dikes, and atop abandoned muskrat houses. Mallards will also use artificial nesting structures of various design (Jarvis, 1975b, p. 2).

Coots and gallinules have nesting habitat preferences similar to diving ducks in that floating nests are commonly constructed on rafted debris within deep-water cattail or bulrush marshes. Redheads nest atop muskrat 
houses and rafted debris or construct nests in vegetation along the shoreline (Miller, 1943, p. 78). A loss of deepwater marsh habitat to nest in, and a decline of submersed aquatic foods, perhaps due to increased turbidity, are suggested as causes for the general decrease in nesting divers (Bednarik et al., 1975, p. 3). The building of summer camps, dredging of boat slips, and other disturbance factors, including filling, boating and fishing, are associated with the decline of the redhead and other diving ducks nesting along the main channels of the St. Clair delta (personal communication, Leo Pospichal). In Michigan, Canada Geese commonly nest on muskrat nouses within large cattail marshes (Mich. DNR, 1975b, p. 315).

Several species of ducks, i.e., ringnecks, wood ducks, and hooded and common mergansers, have primary breeding ranges which include portions of Michigan (Be11rose, 1976, p. 180, 327, 441 and 457). However, with the exception of wood ducks, these species do not commoniy nest in the coastal wetlands (see Table 22). The wooded floodplain of the Kalamazoo River and other rivers constitutes a prime breeding area for wood ducks in Michigan. Although whistling swans once nested in Michigan, at present the only swan commonly nesting in the coastal wetlands is the mute swan which breeds in the Grand Traverse Bay Region (Koechlein, 1971, p. 2) .

For the purpose of this report, it will be assumed that the duck species nesting in the coastal environments consist of 40 percent mallards, 30 percent blue-winged teal, 10 percent black ducks and 21 percent all other species. Current estimates of the number of breeding pairs of ducks in Michigan are indicated in Table 23. The number of breeding pairs of mallards may actually be as high as 40,000 (personal communication, Gerald Martz). If one accepts that there are 40,000 pairs of breeding mallards 
then Michigan may have approximately 100,000 pairs of breeding ducks each year. The remaining 60,000 breeding pairs are primarily blue-winged teal, wood ducks and black ducks. Some incidental species may also nest in Michigan in small numbers, e.g., ringnecks, redheads, mergansers, etc. The data concerning breeding pairs will be utilized to estimate the number of ducks produced in Michigan's coastal wetlands.

TABLE 23

NUMBER OF BREEDING PAIRS OF DUCKS IN MICHIGAN, 1976

Species

Mallards

Wood duck

Blue-winged teal

Black duck

Ringnecked duck
Estimated No. of Pairs

$23,500 \%$

$20,000 \div \div$

17,500

Unknown

5,000

Source: Bellrose, 1976

*Waterfowl biologists at Michigan DNR believe this figure to be 40,000 .

**This figure is also felt to be somewhat underestimated.

Waterfowl breeding in the coastal wetlands is significant because birds produced locally increase the success of hunters within the state as well as that of other hunters in nearby states. It has been estimated that between 25 and 40 percent of Michigan's annual harvest consists of ducks produced within the state (personal communication, Edward Mikula). Banding data indicated that 40 percent of all mallards (Greis, 1971, p. 32) and 82 to 95 percent of all wood ducks (Bowers and Martin, 1975, p. 314) shot annual1y 
in Michigan are reared within the state. Using the 19711975 average duck kill as a base, it is shown in Table 24 that state-produced mallards and wood ducks alone comprise 22 percent of the total duck harvest.

TABLE 24

ESTIMATE PROPORTION OF MICHIGAN'S ANNUAL DUCK HARVEST WHICH DERIVES FROM STATE-REARED WATERFOWL

1971-1975 average duck harvest in Michigan was 358,280 . If one assumes that 30 percent of ducks were state produced, then:

$$
\begin{array}{r}
358,280 \\
\mathrm{X} \quad .30 \\
\hline 107,484
\end{array}
$$

$\%$ of Total \% Reared No. Locally Produced Species Duck Harvest in Michigan harvested in Michigan Mallard 31 40 44,430 Wood Duck

11

89

35,080

TOTAL

79,510

Source: Martz, 1976; and Table 25.

When the species composition of Michigan's annual duck harvest is examined, one notes that mallards, scaup, wood ducks, black ducks, and teal dominate the yearly take (Table 25). In contrast to the state, the main species harvested in the coastal wetlands, as exemplified by the St. Clair Flats State Game Area data, are the mallard--76 percent of the area's kill, along with lesser numbers of black ducks, pintails and teal. In open-water areas, however, such as Sebewaing and Wildfowl Bays of Saginaw Bay, Lake St. Clair, Lower Detroit River and adjacent Lake Erie, where hunting from boats and floating blinds occurs, a majority of the duck kill are divers rather than dabbling ducks. 
TABLE 25

AVERAGE SPECIES COMPOSITION OF RETRIEVED DUCK SAMPLE STATE AVERAGE (1965-1974) vS. ST. CLAIR FLATS SGA (1974-1975)

\begin{tabular}{|c|c|c|c|c|}
\hline \multirow[b]{2}{*}{ Species } & \multicolumn{2}{|c|}{ State of Michigan } & \multicolumn{2}{|c|}{ St. Clair Flats SGA } \\
\hline & No. of ducks & $\%$ of Tota1 & Annual Harvest & $\%$ of Tota1 \\
\hline $\begin{array}{l}\text { Mallard, incl. } \\
\text { domestic }\end{array}$ & 29,890 & 30.48 & 4,362 & 76.30 \\
\hline Scaup (B1uebills) & 13,100 & 13.36 & 34 & 0.60 \\
\hline Wood Duck & 10,370 & 10.57 & 28 & 0.49 \\
\hline $\begin{array}{l}\text { Black duck and } \\
\text { hybrids }\end{array}$ & 7,550 & 7.70 & 498 & 8.71 \\
\hline $\begin{array}{l}\text { Green-winged } \\
\text { teal }\end{array}$ & 6,000 & 6.12 & 173 & 3.03 \\
\hline Ringed-neck duck & 5,280 & 5.38 & 78 & 1.36 \\
\hline Bufflehead & 4,580 & 4.67 & 18 & 0.31 \\
\hline Blue-winged tea1 & 4,160 & 4.24 & 71 & 1.24 \\
\hline Redhead* & 4,050 & 4.13 & 4 & 0.07 \\
\hline Goldeneye & 3,020 & 3.08 & 9 & 0.16 \\
\hline $\begin{array}{l}\text { Baldpate (Am. } \\
\text { widgeon) }\end{array}$ & 2,540 & 2.59 & 138 & 2.41 \\
\hline Canvasback* & 1,640 & 1.67 & 0 & 0.00 \\
\hline Pintail & 1,620 & 1.65 & 242 & 4.23 \\
\hline Mergansers & 1,240 & 1.26 & 19 & 0.33 \\
\hline Scoter & 740 & 0.76 & 0 & 0.00 \\
\hline Ruddy duck & 700 & 0.71 & 3 & 0.05 \\
\hline old squaw & 640 & 0.65 & 0 & 0.00 \\
\hline Gadwa11 & 610 & 0.62 & 30 & 0.53 \\
\hline Shoveler & 350 & 0.36 & 10 & 0.18 \\
\hline TOTAL & 98,080 & $100.00 \%$ & 5,717 & $100.00 \%$ \\
\hline $\begin{array}{l}\text { Source: Mississi } \\
\text { Pospicha }\end{array}$ & $\begin{array}{l}\text { ippi F1yway } \mathrm{F} \\
\text { a1 (1975 and }\end{array}$ & $\begin{array}{l}\text { trieved Harv } \\
\text { 974). }\end{array}$ & st Data, 1965, & 1974; and \\
\hline
\end{tabular}

In Ohio, mallards, black ducks, wood ducks, and blue-winged teal comprise 75 percent of the annual duck harvest 
(Bednarik, 1976, p. 4). A comparison of Table 22 with Table 25 reveals that the coastal wetlands constitute both nesting habitat and shooting grounds for several of Michigan's important game ducks, especially mallards and black ducks.

One index of the nesting value of a coastal wetland is the density of nesting waterfowl per areal unit. Some of the available duck nesting densities derived from ground surveys are presented in Table 26. (Aerial surveys, in comparison, frequently underestimate actual nesting densities, especially of wood ducks). Although an average density of 83 nesting pairs per square mile was determined, the standard deviation is high with densities ranging from 18 to 169 /square mile. Given 105,855 acres of coastal wetlands in Michigan (Table 2) and a duck nesting density of 83 breeding pairs per square mile, then there may be 14,000 breeding pairs of ducks in the coastal wetlands. Likewise, the acres per nesting pair of ducks varies considerably about its mean of 12 acres per pair.

TABLE 26

DUCK NESTING DENSITIES IN COASTAL WETLANDS OF MICHIGAN, 1951-1966

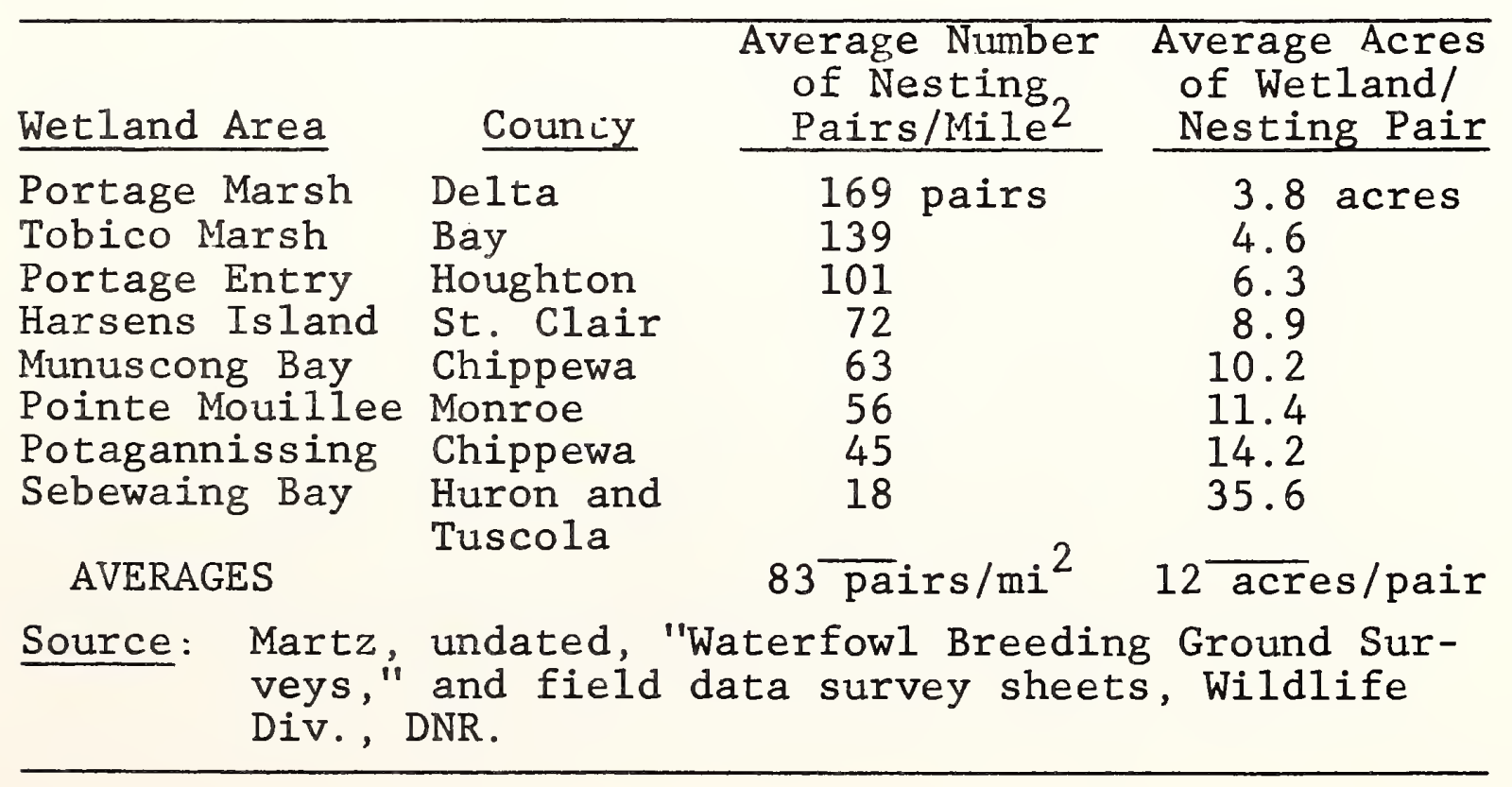


Although the data are not complete (Table 26), two coastal wetlands--Portage and Tobico marshes, appear highly productive. Also, under controlled level impoundment, an average of 134 pairs per square mile was obtained during 1969 and 1973 at Nayanquing Point State Game Area. Unrefined sampling techniques as well as disturbance by humans may explain the apparent low densities of nesting ducks on Harsens Island and in the coastal marshes of Mon roe County (Miller, 1943, p. 85, personal comnunication, Pospichal) Because broods are difficult to observe among the marsh vegetation, available brood count data are sparse. Table 27 represents some of the early extant data.

TABLE 27

DENSITY OF DUCK BROODS IN MICHIGAN WETLANDS, 1949

\begin{tabular}{|c|c|c|c|}
\hline Wetland Area & County & $\begin{array}{l}\text { No. of Broods } \\
\text { Per Sq. Mile } \\
\end{array}$ & $\begin{array}{c}\text { No. of } \\
\text { Duck Species }\end{array}$ \\
\hline Portage Marsh & Delta & 116.0 & 4 \\
\hline Dead Stream* & Ros common & 80.0 & 4 \\
\hline Hayward Marsh* & Menominee & 72.7 & 2 \\
\hline $\begin{array}{l}\text { Thunder Bay } \\
\text { River* }\end{array}$ & Alpena & 12.5 & 1 \\
\hline Nayanquing Point & Bay & 11.3 & 6 \\
\hline Sebewaing Bay & Huron & 8.7 & 4 \\
\hline Portage Marsh & Houghton & 5.4 & 2 \\
\hline Kalamazoo River* & Allegan & 3.7 & 3 \\
\hline AVERAGES & & 39 & 3.3 \\
\hline Source: Miller & (1949). & & \\
\hline *Inland Marshes & & & \\
\hline
\end{tabular}

Portage Marsh, again, stands out as a most productive wetland. Some of the coastal wetlands, e.g., Nayanquing Point and Portage Marsh, exhibit considerable species diversity among the nesting pairs compared to inland 
wetlands. Although these data suggest an average of 39 broods per square mile and a species diversity of 3.3 species per wetland area, more sampling should be carried out to derive nesting standards for evaluation purposes. The actual production of waterfowl young per areal unit of wetland is a more useful measure of productivity than nesting densities. Table 28 contains field biologists' estimates of the production of ducklings in the

\section{TABLE 28}

\section{BIOLOGISTS' ESTIMATES OF NESTING PAIRS AND DUCKLING} PRODUCTION IN MICHIGAN COASTAL WETLANDS, 1975

\begin{tabular}{|c|c|c|c|c|}
\hline Wetland Area & County & $\begin{array}{l}\text { Potential No. } \\
\text { of Young/ } \\
\text { Wetland Acre }\end{array}$ & $\begin{array}{c}\text { No. of } \\
\text { Nesting } \\
\text { Pair/Sq. Mile }\end{array}$ & $\begin{array}{l}\text { Wetland } \\
\text { Acres } \\
\text { Per Pair } \\
\end{array}$ \\
\hline Salt River & Macomb & 4.0 & 430 & 1.5 \\
\hline Nayanquing Pt. & Bay & 1.6 & 200 & 3.2 \\
\hline Huron Pt. Marsh & Macomb & 1.3 & 130 & 4.9 \\
\hline St. Johns Marsh & St. Clair & 0.98 & 102 & 6.3 \\
\hline Arcadia Marsh & Manistee & 0.98 & 82 & 7.8 \\
\hline Harsens Island & St. Clair & 0.96 & 103 & 6.2 \\
\hline Quanicassee WA & Bay & 0.89 & 113 & 5.7 \\
\hline Tobico Marsh & Bay & 0.80 & 100 & 6.4 \\
\hline Saginaw Bay Shore & Tuscola & 0.65 & 75 & 8.5 \\
\hline Old Rifle R. Lodge & Arenac & 0.40 & 60 & 10.7 \\
\hline Quanicassee SGA & Tuscola & 0.14 & 13 & 49.2 \\
\hline Misery Bay & Alpena & 0.12 & 12 & 53.3 \\
\hline AVERAGES & & 1.1 & 118 & 14 \\
\hline
\end{tabular}

Source: Martz, "The Mississippi Flyway Waterfowl Habitat Reconnaissance, 1976," Data Sheets.

coastal wetlands of Michigan. Additional data regarding the number of ducks and coot broods reared in the Erie Shooting and Fishing Club Marsh for the period 1957-1968 have been published, but it is not possible to derive 
density statistics (Hunt and Mickelson, 1976, p. 37). An average of 1.1 ducklings per acre was generated from the data in Table 28. Based on the nesting pair densities presented in Table 26 , the duckling production in Table 28 appears to be a maximum potential figure as opposed to a realistic estimate of actual production. A current estimate of nest success for dabbling ducks in Michigan is 40 percent, while along the Lake Erie marshes where nest terminations due to seiche floods and other causes are common, a nest success of 20 percent may be realistic (Martz, 1977, p. 11). If one assumes six young per brood (Miller, 1949, then:

83 pairs/sq. mi. $X 0.40$ nest success $=33$ successful nests/sq. mile

33 nests X 6 young per brood $=198$ ducklings $/ \mathrm{sq}$. mile.

A production of 0.31 ducklings/acre/year for the wetlands (198 ducklings per square mile divided by 640), does not compare well with the 1.1 contained in Table 28 . However, if a 100 percent nesting success is assumed, then the estimated number of ducklings produced per acre appears correct. Therefore, the biologists' estimates of nesting pair density and production of ducklings per acre may be too high. During his 1962-1963 study, Thompson (1964) found in the 729-acre Ottawa Shooting Club Marsh along Lake Erie in northwest Ohio, a total of 197 flying ducklings, or 0.27 flying ducklings per acre. On the other hand, Miller's data from Table 27, when analyzed, reveals an average production of 0.36 ducklings per acre. Thus, an average productivity of 0.31 ducklings per acre is probably a representative statistic for Michigan's coastal wetlands.

Although each waterfowl species has its own nesting habitat preferences, four general components of a nesting territory include: nesting cover, food for the entire brood, open water, and loafing sites (Andrews, 1952, p. 141). 
Some coastal wetlands (e.g., Dickinson Island in Lake St. Clair) contain both grassy meadow and deep-water marshes for nesting of dabbling and diving ducks. The Lake St. Clair wetlands as well as those protected by coastal barriers (e.g., Tobico Marsh), or artificial dikes (e.g., Erie Shooting (lub) are secure from large seiches and other sudden water level fluctuations which characterize the coastal wetlands. Many game managers of managed wetlands, e.g., at Fish Point, not only dike the marshlands but strive to increase the linear extent of the marsh-open water boundary or 'edge' by opening up the dense cattail stands, thereby increasing the number of potential nesting territories.

Diking and other management practices can greatly improve waterfowl production in the coastal wetlands. Using artificial dikes, Ohio hopes to reclaim from Lake Erie 1,857 acres of coastal marshland which were recently washed out by wave action (Weeks, 1974, p. 8). In addition to protection from high-water conditions, as in the case of the diked marsh at Pointe Mouillee, dikes were also constructed to impound water during low

lake level periods. Succession during low-water conditions often results in dense stands of emergent vegetation which, in turn, reduces the availability of preferred food items and nesting habitat. The abandonment of nesting territories by breeding ducks in the managed Ottawa Shooting Club Marsn of northern Ohio following artificial water drawdown substantiates the adverse impact of low water-level conditions on duck productivity (Thompson, 1964, p. 75). Finally, the erection of nesting boxes, nesting structures, and artificial nesting islands (Martz, 1977, p. 10), as well as predator control (Urban, 1968, p. 70) may significantly increase nesting success and production of 0.50 ducklings per acre, which was estimated at Nayanquing Point during 1969 and 1973, may be feasible 
in the coastal wetlands when Great Lakes water levels approximate average conditions.

If the state of Michigan has 105,855 acres of coastal wetlands (see Chapter 2), it is possible to estimate the total annual duck production per acre. Assuming 0.31 flying ducklings per acre, then a total annual production of 32,815 ducks is obtained for the coastal wetlands. This coastal production may contribute 14 percent of the state's total production. A total duck production of 240,000 was estimated by assuming that each year Michigan has 100,000 breeding pairs (see Table 23), that the nesting success rate is 40 percent and that six young are produced per brood (see earlier discussion, this Chapter).

Assuming that there are 32,815 ducks produced in the coastal wetlands and that 40 percent of these ducklings are mallards (see earlier discussion), then a total of 13,125 flying mallard ducklings may be produced within the coastal environments. This would amount to an estimated 15 percent of the state's total annual mallard production, provided there were 40,000 breeding pairs of mallards. Thus, the coastal wetlands, particularly if properly managed, are most productive waterfowl breeding areas.

A survey conducted during the 1952-1955 period revealed that Michigan possessed 310,500 acres of wetlands which were considered to be of high value to waterfowl (Miller, 1958, p. 1). In 1976, a study indicated that the state had 259,000 acres of wetland and adjacent uplands which served as high quality waterfowl habitat (Martz, 1976, p. 1). Approximately 212,000 acres of the 259,000 acres were considered of importance to waterfowl breeding (ibid., p. 1). Excluding land contained within public refuges and wildlife areas, some of this prime breeding ground is currently being threatened by private development. The threatened coastal wetlands are indicated in Table 29. An estimated 18,362 acres of coastal breeding 
TABLE 29

WATERFOWL BREEDING HABITAT IN COASTAL WETLANDS THREATENED BY PRIVATE DEVELOPMENT WITHIN 5

YEARS, MICHIGAN, 1976

\begin{tabular}{|c|c|c|}
\hline Upper Pe & insula & \\
\hline Wetland Area & County & Wetland Acres* \\
\hline Portage Entry Marsh & Houghton & 470 \\
\hline ladstone Marsh & Delta & \\
\hline Portage Marsh & Delta & 500 \\
\hline Baie de Wasai & Chippewa & 410 \\
\hline Munuscong Bay & Chippewa & 900 \\
\hline Raber Bay & Chippewa & 300 \\
\hline Duck Bay & Mackinac & 250 \\
\hline Epoufette Bay & Mackinac & 300 \\
\hline Flowers Bay & Mackinac & 185 \\
\hline Hessel Bay (Mackinac Bay) & Mackinac & 500 \\
\hline Nuns Creek and Bay & Mackinac & 290 \\
\hline Prentiss Bay & Mackinac & 270 \\
\hline Northern Low & r Peninsula & \\
\hline Wetland Area & County & Wetland Acres* \\
\hline Squaw Bay & Alpena & 1,000 \\
\hline Cheboygan Marsh & Cheboygan & 120 \\
\hline Au Gres (Old Rifle River & Arenac & \\
\hline Lodgex* & Arenac & 1,229 \\
\hline Quanicassee Wildlife Area & Bay & 960 \\
\hline Tobico Marsh $2 x$ & Bay & 700 \\
\hline Southern Low & E Peninsula & \\
\hline Wetland Area & County & Wetland Acres ${ }^{*}$ \\
\hline Lake Muskegon Marshes & Muskegon & 4,000 \\
\hline Grand Haven River Marshes & Ot tawa & 1,200 \\
\hline Lake Macatawa Marshes & Ottawa & 210 \\
\hline Wildfowl Bay Shoreline & Huron & 400 \\
\hline Quanicassee State Game & & \\
\hline Areat* & Tuscola & 480 \\
\hline Saginaw Bay Shoreline & Tuscola & 220 \\
\hline Galien River Marsh & Berrien & 550 \\
\hline Ford Marsh & Monroe & 180 \\
\hline Port of Monroe Marsh & Monroe & 60 \\
\hline Union Camp Marsh & Monroe & 240 \\
\hline Humbug Marsh & Wayne & 180 \\
\hline Huron Point Marshes & Macomb & 380 \\
\hline Salt River Marshes & Macomb & 60 \\
\hline St. Johns Marsh & St. Clair & 1,790 \\
\hline $\begin{array}{l}\text { TOTAL } \\
\text { Source: Martz, 1976, "The }\end{array}$ & Mississippi & $\begin{array}{l}1 \overline{8}, 362 \\
\text { Flyway Waterfow1 }\end{array}$ \\
\hline Habitat Reconaiss & ice." & Flyway waleterwi \\
\hline *Development is expected & be initiat & Eed within 5 years \\
\hline $\begin{array}{rl} & (1981 \text { A.D. }) \\
* & * \text { Publicly-owned holdings }\end{array}$ & & \\
\hline & & \\
\hline
\end{tabular}


habitat are faced with some degree of residential development and other encroachment within the next five years or so. Assuming that Michigan has only 105,855 acres of coastal wetlands, then 17 percent of the total would be adversely impacted within less than a decade. In order to establish a priority system for protecting these breeding areas, the waterfowl productivity of each wetland, coastal and inland, must be determined and comparisons made.

Protecting waterfow 1 breeding areas in Michigan is important since a large and slowly increasing proportion of the state's annual duck harvest derives from state-produced young. At present, though resident breeding populations are increasing, state-produced Canada Geese probably provide less than 10 percent of the annual Canada Goose harvest in Michigan (personal comunication, Gerald Martz). The productivity of the coastal wetlands takes on greater significance when drought or wetland destruction in inland Michigan and elsewhere in North America reduces waterfow 1 breeding opportunities . VALUE OF WATERFOWL HUNTING IN COASTAL WETLANDS

The harvest of waterfowl, particularly ducks, in Michigan during the October-November hunting season is an important recreational activity (Table 30). During the period 1971-1975, an annual average of about 116,750 waterfowl hunters purchased federal duck stamps and spent an average annual total of 639,950 recreation days (average of 6.3 days per hunter). The state estimate for number of hunters in 1975 (see Table 30) is used in this report because it includes those hunters under the age of 16 not requiring a federal duck stamp and gives a closer approximation to the actual number of waterfowl hunters. 
Estimates of the annual waterfowl harvest in Michigan by the Department of Natural Resources, Wildlife Division, exceeds that of the U. S. Fish and Wildlife Service. For example, the state Department of Natural Resources estimated the average annual retrieved duck harvest during 1971-1975 to be 597,966, whereas data from the Fish and Wildlife Service suggests an average of 358,284 retrieved birds (U. S. Fish and Wildlife Service, 1976). The state and federal estimates are arrived at using different sampling techniques which may account for

TABLE 30

ANNUAL WATERFOWL HARVEST IN MICHIGAN, 1971-1975, DNR ESTIMATES

\begin{tabular}{|c|c|c|c|c|c|}
\hline Year & $\begin{array}{l}\text { Number of } \\
\text { Hunters* }\end{array}$ & $\begin{array}{c}\text { Number of } \\
\text { Recreation Days }\end{array}$ & $\begin{array}{l}\text { No. of } \\
\text { Ducks }\end{array}$ & $\begin{array}{l}\text { No. of } \\
\text { Geese }\end{array}$ & $\begin{array}{l}\text { No. of } \\
\text { Coots }\end{array}$ \\
\hline 1975 & 118,500 & $1,205,630$ & 651,860 & 32,430 & 32,450 \\
\hline 1974 & 116,780 & $1,200,980$ & 615,440 & 43,090 & 48,280 \\
\hline 1973 & 116,310 & $1,324,930$ & 598,290 & 38,610 & 54,260 \\
\hline 1972 & 109,130 & $1,120,040$ & 530,960 & 25,550 & 34,560 \\
\hline 1971 & 123,000 & $1,311,050$ & 593,280 & 38,000 & 87,750 \\
\hline AVG. & 116,744 & $1,232,526$ & $597,966 * *$ & 35,536 & 51,500 \\
\hline
\end{tabular}

Source: Michigan DNR Biennia1 Reports.

*Includes waterfow 1 hunters under the age of 16 not requiring a federal duck stamp.

**U. S. Fish and Wildlife Service data for 1971-1975 reveals an average of 358,284 ducks.

the variability of the harvest figures. The more conservative Fish and Wildlife Service estimate of the average duck harvest of 358,284 retrieved birds, excluding cripple losses, will be utilized in this report.

Long-term waterfowl harvest data are available for the managed state game areas, including Fish Point, Pointe 
Mouillee, and St. Clair Flats, as well as from the Erie Shooting Club. As an example, during the past few years, the annual kill of ducks at Fish Point $(2,475$ acres $)$ and St. Clair Flats (2,600 acres of managed wetland) has averaged about 5,000 and 6,000 ducks, respectively (Pospichal, 1975; Jarvis, 1975a). Because of extensive coastal erosion resulting in the loss of the marsh habitat, the managed public hunt at Pointe Mouillee has been temporarily discontinued. For most private coastal wetlands, however, the harvest data have not been collected for the entire season or are badly fragmented.

Data are not readily available to determine the proportion of the annual waterfow 1 harvest in Michigan which occurs in the coastal wetlands. However, the proportion may be quite high because several of the main fall migration concentration areas are located within coastal wetlands (see Figure 20). A comparision of the harvest in 11 coastal counties with that taken in the remainder of the state reveals that 39 percent of the waterfowl kill (94,188 divided by 240,965$)$ derives from counties with extensive coastal wetlands (Table 31). Because dabbler ducks, not divers, are commonly harvested in the coastal wetlands, the proportion of the coastal wetland waterfowl harvest is estimated to be 21 percent of the state total (50,735 divided by 240,965 ).

The top six counties in the entire state with the highest waterfowl harvest, in descending order, are st. Clair, Saginaw, Huron, Monroe, Tuscola and Bay counties. Among this group of counties, only Saginaw is an inland county. It should be pointed out that all six counties contain large state holdings and public waters where public hunting occurs.

If 21 percent of Michigan's annual duck harvest occurs in coastal wetlands, then approximately 75,240 ducks are taken yearly from the coastal wetlands. This estimate 
TABLE 31

AVERAGE DUCK HARVEST IN THE COASTAL COUNTIES

OF MICHIGAN BY COASTAL COUNTY IN MICHIGAN, 1961-1970 ANNUAL AVERAGE, U.S.F. AND W.S. ESTIMATES*

\begin{tabular}{|c|c|c|c|}
\hline \multicolumn{4}{|c|}{ Upper Peninsula } \\
\hline County & Dabblers & Divers & Total \\
\hline Chippewa & 1,376 & 3,838 & 5,214 \\
\hline Delta & 3,412 & 1,337 & 4,749 \\
\hline Mackinac & 1,334 & 3,497 & 4,831 \\
\hline Subtotal & 6,122 & 8,672 & 14,794 \\
\hline \multicolumn{4}{|c|}{ Lower Peninsula } \\
\hline County & Dabblers & Divers & Total \\
\hline Alpena & 670 & 439 & 1,109 \\
\hline Arenac & 1,628 & 1,047 & 2,675 \\
\hline Bay & 7,681 & 2,987 & 10,668 \\
\hline Cheboygan & 440 & 641 & 1,081 \\
\hline Huron & 7,383 & 8,170 & 15,553 \\
\hline Monroe & 8,239 & 2,565 & 10,804 \\
\hline Tuscola & 7,887 & 3,111 & 10,998 \\
\hline St. Clair & 8,475 & 7,951 & 16,426 \\
\hline Wayne & 2,210 & 7,870 & 10,080 \\
\hline Subtotal & 44,613 & 34,780 & 79,393 \\
\hline \multicolumn{3}{|c|}{ Lower Peninsula and U.P. Total } & 94,187 \\
\hline \multicolumn{4}{|l|}{$\begin{array}{l}\text { Totals for } \\
\text { Non-Coastal } \\
\text { Michigan }\end{array}$} \\
\hline Counties & 102,581 & 44,196 & 146,777 \\
\hline \multicolumn{4}{|c|}{ 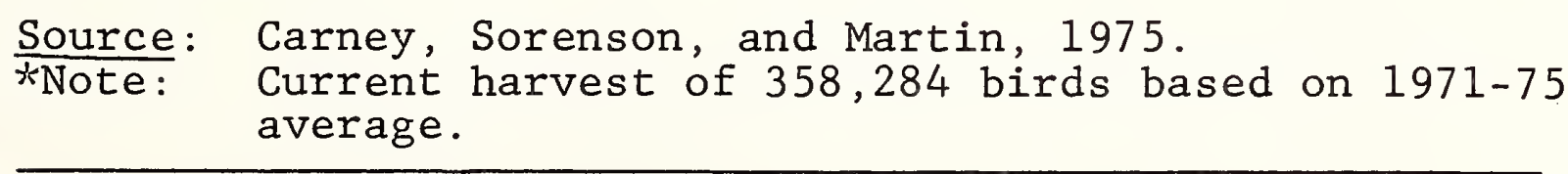 } \\
\hline
\end{tabular}

was obtained by multiplying 0.21 times 358,284 birds (the U.S. Fish and Wildlife Service average for 1971-1975; see footnote, Table 30). According to the U.S. Fish and Wildlife Service harvest data, including ducks, geese and coots, an estimated 85,987 waterfow1 were taken from the coastal wetlands $(0.21 \times 409,460$ birds $)$. 
Although Michigan has approximate1y 116,750 waterfowl hunters annually (Table 30, DNR data), there exists a substantial number of latent or potential hunters who do not participate because of a lack of accessible quality hunting. As evidenced by the popularity of duck shooting clubs which trace back to the mid-1800's, Michigan has long enjoyed a tradition of quality duck hunting.

Today the prospective hunter, particularly from metropolitan southeastern Michigan, usually applies for a reservation at a public game area because permission from private shooting clubs or owners of the few remaining wetlands is difficult to obtain. Most hunters want a reservation for the opening day and frequently for the first or second weekend of the hunting season in selected wetland areas.

Some concept of the unsatisfied waterfowl hunting demand may be obtained by comparing the number of applicants for reservations at the public game area to the number of available blinds or hunting areas. Although little of the existing raw data have been summarized, some preliminary data are presented in Table 32. For the three public game areas, which are located within coastal wetlands, there was a total of 13,450 applicants, but only 3,475 possible reservations. Each application represents a potential party of 2.5 people, and each reservation will accommodate a party of 2 or 3 hunters. The data in the table indicate that only 26 percent of the applicants could be served. It is realized that many hunters apply for reservations at more than one public shooting area. Nevertheless, the disparity between applicants and available reservations, especially on opening day, suggests that there exists a large unsatisfied demand for quality waterfowl hunting.

A study by the Great Lakes Basin Commission (1975) examined the waterfowl hunting demand by planning subbasin in Michigan. The Commission's data indicate that in each of the seven planning sub-basins which comprise the state, there is a projected increase in hunters, but 
崖

崖

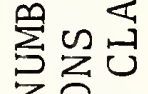

눙

눈

क्ति

嵒昌。

至出界

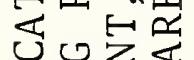

N口z台

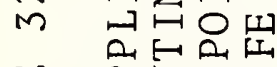

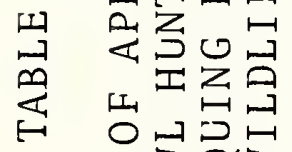

궁웅

비논디

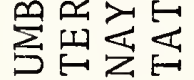

它战

山茴出

牙古

중요눈

穴完击

$<$ 业

¿

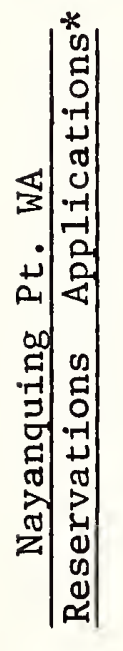

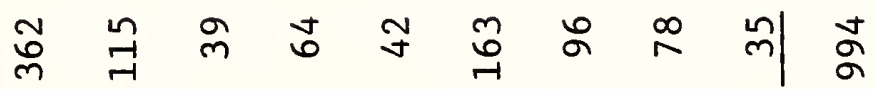

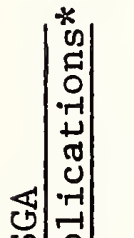

ल न न

(1)

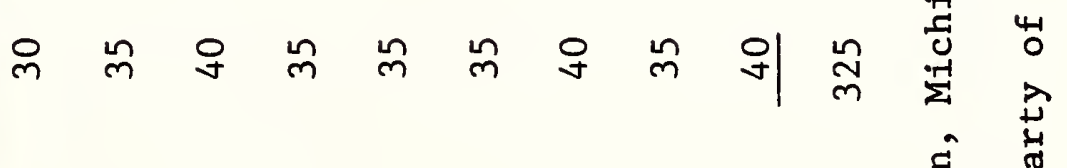

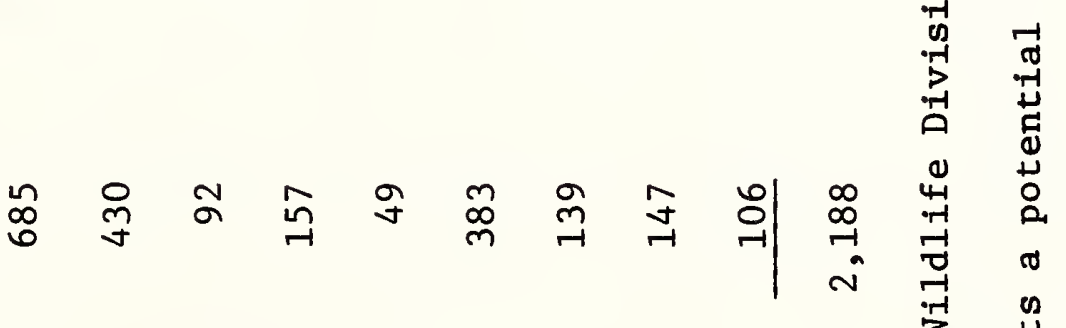

हี 预

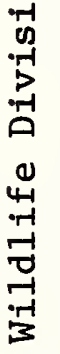

苟

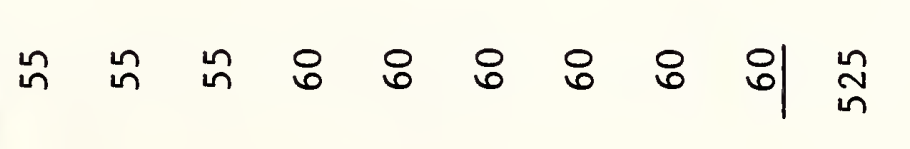

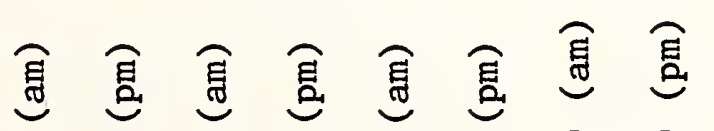

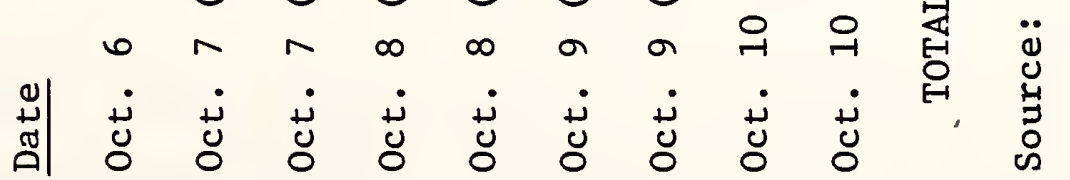


a projected decrease in acres of wildlife habitat and a decrease in potentially huntable land (Great Lakes Basin Comm., 1975c, p. 29, 73 and 100). Similarly, a study which provides some data on the southeastern corner of Monroe County reveals that wildlife in North Maumee Bay are suffering from a degraded and decreasing habitat base. Besides the fact that degraded habitat decreases a person's desire to hunt, future waterfowl hunting opportunities in the North Maumee Bay area are limited due to restricted access, poor water quality, lack of supportive facilities, and vandalism (Great Lakes Basin Comm., 1976. p. 3-8 and 3-9). A small increase in the number of hunters over time places more pressure on the resource base.

Waterfowl hunting and the game harvested in coastal wetlands contribute materially to the economy of Michigan. Preliminary estimates for 1977, based on the 1970 National Survey of Hunting and Fishing (U. S. Dept. of Interior, 1972), indicates that each waterfowl hunter spent on the average $\$ 130.25$ on equipment, licenses, transportation, and so forth. This figure was obtained by multiplying the 1970 annual hunter expenditure of $\$ 84.47$ times 1.542, which is the cost-of-living increase factor for Detroit, Michigan (personal communication, Bob Craig).

Although most waterfowl hunters orginate from rural areas and hunt in nearby counties, hunters from Detroit, Lansing, Grand Rapids and Flint often travel considerable distances to their shooting grounds. Because the transportation component of the estimated annual waterfow 1 hunter expenditures is less than $\$ 5.00$, it is believed that an economic evaluation based on annual expenditures may yield conservative values. For example, at Magee Marsh of northern Ohio, the value of a goose hunting day or trip is valued at $\$ 9.73$ (Ohio Div. of Wildlife, 1976). Nevertheless, because of ease of calculation, average annual waterfowl expenditures will be employed to estimate the value of waterfowl hunting. 
Utilizing the estimated 1977 annual waterfowl hunter expenditure value of $\$ 130.25$, Michigan's waterfowl hunters contribute to the state economy as follows:

$$
\begin{aligned}
116,750 & \begin{array}{l}
\text { Number of Waterfowl Hunters in } \\
\text { Michigan, 1971-75 Average }
\end{array} \\
\text { X } 130.25 & \text { Estimated 1977 Hunter Expenditures } \\
\$ 15, \overline{206,687} &
\end{aligned}
$$

As the above calculation illustrates, waterfowl hunting in Michigan contributes an estimated \$15.21 million annually. If data on number of hunters and distance travelled were available for each coastal wetland, then the economic importance of waterfowl hunting could be determined and protection priorities established. Further, if latent demand were included (see Table 32), the total annual value of waterfowl hunting in Michigan may be at least double, therefore equal to $\$ 30$ million or more.

The meat contained in the waterfowl carcasses is also important because many families, particularly in rural areas, supplement their diet with wild game. Further, in most instances, except at game areas with a cropping program, the waterfowl are utilizing food resources which man is not effectively exploiting. Therefore, the game can be regarded as a "free" resource. The economic value for 1975 of Michigan's annual waterfowl harvest in terms of carcasses is indicated below. A cost-

\begin{tabular}{|c|c|c|c|c|}
\hline & Annual Harvest* & $\begin{array}{c}\text { Average } \\
\text { Weight }\end{array}$ & $\begin{array}{c}\text { Carcass } \\
\text { Value } \\
\end{array}$ & $\begin{array}{l}\text { Total } \\
\text { Value } \\
\end{array}$ \\
\hline Ducks & 358,284 & 1 lbs. & $\$ 1 / 1 b$ & $\$ 358,284$ \\
\hline Coots & 29,575 & 1 lbs. & $\$ 1 / 1 b$. & 29,575 \\
\hline Geese & 21,601 & $41 \mathrm{bs}$. & $\$ 1 / 1 b$. & 86,404 \\
\hline TOTALS & 409,460 & & & $\$ 474,263$ \\
\hline
\end{tabular}
of-living factor of 1.129 was employed (personal communication, Bob Craig) to project the total 1975 carcass value of $\$ 474,263$ to a total 1977 value of $\$ 535,443$.

Source: Current Files, Wildlife Div., Michigan DNR. *U.S. Fish \& Wildlife Service figures of 1975 were used. 
If we sum the total average annual hunter's expenditures and the value of the carcasses for the year 1977, then the total economic value of Michigan's waterfow 1 hunting is $\$ 15.74$ million. In terms of waterfow 1 harvested, waterfowl hunting is worth $\$ 37.79$ per bird (obtained by dividing 409,460 waterfowl into the total value of $\$ 15,742,130)$.

During the 1971-1975 interim, an average of approximately 116,750 people (see Table 30) hunted waterfowl in Michigan. Data as to where this hunting activity occurred are not available. However, by comparing the waterfow 1 harvest from coastal counties, where several large coastal public shooting areas have been established, with that harvested from the entire state, it was estimated that 21 percent of the annual duck kill derives from the coastal wetlands. Further, if 21 percent of Michigan's waterfowlers hunt in the coastal wetlands, this accounts for some 24,518 hunters $(116,750 \times 0.21=24,519)$. If an average waterfowl hunter spends $\$ 130.25$ annually, then the coastal wetlands provide an annual hunter expenditure value of $\$ 3.19$ mil1ion $(24,518 \times \$ 130.25=\$ 3,193,470)$. When carcass values are included $(\$ 535,443 \times 0.21=$ $\$ 112,443)$, the total annual return from waterfowl hunting amounts to $\$ 3,305,913$. Given 105,855 acres of coastal wetland, the average annual value per wetland acre is $\$ 31.23$ (i.e., $\$ 3,305,913$ divided by 105,855 acres).

other economic techniques, for example, methods based on opportunity costs or on the willingness of participants to pay, may yield values which exceed that of the above analysis. Other values, including the harvest of Michigan reared birds in other states, in addition to those estimated above, may also increase the value of waterfow 1 hunting. However, it is felt that economic value of waterfowl hunting as determined herein using average annual hunter expenditures and carcass values yield a simple, yet reasonable economic estimate. 
CHAPTER FOUR

VALUE OF COASTAL WETLANDS TO FURBEARERS

In this chapter the value of coastal wetlands with regard to furbearing animals is presented. Raccoon and muskrat generate the largest trapping revenues, followed by red fox, coyote, beaver, mink and others (Table 33). Because of changes in licensing, the 1970-71 trapping season was the last year when reliable data on the number of trappers on a state level were available. During the winter trapping seasons between 1956-1976, Michigan averaged 5,560 trappers (Jenkins, 1977, p. 40). As revealed in Table 33, muskrat trappers outnumber other trappers. Although the muskrat is the most abundant furbearer, a licensed trapper will trap other furbearers as well. Therefore, the total number of trappers in Table 33 is not an accurate estimate of the total number of trappers, but rather represents a "doubling up" of trappers.

It must be noted that the value of furbearers is extremely variable from year to year. As noted in Table 33 for example, the mean value of raccoons for 1971-1972 is $\$ 4.00$. Based on the 28th Biennial Report for 19751976 (Jenkins, in press, p. 38), the average pelt price of raccoons ranges from $\$ 25$ to $\$ 30$. Similarly, the muskrat pelt value has increased significantly from \$1.75 to $\$ 2.50-\$ 3.00^{1}$ during the same time period (ibid., p. 38). MUSKRAT VALUE

The principal mammal inhabiting Michigan's coastal wetlands is the muskrat. Based on its feeding and lodging habits, a muskrat density per unit of coastal wetland can be determined. The literature and statistical data of

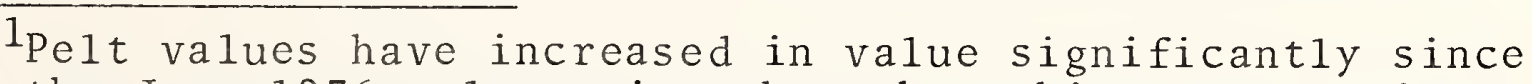
the June 1976 values given here but this conservative value is used until a definite trend of higher pelt prices is established. 
TABLE 33

FURBEARERS, TRAPPERS AND FUR VALUE IN MICHIGAN (1971-1972)

\begin{tabular}{|c|c|c|c|c|}
\hline Species & Trappers & Harvest & Mean Value $(\$)$ & Pelt Value (\$) \\
\hline Muskrat & 6,240 & 348,400 & 1.75 & 609,700 \\
\hline Mink & 2,580 & 10,050 & 10.00 & 100,000 \\
\hline Raccoon & 2,840 & 13,350 & 4.00 & 929,600 \\
\hline Oppossum & 1,630 & 8,690 & .50 & 4,345 \\
\hline Badger & 350 & 400 & 4.00 & 1,600 \\
\hline Skunk & 1,100 & 6,350 & 2.00 & $12,700^{\circ}$ \\
\hline Weasel & 480 & 980 & 1.00 & 980 \\
\hline Coyote & no data & 65,530 & 3.00 & 196,590 \\
\hline Fox & no data & $32,150 *$ & 8.00 & 257,200 \\
\hline Otter & 2,318 & 584 & 25.00 & 14,600 \\
\hline Beaver & 2,318 & 7,212 & 20.00 & 144,240 \\
\hline TOTAL & & & & $2,272,055$ \\
\hline Source: & \multicolumn{4}{|c|}{ DNR, 26th Biennial Report 1971-1972. } \\
\hline
\end{tabular}

the DNR reveal that the distribution of this furbearer is greatest in the southern half of the lower peninsula (Zone 3). Table 34 shows that between 1967-68 and 1970-71 an estimated total of 962,700 muskrats were trapped in Zone 3 compared to 166,700 and 233,530 in Zone 1 and Zone 2 respectively. Approximately 68 percent of the muskrat catch is from wetlands in the southern half of the lower peninsula.

Baumgartner (1942, p. 30) who surveyed 33 muskrat sites in the state, concluded that habitats on streams in Zone 1 and 2 are exceptionally poor except at their sources and at their mouths because of food scarcity. He also evaluated marsh habitats and determined that all coastal habitats investigated support better than average 
TABLE 34

MUSKRATS HARVESTED BY TRAPPERS, 1967-1971 IN MICHIGAN

\begin{tabular}{|c|c|c|c|c|}
\hline Area & $1967-68$ & $1968-69$ & $1969-70$ & $1970-71$ \\
\hline Zone 1 & 27,320 & 40,400 & 49,120 & 49,860 \\
\hline Zone 2 & 44,720 & 58,060 & 64,490 & 66,260 \\
\hline Zone 3 & 162,550 & 174,940 & 292,930 & 232,280 \\
\hline TOTAL & 234,590 & 273,400 & 406,540 & 348,400 \\
\hline Source: & \multicolumn{4}{|c|}{$\begin{array}{l}\text { Hawn, Michigan Furbearer Catch by Trappers, 1970- } \\
\text { 71, DNR, Research and Development Report No. } \\
\text { 257, Jan., 1972. }\end{array}$} \\
\hline
\end{tabular}

muskrat populations. These exceptional habitats were:

Muskegon Lake

Little Bay de Noc

Pere Marquette River

Portage Marsh

Manistee River

Munuscong Bay

Arcadia Marsh

Saginaw Bay

Big Bay de Noc

Lake Erie Marshes

The food supply of muskrats may be diverse, especially during times of stress. Baumgartner (ibid., p. 15) has identified 34 food items of the muskrat in Michigan. The preferred food is cattail, bulrush, and blue joint grass. Based on the literature, the most common food type is cattail and in some cases bulrush, (Bellrose and Low, 1943; Mathiak and Linde, 1954; and Kadlec and Wentz, 1974). Panzner concluded that Type 4 and Type 5 wetlands are the optimum habitats in terms of food and cover for Michigan's muskrats (1955, p. 9). Type 4 wetlands are characterized by cattails, reeds and other emergent vegetation. In open areas, aquatics such as pondweeds, naiads, watermilfoils, and waterweeds are abundant. According to Shaw and Fredine (1956, p. 21), the Type 4 wetland is an "Inland deep fresh water marsh." Type 5 wetlands are "Inland open fresh water marshes usually less than 10 feet in depth and 
bordered by emergent vegetation (ibid., p. 21-22). The deeper waters of the Type 5 wetlands are colonized by pondweeds and other aquatics. Shaw and Fredine also note that these two wetland types are more commonly used by muskrats than any other furbearer (ibid., p. 42).

Most of the muskrat data in the past have been collected and tabulated on a county by county basis. Table 35 represents the muskrat in eight coastal counties in southeastern Michigan (Zone 3) over a six-year period. The muskrat habitat in these counties is primarily in the coastal zone. What may be concluded from Table 35 is that muskrat populations are high in coastal wetlands and the number of muskrats generally increases from north to south.

TABLE 35

MUSKRAT TAKE IN SELECTED COUNTIES OF SOUTHEASTERN MICHIGAN, 1965-1970

\begin{tabular}{|c|c|c|c|c|c|c|c|}
\hline County & 1965 & 1966 & 1967 & 1968 & 1969 & 1970 & Average \\
\hline Arenac & 854 & 11 & 1,210 & -- & 786 & 1,750 & 769 \\
\hline Bay & 1,718 & 1,485 & 7,878 & 18,482 & 27,158 & 11,307 & 11,338 \\
\hline Tuscola & 919 & 225 & 3,738 & 5,110 & 2,104 & 10,603 & 3,783 \\
\hline Huron & 2,702 & 8,000 & 16,386 & 10,103 & 14,759 & 8,740 & 10,115 \\
\hline St. Clair & 2,675 & 15,515 & 24,335 & 13,395 & 16,063 & 30,350 & 18,722 \\
\hline Macomb & 1,272 & 4,084 & 2,658 & 5,469 & 6,012 & 3,479 & 3,829 \\
\hline Wayne & 112 & 2,700 & 392 & 1,006 & 1,484 & 1,149 & 1,141 \\
\hline Monroe & 12,155 & 18,834 & 5,185 & 15,743 & 15,811 & 8,481 & 12,702 \\
\hline Source: & $\begin{array}{l}\text { Data summ } \\
\text { DNR. }\end{array}$ & arized by & Ryel, & Office of & E Surve & $S$ and $S$ & istics, \\
\hline
\end{tabular}

A survey similar to that presented in Table 35 was taken from 1950 through 1958. In the same eight county area the 1950-1958 survey noted that the muskrat take was largely within two miles of the Great Lakes' shorelines (Permanent File, 1959, Wildlife Division, DNR). 
That survey, which included the urbanized areas of southeastern Michigan, concluded that 8.5 percent of Michigan's total area produces 11 percent of the state's muskrats. Consistently outstanding harvests reflected in both surveys included the wetlands of St. Clair and Monroe Counties.

The coastal wetland acreage of the selected counties (see Figure 1) may be tabulated and compared to the average muskrat production of the preceding table. As noted in Table 36 below, a ratio of muskrats per acre has been determined. The "Wetland Acres" and "Cattail Acres" were obtained from the DNR Coastal Wetland Inventory (1973). The wetland acreage for Macomb County is probably higher than 30 acres as indicated in that report. Based on Table 5 the acreage of coastal wetland for the coastal zone (Salt River and Clinton River areas) totalled 590 acres in 1973. If the total take in Macomb County is 3,829 "rats," the take per acre is 6.48 "rats." Based on our investigations most of the acreage in coastal Macomb County is in cattail. Therefore, it will be assumed that all 590 acres are colonized by cattails. As discussed in the above paragraphs, muskrats occupy and feed mainly in the cattail areas in a given wetland. ${ }^{2}$ Therefore, if the muskrats taken per acre of cattail is used the ratio increases

2 In 1973, the DNR completed a coastal wetland inventory. Basically, the acreages of different marsh vegetation, including cattails were determined. It must be noted that in 1972 when the survey was conducted, lake levels were approaching record high levels. For example, in the summer of 1972 Lakes Michigan and Huron were at an elevation of 580.3 feet, Lake St. Clair at 575.3 feet and Lake Erie at 572.4 feet. The average levels between 1900 and 1976 for Lakes Michigan and Huron, St. Clair and Erie were $578.34,573.61$ and 570.85 feet, respectively. Therefore, due to drowning, the wetland acreages may not represent "normal" conditions. 
(column 6). The average sustained muskrat take of the eight county area is 3.42 "rats" per cattail acre.

TABLE 36

MUSKRAT TAKE PER WETLAND ACRE AND PER CATTAIL ACRE IN SELECTED COUNTIES OF SOUTHEASTERN MICHIGAN

\begin{tabular}{|c|c|c|c|c|c|}
\hline \multirow[b]{2}{*}{ County } & \multirow{2}{*}{$\begin{array}{c}\text { Avg. Muskrat Take } \\
(1965-1970) \\
\end{array}$} & \multicolumn{2}{|c|}{ Wetlands } & \multicolumn{2}{|c|}{ Cattail } \\
\hline & & Acres & Take/Acre & Acres & Take/Acre \\
\hline Arenac & 769 & 4,740 & .16 & 2,850 & .27 \\
\hline Bay & 11,338 & 9,790 & 1.16 & 5,760 & 1.97 \\
\hline Tuscola & 3,783 & 5,250 & .72 & 1,130 & 3.35 \\
\hline Huron & 10,115 & 14,946 & .68 & 3,110 & 3.25 \\
\hline St. Clair & 18,722 & 15,600 & 1.20 & 4,488 & 4.17 \\
\hline Macomb & 3,829 & 590 & 6.49 & 590 & 6.49 \\
\hline Wayne & 1,141 & 1,420 & .80 & 730 & 1.56 \\
\hline Monroe & 12,702 & 6,715 & 1.89 & 1,995 & 6.37 \\
\hline
\end{tabular}

Compared to other wetlands, 3.42 "rats" per acre is a reasonably high productive average. Within Horicon Marsh of Wisconsin is a 95-acre managed marsh which produced 5.48 "rats" per acre (Mathiak and Linde, 1954, p. 11). In the Magee Marsh, which is also a controlled system, 40,000 "rats" were harvested from a 2,000-acre area (U. S. Dept. of Interior, 1967, p. 77). A muskrat take of two to six per acre is an average for many coastal wetlands of the state, whereas a sustained yield of five to six per acre is considered to be very high (personal communication, Leo Pospichal). For the purposes of this study, it will be assumed that average annual muskrat harvest from cattail marshes is 3.42 animals per acre but only 3.0 animals/. acre from the coastal wetlands in general.

If the current value of a muskrat pelt is $\$ 7.00$ (personal communication, Karl Bednarik) and the density is 3.42 muskrats per acre of cattail, the selected wetlands in southeastern Michigan have a fur value of $\$ 23.94$ per cattail 
acre. 3 The carcass value of a muskrat in 1975 was $\$ 1.50$ per "rat" ( $1 \frac{1}{2}$ pound animal $\left.x \$ 1.00 / 1 \mathrm{~b}.\right)$. Based on the 1975-1977 cost-of-1iving factor, which is 1.129 , the present carcass value of a muskrat is $\$ 1.70$ (1.5 1bs. $x \$ 1.13)$. Since the density of muskrats is 3.42 , the carcass value, per cattail acre, would be $\$ 5.81$. This means that the total average annual muskrat value per acre of cattail in the selected southeastern Michigan counties, to include fur and carcass values would be $\$ 29.75(\$ 23.94+\$ 5.81)$. The coastal cattail habitat in Michigan in 1972 totalled 30,809 acres. If the value of muskrats is $\$ 29.75$ per cattail acre, the state's muskrat value is $\$ 916,568$.

Although there is general agreement among researchers in Michigan that the muskrat population increased from north to south, there are exceptional habitats in Zone 2 (e.g., Arcadia Marsh) and Zone 1 (e.g., Munuscong Bay). Also, it has been noted by Baumgartner (1942, p. 30) that low muskrat productivity occurs between the river source and the coast. Therefore, high production may be anticipated in the coastal wetlands especially if a cattail habitat is abundant.

Because muskrats are rather omniverous herbivores and occur in most coastal wetland environments, the value of this furbearer for the coastal wetlands in general must also be estimated. Given an average annual take of 3.0 muskrats per wetland acre and a combined pelt and carcass value of $\$ 8.70 /$ animal ( $\$ 1.70$ for carcass $+\$ 7.00 /$ pe $1 t)$, muskrats generate an average annual return of $\$ 26.10 /$ wetland acre. If there are 105,855 acres of wetlands along Michigan's coasts, a total average annual value of $\$ 2,762,816$ is obtained.

${ }^{3}$ It is recognized that the current pelt price is high compared to past prices. Between 1971-1976 pelt prices ranged between $\$ 2.00$ and $\$ 3.50$. However, the quality of fur from the coastal areas is better, hence the fur prices in these areas are usually highest (personal communication, Richard Julian). 
$\underline{\text { RACCOONS }}$

As noted in Table 33, the most significant furbearer in terms of pelt value is the raccoon. The DNR data in the past were collected by zones, therefore only rough estimates of the value of the raccoon can be determined with regard to coastal wetlands. As with muskrats, the number of raccoons hunted increases from north to south (Table 37).

\section{TABLE 37}

ESTIMATED RACCOON HARVEST IN MICHIGAN, 1971-1975

\begin{tabular}{|c|c|c|c|c|c|}
\hline & 1971 & 1972 & 1973 & 1974 & 1975 \\
\hline Region 1 & 790 & 7,430 & 9,200 & 6,260 & 6,810 \\
\hline Region 2 & 33,400 & 26,580 & 44,830 & 66,460 & 66,840 \\
\hline Region 3 & 209,480 & 207,130 & 213,870 & 300,330 & 257,190 \\
\hline TOTAL & 243,670 & 241,140 & 267,900 & 373,050 & 330,840 \\
\hline Source: & $\begin{array}{l}\text { Hawn, Mi } \\
\text { DNR, Aug }\end{array}$ & $\frac{\operatorname{gan} \text { Smal }}{1976}$ & $\frac{\text { Game Kill }}{4 .}$ & Estimate & 1975, \\
\hline
\end{tabular}

In recent years with increased fur prices, the harvest for raccoons has increased. In the 1960's for example, the annual harvest totalled approximately 130,000 animals. By 1975, the harvest more than doubled. High value habitat for raccoon includes Types 2, 3, 4, 5, and 7 wetland (Table 3) for food and cover (Panzner, 1955, p. 9). These habitats as classified by Shaw and Fredine (1955, p. 21) range from Type 2-Inland fresh meadows (i.e., sedges, grasses and various broad-leaved plants) to all habitats normally occupied by muskrats. Also included are wooded swamps which may occupy portions of drowned estuaries in coastal western Michigan. The most intensive use by raccoons is the Type 2, 3, 6 and 7 wetlands (ibid., p. 42). The vegetation of a Type 3 wetland includes bulrushes, spike rushes and various other marsh plants such as cattails and smartweeds. Type 6 wetlands, colonized by willows, buttonbush and dogwood, normally occur along sluggish streams rather than in the coastal zone. The diverse habitats are probably related to the movement of raccoons to different environments throughout the year. 
The raccoon density per acre of wetland has not been well researched and hence is poorly known. Leo Posphical (personal communication) reports that 30 racoons evacuated a 200-acre site which was burned in the St. Clair Flats. Urban (1968, p. 60) determined a density of 45.3 racconns per square mile at the Winous Point Shooting Club, Ohio, which is a diked marsh with water level controls. Stuever (1941, p. 163) has suggested a mean density of 50 raccoons/square mile. Therefore the average density, based upon these reports, is 0.11 raccoons per acre.

The coastal wetlands acreage in Michigan totals 105,855 acres. If there are 0.11 raccoons per acre, the harvested population in the coastal wetlands is 11,647 raccoons. Based on the 28th Biennial Report of the DNR for 1975-1976, the average price per pelt is $\$ 28.00$. However, if a cost-of-living factor (1.129) is multiplied by the 1975-1976 price, the current value per pelt is $\$ 31.50$. The total estimated fur harvest of raccoons in the coastal wetlands is the value per pelt ( $\$ 31.50)$ multiplied by the annual harvest $(11,647)$. This value totals $\$ 366,880.50$ or $\$ 3.47$ per coastal wetland acre.

The carcass value of raccoons was $\$ 7.00$ per animal in 1975 (7 1bs./animal x $\$ 1.00 / 1 b$; unpublished report, Michigan DNR). If the price is updated to 1977, using the cost-of-living factor of 1.129 , then the current value is $\$ 7.90$ per animal $(1.129 \times \$ 7.00)$. Therefore, the estimated carcass value of raccoons harvested in coastal wetlands is $\$ 92,011(11,647 \times$ x $\$ 7.90)$ or $\$ 0.87$ per acre of coastal wetland. Given a raccoon harvest of 0.11 animals/ acre and a cumbined pelt and carcass value of $\$ 39.40 /$ animal ( $\$ 31.50 /$ pelt $+\$ 7.90$ carcass value), raccoons yield an average annual dollar value of $\$ 4.34$ per wetland acre. Assuming 105,855 acres of coastal wetland, a total return to the state of $\$ 459,411$ is estimated. 


\section{CONCLUSION}

Pelt and carcass values of furbearing wildife with regard to coastal wetlands is significant. The pelt and carcass value of muskrats with regard to coastal wetlands total $\$ 2,762,816$, or $\$ 26.10$ per wetland acre. If only cattail wetlands are considered, muskrats generate a total average return of $\$ 916,568$ or $\$ 29.75 /$ cattail acre. The value of raccoons is $\$ 459,411$, or $\$ 4.34$ per acre of coastal wetland. Therefore, the total value of muskrats and raccoons is approximately $\$ 3,222,227$, or $\$ 30.44$ per wetland acre per year.

The 3.2 million dollar value is based on just two furbearers. Other animals taken from wetlands include mink, deer and rabbits. The total mink harvest in Michigan in 1970-1971 was 10,050 animals and the fur price of mink in 1971 was $\$ 10.00$ per pelt (unpublished report, Michigan DNR). The total pelt value therefore, is approximately $\$ 100,000$ annually for the entire state. What portion is derived from coastal wetlands compared to other areas of the state is not known. However, what is significant is that the muskrat and raccoon values discussed above represent a minimum fur and carcass value. If, for example, a red fox, which has an approximate fur value of $\$ 65.00$, is trapped in a coastal wetland, the furbearer value would, of course, be considerably higher than $\$ 30.44 /$ wetland acre/year.

Although the dollar value of raccoons is not as high as muskrats, the wetland is important to the ecology of this animal. As noted, the raccoon may occupy a range of different habitats. Although wooded swamps (Type 7 wetland) are a favored habitat for dens, in autumn raccoons may predate on muskrats which favor deeper water marshes (Type 4 and Type 5 wetland). Also, a favorite and common food is crayfish which inhabitats waterlogged soils. The value of this furbearer may be low with regard to coastal wetlands but this habitat does support the life cycle of 
the species. Also, considering the value of raccoons to the state as a whole in 1970 was 10 million dollars, or over one-third of the total value of all wildlife harvested in Michigan (ibid.), preservation of its habitats warrant consideration. 


\section{CHAPTER FIVE \\ COMMERCIAL AND SPORT FISHING VALUES OF THE COASTAL WETLANDS}

This chapter examines the value of the coastal wetlands of Michigan with regard to fish spawning, commercial fishing, and sport fishing. It will be demonstrated that many of the coastal fishes which support the commercial and sport fisheries are warmwater species that are dependent on wetland habitats for spawning, feeding and other functions. Also, the economic value of sport angling in coastal wetlands will be shown to greatly exceed the commercial fishing value. SPAWNING OF FISH IN THE COASTAL WETLANDS

Through a survey of the literature, fish species spawning in the coastal wetlands of Michigan have been identified (Table 38). In some instances, e. g., the spawning of the Great Lakes muskellunge in the coastal marshes of western Lake Erie, destruction of the wetlands has since eliminated the spawning habitat (Trautman, 1957, p. 18 and 20). Little coastal spawning data were available for the coast of the Upper Peninsula and for the western coast of the Lower Peninsula of Michigan. One of the most intensive surveys of fish conducted in the coastal environments was that of Beak Consultants Inc. (1976) in Saginaw Bay.

Fish entrainment studies of cooling water intakes have enabled the Fisheries Division, Michigan DNR, to determine the fingerling production per wetland acre for walleye, northern pike, and several other fish species (personal communication, John Shauver). Based on data from 22 marshes, both inland and coastal, including lower 
TABLE 38

FISH SPECIES SPAWNING IN COASTAL WETLANDS OF MICHIGAN

\begin{tabular}{|c|c|c|}
\hline \multicolumn{3}{|c|}{ Lake Superior } \\
\hline Coastal Wetland Area & Species Spawning & Literature Source \\
\hline Apostle Islands & $\begin{array}{l}\text { Lake trout, lake white- } \\
\text { fish }\end{array}$ & $\begin{array}{l}\text { Lawrie \& Rahrer, } \\
1973, \text { p. 39, 44. }\end{array}$ \\
\hline Nipigon Estuary (Canada) & Walleye & $\begin{array}{l}\text { Lawrie \& Rahrer, } \\
\text { 1973, p. } 54 .\end{array}$ \\
\hline St. Marys River & $\begin{array}{l}\text { Northern pike, yellow } \\
\text { perch }\end{array}$ & $\begin{array}{l}\text { Intern'1 Lake } \\
\text { Superior Bd. of } \\
\text { Control, 1974, } \\
\text { p. 2-18. }\end{array}$ \\
\hline \multicolumn{3}{|c|}{ Lake Huron } \\
\hline Coastal Wetland Area & Species Spawning & Literature Source \\
\hline$\overline{\text { Potagannissing Bay }}$ & Northern pike, walleye & $\begin{array}{l}\text { Wright \& Schorf- } \\
\text { haar, 1976, p. } 4 .\end{array}$ \\
\hline Saginaw Bay & Perch, northern pike & $\begin{array}{l}\text { Consumers Power } \\
\text { Co., 1974, Vol. 2, } \\
\text { p. 2-7-49\&51. }\end{array}$ \\
\hline $\begin{array}{l}\text { Saginaw Bay, Fish Pt. } \\
\text { to Sand Point }\end{array}$ & Yellow perch & $\begin{array}{l}\text { Greg 01son (Pers. } \\
\text { commun.). }\end{array}$ \\
\hline $\begin{array}{l}\text { Saginaw Bay shoreline, } \\
\text { E. of Saginaw River }\end{array}$ & $\begin{array}{l}\text { Yellow perch, spottail } \\
\text { shiner, carp. alewife, } \\
\text { gizzard shad, N. pike. }\end{array}$ & $\begin{array}{l}\text { Beak Consultants, } \\
\text { Inc. } 1976, \text { p. 10, } \\
32,33,34,37, \& \\
41 .\end{array}$ \\
\hline $\begin{array}{l}\text { St. Joseph Channel } \\
\text { (Ontario) }\end{array}$ & Lake Trout & $\begin{array}{l}\text { Berst \& Spangler, } \\
\text { 1973, p. 15. }\end{array}$ \\
\hline \multicolumn{3}{|c|}{ Lake Erie } \\
\hline Coastal Wetland Area & Species Spawning & Literature Source \\
\hline Coastal marshes, N. Ohio & $\begin{array}{l}\text { N. pike, Great Lakes } \\
\text { muskellunge }\end{array}$ & $\begin{array}{l}\text { Trautman, } 1957, \mathrm{p} . \\
214 \& 217 .\end{array}$ \\
\hline $\begin{array}{l}\text { Kellys Island-Bass Is., } \\
\text { Lake Erie }\end{array}$ & Walleye & $\begin{array}{l}\text { Reiger et al., } \\
1969 \text {, p. } 50 .\end{array}$ \\
\hline Lake Erie Wetlands & $\begin{array}{l}\text { Perch, white bass, } \\
\text { gizzard shad, alewife } \\
\text { \& yellow pickerel }\end{array}$ & $\begin{array}{l}\text { Kreisman, McDonald, } \\
\text { Rosenbaum \& Snyder, } \\
1976, \text { p. } 19 .\end{array}$ \\
\hline $\begin{array}{l}\text { Raisin River mouth, } \\
\text { Monroe County }\end{array}$ & Carp & $\begin{array}{l}\text { Parkhurst, } 1971 \text {, } \\
\text { p. } 63 .\end{array}$ \\
\hline $\begin{array}{l}\text { Shoreline, W. Lake } \\
\text { Erie }\end{array}$ & Walleye & $\begin{array}{l}\text { Reiger et al. } \\
1969, \text { p. } 18 .\end{array}$ \\
\hline
\end{tabular}


TABLE 38 (Continued)

Lake Michigan

\begin{tabular}{|c|c|c|}
\hline Coastal Wetland Area & Species Spawning & Literature Source \\
\hline$\overline{\text { Grand Traverse Bay }}$ & $\begin{array}{l}\text { Bowfin, carp, golden } \\
\text { shiner, blacknose minnow, } \\
\text { N. pike, banded killi- } \\
\text { fish, yellow perch. }\end{array}$ & $\begin{array}{l}\text { Price and Kelley, } \\
1976, \text { p. 12, 28, } \\
30,31,37,41, \& \\
47 .\end{array}$ \\
\hline Green Bay marshes & Northern pike & $\begin{array}{l}\text { GLBC, App. } 8 \\
1975, \text { p. } 97\end{array}$ \\
\hline $\begin{array}{l}\text { Lake Michigan drowned } \\
\text { river mouths }\end{array}$ & $\begin{array}{l}\text { N. pike, panfish, bass, } \\
\text { Largemouth bass, carp, } \\
\text { goldfish. }\end{array}$ & $\begin{array}{l}\text { GLBC, App. } 8, \\
\text { Draft, no. 2, } \\
1972, \text { p. 223; } \\
\text { Richard Julian, } \\
\text { pers. commun. }\end{array}$ \\
\hline Little Bay de Noc & Perch & $\begin{array}{l}\text { Wagner, } 1972, \\
\text { p. } 56 .\end{array}$ \\
\hline $\begin{array}{l}\text { Little Bay de Noc, } \\
\text { mouth of Whitefish R. }\end{array}$ & Wa1leye & $\begin{array}{l}\text { Crowe, } 1962, \\
\text { p. } 353 .\end{array}$ \\
\hline Little Bay de Noc & Spottail shiner & Basch, 1968, p. 3. \\
\hline $\begin{array}{l}\text { Lower Little Manistee } \\
\text { River }\end{array}$ & Northern pike & $\begin{array}{l}\text { Wickland \& Dean, } \\
1957, \text { p. } 10 .\end{array}$ \\
\hline Muskegon River mouth & Walleye & $\begin{array}{l}\text { We11s \& McLain, } \\
\text { 1973, p. } 41 .\end{array}$ \\
\hline $\begin{array}{l}\text { Whitefish River, of } \\
\text { Green Bay }\end{array}$ & Walleye & $\begin{array}{l}\text { We11s \& McLain, } \\
\text { 1973, p. } 41 .\end{array}$ \\
\hline & Lake St. Clair & \\
\hline Coastal Wetland Area & Species Spawning & Literature Source \\
\hline $\begin{array}{l}\text { Big \& Little Muscamoot } \\
\text { Bays }\end{array}$ & Smallmouth bass & $\overline{\text { Latta, } 1954, \text { p. } 1 .}$ \\
\hline Dickinson Island & $\begin{array}{l}\text { Northern pike and } \\
\text { muskellunge }\end{array}$ & $\begin{array}{l}\text { Mich. DNR, EIS, } \\
1975 \mathrm{a}, \mathrm{p} .11 .\end{array}$ \\
\hline Eastern Anchor Bay & Smallmouth bass & Latta, 1954, p. 1. \\
\hline $\begin{array}{l}\text { Lake St. Clair } \\
\text { wetlands }\end{array}$ & $\begin{array}{l}\text { N. pike, walleye, perch, } \\
\text { smallmouth bass, channel } \\
\text { catfish, muskellunge, } \\
\text { and lake sturgeon. }\end{array}$ & $\begin{array}{l}\text { Kreisman, McDonald, } \\
\text { Rosenbaum \& Snyder, } \\
\text { 1976, p. } 18 .\end{array}$ \\
\hline Mitchell Bay & Smallmouth bass & Doan, 1940, p. 259. \\
\hline
\end{tabular}


TABLE 38 (Continued)

Lake St. Clair (Continued)

\begin{tabular}{|c|c|c|}
\hline Coastal Wetland Area & Species Spawning & Literature Source \\
\hline St. Clair Flats & N. pike, bluegill, carp. & $\begin{array}{l}\text { Greg Olson (pers. } \\
\text { communication). }\end{array}$ \\
\hline $\begin{array}{l}\text { St. Clair Flats, sedge } \\
\text { meadows }\end{array}$ & Northern pike & $\begin{array}{l}\text { Leo Posphical } \\
\text { (pers. commun.). }\end{array}$ \\
\hline St. Clair Flats & Smallmouth bass & $\begin{array}{l}\text { Latta, } 1957 \text {, } \\
\text { p. 23. }\end{array}$ \\
\hline $\begin{array}{l}\text { St. Clair Flats, deep } \\
\text { cattail marsh }\end{array}$ & $\begin{array}{l}\text { Sma1lmouth bass, large- } \\
\text { mouth bass, carp, blue- } \\
\text { gill. }\end{array}$ & $\begin{array}{l}\text { Leo Pospichal } \\
\text { (pers. commun.) }\end{array}$ \\
\hline St. Johns Marsh & $\begin{array}{l}\text { N. pike, muskellunge, } \\
\text { smallmouth bass, large- } \\
\text { mouth bass, walleye, } \\
\text { yellow perch, and } \\
\text { bluegill. }\end{array}$ & $\begin{array}{l}\text { Michigan DNR, } \\
\text { 1976a, Proposed } \\
\text { St. Johns Rec. } \\
\text { Area, p. } 4 .\end{array}$ \\
\hline
\end{tabular}

Harsens Island, fingerling production of walleye and northern pike in 1976 were estimated to be 1,220 and 374 fingerlings/wetland acre/year, respectively (Current FilesFingerling Production Data, Fisheries Div., Michigan DNR). Using the Thompson-Bell method of projecting the annual recruitment of fingerling fish to various year classes (Ricker, 1975, p. 237), it is possible to estimate the annual wetland acre production of adult fish. By employing the fingerling data and the penalty system (whereby the Michigan DNR may impose a fine of $\$ 10$ per pound of game fish illegally taken or lost to the fishery), northern pike production in lower Harsens Island may be valued at $\$ 170 /$ wetland acre/year.

A diversity of warmwater, non-salmonid species of fish spawn in the coastal wetlands of the Great Lakes. The northern pike (Esox lucius) is one of the wetlanddependent species which spawns in the wetlands, usually distributing its eggs in shallow sedge marshes or in flooded fields (Trautman, 1957, p. 214; Williams and Jacob, 1971, p. 3). Carp (Cyprinus carpio) commonly 
broadcast their eggs over vegetation or debris in warm, shallow coastal bays and marshes (Trautman, 1957, p. 285; Lake Erie Research Unit Staff, 1976). The yellow perch (Perca flavescens) can also be categorized as a wetland spawner because the species strews its eggs over aquatic vegetation or submerged brush of inshore waters (Lake Erie Research Unit Staff, 1976). Nesting of smallmouth bass (Micropterus dolomieui) has been observed among bulrush clumps on the sandy, nearshore flats along the margin of the St. Clair River delta (Doan, 1940, p. 259; Latta, 1954, p. 1).

Man's impact on the coastal environment has severely degraded and/or eliminated the spawning and nursery habitats in many wetlands. The clearing and draining of the Black Swamp of northwest Ohio and adjacent Michigan, the Saginaw Bay lowlands, and the lower Green Bay marshlands for agriculture may be the primary cause of the collapse of the commercial fisheries in these areas. Agricultural crops now flourish where northern pike, Great Lakes muskellunge and lake sturgeon once spawned in coastal Ohio (Trautman, 1957, p. 20). Until 1890 when industrial expansion began to occur, lake whitefish commonly spawned in Maumee Bay and the Detroit River (Hartman, 1973, p. 26). Turbid waters and silt-covered bottoms hinder sight-feeding gamefish, but favor bottom feeders such as carp, redhorse, and white suckers. (Shepherd, 1973, p. 23).

In addition to agricultural development, extensive urbanization and industrialization of the lower Fox River Valley has resulted in the deterioration of the aquatic environment of the lower Green Bay (Great Lakes Basin Comm., 1975a, p. 97). Populations of tolerant species such as carp and suckers have subsequently increased, while common whitefish, walleye, northern pike and yellow perch have declined. Draining of the coastal wetlands eliminated the spawning habitat of the northern pike. 
The paper industries have caused thermal pollution, wood fiber deposition, and chemical deterioration which, in turn, has eliminated both warm- and coldwater fisheries in the lower tributaries and nearshore environments of the Green Bay (ibid., p. 97).

Along the coast of Saginaw Bay a fine, black anaerobic layer of ooze has recently been observed (ibid., p. 141). Other water quality problems along the shoreline of the inner bay include increases in dissolved solids, chlorides and sulfates and a decrease in oxygen levels especially during calm summer days. Dredge and fill operations have also eliminated fish habitat. Currently, the main commercial fish species in Saginaw Bay, in decreasing order of importance by value, are: channel catfish, yellow perch, carp, black crappie, bullheads and quillback (U. S. Dept. of Interior, 1976). Northern pike and walleye were removed from the list of commercial species in 1966 and 1970, respectively. Through habitat degradation and restriction on the taking of certain species, e.g., northern pike, only medium- to low-valued, warmwater species remain for the commercial fishermen to pursue.

Under natural conditions, the coastal wetlands are capable of supporting a diverse and balanced fish community. The species common to the wetlands of Michigan have been listed in Table 39. Note the diversity, including predator fish such as northern pike and smallmouth bass as well as forage minnows such as the blacknose shiner and golden shiner. When siltation and chemical pollution occur, large predators and forage minnows disappear and fast-growing detritivores increase (Table 40). This species succession toward more tolerant species is in an advanced stage in the coastal wetlands of western Lake Erie. Habitat changes in coastal Lake Erie favor low-value species such as freshwater drum, 
COMMON FISH SPECIES UTILIZING THE COASTAL WETLANDS OF MICHIGAN

Common Name
Northern longnose gar
Bowfin
Northern pike
Great Lakes muskellunge
Walleye
Yellow Perch
Largemouth bass
Smallmouth bass
Bluegill
Pumpkinseed
Green sunfish
Black crappie
Western banded killifish
Carp
Goldfish
Pugnose minnow
Blackchin shiner
Blacknose shiner
Spottail shiner
Emerald shiner
Golden shiner
Pirate perch
Channel catfish
Black bullhead
Brown bullhead
Yellow bullhead
Freshwater drum
Redhorse
White sucker
Gizzard shad
Johny darter
Trout-perch
Scientific Name Lepisosteus osseus oxyurus
Amia calva
Esox lucius
Esox masquinongy
Stizostedium vitreum
Perca flavescens
Micropterus salmoides
Micropterus dolomieui
Lepomis macrochirus
Lepomis gibbosus
Lepomis cyanellus
Pomoxis nigromaculatus
Fundulus diaphanus menona
Cyprinus carpio
Carassius auratus
Opsopoeodus emiliae
Notropis heterodon
Notropis heterolepis
Notropis hudsonius
Notropis antherinoides
Notemigonus crysoleucas
Aphredoderus sayanus
Ictalurus punctatus
Ictalurus melas
Ictalurus nebulosus
Ictalurus natalis
Aplodinotus grunniens
Moxostoma spp.
Catostomus commersoni
Dorosoma cepedianum
Etheostoma nigrum
Percopsis omiscomaycus

Source: Compiled from Trautman, 1957; Hubbs and Lagler, 1958; and Scott and Crossman, 1973.

alewife, gizzard shad, carp, and goldfish (Great Lakes

Basin Comm., 1975a, p. 163).

VALUE OF COASTAL WETLANDS TO COMMERCIAL FISHING

Commercial fishing in Michigan is not a large industry. In 1975 there were 161 licensed commercial fisherman who landed 11.51 million pounds of fish valued 
TABLE 40

FISH SPECIES INHABITING COASTAL WETLANDS WHICH

ARE TOLERANT TO TURBIDITY, SILTATION, AND POLLUTION

Species Tolerant to an Increase in Turbidity and

Siltation:

Gizzard shad

Big mouth buffalofish

Channel catfish

Brown bullhead

Black bullhead
White crappie

Black crappie

Green sunfish

Sauger

Freshwater drum

(Sheepshead)

Species Tolerant to Organic and Inorganic Pollution:

Common white sucker

Carp

Goldfish

Source: Pinsak and Meyer, 1976, p. 154.

at approximately $\$ 3.0$ million (Scott, 1977, p. 4). By weight, Lake Michigan alone accounted for 64 percent of the total state harvest, with its alewife landings contributing 32 percent of the entire statewide catch. With regard to the value of fish landings, in 1976 the most important commercial species, in descending order by value of total harvest, were common whitefish, chubs, channel catfish, yellow perch, carp, smelt, lake trout, alewives, black crappie, Menominee whitefish, and all others (Table 41).

Little commercial fishing occurs within coastal wetlands per se, except for the harvesting of carp and other medium- to low-value, warmwater species. The coastal wetlands are too shallow and the bottoms either too unconsolidated or strewn with obstacles to permit efficient fishing with trawls or gill nets. Haul seines 


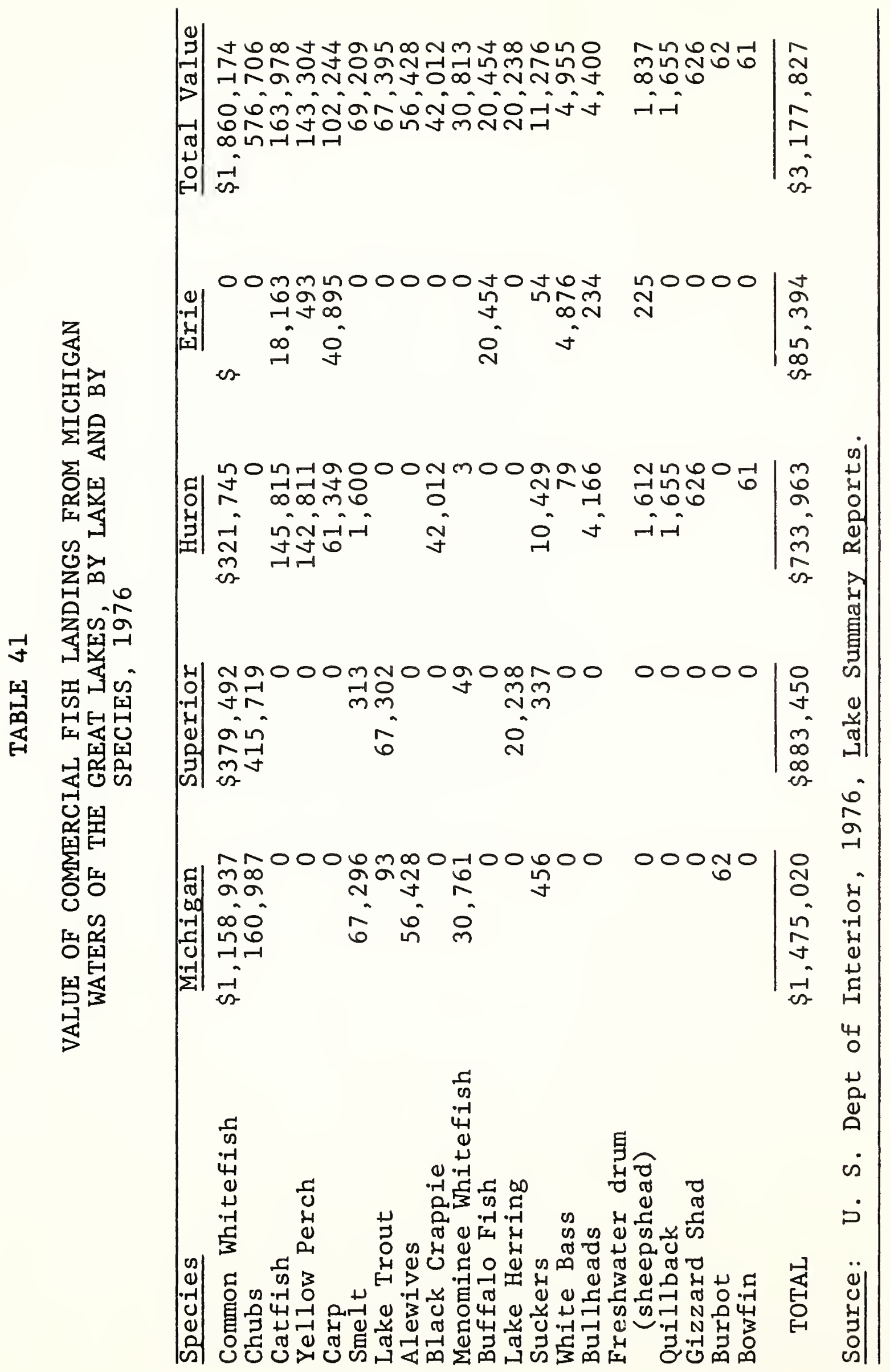


are utilized in the shallow bays of western Lake Erie to catch carp, goldfish, and freshwater drum (Reiger and Hartman, 1973, p. 1249). Seines are a common gear type in waters with depths of 7 to 12 feet, whereas trap nets are usually set in slightly deeper water so as to allow pleasure craft to pass over without snagging the gear (Howard, 1972, p. 35).

With the possible exception of suckers, there appears to be less commercial fishing activity in the coastal wetlands of either Lake Superior or Lake Michigan. Much of this lack of activity can be explained by the closing of bays, such as Bay de Noc to commercial fishing. Yellow perch are not abundant in Lake Superior, and in Lake Michigan the perch fishery has been closed to commercial fishermen since 1970. Some fishing of yellow perch does occur in the Wisconsin waters of lower Green Bay, and in the Indiana waters of Lake Michigan (personal communication, Ned Fogle). Other warmwater species, such as carp and channel catfish, do not sustain a commercial fishery in Lake Michigan or Lake Superior.

Commercial fishing in Potagannissing Bay (St. Marys River) of Lake Huron has been an important industry since the late 1800's. During the 1930's, for example, the commercial harvest in Potagannissing Bay consisted primarily of suckers, along with walleye, muskellunge and yellow perch (Westerman and van Oosten, 1937, p. 27). In 1966, the northern pike was closed to commercial fishing in Lake Huron waters as was the walleye in 1970. By removing these species from the commercial list, sport fishing now dominates in the St. Marys River-Drummond Island-Les Cheneaux Island area. Nevertheless, suckers are still an important commercial species, although most of the catch is taken in rivers during spring spawning runs. Carp are becoming more abundant near the Potagannissing River in Potagannissing Bay, but the low-value 
species does not suppport a permanent commercial fishery at this location.

Saginaw Bay supports the largest commercial fishery which extends into the coastal wetland environments of Michigan. In 1975, 28 commercial fishermen, principally from the Bayport-Sebewaing-Linwood area, landed 1,323,847 pounds, valued at $\$ 313,190$ (Table 42). Most of the yellow perch, carp, and sucker harvest, as well as a large portion

TABLE 42

COMMERCIAL FISH LANDINGS IN SAGINAW BAY (LAKE HURON) BY SPECIES, 1975

\begin{tabular}{lrr}
\hline Species & Pounds Landed & \multicolumn{1}{c}{ Value } \\
\cline { 2 - 3 } Carp & 626,398 & $\$ 47,174$ \\
Channel catfish & 282,148 & 109,198 \\
Yellow perch & 257,203 & 91,927 \\
Black crappie & 85,451 & 56,354 \\
Bullheads & 37,354 & 4,229 \\
Quillback & 16,468 & 2,525 \\
Freshwater drum & 15,937 & 1,698 \\
Bowfin & 2,331 & 58 \\
Gizzard shad & 440 & 23 \\
White bass & 117 & 4 \\
\multicolumn{1}{c}{ TOTAL } & $1,323,847$ & $\$ 313,190$
\end{tabular}

Source: Current Files, Fisheries Div., Michigan DNR. *A small percentage of this catch may also derive from Tawas and Thunder Bays.

of the channel catfish landings from Lake Huron derive from Saginaw Bay (Parsons, 1974, p. 34). Channel catfish, yellow perch, black crappie, carp, and bullheads, in that order by value, clearly dominate the cotal landings. Although the black crappie is a commercial species in 
Saginaw Bay, elsewhere in Michigan it is designated as a sport fish.

Commercial fishing on the United States side of Lake St. Clair and the St. Clair River has been closed since the 1930's, except for the temporary fishing of catfish during the $1960^{\prime} \mathrm{s}$. At present there may be an underutilized stock of channel catfish offshore from the Clinton River cutoff (personal communication, Bob Haas). The only commercial fishery in Lake St. Clair is operated by the Walpole Indians of Ontario who harvest northern pike from the wetlands of Walpole Island. Commercial fishing in the Detroit River has also been discontinued for several decades.

With regard to the Michigan shoreline of western Lake Erie, only the shallow bays, such as La Plaisance Bay, support any commercial fishing activity. In 1975 , five commercial fishermen, most of whom ported out of Monroe, Michigan, harvested 483,879 pounds of fish, valued at $\$ 41,560$ (Table 43). Of these five fishermen, three seine for carp in waters that may be as shallow as 4 to 6 feet deep (personal communication, Ned Fogle). Some fishing by Ohio commercial fishermen occurs in Maumee Bay. In 1974, the principal catch in Maumee Bay was carp, with smaller quantities of white bass, channel catfish, yellow perch, bullheads, and freshwater drum (Pinsak and Meyer, 1976, p. 165).

Several commercial fishermen along western Lake Erie place carp caught from the lake shore into holding ponds or barges before marketing. The carp are usually held six weeks awaiting holiday market days, during which time the fish are fattened or "cured" on shelled corn (Howard, 1972, p. 86). In contrast to Michigan's carp ponds which function as holding or fattening pens, in Asia and the Near East, carp ponds are used for rearing from eggs or small fry. In Israel and Germany, carp 
ponds produce an average of 386 pounds of carp per acre/ year (Pirie, 1973, p. 324). At 8 cents per pound (current price of carp in Michigan), this amounts to $\$ 30.85$ per acre/year.

In summary, the economic value of commercial fishing in the coastal wetlands of the state of Michigan is small. In 1975, the commercial harvest in coastal wetlands amounted to $1,807,726$ pounds, which was valued

TABLE 43

COMMERCIAL FISH LANDINGS FROM MICHIGAN'S COASTAL WATERS OF LAKE ERIE, BY SPECIES, 1975

\begin{tabular}{|c|c|c|}
\hline Species & Pounds Landed & Value \\
\hline Carp & 422,204 & $\$ 21,749$ \\
\hline Buffalo fish & 33,965 & 10,078 \\
\hline Channel catfish & 13,950 & 6,453 \\
\hline White bass & 4,558 & 1,511 \\
\hline Bullheads & 3,221 & 624 \\
\hline Freshwater drum & 2,218 & 148 \\
\hline Suckers (incl. redhorse) & 1,964 & 49 \\
\hline Yellow perch & 1,799 & 948 \\
\hline TOTAL & 483,879 & $\$ 41,560$ \\
\hline Current Files, & Fisheries Div. & Michigan DNR. \\
\hline
\end{tabular}

at $\$ 354,750$. Using a cost-of-living factor of 1.129 to convert the 1975 value to a 1977 value, the total commercial fish harvest from the coastal waters in 1977 is worth $\$ 400,513$, or an average of $22 \$ /$ pound. For the 33 fishermen involved in the fishing of coastal areas, the average annual income per fisherman would be $\$ 12,135$. This wetland catch is approximately 12 percent of the total weight of the statewide commercial harvest, and approximately 15 percent of the total value. Given 105,855 acres of coastal wetland in Michigan, commercial fishing therein yields 17.1 pounds per acre/year, for a value of $\$ 3.78$ per 
acre/year. However, if carp are raised in wetland ponds, the value may be $\$ 30.85$ per acre/year. If all of Michigan's Great Lakes commercial fish catch (see Table 41) is considered to be wetland dependent, then the commercial fish value would average approximately $\$ 30 /$ wetland acre/year $(\$ 3,177,827$ divided by 105,855 acres $)$.

Commercial fishing in the Great Lakes coastal wetlands has deteriorated from its former status due to environmental degradation, species succession, overfishing, and restrictions on the catching of several high value species. Nevertheless, there are underutilized fish stocks including freshwater drum, white bass, bullheads, channel catfish, suckers, and carp (Cable, 1971, p. 357). Many wetlands have populations of fast-growing forage fish such as carp and gizzard shad, which presently have little commercial value (Messman et al., 1977, p. 89; Greenwood, 1971, p. 415).

VALUE OF COASTAL WETLANDS TO SPORT FISHING

The economic value of sport fishing may be calculated by several methods. A common technique, and the one employed herein, is to utilize the 1970 freshwater fisherman's average annual expenditures of $\$ 127$ or the $\$ 6.30$ value of an angler day (U. S. Dept of Interior, 1972, p. 9). Using cost-of-living factors, these 1970 values can be extrapolated to the year 1977. In contrast, Stroud (1977, p. 2), based on the amount of money a fisherman would require in compensation to forfeit a day of fishing, suggests that the value of an angler day of inland, warmwater fishing is worth $\$ 49.66$. Another method would involve fixing a dollar value on each fish in the fishery. At present the Fisheries Division of Michigan's DNR may impose a fine of $\$ 5$ to $\$ 10$ per pound of game sport fish illegally taken or lost to the fishery (personal communication, Bill McClay). However, in order to be consistent with the estimated values of waterfowl hunting, the first technique described above will be utilized in this report. Specifically, angler day values will be employed as opposed to average annual expenditures because data on the number of fishermen may not be available. 
In 1975 approximately 1.16 million sportsmen fished in Michigan's waters and expended a total of 20 million angler days (Jamsen, 1976, p. 2). Based on the 1970 National Survey of Fishing and Hunting (U. S. Dept. of Interior, 1972, p. 9), as extrapolated to the year 1977 by employing a 1.542 cost-of-living factor for Michigan (personal communication, Bob Craig), each freshwater fisherman in 1977 spent $\$ 196$, or $\$ 9.72$ per angler day. Given an estimated 1,164,160 Michigan sport fishermen and an average annual expenditure of $\$ 196$, the total economic value of sport fishing in Michigan is $\$ 228 \mathrm{mil-}$ lion. Using an angler day value of $\$ 9.72$ and 20 million angler days, the total economic value is estimated to be $\$ 194.4$ million. A study in press regarding the economics of Great Lakes sport fishing indicates that in 1977 the value of an angler day ranged between $\$ 7$ and $\$ 10$ and that the total value of Michigan's sport fishery is $\$ 250$ million (Talhelm, in press, p. 8). Thus, a total economic value of $\$ 200$ million for Michigan's sport fishery appears corroborated.

Data on the number of sport fishermen and fishing effort in Michigan are presented in Table 44. Information specific to the coastal wetlands is not available. Warmwater sport fishing in the coastal wetlands, and in other shore environments, is contained within the Great Lakes non-salmonid fishing category. In comparison, fishing of inland lakes and streams, which focuses on nonsalmonid fish, e.g., panfish, yellow perch, and bass, clearly dominates the state's sport fishing activity (Jamsen, 1973, p. 28). Great Lakes fishing of nonsalmonids involved an estimated 413,100 participants, for a total of 4,361,180 angler days. Yellow perch was the most sought after species (Jamsen, 1976, p. 2). Assuming a current fishing effort of 4,361,180 angler days per year and using the $\$ 9.72$ figure per angler day, the Great 
TABLE 44

NUMBER OF SPORT FISHERMEN AND FISHING EFFORT BY TYPE OF SPORT FISHING, IN MICHIGAN, 1975

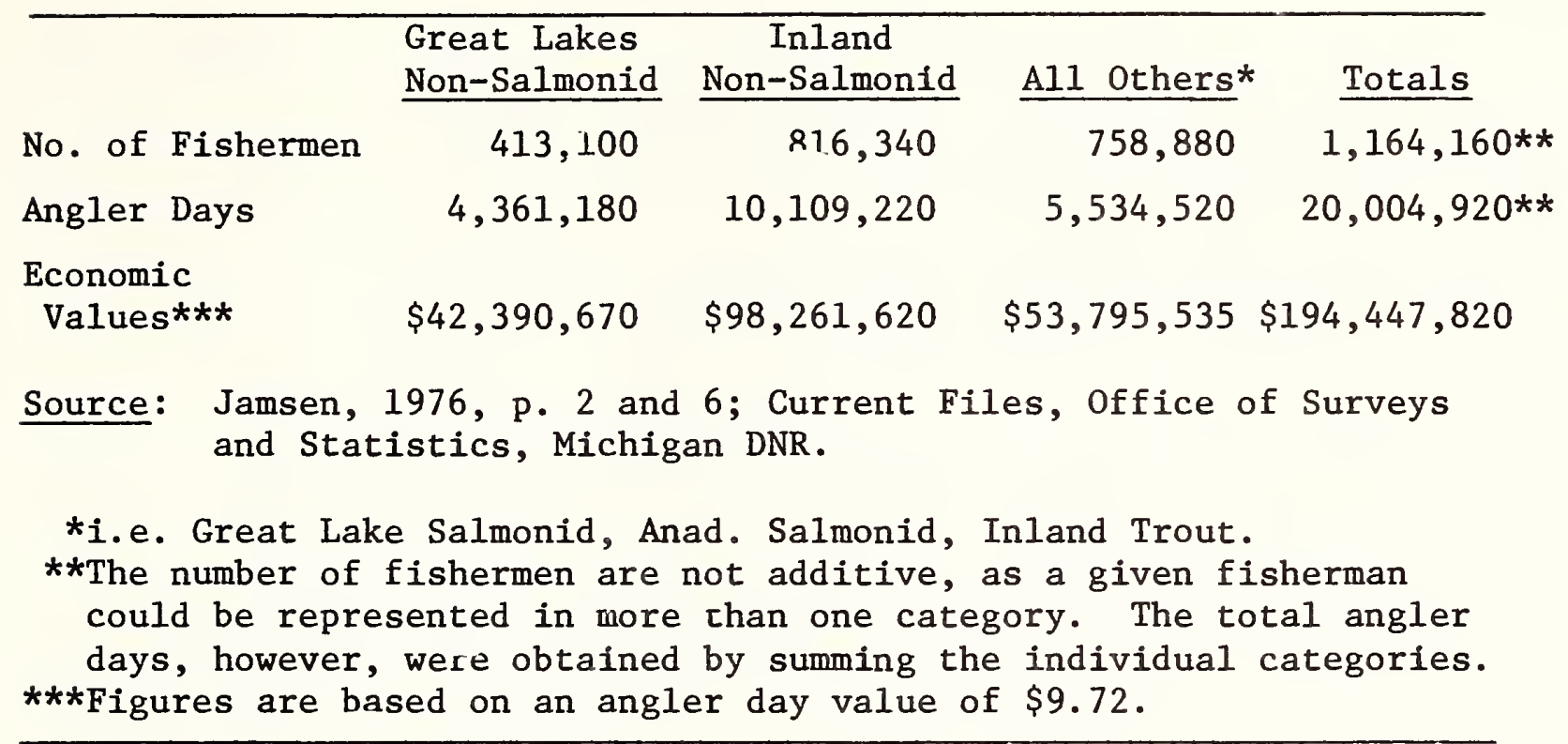

Lakes non-salmonid sport fishery for 1977 is estimated to be worth $\$ 424$ million to the state of Michigan.

Because yellow perch accounts for 71 percent of the Great Lakes non-salmonid hook and line catch (Jamsen, 1976 , p. 2), it is instructive to examine the geographic distribution of this fishery. The southern Lower Peninsula is the source of 83 percent of the state's Great Lakes yellow perch fishing demand (Table 45). This large percentage appears reasonable considering that 81 percent of the state's licensed sport fishermen reside in southern Michigan (Jamsen, 1973, p. 23). Wayne County alone generates nearly 20 percent of the total Great Lakes yellow perch sport fishery demand (see Table 45). Hence, that much of the non-salmonid fishing demand derives from the urban centers in southeastern Michigan is beyond question.

It is felt that much of the Great Lakes sport fishing effort is expended in open-water areas as compared to the coastal wetlands. Nonetheless, because some of the species being fished either spawn or feed in wetland 
TABLE 45

NUMBER AND RESIDENCE OF GREAT LAKES YELLOW PERCH FISHERMEN BY REGION, IN MICHIGAN, 1975

\begin{tabular}{|c|c|c|c|c|}
\hline$\underline{\text { Region }}$ & Fishermen & Percent & $\begin{array}{l}\text { Number } 0 \\
\text { Fishermer } \\
4 \text { Leading } \\
\end{array}$ & $\begin{array}{l}\text { Perch } \\
\text { in the } \\
\text { Counties }\end{array}$ \\
\hline Upper Peninsula & 10,200 & 4 & Wayne & 55,600 \\
\hline N. Lower Peninsula & 35,800 & 13 & Macomb & 30,200 \\
\hline S. Lower Peninsula & 218,800 & 83 & Oakland & 19,200 \\
\hline TOTAL & 264,800 & $100.0 \%$ & Saginaw & 18,600 \\
\hline $\begin{array}{l}\text { Current } \\
\text { Michigan }\end{array}$ & s, Office & OL surv & and stat & tics, \\
\hline
\end{tabular}

environments, e.g., northern pike and yellow perch, a portion of the Great Lakes non-salmonid fishing activity can be considered part of the coastal wetland fishery.

Lake Superior has traditionally been renowned for its high quality sport fishery, especially in bay and shoal areas, including the Apostle Islands, Keweenaw Bay, and tributary streams (U. S. Dept. of Interior, 1970b, p. 2). A 1970 creel census in Michigan waters of the lake revealed that the following species, in ranked order by number caught, constituted the main sport fish: smelt, yellow perch, suckers, centrarchid panfish, northern pike, walleye, and bass (Great Lakes Basin Comm., 1975a, p. 58). With the exception of smelt, these species inhabit the warmwater, shore environments and tributary streams as well as many of the inland lakes (U. S. Dept. of Interior, 1970, p. 44).

Some information is available on the sport fishing of coastal wetlands in the Upper Peninsula along the northern shore of Lake Michigan. The 1971 creel census revealed that the principal non-salmonid sport fishes were yellow perch, smelt, suckers, smallmouth bass, northern pike, walleye, and centrarchid panfish (Great 
Lakes Basin Comm., 1975a, pp. 88-89). The catch on the lower Menominee River generally consists of northern pike, bullheads, walleye and other species (State of Michigan, 1967, p. 36). A creel census in 1965 in Little Bay de Noc indicated that the principal sport fishes, in order of catch, were yellow perch, brown bullhead, rock bass, pumpkinseed sunfish, northern pike, smallmouth bass, bluegill, walleye, and black crappie (Wagner, 1968, p. 3). Ice fishing generates somewhat more angling activity than open-water fishing in the Bay de Noc area.

In 1965, ice fishing at Little Bay de Noc generated 29,322 hours, while open-water anglers fished 16,785 hours, for a total of 46,107 angler hours (ibid., p. 1). For calculation of economic value, it is assumed that the current sport fishing demand is 50,000 angler hours and that an angler day is equivalent to six hours of fishing. The economic value of sport fishing in Little Bay de Noc, using $\$ 9.72$ as the value of an angler day, is $\$ 81,000$. Given 1,458 acres of coastal wetland in the bay (see Table 4), the value of sport fishing is $\$ 56$ per wetland acre/year.

With regard to Michigan sport fishery along the eastern shore of Lake Michigan, little information is available. In this area, much of the fishing effort was traditionally expended on the inland lakes and streams (Great Lakes Basin Comm., 1975a, p. 109). Nevertheless, important sport fish along the coast include the yellow perch, smelt, suckers, smallmouth bass, northern pike, walleye, and centrarchid panfish. Yellow perch fishing from piers and jetties open to the public is particularly intense in southern Lake Michigan (ibid., p. 90) and may be increasing as additional structures are built. With regard to the coastal wetlands, the drowned river mouths and the estuary-like lakes furnish habitat for northern pike, bass, and panfish not found elsewhere along the 
coast due to the absence of nearshore wetlands. Sport fishes of Grand Traverse Bay include yellow perch, largemouth bass, smallmouth bass, bluegill, rockbass, white sucker, and northern pike along with smelt and several anadromous species (Price and Kelly, 1976, p. 54).

The St. Marys River, which connects Lake Superior and Lake Huron, has long been a highly regarded sport fishing area. Recent studies indicate that the fishing potential for yellow perch, walleye and northern pike in Potagannissing Bay is excellent (Wright and Schorfhaar, 1976, pp. 2-4). The 01d Channel currently supports yellow perch, northern pike, walleye, and sucker populations (Parsons, 1974, p. 75). In Munuscong Bay and in areas north of Drummond Island, valuable aquatic vegetation grows in water depths up to 25 feet. At St. Marys Rapids, south of Lake Superior, over 100,000 angler days are expended annually on the United States' side. However, much of this activity is directed toward lake whitefish and rainbow trout (Intern'l Lake Superior Bd. of Control, 1974, pp. 2-19). Some pier fishing by local residents also takes place at the Rapids for yellow perch. Lake Huron and Lake St. Clair fishermen generate 75 percent of the Great Lakes non-salmonid fishing demand and account for 81 percent of the total yellow perch catch. Within the Great Lakes, Saginaw Bay and Lake St. Clair receive the heaviest hook and line pressure for yellow perch, panfish, walleye, bass, northern pike, and muskellunge (Jamsen, 1976, p. 2). With reference to Lake Huron, by far the majority of warmwater sport fishing effort takes place in Saginaw Bay, Les Cheneaux, and Drummond Island areas. The 1970 creel census revealed that the following ranked order of species by number caught comprised the important sport fishes of Lake Huron: yellow perch, centrarchid panfish, suckers, bass, northern 
pike and muskellunge (Great Lakes Basin Comm., 1975a, p. 137).

Saginaw Bay is a popular area for the sport fishing of yellow perch, walleye, and channel catfish (Parsons, 1974, p. 34). Sixty-one percent of the Lake Huron non-salmonid sport fishing activity in 1975 occurred in Saginaw Bay (Jamsen, 1976, p. 2). Fishing for yellow perch accounts for 54 percent of the fishing effort of Lake Huron, but much of this occurs in Saginaw Bay. In summer, perch fishing is particularly intense between Fish Point and Sand Point, and near Port Austin (personal communication, Greg 0lson). Ice fishing for yellow perch is also popular in winter at Fish Point (personal communication, Randy Eshenroder).

In 1975, an estimated 125,630 sport fishermen expended 863,600 angler days to catch 12.46 million fish in Saginaw Bay (Table 46). If we assume that the current annual warmwater sport fishing effort in Saginaw Bay, excluding smelt and salmonid fishing, is 787,000 angler days $^{1}$ and using the $\$ 9.72$ figure as a value of an angler day, then the warmwater, non-salmonid sport fishery of Saginaw Bay is valued at $\$ 7.66$ million. At present, Saginaw Bay has 17,816 acres of coastal wetland (see Table 4). On an area basis, the warmwater, non-salmonid sport fishery of Saginaw Bay is valued at $\$ 429$ per wetland acre/year.

Lake St. Clair is the most valuable Great Lakes area for non-salmonid sport fishing in Michigan. In 1975 , 33 percent of all Great Lakes fish catch and 48 percent of the fishing effort were expended on Lake St. Clair (Table 47). In spite of its relatively small area, more walleye, bass, and centrarchid panfish are taken from Lake St. Clair than from any other Michigan Great Lakes water body. Charter boat operators exploit the fact that one-half of the state's muskellunge catch comes from Lake St. Clair

\footnotetext{
${ }^{1}$ Personal communication, Gale Jamsen.
} 
TABLE 46

SPORT FISH CATCH AND FISHING EFFORT IN SAGINAW BAY BY SPECIES, 1975

\begin{tabular}{|c|c|c|c|c|c|}
\hline \multicolumn{2}{|l|}{ Species } & No. of Fis & Caught & $\%$ of & Total Catch \\
\hline \multicolumn{2}{|c|}{ Yellow perch } & 10,96 & 790 & & 88 \\
\hline \multicolumn{2}{|c|}{$\begin{array}{l}\text { Panfish and white } \\
\text { bass }\end{array}$} & 70 & 30 & & 6 \\
\hline \multicolumn{2}{|c|}{$\begin{array}{l}\text { Bullheads and } \\
\text { Catfish }\end{array}$} & $52 ?$ & +30 & & 4 \\
\hline \multicolumn{2}{|l|}{ Bass } & & 90 & & $<1$ \\
\hline \multicolumn{2}{|l|}{ Suckers } & & 30 & & $<1$ \\
\hline \multicolumn{2}{|c|}{ Northern pike } & & 10 & & $<1$ \\
\hline \multicolumn{2}{|c|}{ Salmon and Trout } & & 60 & & $<1$ \\
\hline \multicolumn{2}{|c|}{ Al1 others } & & 90 & & 1 \\
\hline \multirow[t]{2}{*}{ TOTAL } & & 12,460 & 30 & & $100 \%$ \\
\hline & $\begin{array}{l}\text { Number of } \\
\text { Angler Da }\end{array}$ & $\begin{array}{l}\text { Fishermen } \\
\text { ys }\end{array}$ & $\begin{array}{l}125,63 \\
863,60\end{array}$ & & \\
\hline Source: & $\begin{array}{l}\text { Current } \\
\text { Michigan }\end{array}$ & $\begin{array}{l}\text { Files, off } \\
\text { DNR. }\end{array}$ & of Sur & s and & Statistics, \\
\hline
\end{tabular}

(Schrouder, 1975, p. 4). Because of the lake's popularity and accessibility, many unlicensed fishermen from wayne, Oakland, Macomb, and St. Clair counties fish in Lake St. Clair (Great Lakes Basin Comm., 1975a, p. 187).

The St. Clair River delta consists of approximately 16,000 acres of coastal wetland, the lower part of which provides fishing opportunities for metropolitan Detroit and adjacent Ontario. As indicated in Figure 22, the shallow, marshy bays, river channels and weedy lakes provide high quality sport fishing of northern pike, smallmouth bass, perch, bluegill, and walleye. In St. Johns Marsh, the fishing of yellow perch, bluegills, largemouth bass, and northern pike is popular from shore sites as well as from small boats (Michigan DNR, 1976a, 


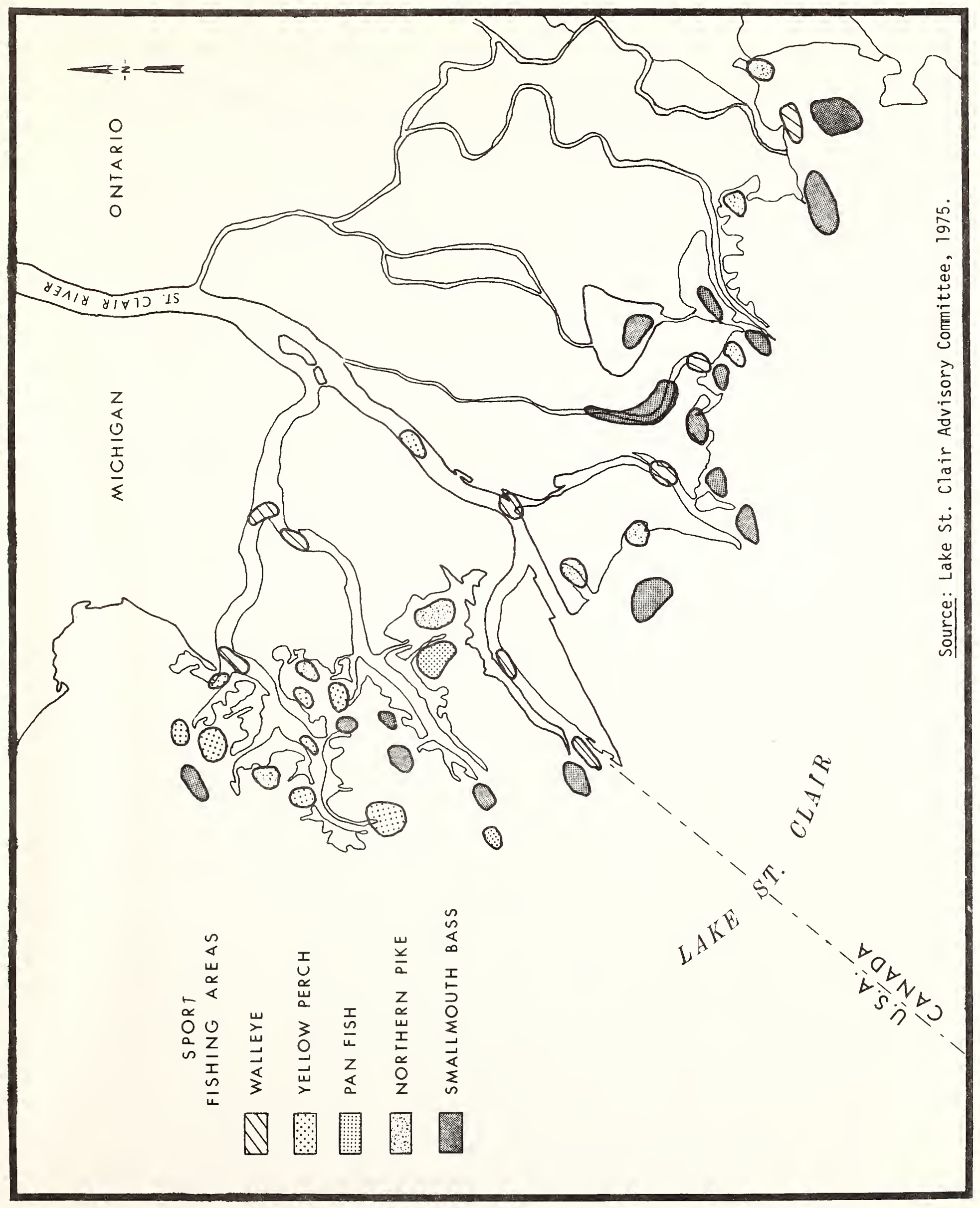

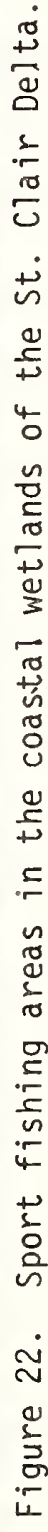


TABLE 47

MICHIGAN NON-SALMONID SPORT FISH CATCH AND FISHING EFFORT, LAKE ST. CLAIR VS. OTHER MICHIGAN GREAT LAKES WATERS, 1975

\begin{tabular}{|c|c|c|c|c|c|c|}
\hline & $\begin{array}{l}\text { Yellow } \\
\text { Perch }\end{array}$ & Walleye & Bass & Panfish & $\begin{array}{l}\text { Northern } \\
\text { Pike } \\
\end{array}$ & $\begin{array}{l}\text { \% of } \\
\text { total } \\
\end{array}$ \\
\hline St. Clair & $6,803,060$ & 809,030 & 399,500 & $1,490,900$ & 114,410 & 33 \\
\hline $\begin{array}{l}\text { Al1 } \\
\text { Others }\end{array}$ & $17,856,660$ & 96,560 & 329,630 & $1,294,040$ & 168,300 & 67 \\
\hline TOTAL & $24,659,720$ & 905,590 & 729,130 & $2,784,940$ & 282,710 & 100 \\
\hline
\end{tabular}

$\begin{array}{ccc} & \text { Angler Days } & \text { Percent of Total } \\ \text { St. Clair } & 1,996,990 & 48 \\ \text { A11 Others } & 2,137,750 & \frac{52}{-} \\ \text { TOTAL } & 4,134,740 & 100\end{array}$

Source: Jamsen, 1976, p. 6 .

p. 4). Ice fishing, particularly in eastern Anchor Bay, attracts many sportsmen from a wide area.

It has been estimated that lower Harsens Island, which is 2,600 acres in size, supports an estimated 100,000 angler days per year of sport fishing activity (Pospichal, undated, p. 8). At an angler day value of $\$ 9.72$, this amounts to a total of $\$ 972,000$ per year, for an area value of $\$ 374$ per wetland acre/year.

The United States portion of the St. Clair River delta consists of approximately 8,500 acres of wetlands. It has been determined that the value of sport fishing on Lake St. Clair totals $\$ 19,410,740$, which is obtained by multiplying $1,996,990$ angler days (see Table 47) by $\$ 9.72$ (the value of one angler day). Given 8,500 acres of wetland on the United States side of the delta, the value of sport fishing per wetland acre in Lake St. Clair equals $\$ 2,284$ per year. However, much of the actual 
fishing effort appears to be expended in the bays and other open water areas as opposed to wetland areas.

A current estimate reveals that the 118,000 acres of Lake St. Clair, which is situated on the United States side, experiences a sport fishing use rate of 20 angler days/acre/year (personal communication, Ron Spitler). Again employing the angler day value of $\$ 9.72$, this amounts to $\$ 195$ per water acre/year of economic value. However, if the angler day figures from Table 47 are employed-$1,996,990$ angler days from Michigan waters of Lake St. Clair, then a use rate for the 118,000 acres of 16.92 angler days/water acre/year is obtained, for an economic value of $\$ 165$ per water acre/year in Lake St. Clair.

Several charter boat captains feel that somewhat more fishing activity occurs on the Canadian side than on the American side of the lake. This may be a response to overcrowding and overfishing or to the environmental deterioration occurring along western Lake St. Clair.

The non-salmonid sport fishing of carp, catfish, bullheads, yellow perch, walleye, and white bass is common along the Detroit River. Salmonid fishing opportunities are also present because of the stocking of chinook salmon and steelhead trout in the river since 1973 (Scott, 1977, p. 2). Creel census data during the period 1953 through 1955 revealed that the yellow perch fishing was declining, and that game fish constituted only 13 percent of the catch, whereas panfish and coarse fish accounted for 35 and 52 percent of the total catch, respectively (Fukano, 1956). At present the fishing of carp, catfish, bullheads and panfish in the Belle Isle area by Detroit urban fishermen is particularly intense. There are 14 shore sites and 1 pier as well as 8 boat launching facilities which provide angling opportunities along the Detroit River for Metro-Michigan fishermen. 
Sport fishing in the coastal wetlands of Monroe County along western Lake Erie has deteriorated considerably during the past few decades. Yellow perch was and to some extent still remains the most popular species along the nearshore area (Great Lakes Basin Comm., 1975a, p. 168). The current water quality at the mouth of the Raisin River is so degraded that a sport fishery for species other than carp is not possible at this time (ibid., p. 187). Muck areas in Maumee Bay negate the existence of fish life and prevent the migration of anadromous species (ibid., p. 177). Since the early $1960^{\prime}$ s, carp archery carnivals have been held at Pointe Mouillee which attract up to 4,000 participants annually (Schemenauer, 1963, p. 3).

At present there are two shore sites for sport fishing along coastal Monroe County. One is located at the State Game Headquarters at Pointe Mouillee along the lower Huron River, while the other is a public boat launch site near the Whiting power generating plant near Erie, Michigan. Bullheads and carp appear to be the primary species caught by bank fishermen along the lower Huron River. At the site near the Whiting plant, many sport fishermen walk along the shoreline to the hot water discharge canal and fish from shore for catfish, white bass, freshwater drum, and carp. On several occasions, during weekends, the authors have observed 30 to 40 fishermen both on shore and in small boats fishing near the discharge canal. It is estimated that 1,000 angler days per year are expended at this site.

As discussed above, the coastal wetlands vary considerably as to their value to sport fishing (Table 48). Part of this variation may be due to habitat quality and part to the difficulty of separating the open-water catch from the wetland harvest. However, as indicated in the section on spawning, most of these warmwater species 
TABLE 48

ESTIMATED ECONOMIC VALUE OF COASTAL WETLANDS TO SPORT FISHING, SELECTED COASTAL AREAS, IN MICHIGAN, 1977

\begin{tabular}{lc}
\hline Wetland Area & Value per Acre/Year \\
\cline { 2 - 2 } Lake St. Clair Wetlands & $\$ 2,284 *$ \\
(U. S. side only) & 429 \\
Saginaw Bay coastal wetlands & 374 \\
Harsens Island, St. Clair & $\frac{56}{286 * *}$ \\
River delta wetlands & \\
Little Bay de Noc wetlands & \\
AVERAGE & *Includes all waters of Lake St. Clair as well as the \\
Wetlands & The first entry, Lake St. Clair wetlands, was not in- \\
cluded in the average calculation of this statistic.
\end{tabular}

are at least indirectly dependent on the coastal wetlands. Another factor influencing the sport fishing use rate appears to be the proximity of the area to urban centers. Lake St. Clair, because of its proximity to metropolitan Detroit, has extremely high participation rates and sport fishing value. If the Lake St. Clair wetlands data are excluded (see first row in Table 48), then an average economic value of sport fishing, based on the three wetland areas, is estimated to be $\$ 286$ per wetland acre/year.

Projections of sport fishing participation rates have been made by the Great Lakes Basin Commission for the seven planning subareas in Michigan for the years 1980 , 2000 and $2020 \mathrm{~A}$. D. If the resident participation generated within a planning subarea is compared to the total participation, which accounts for imported and exported demand, then regions with insufficient angler opportunities can be identified. At present, southwestern Michigan, southeastern Michigan, and the Saginaw Bay-Thurnb area cannot supply their residents with sufficient sport 
fishing opportunities (Great Lakes Basin Comm., 1975a, pp. 115, 155 and 189). Projections to 1980 indicate that in the future the Upper Peninsula and northern portion of the Lower Peninsula must absorb much of this outside demand (Table 49). Currently, 30 percent of the demand in southeastern Michigan and 40 percent in southwestern Michigan is supplied by planning subareas in northern Michigan (ibid., pp. 115 and 189). As resident demand increases in the Saginaw Bay-Thumb region, increased pressure will be exerted on the Saginaw Bay fishery as well as on those further north.

Latent demand is another factor which should be considered when evaluating the future status of sport fishing. In southeastern Michigan, latent demand, or excess demand as it is otherwise referred to, could more than double the projected resident sport fishing demand in 1980 (ibid., p. 190). Throughout southern Michigan, the cost of providing more fishing opportunities in inland areas must be weighed against the cost of developing alternate opportunities in Lake St. Clair, Saginaw Bay, other Great Lakes, or in northern Michigan. The mobile, relatively affluent segment of the population may be satisfied by outmigration opportunities, but the less mobile may be defranchised from participation. 


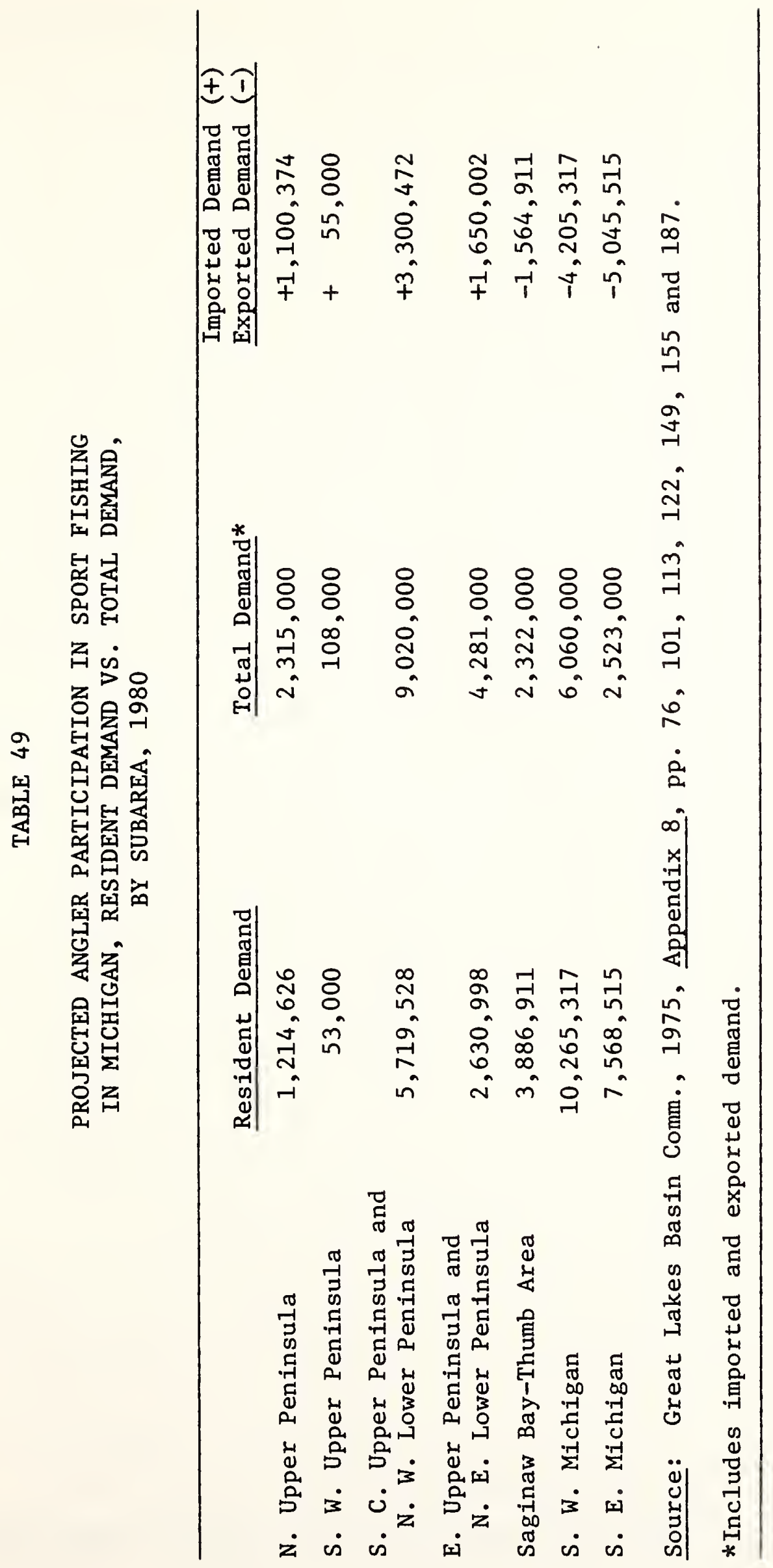


CHAPTER SIX

NONCONSUMPTIVE WETLAND VALUES

In this chapter, selected nonconsumptive uses, or non-fishing and non-hunting uses, of coastal wetlands are examined. Many unique values cannot be assigned a dollar value; however, they are recognized as important contributors to the wetland and the adjacent environments. Conversely, many birds and other unique flora and fauna use coastal wetlands to maintain their normal life functions. It is perhaps these unique values which draw many visitors to the state's wetlands. The recreation values are examined and a dollar value estimated.

An approach in determining the value of a wetland is to document certain unique characteristics. Wetlands, which are outstanding and hence merit preservation, include areas that have significant geological and/or biological traits which are invaluable for scientific research and education (Larsen, 1976, p. 7). As outlined, an outstanding geobotanical wetland unit involves the juxtaposition, in sequence, of several seral stages of hydrarch succession. In addition, diversity may be considered a unique characteristic of a wetland. A wetland supporting a wide spectrum of wildlife, such as fish, birdlife and mammals, is indeed exceptional.

A second entity for the identification of an outstanding wetland is based on its fauna and flora. Three criteria which would classify a wetland as outstanding are:

1) The presence of rare, restricted, endemic or relict fauna or flora,

2) The presence of flora of unusually high visual quality and infrequent occurrence, 
3) The presence of flora or fauna at, or near, the limits of their range.

UNIQUE GEOMORPHOLOGICAL AND BIOLOGICAL VALUES

Along the Great Lakes, normal wetland succession is disrupted as a result of lake level fluctuations. However, vegetation zonation from submersed aquatics to shrubs and finally to upland hardwoods is present and shifts occur as lake levels change. Examples of such a basic ecological principle as determined in the literature with few exceptions is not well researched or documented.

Figure 23 demonstrates that such a spectrum occurs in the St. Clair delia (Jaworski and Raphael, 1976). It may be expected that similar vegetation profiles occur on other wide, undisturbed wetland zones such as at Little Bay de Noc and perhaps the Au Gres wetlands.

Compared to other Great Lakes' coasts, the St. Clair delta has been reasonably well researched by geographers and geologists (Jaworski and Raphael, 1973). Based on the literature, the delta is the largest in the Great Lakes' basin and is characterized by unique geomorphic features and hence merits preservation.

ENDANGERED, THREATENED, AND RARE SPECIES

In Michigan, an Endangered Species Program was organized under the authority of the Endangered Species Act of 1973 (P. L. 93-205). The first state lists on endangered and threatened species were presented to the Natural Resources Commission in February, 1976. The data on endangered and threatened species documented in this section are based upon the proposed annotated list of plants and animals resident in Michigan that is proceeding toward final approval in accordance with the Administrative Procedures Act. Location of the fauna and flora was primarily obtained from environmental impact statements. The location of most threatened birds was largely taken from "The Mississippi Flyway Waterfowl Habitat Recon- 

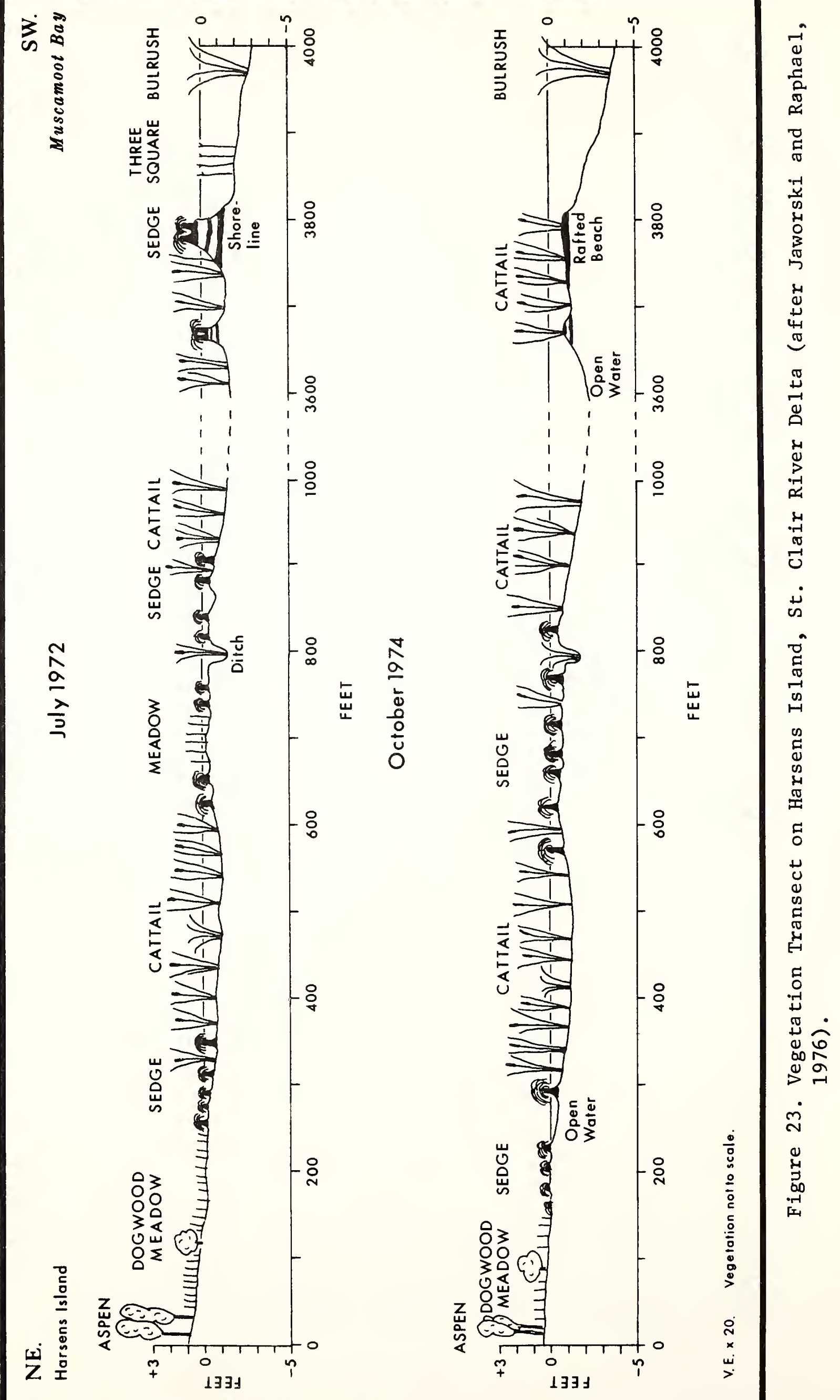
naissance" (Martz, 1976). Floral data on endangered. threatened and rare vascular plants have recently been documented by Wagner et al. (1977) for the DNR.

For convenience, two tables are presented. Table 50 includes coastal endangered, threatened, and rare fauna observed and documented in the literature. Table 51, largely determined from Wagner et al. (1977) locates endangered, threatened, and rare plants in coastal Michigan. The latter table is not limited to wetland flora but includes plants which have been documented on islands (e.g., Isle Royale) and on coastal cliffs. In some instances, the flora which were identified on sandy shores and dunes are included as well. Many coastal wetlands exist and are maintained because of barrier beaches (e.g., Tobico). Such barriers are morphologically related to the adjacent wetland and may be part of the wildlife habitat, thus the flora are included.

Based on Table 50 and 51 certain wetlands of the state do possess endangered, threatened and/or rare fauna and/or flora. The wetlands of the lower Detroit River and western Lake Erie contain flora and fauna which are not only threatened, but are endangered, such as the American 1otus. Similarly, in the St. Clair River delta a similar cluster of endangered, threatened and/or rare species emerges. Other wetlands in Michigan where endangered or threatened species have been documented include: the south shore of Saginaw Bay (Quanicassee), Tobico, Epoufette Bay, Mismer Bay, Si. Martin Bay, Little Bay de Noc, Baie de Wasai, Nuns Creek and the Cheboygan Marsh.

As determined by Beaman (1977) and illustrated on Table 52, 38 percent of the probably extinct, endangered and threatened species occupy or have occupied aquatic and wetland habitats. Also as noted, more plants have probably been extinguished in this habitat than any other habitat. Assuming that the proposed list of endangered 


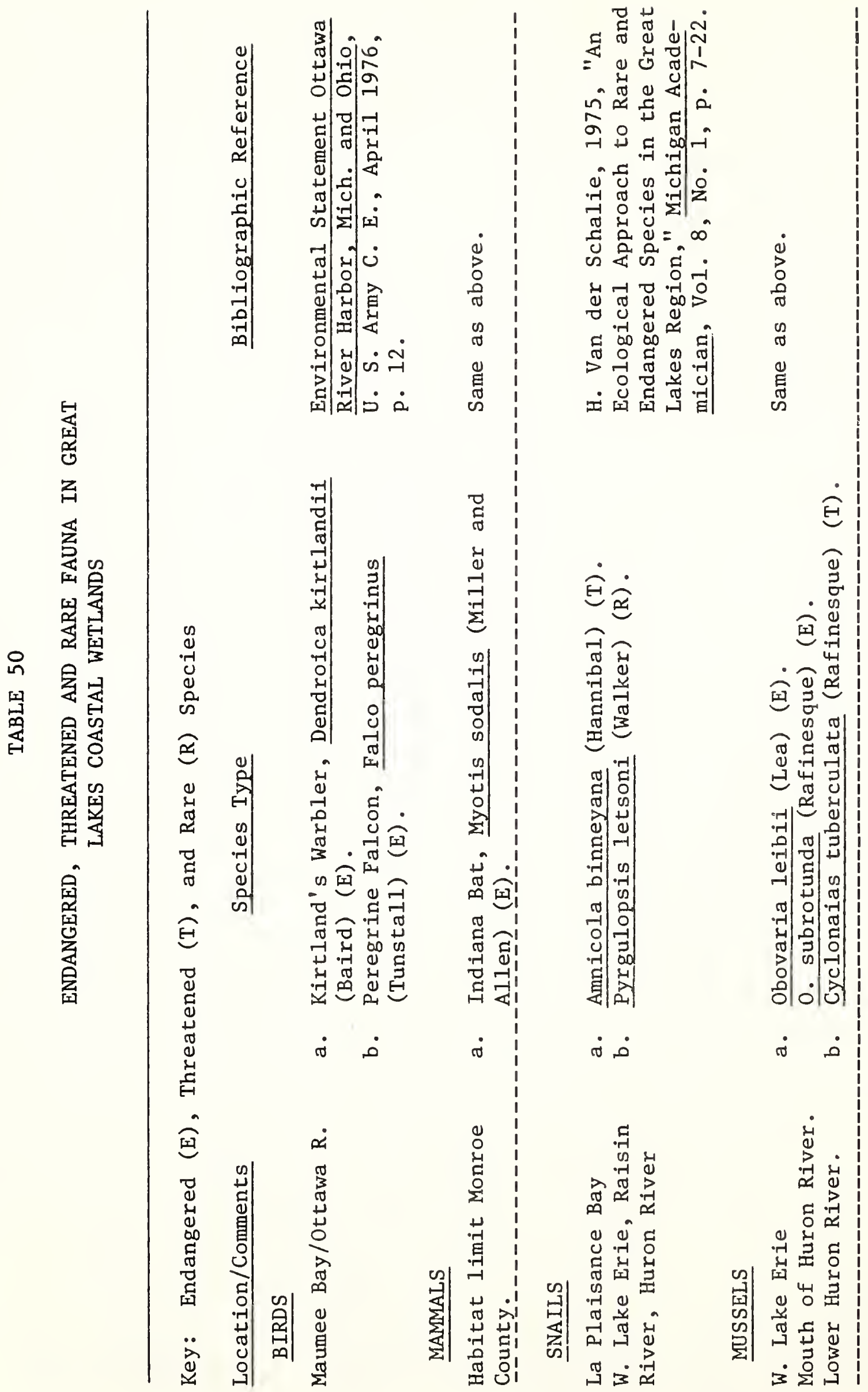




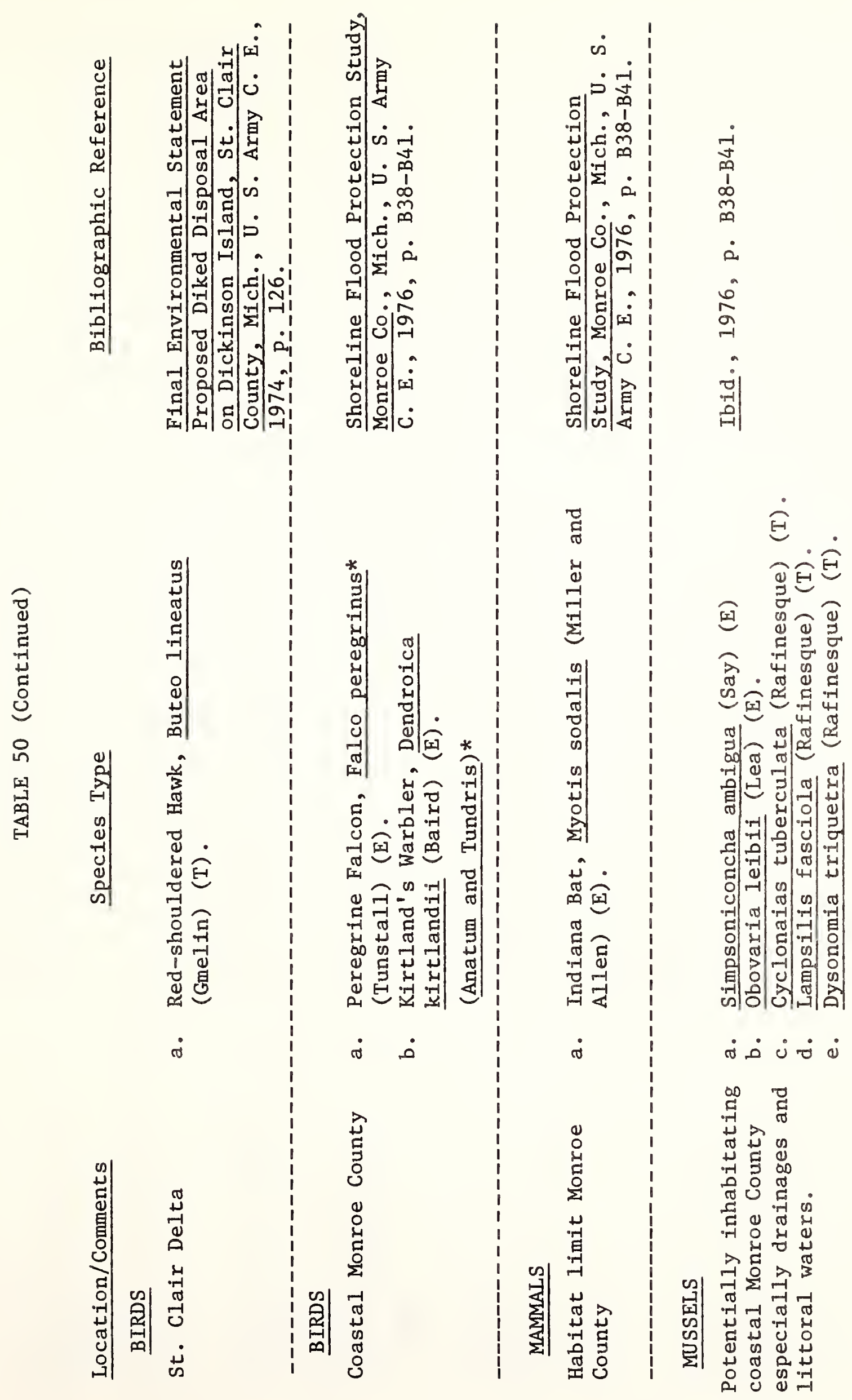



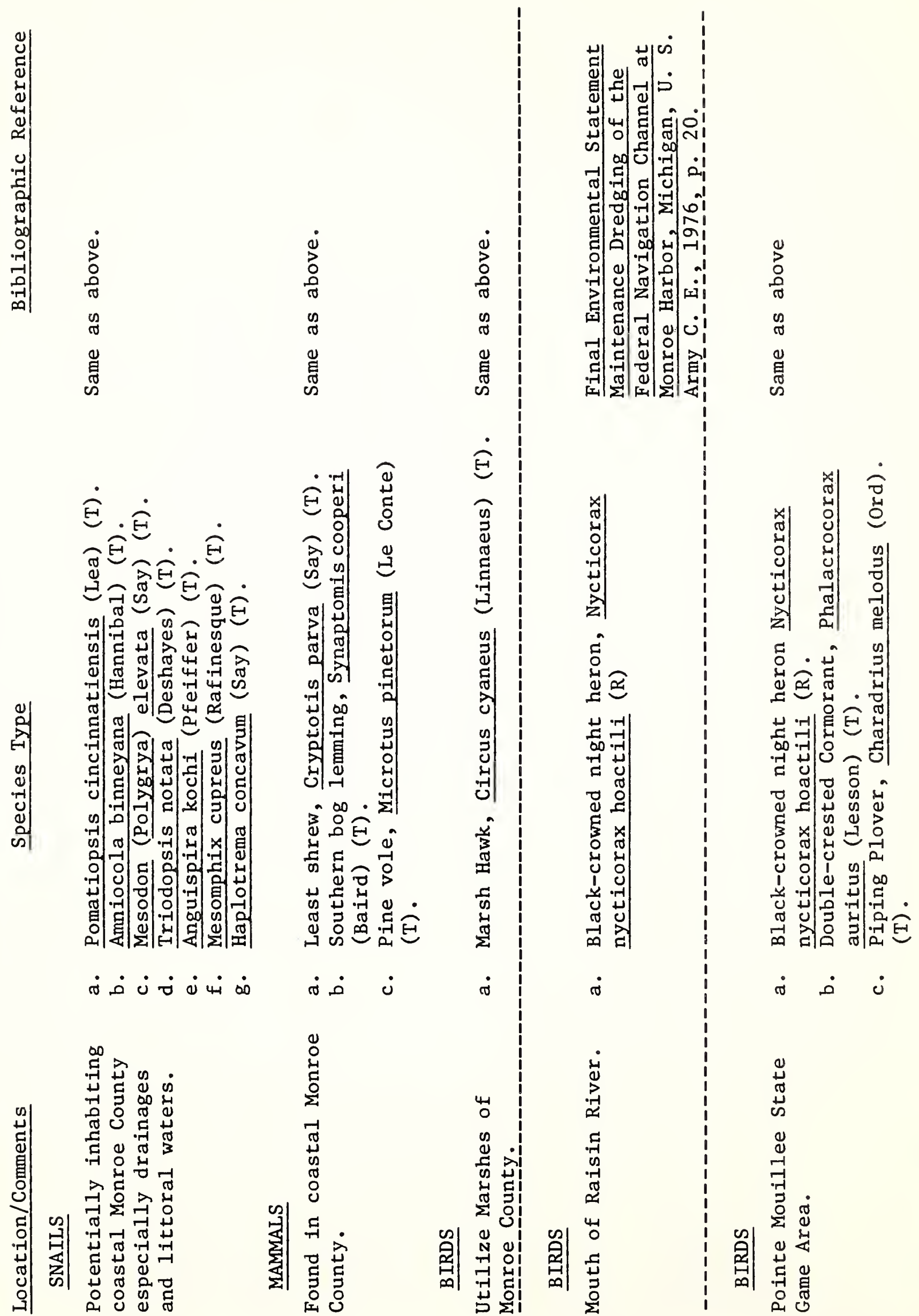


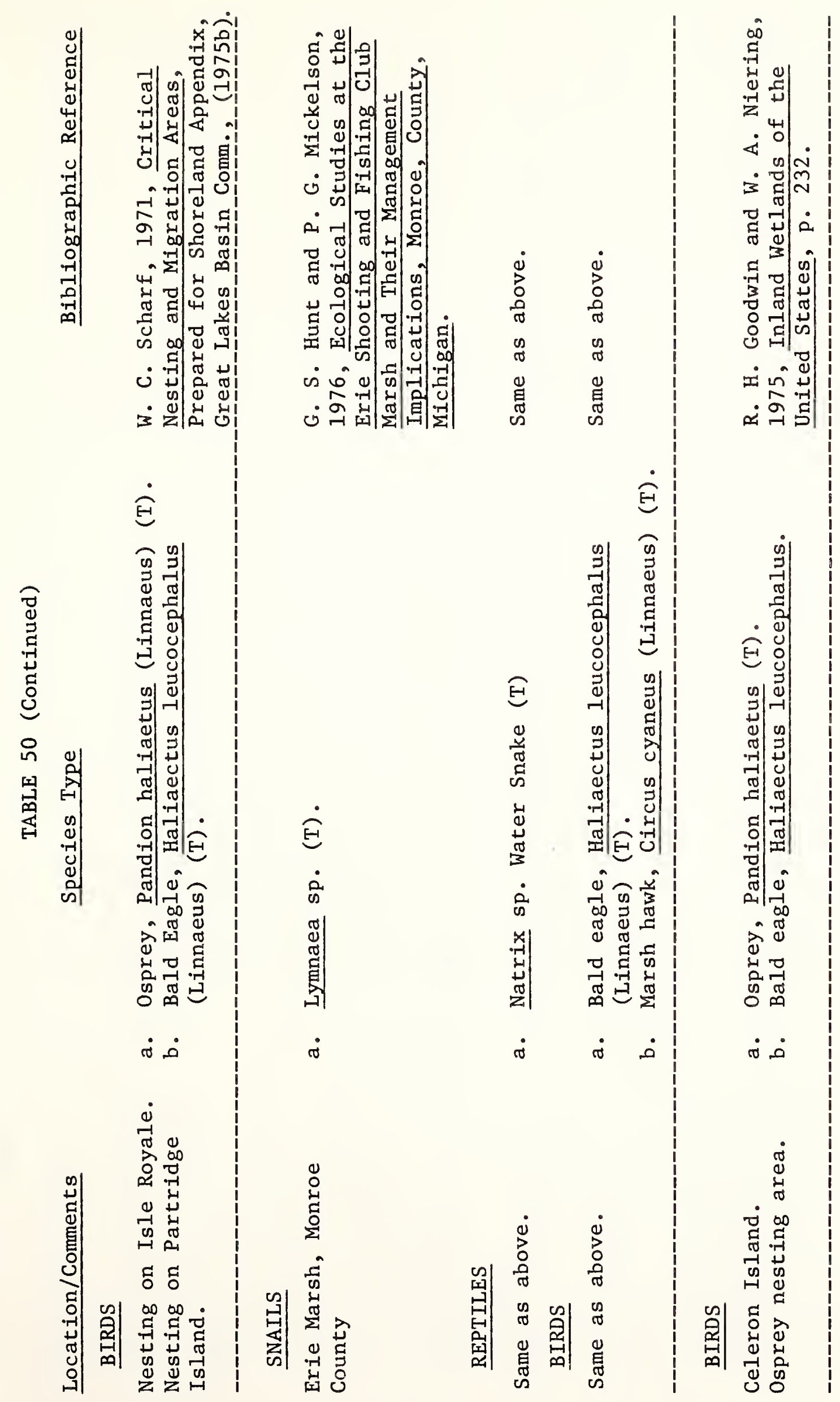



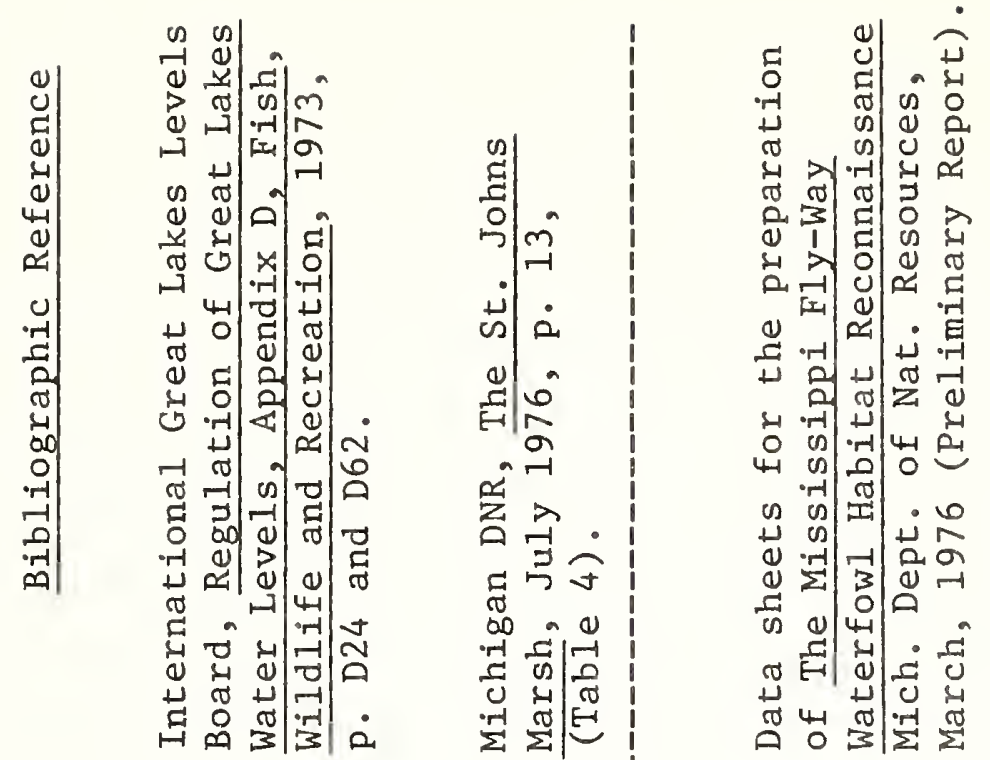

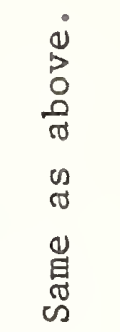

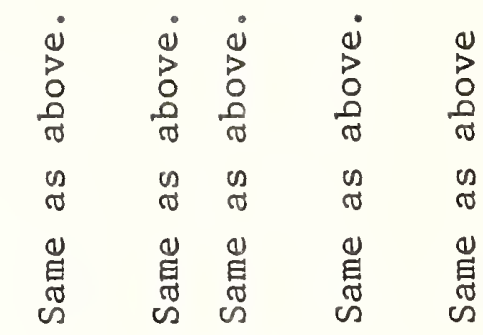
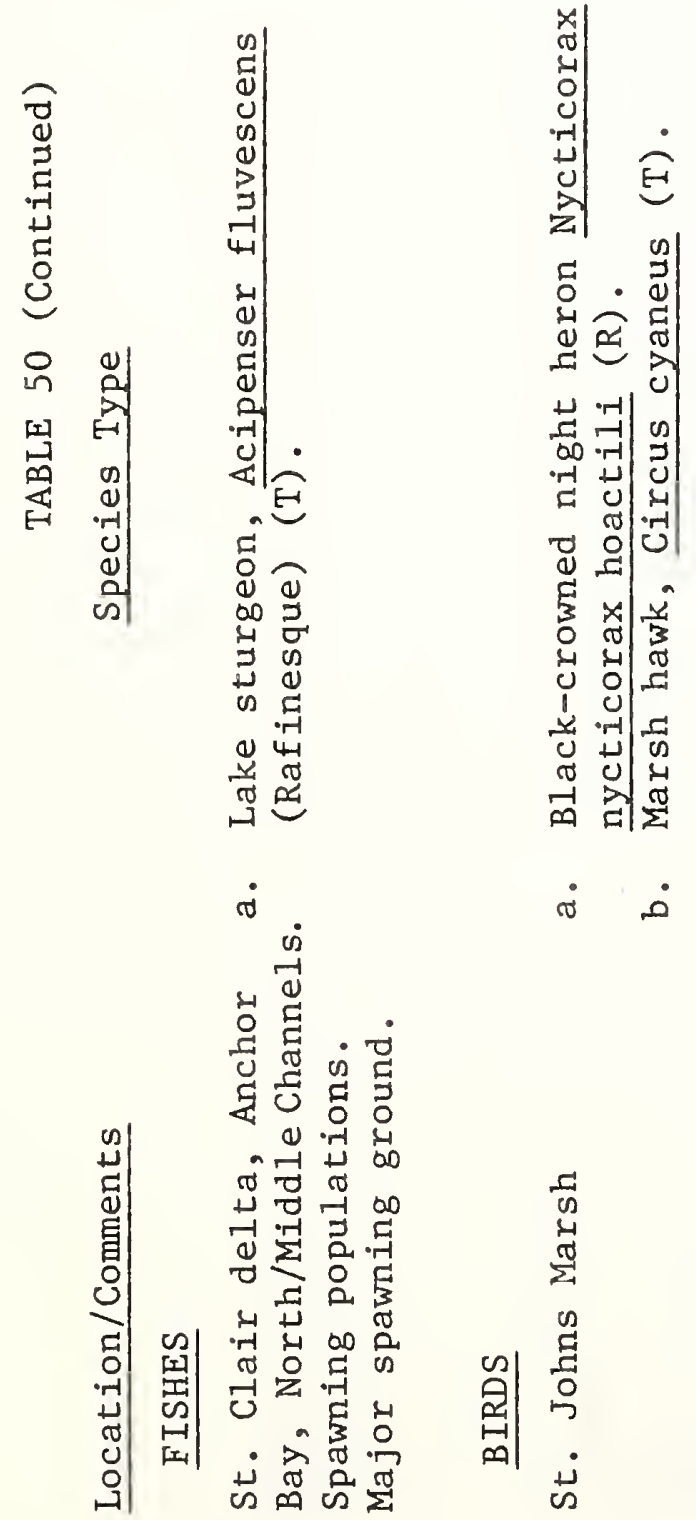

$\dot{\dot{\Xi}}$

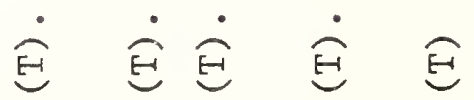

ช.

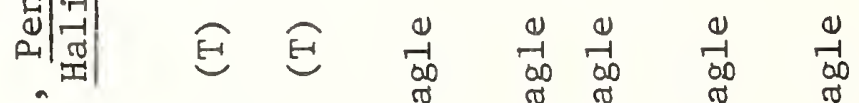

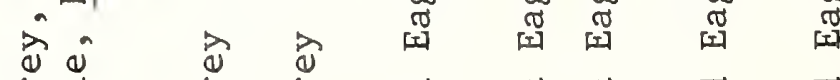

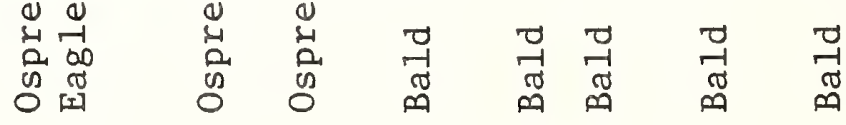

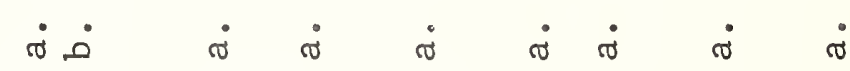

21 出

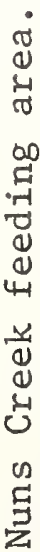

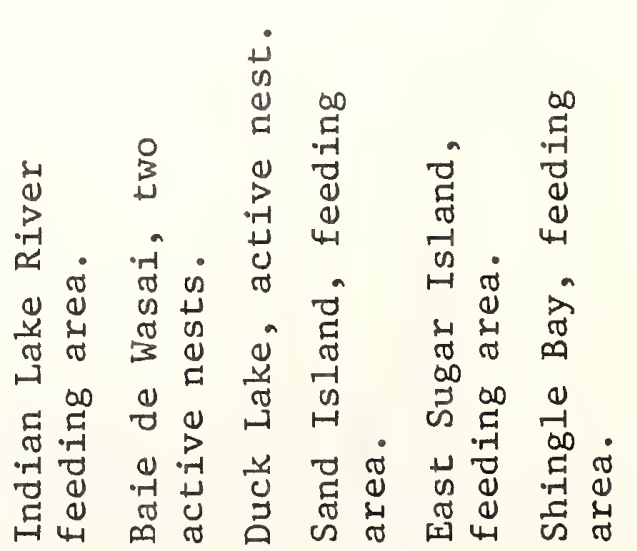




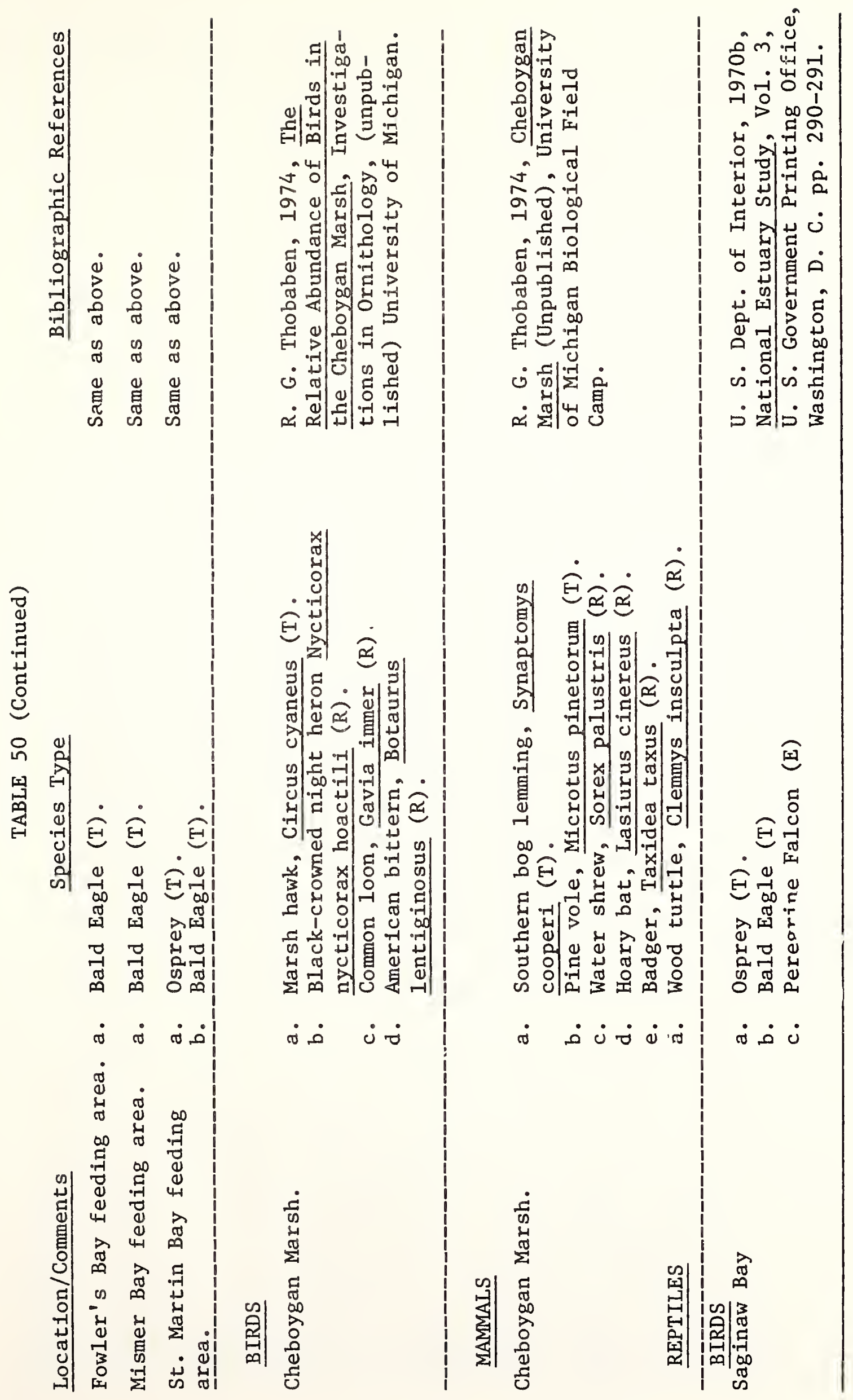




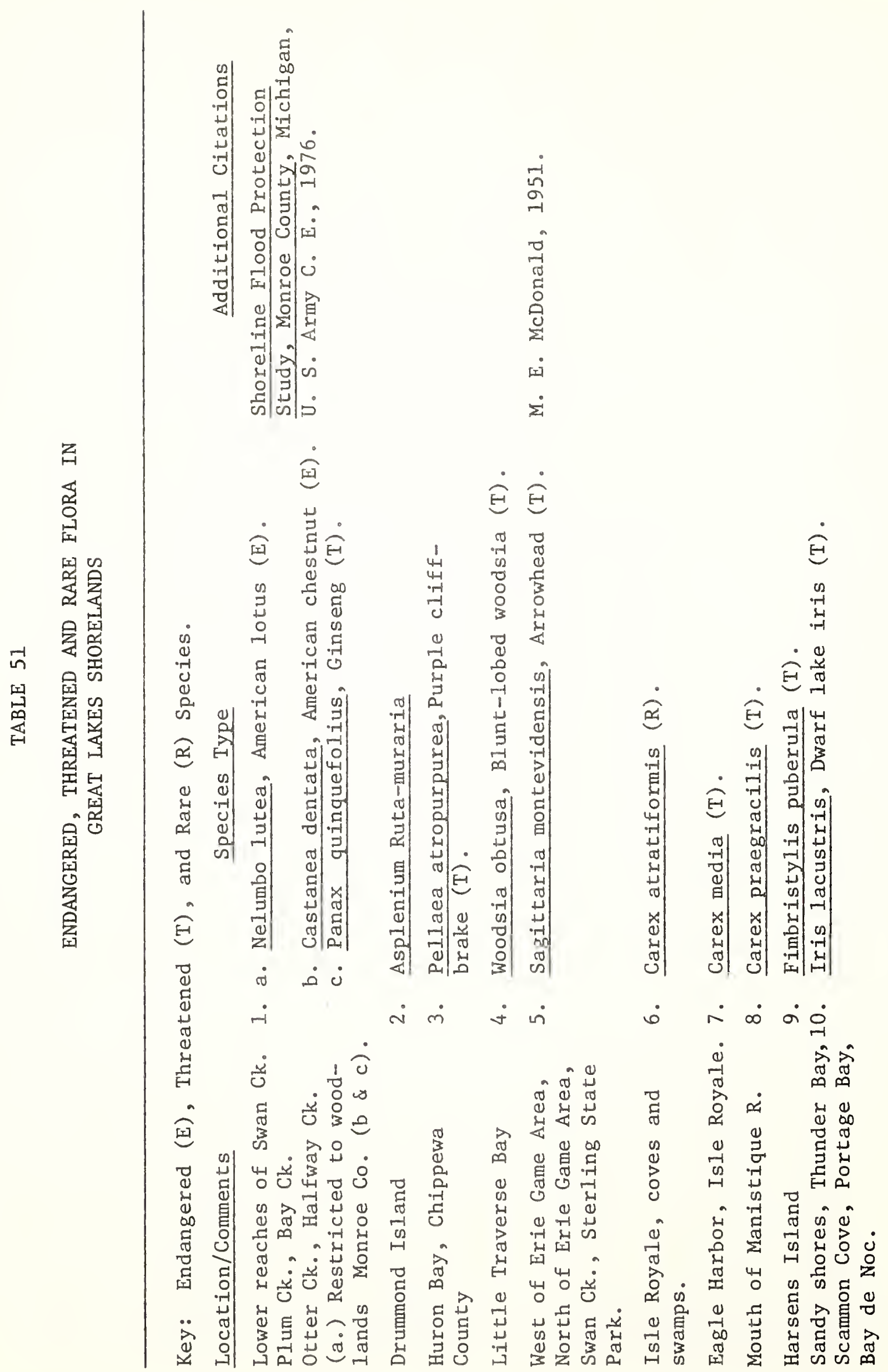




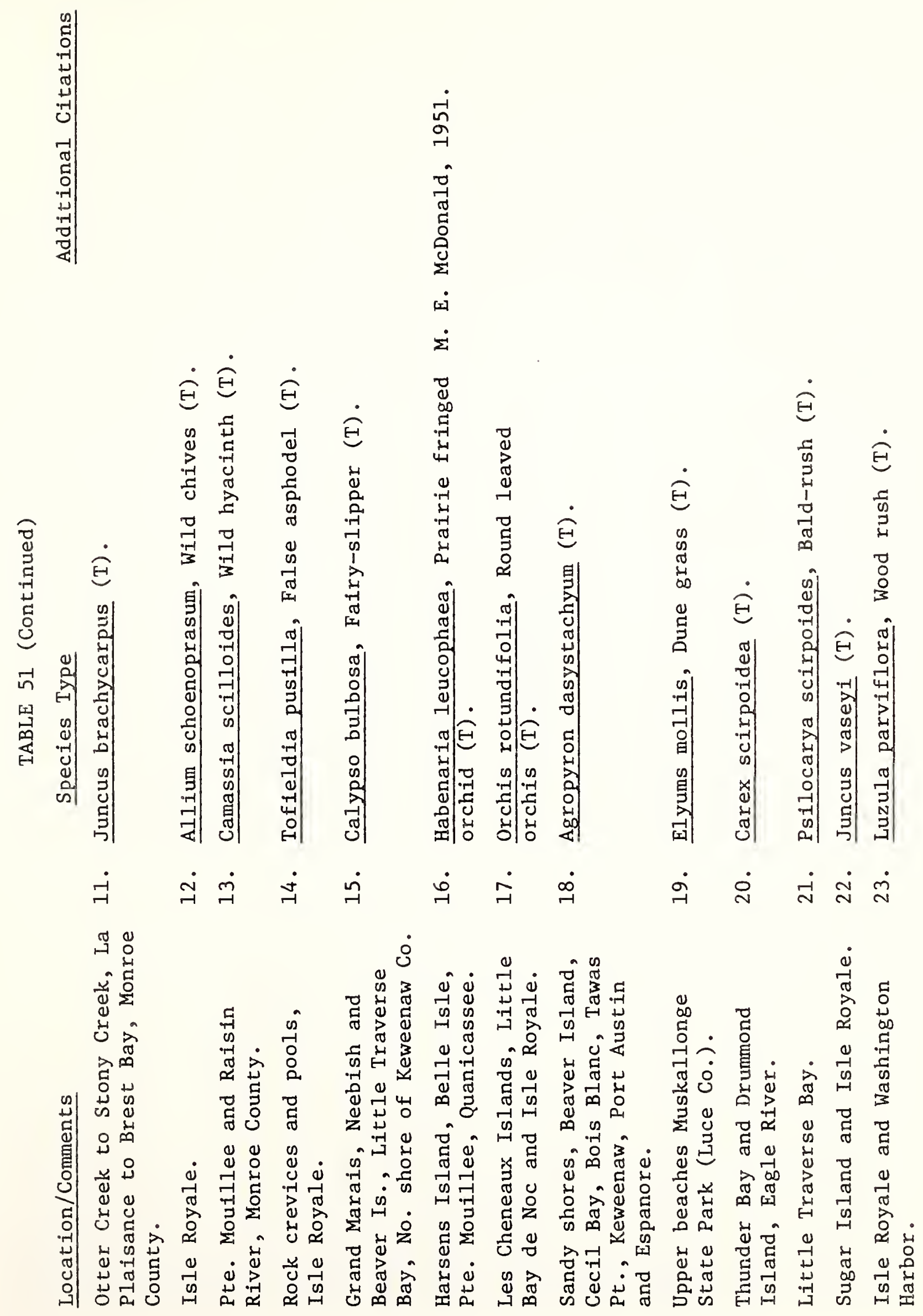




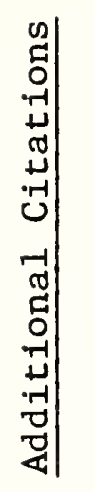

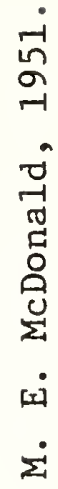

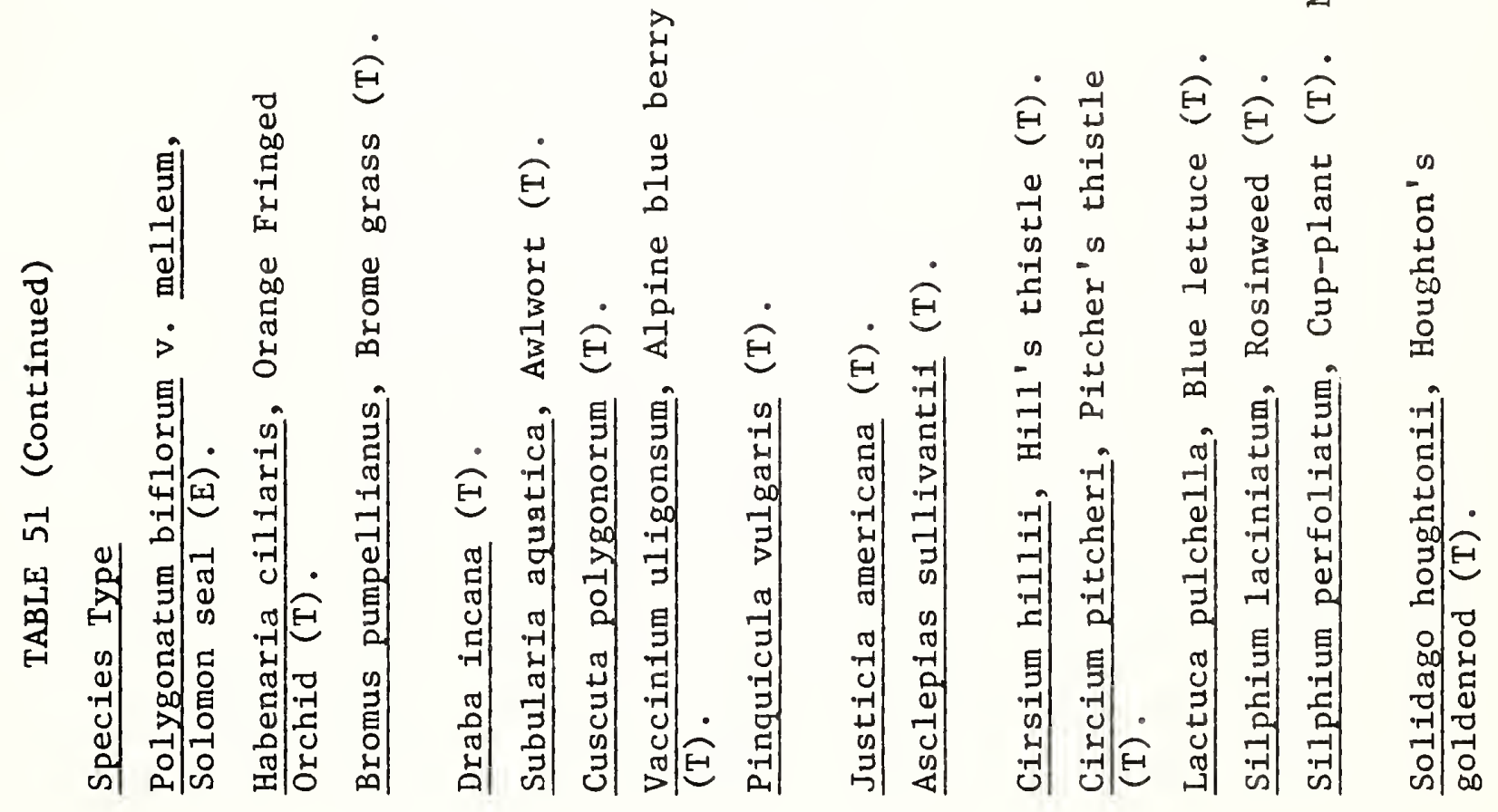

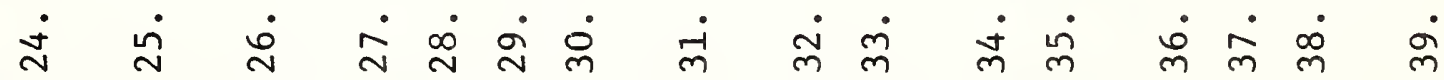

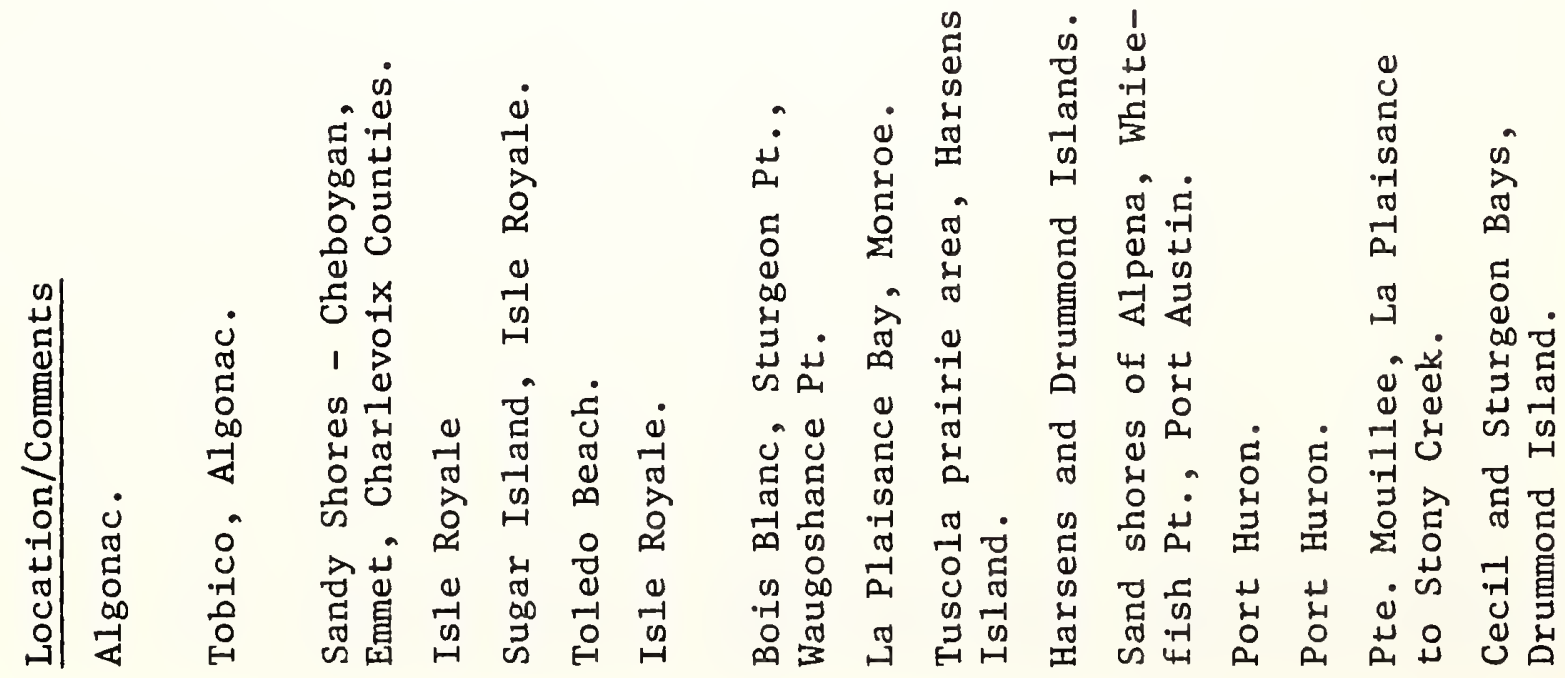


0.

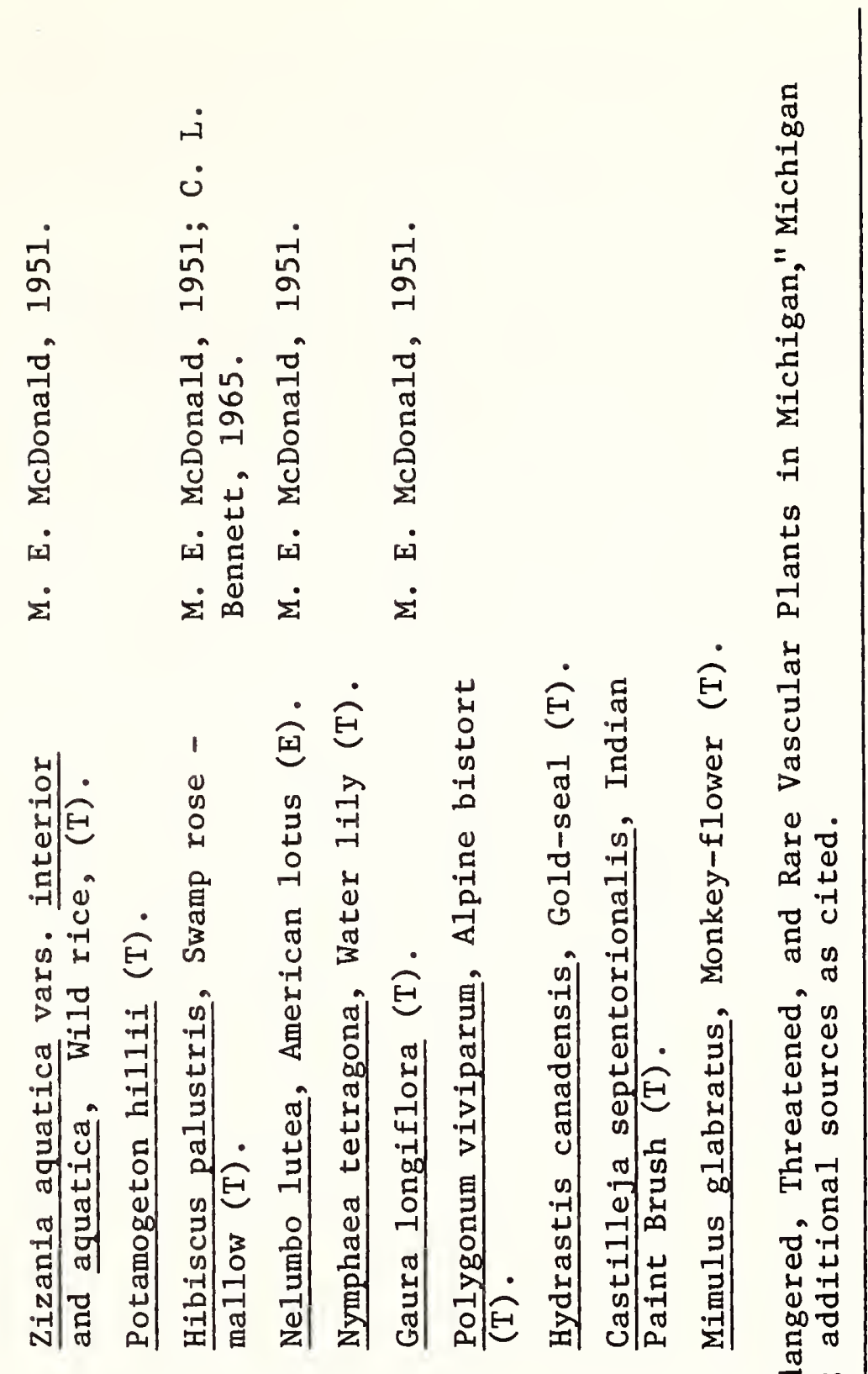

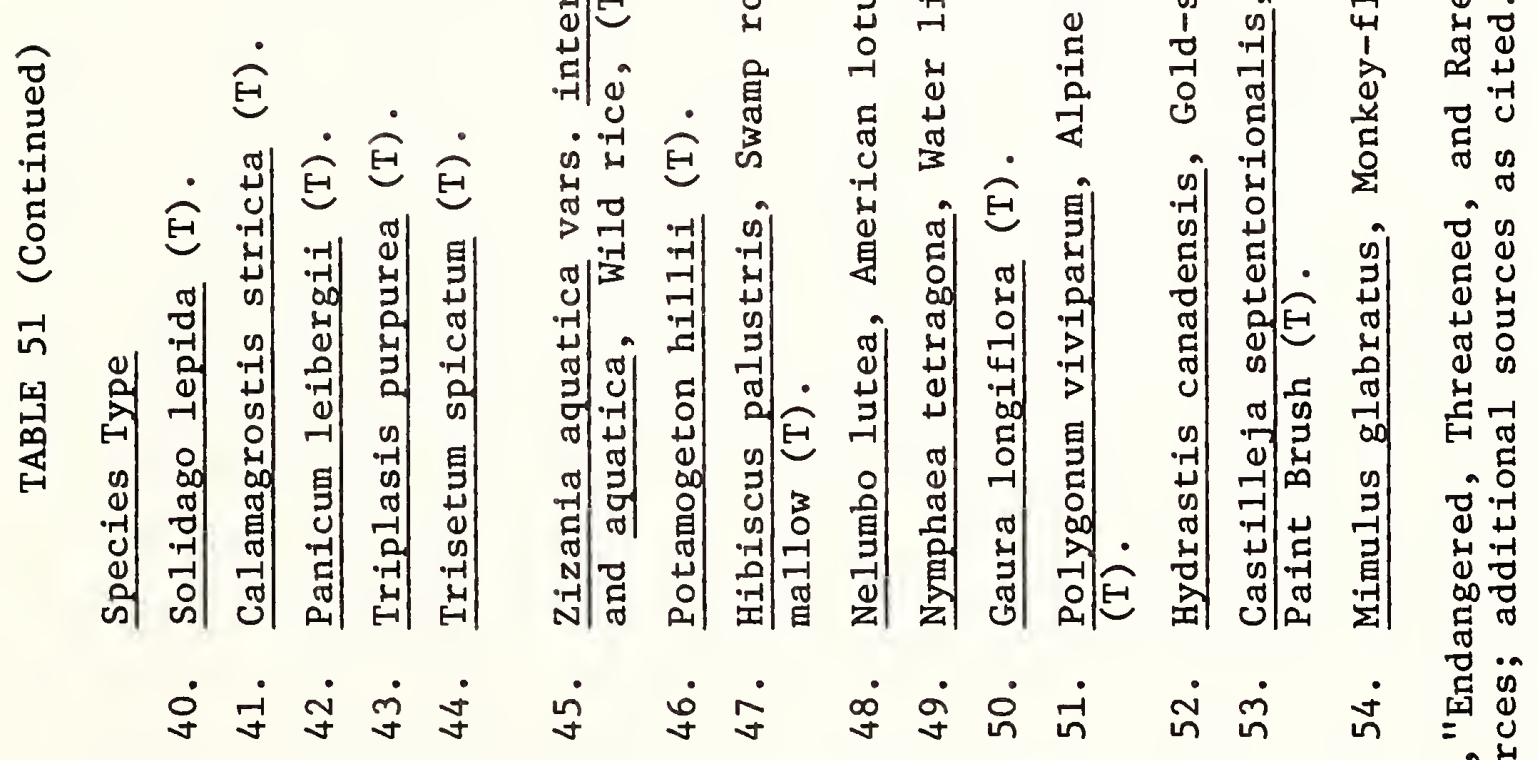

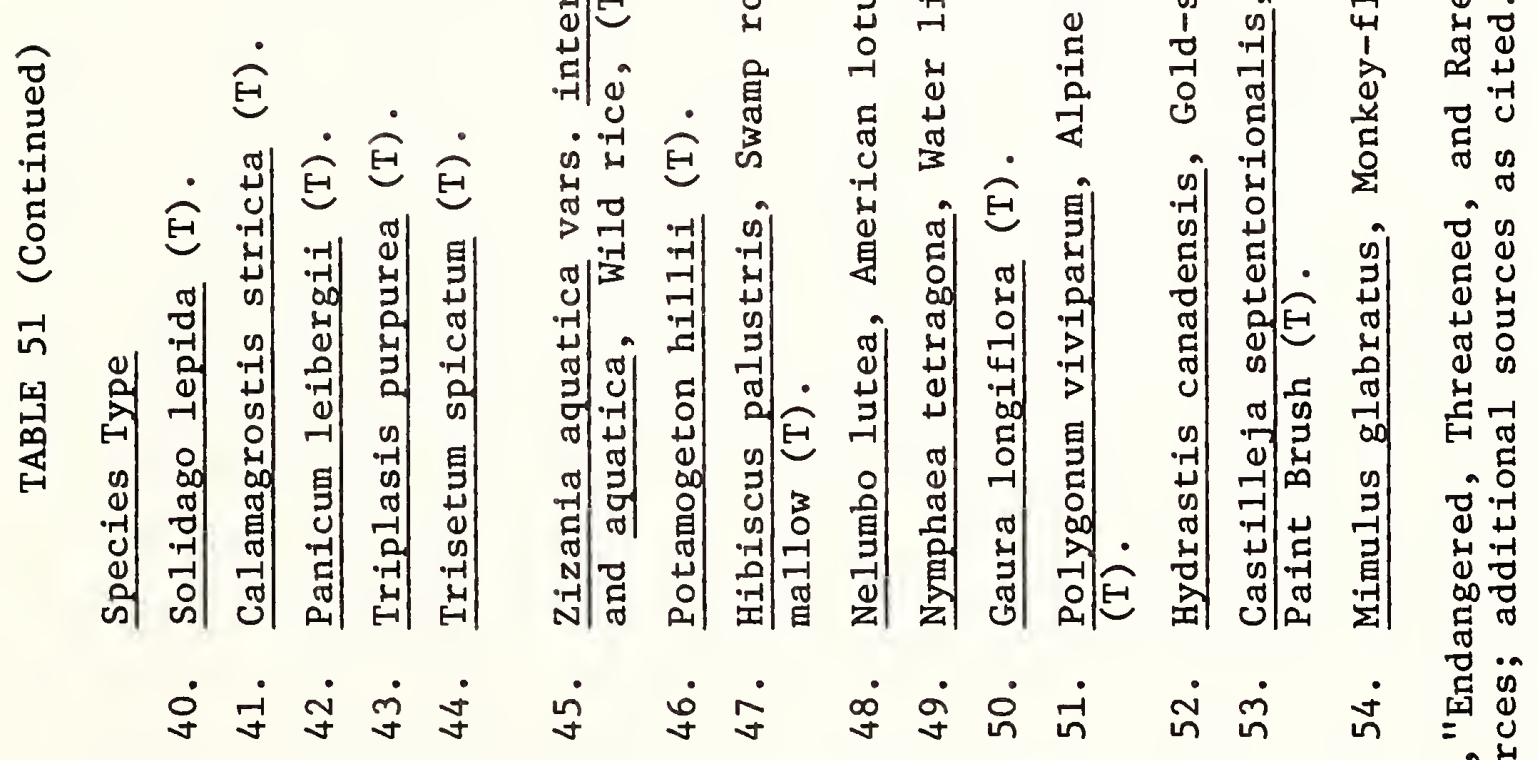

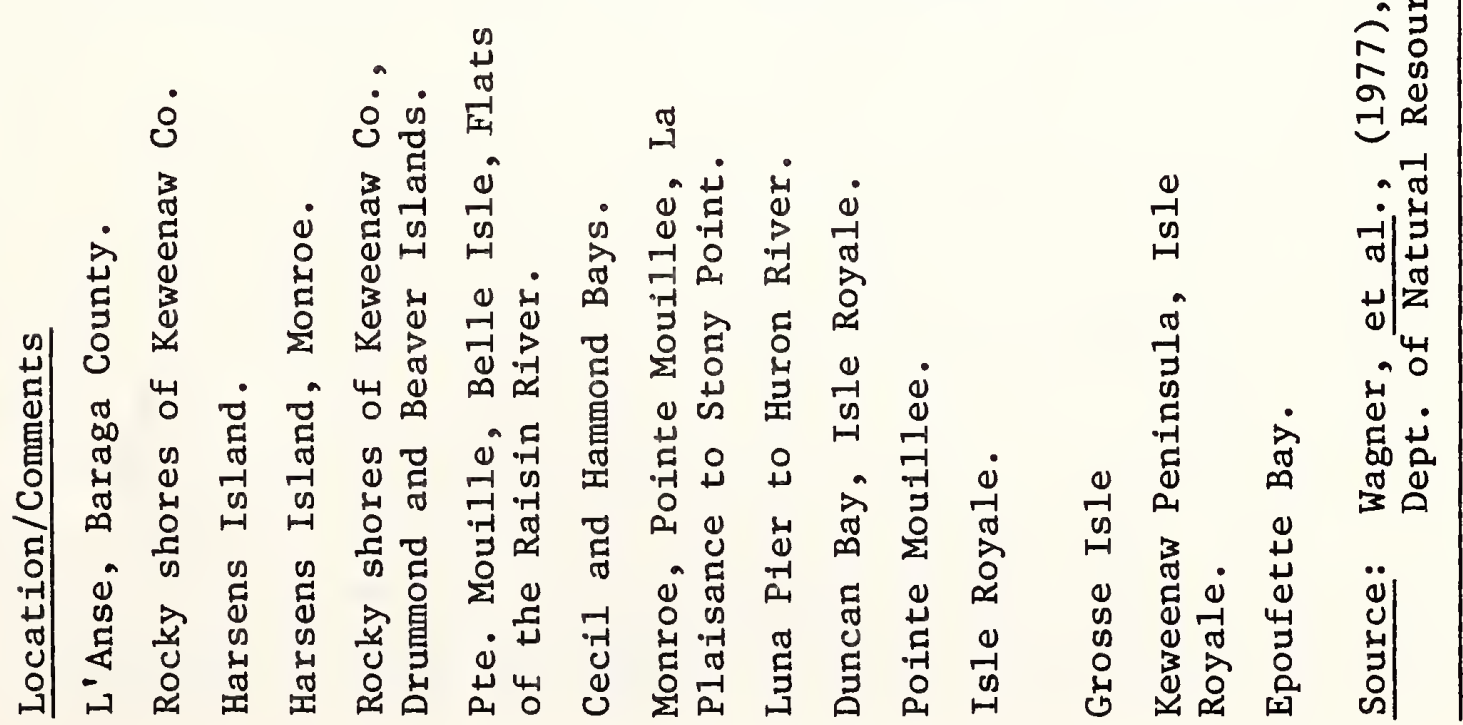


and threatened plants and animals is approved and Larson's criteria for outstanding wetlands is acceptable, unquestionably high nonconsumptive value may be assigned to these selected wetlands.

NESTING AND MIGRATION OF SHOREBIRDS, PASSERINES AND BIRDS OF PREY IN GREAT LAKES SHORELANDS

As determined by Scharf (1977), the principal avifauna of the Great Lakes shorelands are documented in Table 53. It is evident that a diversity of habitats is required for feeding and resting of migratory birds and for nesting cover for the resident populations. The habitat varies from isolated wooded areas and herbaceous cover preferred by the herring gulls to marshland requirements of the black terns and the great blue herons.

Nesting sites of the birds occupying shorelands, have substrates varying from beach grasses and shrubs, to cobbles and gravels, to spoil disposal sites. Two coastal marshes in Michigan appear to be most significant to colonial nesters per se. At Portage Point, 64 common tern nests and three green heron nests occur within the wetland (ibid., p. 76 and 84). Other migratory birds breeding in Michigan include the killdeer, piping plover, upland sandpiper, spotted sandpiper, Wilson's phalarope and the American woodcock (Sanderson, 1977, p. 306-308; Cottrille, 1957, p. 27). An important breeder in the wetlands is the mute swan. Koechlein (1971, p. 2) has identified 72 nests situated in cattails, sedges, and bulrushes of the Grand Traverse Bay area. He also determined that 275 to 300 swans utilized the ice-free areas of Grand Traverse Bay during January, February, and March, 1970 (ibid., p. 3). Cottrille (1957, p. 27) has mapped the breeding sites of the piping plover in Michigan. The more significant coastal sites of the plover occur in Monroe, Macomb, Huron, Schoolcraft and Alger Counties. On the lower Detroit River, Celeron Island provides 


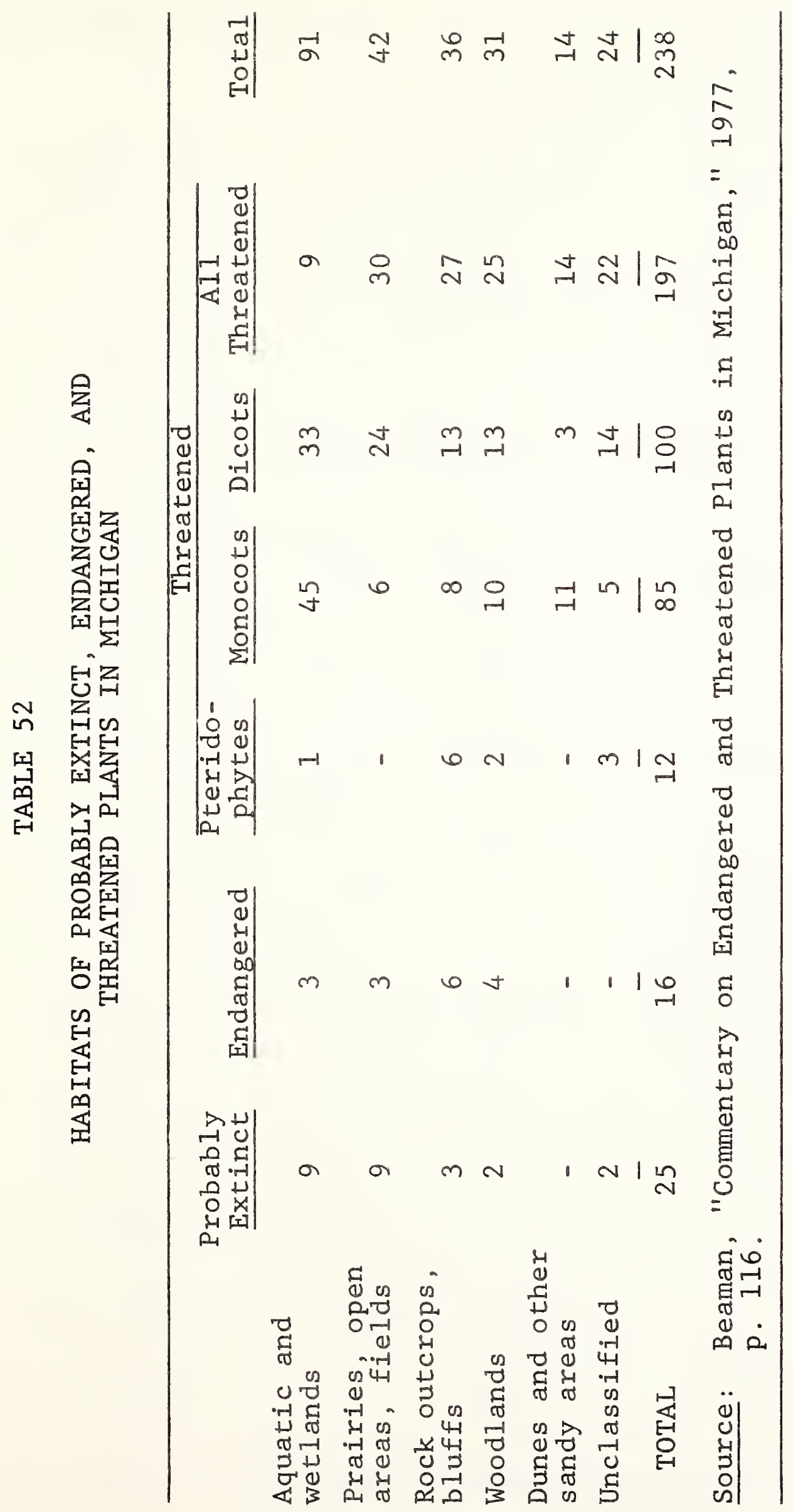


TABLE 53

AVIFAUNA IN THE COASTAL GREAT LAKES

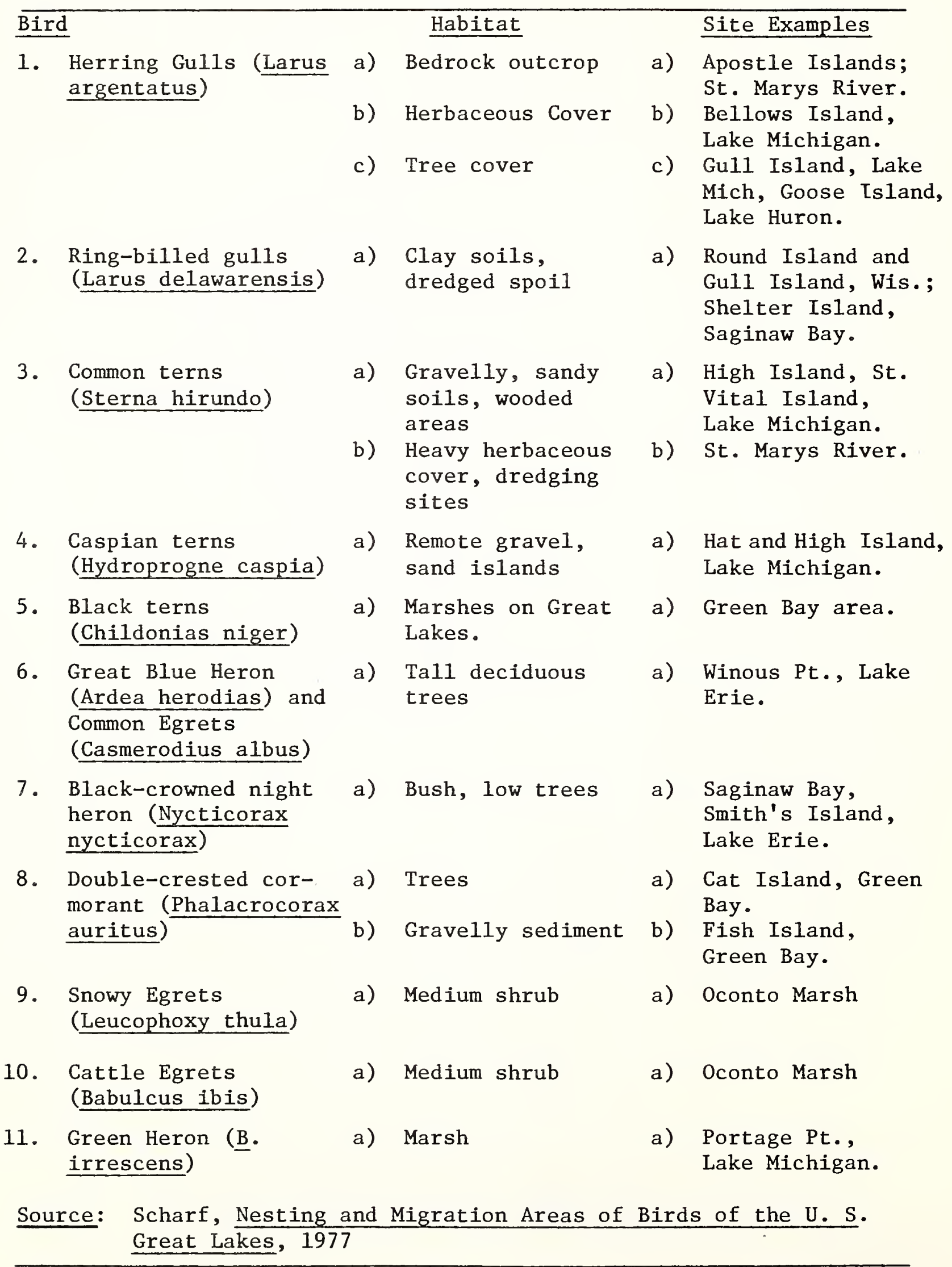


nesting habitat for the osprey (Goodwin and Niering, 1975, p. 232). Also, according to these authors bald eagles and sandhill cranes visit the island (ibid., p. 232). Just to the south at Plum Creek, a black-crowned night heron heronry has been identified and mapped (Hoffman and Prince, 1975, pp. 95-99).

Table 54 identifies significant migration sites and staging areas of passerines, raptors and shorebirds. Important focal and funneling points are mainly islands (e.g., South Fox Island) and peninsulas (Figure 24) jutting into the Great Lakes (e.g., Keweenaw Point). However, wetlands such as the Elberta Marsh, the Muskegon River Mouth and Saginaw Bay are also significant migration sites.

The value of wetlands and adjacent areas is variable with regard to migration. As noted in the table below, the value of sites in Saginaw Bay and western Lake Erie has decreased due to damage to the vegetation by recent high water. Other wetlands, such as the Grand Haven marshes and the Elberta Marsh have also experienced similar high lake levels in the early 1970's, but have remained important migration sites. The latter coastal wetlands are protected by coastal dunes or barriers which prevent serious erosion of the wetlands. Also, the protective coastal barrier, if vegetated, probably provides additional cover for migratory and nesting birds. Other Important Migratory Birds

As noted in the introduction of this chapter, one important criterion for the identification of outstanding wetlands is the presence of fauna at or near the limits of the breeding range. Geographically, several migratory birds are at their range limits in Michigan. The list includes :

$\begin{array}{ll}\text { Virginia rail } & \text { King rail } \\ \text { Yellow rail } & \text { Common gallinule } \\ \text { Black rail } & \text { American coot }\end{array}$




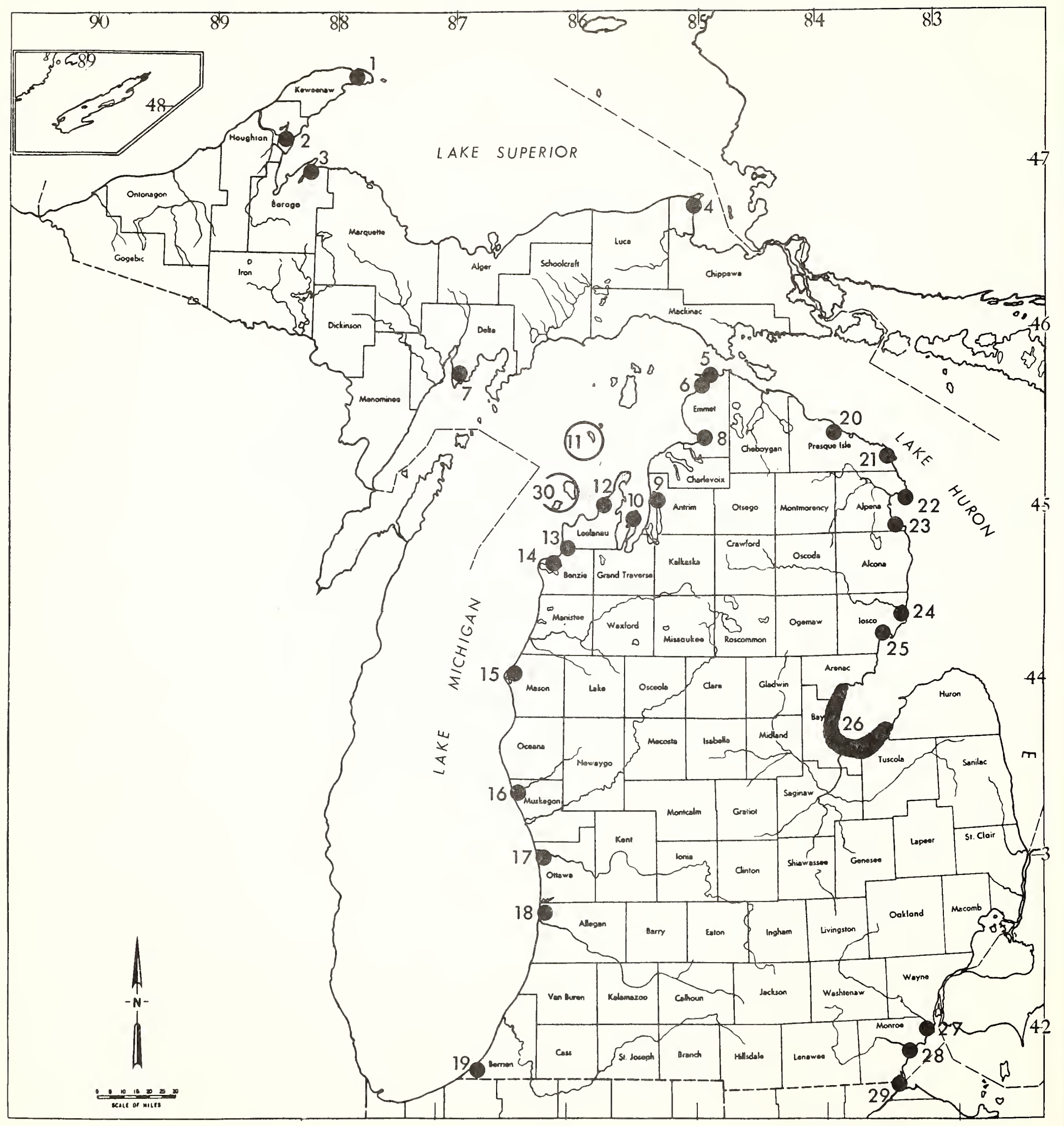

FIGURE 24--Migration sites of shorebirds, passerines and raptors, in Michigan (after Scharf, 1977). See Table 54 for site locations. 
TABLE 54

\title{
COASTAL MIGRATION SITES OF SHOREBIRDS, PASSERINES AND RAPTORS
}

\author{
Migration Sites \\ 1. Keweenaw Point \\ 2. Sand Point Marsh \\ 3. Point Abbaye \\ 4. Whitefish Point \\ 5. Shoreline west of \\ Mackinac City \\ 6. Waugoshance Point \\ 7. Garden Peninsula \\ 8. Harbor Springs \\ 9. Ptobego Marsh \\ 10. 01d Mission Point \\ 11. South Fox Island \\ 12. Sleeping Bear Dunes/ \\ Benzie State Park \\ 13. Pointe Betsie \\ 14. Elberta Marsh \\ 15. Ludington State Park \\ (Hamlin Lake) \\ 16. Muskegon River mouth \\ 17. Grand Haven Marsh \\ 18. Kalamazoo Lake and \\ Saugatuck Marsh \\ Comments \\ Ful1 spring migration site. \\ Concentration area for passerine and \\ shorebirds. \\ Concentration area for passerine and \\ hawks. \\ Spectacular migration focal point for \\ passerines, owls, common loons and hawks. \\ Funnelling point for spring migration, \\ especially for birds of prey. \\ Large numbers of shorebirds. \\ Major shorebird migration area. Heavy \\ raptor, waterfow1 and common loon flights. \\ Large numbers of passerines in fall and \\ spring. \\ Shorebird concentrations during low \\ water. \\ Large concentrations of passerine and \\ sma11 numbers of hawks in spring. \\ Northward extension of the South Manitou- \\ North Manitou migration route. \\ Large number of shorebirds during low- \\ water. \\ Seasonally heavy passerine and shore- \\ bird migrations. \\ Resident Canada geese; excellent shore- \\ bird, passerine and hawk migration \\ resting points. \\ Hawk, passerine, and shorebird migra- \\ tions; hawks and warblers in the spring. \\ Important for passerine, hawk and \\ shorebird migration. \\ Important for migrating King rails, \\ Virginia rails and migrating and nesting \\ Sora rails. Yellow-headed blackbirds \\ commonly seen here. \\ Very important as a stopover for large \\ numbers of passerine and shorebirds.
}


TABLE 54 (Continued)

Migration Sites

19. Grand Beach, Warren Dunes State Park

20. Calcite Flats

21. Presque Isle Point

22. North Point near Misery Bay

23. South Point on Thunder Bay

24. Au Sable Point

25. Tawas Point

26. Saginaw Bay wetlands

27. Pointe Mouillee

28. Sterling State Park

29. Woodtick Peninsula

30. North and South Manitou Islands

\section{Comments}

Major staging area for waterfowl, loons, grebes and shorebirds.

Large shorebird migration.

Fairly heavy passerine and hawk migration.

Passerine and hawk migrations.

Exceptional concentrations of nocturnal and diurnal passerine birds.

Mainly shorebird migration point.

Prime focal point for migration; some hawks, but large numbers of shorebirds and passerines.

Usefulness damaged by high water; very productive shorebirds and passerine birds in low-water years.

Point of departure for the great hawk migrations to Canada.

Same function as Pointe Mouillee.

Damage by high water, formally very productive passerine and hawk migration point.

A very large and important flyway for passerine birds and hawks.

Source: Scharf, Nesting and Migration Areas of Birds of the U. S. Great Lakes, 1977.

On a national scale, the limits of the breeding ranges of the above listed birds are the wetlands of Michigan. The southern breeding limit of the yellow rail is the Michigan-Ohio state Iine (Sanderson, 1977, p. 68). The northern limit of the black rail and the king rail in North America is approximately a line from Port Huron westward to Muskegon (ibid., pp. 74 and 98). The eastern limit of coot breeding according to Sanderson (ibid., p. 132) is western Lake Erie. The common gallinule's northern boundary breeding limit is the south shore of Lake Superior (ibid., p. 112). Finally, the highest breeding density of the Virginia rail is confined (northern 
and southern boundary) to the lower peninsula of Michigan (ibid., p. 49).

The habitat need for these birds includes wetlands or reasonably wet areas for resting and feeding. Information and specific site inventories are not adequately documented over time to identify high value coastal wetlands. However, since many of these birds are at the limits of their range and need wetlands to perform their normal life functions, based on Larson's criteria, many of the state's coastal wetlands must be considered valuable.

The occurrence of many migratory shorebirds and birds of prey other than those discussed above have been documented in the literature. Tawas Point (Kelley and Kelley, 1973, pp. 111-115) appears to be an important staging area, particularly for passerine birds. Large hawk migrations in fall are well known over western Lake Superior, Tawas Point, Beaver Island, Whitefish Point, Stonington, and the Garden Peninsula (Sheldon, 1965, pp. 79-83). The Erie Marshes are one of the few areas in southern Michigan where large assemblages of shorebirds occur (Butsch, 1954, pp. 46-53). Fifteen species were observed here exclusive of the killdeer and spotted sandpiper which are resident breeders at North Cape. The Woodtick Peninsula and adjacent marshes are important since they provide resting areas for birds migrating along the periphery of western Lake Erie to and from the Little Cedar Point Wildlife Refuge in coastal Ohio (personal communication, Karl Bednarik). Spring migrations of birds of prey including several threatened species such as the Peregrine falcon, osprey, eagle, and double-crested cormorants have been observed at Whitefish Point (Kelley, 1972, pp. 69-75). Yellow-headed blackbirds utilize the Saginaw Bay wetlands especially Tobico, Nayanquing Point and the St. Clair Flats (personal communication, Chuck 
Wolverton and Gerald Martz). Snowy owls winter at Fish Point (personal communication, Gerald Martz).

Species Diversity

A unique value of wetlands is their diversity of aquatic and terrestrial life. An attractive aspect of the Cheboygan Marsh as illustrated by Thobaben (1974a) is that 77 animal species occur in that 96-acre wetland. Bird diversity is as equally varied. Thobaben (1974b, pp. 8-9) recorded 10 nesting species such as the American bittern, coot, black tern and eastern kingbird within that wetland. He also notes that the marsh is used by yellow-headed blackbirds and as a wintering area by snowy owls (ibid., p. 1). In the Magee Marsh some 271 species of birds have been sighted (Bednarik, 1975, p. 16). On Dickinson Island (St. Clair Flats), a party of four observed 43 bird and duck species in two hours (U. S. Army Corps of Engineers, 1974b, p. 126). In St. Johns Marsh DNR wildlife biologists observed 34 species of birds in a single day (DNR, 1976b, p. 4). Included were the threatened marsh hawk and the rare black-crowned night heron as well as six species of herons and bitterns. During spring migration about 50 percent of North America's whistling swan population utilize the southeastern Michigan wetlands (Bellrose, 1976, pp. 95-98), some of which rest and feed in the St. Johns Marsh and presumably the St. Clair Flats to the immediate southeast.

It is clear from such reports that coastal wetlands provide valuable nesting functions as well as cover, food, and migratory resting areas for a diversity of shorebirds, passerines, and birds of prey. Ecologists have suggested that symbiotic relationships exist between bird colonies and wetlands. On the Florida coast, for example, the presence of bird excretions is essential for the rich aquatic plant growth which in turn supports the bird colonies (Wing, 1956, p. 211). Similar important 
relationships have been noted elsewhere. Welty (1975, for example, notes that small marshes may be more important (nests/area) than larger marshes because of the greater edge effect.

Other Fauna

Animals other than waterfowl, furbearers, fish and birds have received less attention in the literature. Notable exceptions include snails and mussels, and a few mammals such as the shrew, lemming and Indiana bat, some of which are endangered, threatened or rare species (Table 50). Also, the occurrence of reptile species have been documented in Table 50. Other common fauna occupying Michigan's coastal wetlands are a variety of snakes and amphibia .

According to Switzenberg (1954, p. 1), Michigan has 17 species and subspecies of snakes most of which are decidedly beneficial since they help control rodents such as rats and mice. Other foods commonly provided in wetlands include crayfish, a variety of insects, fishes, frogs, snails and slugs, as well as toads (ibid., p. 8). Snakes in turn are fed upon by hawks, raccoons and owls. Manville (1952, pp. 13-19) notes that the snakes commonly found in Michigan's wetlands include the hog-nosed snake, green or grass snake, queen snake, Kirtland's snake and the Massasauga rattlesnake.

Ten species of turtles have been identified in the state, nine of which are native (Lagler, 1954, p. 1). These include:

$\begin{array}{ll}\text { Snapping turtle } & \text { Spotted turtle } \\ \text { Soft-shell turtle } & \text { Wood turtle } \\ \text { Box turtle } & \text { Map turtle } \\ \text { Blandings turtle } & \text { Musk turtle } \\ \text { Painted turtle } & \text { Slider turtle }\end{array}$

Turtles are beneficial in that most of them act as scavengers in keeping the waters free of dead fish and animals. 
Lagler (ibid., p. 3) notes some turtles feed on mosquito pupae, on insects which prey on fish, and on mollusks which harbor fish parasites during certain stages of their life cycle. Snapping turtles are trapped and sold for human consumption. At Fish Point a trapper took over 100 twenty-pound snapping turtles in the summer of 1977 which were valued at $\$ 2.00$ per pound.

These and other fauna enhance the diversity of wetland wildlife and they fill an ecological niche as well. As noted in Saginaw Bay, a variety of reptiles and amphibians occur (U. S. Department of Interior, 1970b, p. 291). Included are:

$\frac{\text { Reptiles }}{\text { Snapping Turtle }}$
Painted Turtle
Blandings Turtle
Softshell Turtle
Red Bellied Snake
Brown Snake
Water Snake
Garter Snake
Hognose Snake
Ringneck Snake
Green Snake
Blue Racer
Rat Snake

Amphibia

American Toad

Spring Peeper

Tree Frog

Cricket Frog

Pickerel Frog

Chorus Frog

Leopard Frog

Green Frog

Wood Frog

Bull Frog

Mud Puppy

Blue-spotted Salamander

Spotted Salamander

Red-backed Salamander

There is little precise data on the abundance and occurrence of reptiles and amphibia with regard to Michigan's coastal wetlands. Nevertheless, these fauna are significant to the food webs which support the more economically important fish and game species.

Wetland Use by Nature Groups

Data on coastal wetland use by nature groups such as the Michigan Audubon Society are not routinely collected. 
A questionnaire was designed and sent to the 39 chapters of the Society asking each chapter to document which wetlands were visited, the number of people in each group and the purpose of the visit. Fourteen chapters (36\%) responded to this inquiry. Table 55 represents the response of those groups. The data included for Fish Point, also includes group visits and vehicle counts made by the Michigan DNR at Fish Point in 1977.

As noted in Table 55, a variety of non-consumptive activities occur in the coastal sites to include not only birdwatching, but research, photography and botanical study as well. Based on the limited response, Fish Point, Waugoshance Point, Cheboygan, and the wetlands of Lake St. Clair are popular nature study areas. It must be noted that the data represent minimal wetland use essentially by one organization. Field trips by individuals, other organized groups or educational institutions would reflect greater use than what is presented on Table 55. VALUES OF COASTAL WETLANDS FOR NONCONSUMPTIVE RECREATION USES

Other nonconsumptive uses of wildlife in Michigan are presently considered to be at least equal in man days to consumptive uses. The latter, however, is projected to increase at a faster rate than hunting uses. Currently, Michigan has 284,200 acres of public hunting areas, and on1y 128,200 acres of state parks and recreation areas which provide for recreation other than hunting and trapping (Great Lakes Basin Comm., 1975c, p. 27 and 28). Yet, future projections reveal that nonconsumptive uses of wildlife and wildlife lands will increase more rapidly than hunting use and will compensate for decreases in consumptive uses wherever they occur (ibid., p. 73). These nonconsumptive uses are:

Nature and ecology trails. Interpretative and photography centers. 


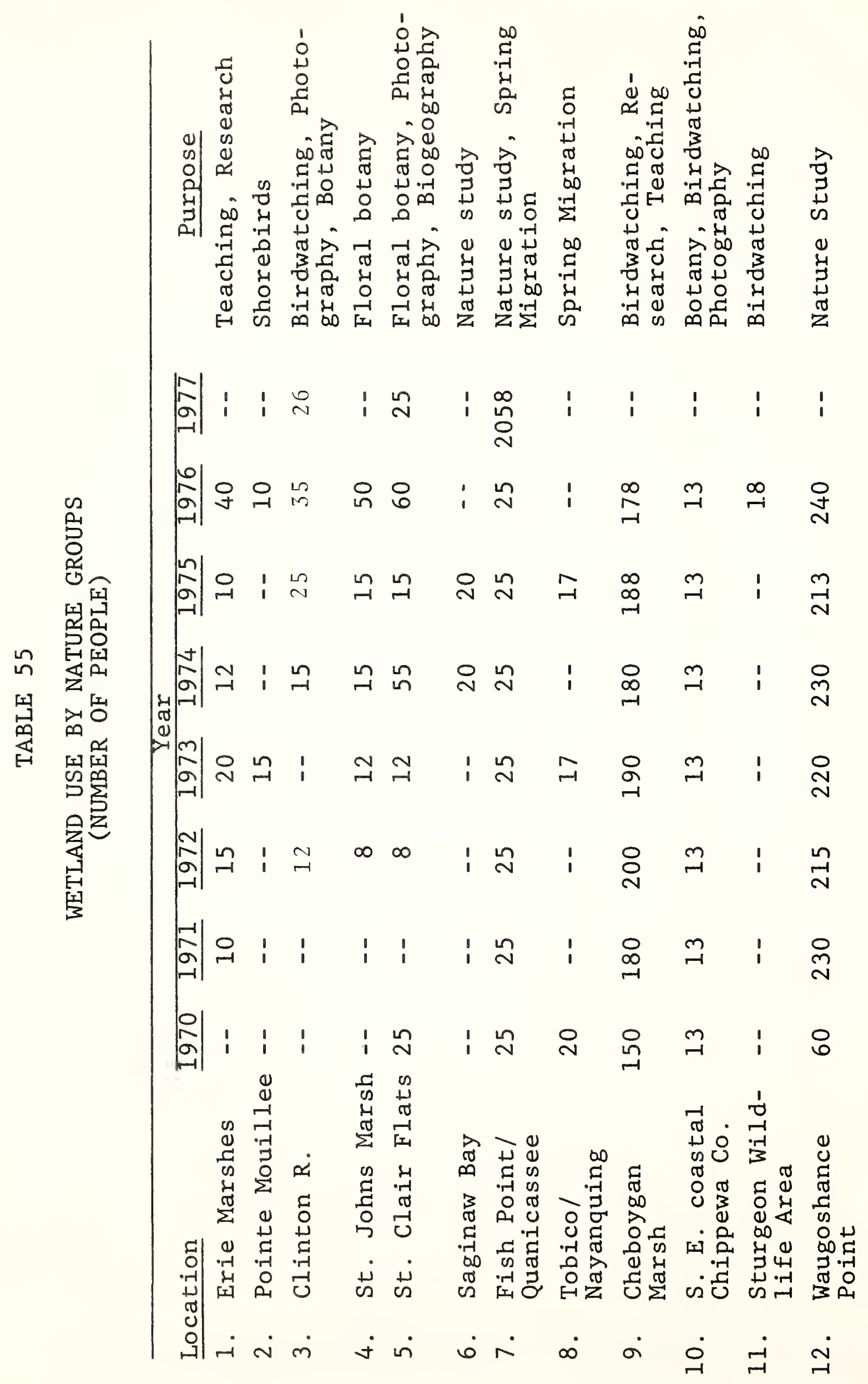



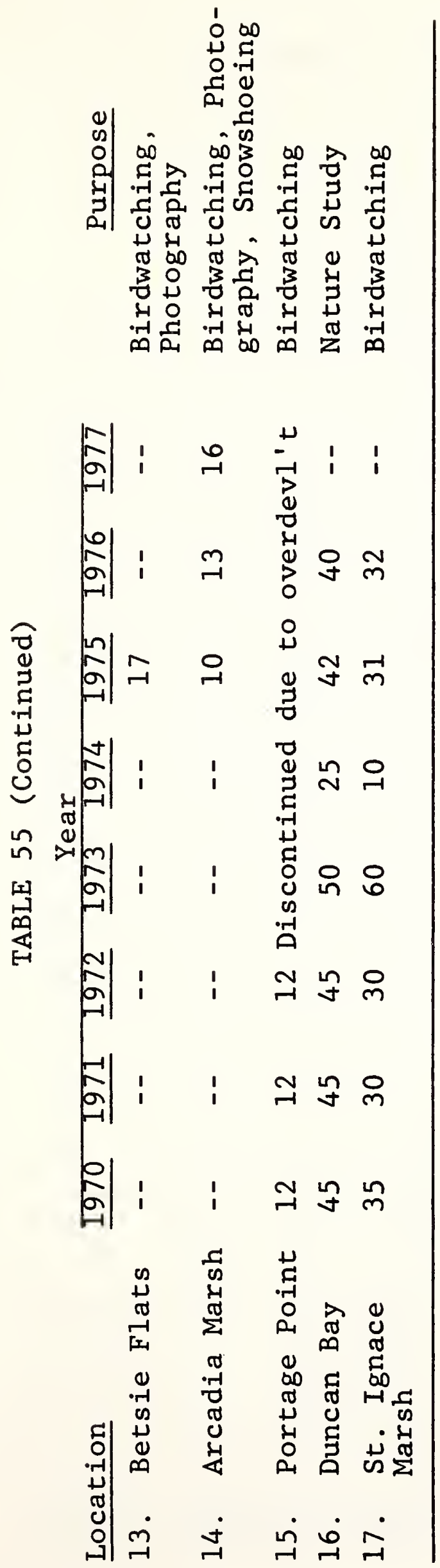
State game area visitor stations.

Scientific and educational study areas.

Migration stopover viewing sites.

Wildlife wintering and feeding stations.

Non-adult sport fishing areas.

Nonconsumptive use of Michigan's coastal wetlands has not been studied. A survey of public use of southern Michigan game and recreation areas, however, does provide some pertinent data. Based on a postcard questionnaire, the survey of 15 waterfowl game areas revealed that nonhunting use exceeded the consumptive use (Table 56).

Although an inland waterfowl game area, the Shiawassee River State Game Area, was a major unit in the study, the sample also included the following coastal wetlands:

Erie State Game Area

Fish Point Wildlife Area

Nayanquing Point Wildlife Area

Pointe Mouillee State Game Area

Quanicassee Wildiife Area

St. Clair Flats Wildlife Area

Tobico Marsh State Game Area

Wigwam Bay Wildlife Area

Wildfowl Bay Wildlife Area

TABLE 56

NON-HUNTING VS. HUNTING USE OF PUBLIC WATERFOWL GAME AREAS

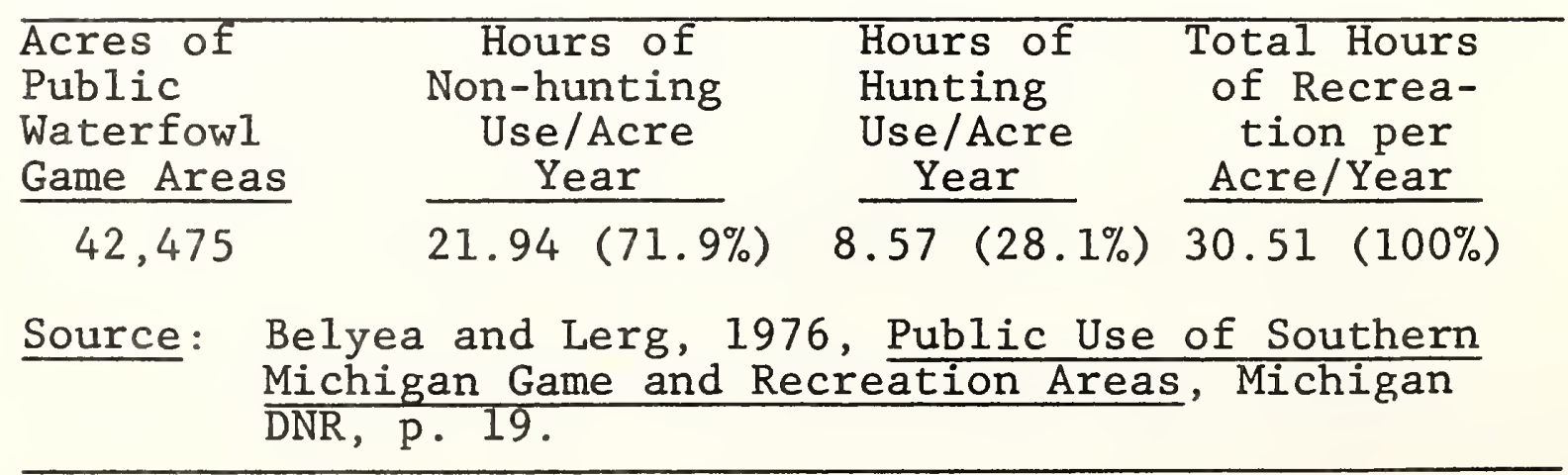


The sample design regarding the data in Table 56 does not allow generalization about specific wetlands. The main use of these waterfowl areas is as follows: fishing $(57.1 \%)$, waterfowl hunting (23.9\%), camping $(2.6 \%)$, and all other uses (16.4\%) (Belyea and Lerg, 1976, p. 34). Based on a "1976 Statewide Telephone Survey" the Michigan DNR tabulated nonconsumptive recreational use in the state's game and wildlife areas (personal communication, Daniel Kitchel). Several coastal game and wildlife areas have a large proportion of wetland (e.g., Erie, St. Clair Flats, Wildfowl Bay, Tobico, Pentwater and Betsie River). It has been estimated that 580,000 participations occurred in non-hunting and non-fishing activities by Michigan residents while visiting 15 coastal state game and wildlife areas in 1976. The 15 state game and wildlife areas included:

$\begin{array}{ll}\text { Betsie River } & \text { Pointe Mouillee } \\ \text { Erie } & \text { Tobico } \\ \text { Manistee River } & \text { Fish Point } \\ \text { Muskegon } & \text { Nayanquing Point } \\ \text { Pentwater } & \text { Quanicassee } \\ \text { Petobego } & \text { St. Clair Flats } \\ \text { Wigwam Bay } & \text { Wildfowl Bay } \\ \text { Beaver Island } & \end{array}$

The acreage of the above coastal state game and wildlife areas totals 97,000 acres. Nonconsumptive activities in these areas include sightseeing, boating, hiking, picnicking, snowmobiling and nature study.

Data derived from a national survey suggests that dollars spent per participant is significant to the value of coastal wetlands. As determined by Payne and DeGraaf (1975, pp. 6-10), the direct expenditures attributable to the enjoyment of nongame birds in 1975 was 1.7 times the amount spent by waterfowl hunters exclusive of indirect expenditures for transportation, lodging and food. As 
determined by the 1970 National Survey of Fishing and Hunting (U.S. Dept. of Int., 1972, p. 11), the average annual expenditure of a waterfowl hunter was $\$ 84.47$. If the cost-ofliving factor of 1.542 for interpolating from 1970 to 1977 is multiplied by $\$ 84.47$, the updated value is $\$ 130.25 /$ hunter/ year. If food, transportation and lodging costs are substracted as indirect costs from the $\$ 130.25$ average annual waterfowl hunter's expenditures $(\$ 130.25-\$ 29.53=\$ 100.72)$, and the remaining direct costs are multiplied by 1.7 ( $\$ 100.72$ $x 1.7=\$ 171.23$ ), then the average annual participant expenditure by nonconsumptive recreationalists would amount to $\$ 200.76(\$ 171.23+\$ 29.53)$. Proportionally, the value of a nonconsumptive recreation day, compared to a waterfow 1 hunting day of $\$ 15.00$ would be $\$ 23.12$. Assuming that 580,000 recreation days or trips were involved in the 15 coastal state game and wildife areas, then these public coastal environments generate a total annual value of $\$ 13,409,600(580,000 \times \$ 23.12)$. Given 97,000 acres of wet1 ands and associated upland environments in these coastal game and wildife areas, the annual economic value per acre is $\$ 138.24$ ( $\$ 13,409,600$ divided by 97,000 acres). Potentially, Michigan's 105,855 acres of coastal wetlands may have an average annual nonconsumptive recreation value of $\$ 128.24$ / wet 1 and acre.

Not only are expenditures for nongame bird enjoyment high, but they have been increasing rapidly in the past several years. For example, gift bird book sales in the U.S. rose from $\$ 1.5$ million in 1970 to $\$ 3.1$ million in 1974 (U.S. Department of Agriculture, 1977, p. 85). Dues paid to the National Audubon Society doubled in five years, increasing from $\$ 1.6$ million in 1970 to $\$ 3.1$ million in 1974 (ibid., p. 85). Other evidence of interest in the nonconsumptive appreciation of wildlife is suggested by growth in subscriptions to National Wildlife magazine from 60,000 in 1963 to 350,000 by 1975 (ibid., p. 85). These indicators suggest that the future value of the state's nonconsumptive recreational resource will increase. 
Locally, some preliminary data regarding nonhunting uses are available for the St. Clair Flats Wildlife Area, specifically Lower Harsens Island (Table 57). Sport fishing in summer, particularly bank fishing along the main channels and canals, accounts for the heaviest use of this wetland (Pospichal, undated, p. 8). Wildlife and flora viewing from canoes and non-motorized boats is spectacular on Harsens Island, as well as on nearby Dickinson Island, because canals and abandoned river channels allow access to most interior areas. Based on the data in Table 57, nonconsumptive use of this coastal wetland provides 41.92 man days of recreation per acre/ year. In comparison, waterfowl hunting which traditionally was the main recreational use, amounted to only 2.73 recreation days per wetland acre/year.

\section{TABLE 57}

NON-HUNTING AND HUNTING USE OF ST. CLAIR FLATS WILDLIFE AREA PRELIMINARY DATA FOR LOWER HARSENS ISLAND

\begin{tabular}{lrc}
\hline Non-Hunting Uses & $\begin{array}{c}\text { Estimated } \\
\text { Man Days }\end{array}$ & $\begin{array}{c}\text { Man Days } \\
\text { Acre/Year }\end{array}$ \\
\cline { 2 - 2 } Sport Fishing & 100,000 & 38.46 \\
Bow and Arrow Carp Fishing & $3-5,000$ & 1.54 \\
Bird Watching & 3,000 & 1.15 \\
Canoeing and Boating & $\frac{2,000}{109,000}$ & $\frac{0.77}{41.92}$ \\
$\quad$ SUBTOTAL & 7,108 & 2.73 \\
Hunting Uses & Waterfow1 Hunting & \\
Source: Pospichal, Undated, Preliminary Management Plan \\
\hline
\end{tabular}

Coastal wetlands are important viewing areas for several reasons. As discussed earlier, many of the coastal wetlands function as concentration areas for migration of waterfowl, shorebirds, passerines, and birds of prey. Point Pelee, Ontario, is internationally renowned as a fall migratory viewing area for not only 
waterfowl, but also Monarch butterflies, songbirds and shorebirds. Moreover, several coastal counties in Michigan, including Berrien, Cheboygan, Emmet, Isle Royale, Keweenaw, Monroe, and Wayne Counties, have large numbers of rare or threatened species (Beaman, 1977, p. 111). Three endangered and 79 threatened plants are located within aquatic and wetland environments of Michigan (Table 52). With regard to birds, Cheboygan Marsh, for example, provides habitat for the marsh hawk and the American bittern, a threatened and rare species, respectively (Thobaben, 1974b, p. 8).

The nature of the wetland influences the scenic quality of the site. Dense, monotypic marshes exhibit low species diversity and species abundance which, in turn, reduces the birdwatching quality. A wetland exhibiting half vegetation cover and half open water provides the most suitable habitat for aquatic species (Weller and Spatcher, 1965, p. 28). The Great Lakes coastal wetlands, because of lake level fluctuations, are not as stable as inland wetlands (Woodby, 1974, p. 12). Hence, stands of cattails and other monotypic communities, which can lead to senescence and low productivity, are constantly being disrupted by water level changes. Moreover, if the wetland contains a composite of environments or a strong environmental gradient, as on Dickinson Island of the St. Clair Flats, then the species diversity is further enhanced. At Cheboygan Marsh, 43 different wildlife species were observed in the cattail marsh, whereas 29 species were found only in the sedge-willow ecotone which provides dry marsh and upland habitat (Thobaben, 1974b, p. 9). At Magee Marsh, a vastal wetland in northern Ohio, a total of 271 wildlife species have been recorded (Bednarik et al., 1975, p. 9).

Visitor and interpretive centers at state game areas can provide for the multiple use uf waterfowl and other game resources. The visitor center at Magee Marsh Wildlife Area Headquarters attracts 50,000 visitors each year (Bednarik, 1975, Table 2). This quality non- 
consumptive use has increased 300 percent during the past few years since the station was established. At present, Michigan has a few visitor's centers within coastal

wildlife areas. An interpretive center has been ronstructed at Tobico and one is being considered for Pointe Mouillee State Game Area, but the latter facility is still in the planning stages. Visitor centers at inland state game areas, e.g., Shiawassee Wildlife Refuge Area, have been successfully attracting viewers for many years.

Urban fishing and non-motorized boating are two activities currently underdeveloped in coastal wetlands. As wetlands near metropolitan areas are degraded by poor water quality or fragmented into small parcels by development (Great Lakes Basin Comm., 1976, pp. 3-5), their use by turbidity-intolerant fish and easily-disturbed wildlife diminishes. Nevertheless, these small parcels of somewhat degraded wetlands can provide selected nonconsumptive uses. For example, the fishing of carp, bullheads, and other wetland species can give angling opportunities to many urban youth (Fogle, 1975). Also, while quietly canoeing or paddling a boat through wetland environments, particularly at dusk or dawn, the visitor observes a variety of wildlife not usually seen on foot. Such boat trips are a common visitor's experience of the Florida Everglades.

The St. Clair River delta, including its wetland complex, has high scientific value because this delta is one of the relatively few large fresh-water deltas in the world and is geologically and biologically well known. In addition, because of tremendous waterfowl use of Wildfowl Bay and Fish Point during migration and the high duck nesting densities at Portage Marsh, these wetland areas are of special scientific interest.

The demand for nonconsumptive recreation has been projected for six planning subbasins in Michigan by 
the Great Lakes Basin Commission. By the year 2020, the demand will greatly exceed the supply, especially in southeastern Michigan and the Saginaw Bay region (Table 58). The situation is critical because the participation demand for consumptive and nonconsumptive use of wildlife is expected to double the current demand by 2020 A. D., while the available habitat continues to be degraded and/or lost to development (Great Lakes Basin Comm., 1975c, p. 123).

TABLE 58

UNSATISFIED PARTICIPATION IN NONCONSUMPTIVE USE OF WILDLIFE HABITAT BY PLANNING SUBBASIN IN MICHIGAN, FOR SELECTED YEARS, IN $1000^{\prime} \mathrm{S}$ OF MAN DAYS

\begin{tabular}{|c|c|c|c|}
\hline Planning Subbasin & $\begin{array}{l}\text { Man Days } \\
1980 \\
\end{array}$ & $\begin{array}{l}\text { Man Days } \\
2000 \\
\end{array}$ & $\begin{array}{l}\text { Man Days } \\
2020 \\
\end{array}$ \\
\hline $\begin{array}{l}\text { Northern Half of Upper } \\
\text { Peninsula }\end{array}$ & 15.0 & 7.2 & 27.9 \\
\hline $\begin{array}{l}\text { Lower Half of U. P. and } \\
\text { Northwest part of the } \\
\text { Lower Peninsula }\end{array}$ & 202.3 & 332.4 & 514.7 \\
\hline $\begin{array}{l}\text { Northeast portion of } \\
\text { Lower Peninsula }\end{array}$ & 16.1 & 66.5 & 132.1 \\
\hline $\begin{array}{l}\text { Saginaw Bay and Northern } \\
\text { Part of the Thumb Area }\end{array}$ & 396.6 & 786.3 & $1,203.7$ \\
\hline $\begin{array}{l}\text { Southwest portion of } \\
\text { Southern Michigan }\end{array}$ & 504.5 & 753.6 & 966.4 \\
\hline $\begin{array}{l}\text { Southeast portion of } \\
\text { Michigan }\end{array}$ & $1,596.4$ & $2,474.2$ & $3,539.0$ \\
\hline Great Lakes Basin & Comm., 197 & a, p. 99. & \\
\hline
\end{tabular}

Summary of Nonconsumptive Recreational Use Waterfowl hunting, trapping and fishing are primary, direct revenue producers for the state. In terms of hours of use, non-hunting activities greatly exceed hunting activities ( 41.92 man days vs. 2.73 man days). Although the data cannot be accurately related to a 
dollar value at this time, some preliminary estimates suggest that coastal wetlands have a nonconsumptive recreational value of $\$ 138.24$ acre/year.

As noted in Chapter 2, coastal wetlands are being 1ost. This chapter indicates future demand for nonconsumptive uses are increasing and will double by the year 2020. These two facts clearly reveal that the demand for wetland use will increase as the wetland acreage decreases. EFFORTS TO PROTECT UNIQUE COASTAL SITES FOR NONCONSUMPTIVE USES

To meet future demands for nonconsumptive use, the Michigan DNR is making an effort to preserve and enhance natural areas throughout the state (personal communication, Paul Rasmussen). The sites being considered include natural areas of biological and scenic interest, and areas of geologic uniqueness (i.e., type localities). The coastal areas under consideration are presented in Table 59. Of the 20 sites under consideration, at least 10 sites involve wetland localities.

The proposed coastal sites have been mapped (Figure 25). The data compiled throughout this report concur with many of the proposed selections of coastal areas identified by the DNR. Pointe Mouillee is well known for its waterfowl habitat and documented threatened species. The Tobico Marsh, an exceptional wetland, particularly with regard to aquatic fauna and migratory waterfowl, is now a National Landmark (Goodwin and Niering, 1975, pp. 230 and 240). As noted by Scharf (1977), Sleeping Bear Dunes, Tawas Point, Tobico, Pointe Mouillee, and Sterling State Park are important nesting and migration areas for shorebirds. 


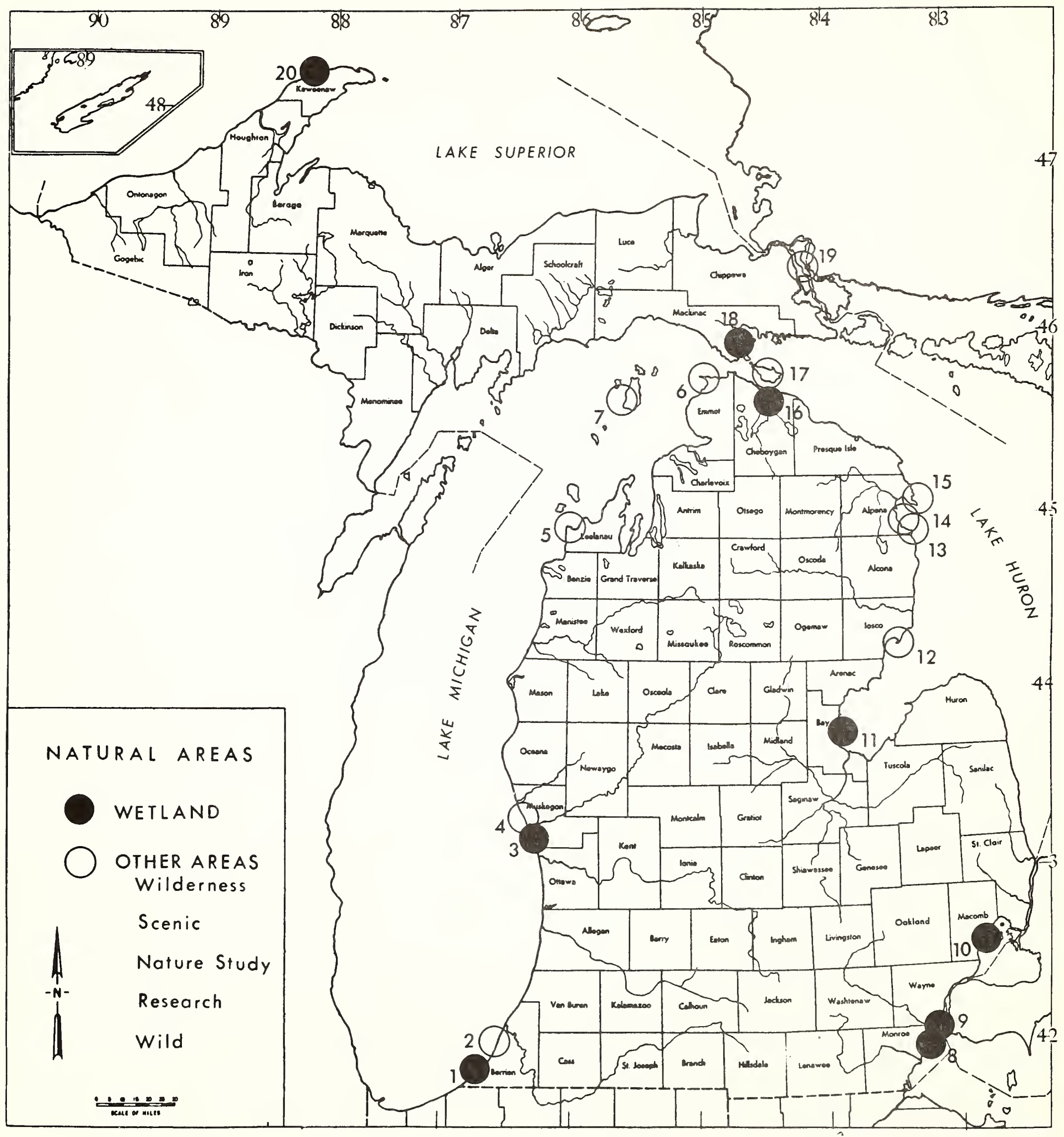

FIGURE 25--Proposed Natural Areas in Coastal Michigan. See Table 59 for locations and source. 
TABLE 59

PROPOSED NATURAL COASTAL AREAS UNDER CONSIDERATION BY THE DNR

Area

1. Galien River

2. Warren Dunes State Park

3. Hoffmaster State Park

4. Muskegon State Park

5. Sleeping Bear Dunes

6. Wilderness State Park

7. Beaver Island Complex

8. Pointe Mouillee State Game Area

9. Sterling State Park

10. Metropolitan Beach

11. Tobico Marsh

12. Tawas Point

13. Gull Island

14. Scarecrow Island

15. Negwegon State Park and Thunder Bay River State Park

16. Duck Marsh

17. Bois Blanc

18. Straits Bay

19. Neebish/Sugar Island Complex

20. Eagle Harbor
Use or Interest

Wetlands

Ancient dunes, Virgin woods

Lakeshore, Dunes, Wetlands

Lakeshore, Dunes

Wilderness area

Research/Natural area

Wilderness area

Wetlands

Wetlands and Hibiscus

Wetlands

Wetlands

Geological spit

Wilderness area

Wilderness area

Wild area

Wet 1 and

Research/Nature study

Wet 1 and and Waterfow1

Wilderness area

Wet 1 and

Source: Natural Areas Coordinator, Paul Rasmussen, Land Resources Division, Dept. of Natural Resources, Lansing, MI . 


\section{CHAPTER SEVEN}

FISH AND WILDLIFE PRODUCTIVITY BY GEOGRAPHIC REGION

The productivity of fish and wildlife as related to coastal wetlands may be presented in two ways: (1) as wildlife and fish produced/area/year; and (2) as economic benefits of wildlife and fish use/area/year. If the production of fish and wildlife per wetland acre is known, a potential average fish and wildlife production per year may be determined by geographical area. As noted in Table 60 , production has been calculated for ducks, muskrats, raccoons and commercial fish based on estimated densities of fish and wildlife determined in preceding chapters. The densities are:

\section{Ducks}

Muskrats

Raccoons

Commercial Fish
0.31 flying ducklings/wetland acre/year

3.0 animals harvested/wetland acre/year

0.11 animals harvested/wetland acre/year

17.1 lbs 1 anded/wetland acre/year

It must be recognized that the table is theoretical in that the total production derived is largely dependent upon the area of existing wetlands in the given geographical regions. Thus, a lakeshore with extensive wetland acreage, according to this procedure, will exhibit high fjsh and wildlife production. More detail and a more accurate geographical perspective have been presented in the preceding chapters. As discussed, most fish and wildlife are concentrated in certain coastal wetland areas. The data in Table 60 assume uniform fish and wildlife population density which, in turn, suggests uniform environmental and habitat conditions as well as uniform management procedures.

Based on Table 60 and the data analyzed and discussed in Chapter 3 , the coastal wetlands produce large numbers of dabbling ducks and coots. Although St. Marys River and the Detroit River are less productive than other coastal wetlands, overall the coastal wetlands are more productive than the inland wetlands. At present, the coastal wetlands comprise 3.3 percent of the state's 
total wetland acreage, but account for 14 percent of Michigan's annual duck production.

TABLE 60

POTENTIAL AVERAGE ANNUAL COASTAL FISH AND WILDLIFE PRODUCTION*

\begin{tabular}{|c|c|c|c|c|c|}
\hline \multirow{2}{*}{$\begin{array}{l}\text { Geographical } \\
\text { Area }\end{array}$} & \multirow[b]{2}{*}{ Acres } & \multirow[b]{2}{*}{ Ducks } & \multicolumn{2}{|c|}{ Furbearers } & \multirow{2}{*}{$\begin{array}{c}\text { Commercial } \\
\text { Fish } \\
\end{array}$} \\
\hline & & & Muskrats & Raccoons & \\
\hline Lake Superior & 1,200 & 372 & 3,600 & 132 & 20,520 \\
\hline St. Marys River & 11,978 & 3,713 & 35,934 & 1,318 & 204,824 \\
\hline Lake Michigan & 29,846 & 9,252 & 89,538 & 3,283 & 510,367 \\
\hline Lake Huron & 5,686 & 1,763 & 17,058 & 626 & 97,231 \\
\hline Saginaw Bay & 33,380 & 10,348 & 100,140 & 3,672 & 570,798 \\
\hline $\begin{array}{l}\text { L. St. Clair and } \\
\text { St. Clair River }\end{array}$ & 15,630 & 4,845 & 46,890 & 1,719 & 267,273 \\
\hline Detroit River & 1,420 & 440 & 4,260 & 156 & 24,282 \\
\hline $\begin{array}{l}\text { Lake Erie } \\
\text { TOTALS }\end{array}$ & $\frac{6,715}{105,855}$ & $\frac{2,082}{32,815}$ & $\frac{20,145}{317,565}$ & $\frac{739}{11,645}$ & $\frac{114,827}{1,810,122}$ \\
\hline
\end{tabular}

*Wildlife data in numbers of animals. Fish data in pounds.

As indicated in Chapter 4, muskrat and raccoon harvest increases from north to south. This is to be expected in the case of muskrats since the total Upper Peninsula cattail acreage totals only 3,603 acres whereas in the Lower Peninsula, cattails account for 27,206 acres. Cattails are the primary food source for the muskrat, however, as noted in the literature, other foods include bulrushes, pickerel weed, and sedges (Bellrose, 1950, p. 314). Since other marsh vegetation is consumed by muskrats, the total wetland acreage is used to determine muskrat production in the state's coastal wetlands rather than just the cattail acreage. The data consistently reveal that the Saginaw Bay area as well as St. Clair, Wayne, and Monroe Counties are the highest annual furproducing areas. Although the harvests in Arcadia Marsh, Munuscong Bay and Little Bay de Noc are high compared to other 
regions, in general, the coastal wetlands of Lake Michigan and the St. Marys River are not high-yield areas for fur.

The production of commercial fish suggests that Lake Michigan can support a significant commercial fishery in the coastal wetlands. However, because yellow perch fishing is closed and other warmwater coastal species are insufficient in numbers, the commercial fishing in Lake Michigan is less important than the table indicates. The most accurate correlation between the table and the actual commercial fishing activities is in Saginaw Bay. In the St. Marys River, with the exception of suckers and yellow perch, most available species are designated as sport or coldwater, non-coastal fishes. Lake St. Clair has been closed to commercial fishing since the 1930's, and no commercial fishing now regularly occurs in the Detroit River. With regard to sport fish $\perp t$ is difficult to separate the coastal wetland-related catch from the inland warmwater catch. Therefore, sport fishing was not included in Table 60. As noted in Chapter 5, 48 percent of the state's total coastal fishing effort is in Lake St. Clair. This lake accounts for 32 percent of the state's coastal catch. Therefore, Lake St. Clair must be regarded as having the highest sport fish production. Conversely, Lake Superior and Lake Huron excluding Saginaw Bay, are less productive because of the lack of extensive coastal wetlands and the remoteness from large urban centers. In contrast, coastal Lake Erie no longer supports a productive sport fishery because of wetland loss and habitat degradation, especially with regard to high-value species such as northern pike, yellow perch and smallmouth bass.

A second way of viewing wetland productivity is to examine economic benefits with regard to a dollar value for each geographical area. Table 61 illustrates the potential economic benefits of coastal fish and wildife and nonconsumptive values per year. The dollar value per acre of waterfowl, fur (muskrats and raccoons), commercial and sport fish, and nonconsumptive recreation is as follows: 


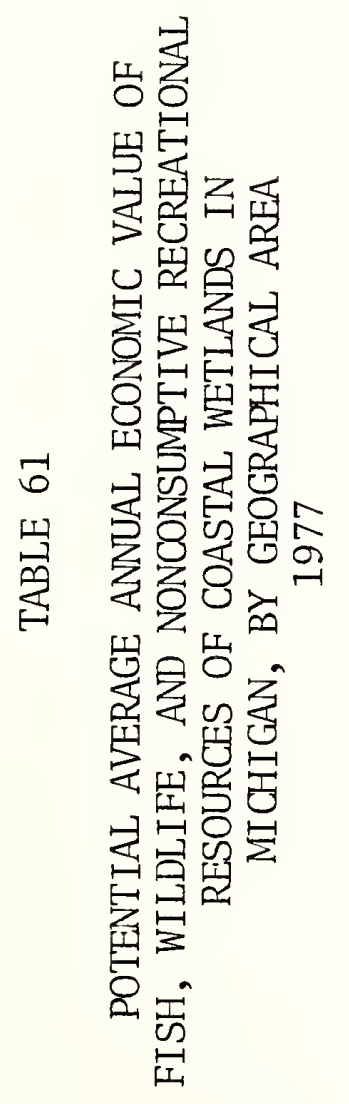

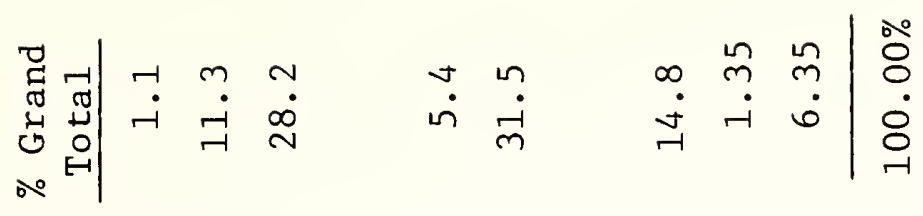

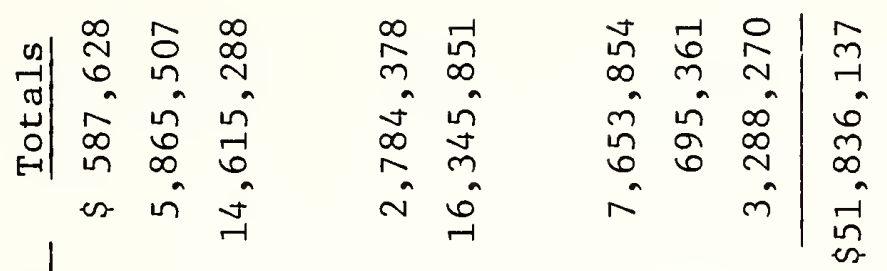

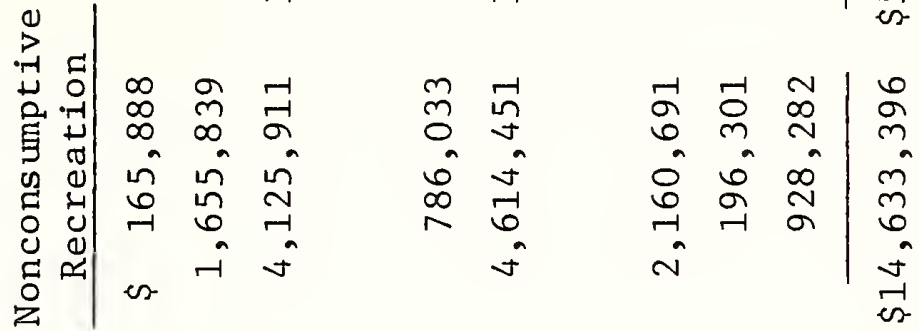

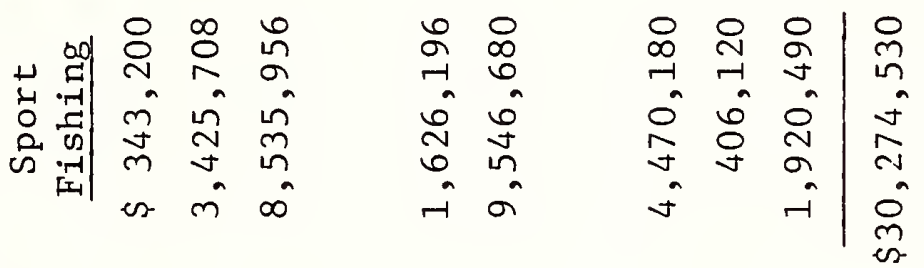

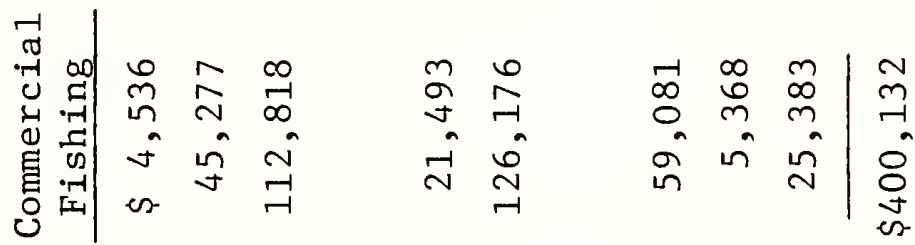

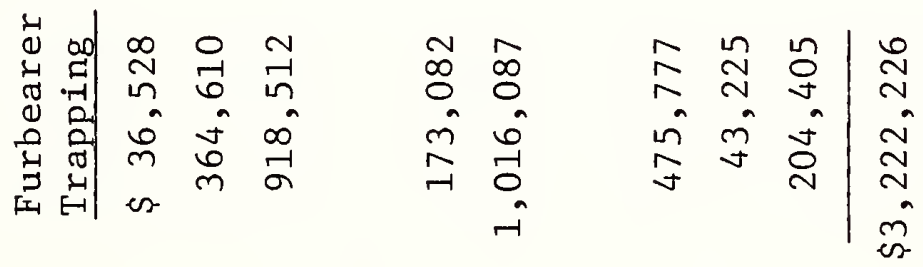

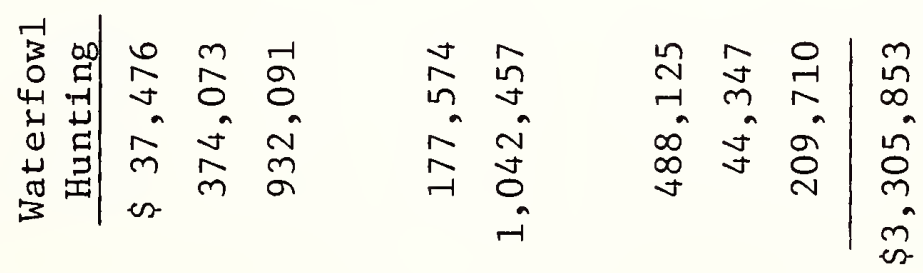

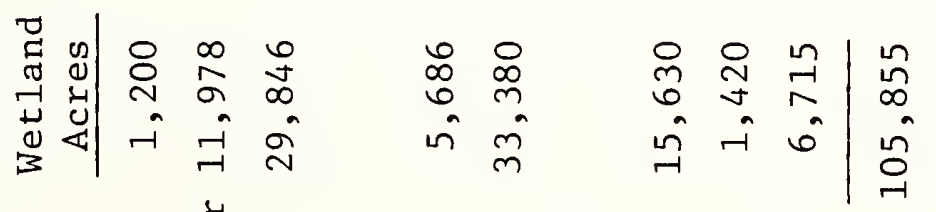

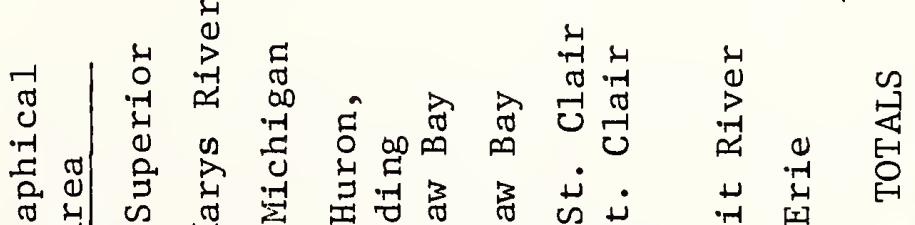

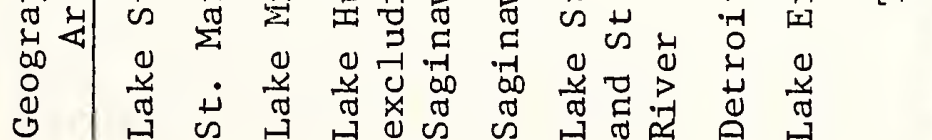


Waterfowl Hunting Furbearer Trapping Commercial Fishing Sport Fishing Nonconsumptive Recreation
$\$ 31.23 /$ wetland acre/year $\$ 30.44 /$ wetland acre/year $\$ 3.78 /$ wetland acre/year $\$ 286.00 /$ wetland acre/year $\$ 138.24 /$ wetland acre/year

As in Table 60, it must be recognized that Table 61 is a very broad overview and the variation in habitat, environment, and policies are assumed to be uniform from one wetland to the next across the state. Also, the economic benefits are area dependent. Thus, many comments expressed about the preceding table are applicable to Table 61 as well. For a more accurate geographical presentation, it is recommended that the preceding chapters be consulted.

The potential economic benefit of the coastal wetlands, in terms of fish, wildlife, and nonconsumptive recreational resources, is $\$ 51.8$ million per year (Table 61). Given 105,855 acres of coastal wetland, this amounts to $\$ 489.69 /$ wetland/acre/year. Because the average annual gross return is largely a function of wetland acreage, Saginaw Bay with 33,380 acres is potentially the most significant geographical area of the Great Lakes. Although Lake Michigan aerially, and hence in terms of economic benefits is second, significant problems do occur, in part because of the lack of commercial fishing already discussed. In contrast, since 48 percent of the state's coastal sport fishing and 32 percent of the state's coastal fish catch is from Lake St. Clair, the actual economic benefit of the St. Clair wetlands is greatest and Saginaw Bay is probably second. Both areas are adjacent to large urban areas and as indicated in the text, these wetlands have the highest latent demand for fishing, duck hunting and nonconsumptive uses as well. Moreover, both areas exhibit forecasted habitat deficiency for migratory waterfowl. Based on proximity, the Lake Erie and Detroit River wetlands should exhibit high economic values, but conversions to other land uses and environmental degradation have resulted in lower economic values. 
MATRIX OF COASTAL WETLAND VALUES

Table 62 is a composite of referenced values in the text with respect to geographical location. Where possible, the wetlands have been subdivided into individual natural geographic units. For example, the Les Cheneaux area is subdivided into seven wetland units. An additional unit, "Les Cheneaux," has been added here because some references are not specific enough to pinpoint a particular wetland within that island complex.

In any evaluation such as this, it is just as important to indicate what literature is available in terms of specific wildlife, fish and nonconsumptive values as well as what information is lacking. It is important to note that some wetlands are considered to be of high value because their values have been well documented. However, this does not mean to say that if little or no documentation exists for a given wetland, that the wetland is of no value.

Based on the matrix, most coastal wetlands in the state have some documented fish or wildife value. Available literature for waterfowl migration and breeding, endangered, threatened and rare species, and avifauna is reasonably complete. With regard to these categories, studies in the Upper Peninsula and in coastal Lake Michigan appear to be fewer than in the eastern part of the state. Goose Island, in Mackinac County, has not been adequately inventoried. Similarly, the wetlands on East Sugar Island, Duck Lake, and Colton, Back, Maxton and Fowler's Bays in Chippewa County require more information. In the Lower Peninsula, Allegan and Van Buren Counties stand out as inadequately inventoried areas for fish and wildlife. Inventories such as those of Thobaben (1974a and $b$ ) and Woodby (1974) would be most useful since their objective was to rapidly and inexpensively document fish and wildlife values in a given wetland. As noted in 
Chapter 2, wetland losses are not solely confined to southeastern Michigan, but have occurred statewide to include the less accessible areas of the state. Therefore, the more remote areas require investigation as well.

In general, fish and fur values, with few exceptions, are not well inventoried in Michigan. To our knowledge, the regional distribution of fur areas, other than those of southeastern Michigan (e.g., Pointe Mouillee) has not been updated since the 1940 's. The DNR policy to inventory fish and wildlife by region discourages or prohibits a wetland by wetland assessment for fur.

The coastal wetlands have been ignored with regard to commercial and sport fish. Most investigations have been concentrated in deeper off-shore areas or up streams and rivers. Even in southeastern Michigan where wildlife values are generally well documented, the regional values of fish require more investigation.

Overview of Wetland Values

Because few economic value assessments of wetlands have been undertaken, it is difficult to compare our results to those of other studies. Nonetheless, our estimate appears to be within the range of other research. Benson and Perry (1965) reported that an average acre of marsh in New York state had an annual net value of $\$ 20$ per acre. However, if gross economic values are employed, as in the case of this study, an average annual value of $\$ 400$ is obtained (as the net value was 0.05 of the gross). Moreover, if the 1965 value is inflated to 1977 values using a costof-living factor of 1.95 , then an average annual value of $\$ 780$ per marsh acre is attained. An earlier study by Anderson (1960) indicated that the combined value of tourism, sporting activities and fisheries was worth $\$ 167$ per acre annually for the bays in the Corpus Christi area. If these 1960 values are converted to 1977 values by employing a cost-of-1iving factors of 2.06, then a comparable 1977 value of $\$ 344$ per acre is obtained. In contrast, Gosselink, 
Odum and Pope (1973) reported an annual return per acre of only $\$ 100$ for sport and commercial fishing in a typical marine marsh-estuary system. Even with inflation, that value is much less than the usually high values reported for marine estuaries.

Wetlands have economic values in addition to those investigated in this study. Because wetlands receive drainage from upland environments, they may act as filters, thus reducing sedimentation and turbidity in rivers, lakes and other water bodies. Other economic values indicate surface water storage, groundwater recharge, and water quality improvement through nutrient uptake by wetlands plants. When used as a waste treatment system, wetlands may provide over $\$ 3,500$ per acre annually, especially with regard to tertiary treatment (Sullivan, 1976). Considerable research is currently being conducted on the use of wetlands for areawide water quality management as we11 as for treatment of sewage effluents (Ti1ton, 1976). In short, each wetland is unique, thus the ecological functions and economic values should be evaluated on an individual basis, perhaps by employing the criteria estabished by Larson (1976).

The average economic values derived in this study vary greatly from one geographic area to another. Depending on the wetland characteristics, and proximity and accessibility to potential users, a particular wetland system may exhibit a range of potential values. It must be emphasized that economic evaluations based on average values per acre suggest that larger wetlands are more valuable than smaller wetlands. Furthermore, most of the annual economic return values in this investigation are public values as opposed to an average income a private landowner might expect from his property. Thus, provided the public has access to the wetlands and multiple use is made of the available resources, wetlands may generate several hundred dollars worth of gross annual return per acre.

Our map survey has revealed that Michigan has lost approximately 70 percent of its coastal wetland resource base since settlement by European settlers. With regard to 
the future, projections indicate that up to 20 percent of the existing 105,855 acres may be impacted by private interests within the next decade. This projected coastal wetland loss should be carefully evaluated in terms of previous wetland losses, loss of revenue provided by the wetland resources, and by the fact that unsatisfied participant demand for waterfowl hunting and sport fishing already exists in many coastal counties. This unsatisfied or latent participation demand for recreation appears particularly acute in populous southeastern Michigan. Waterfowl habitat projections to the year 2000 A.D., for example, reveal deficiencies for fall and spring migration use in Saginaw Bay and along the southeastern Michigan coast (U.S. Dept. of Interior, 1971). Habitat deficiencies result in changes in migration patterns which, in turn, may reduce waterfowl hunting success.

Key References

There are few basic references to consult to determine fish and wildlife values in a given wetland. What is perhaps most comprehensive is an environmental impact statement prepared by a public or private agency. However, such statements, although quite detailed, are limited to very few geographical areas. Regionally, a few good reports exist. Scharf's report on Nesting and Migration Areas of Birds of the U. S. Great Lakes (1977), with its inventories and maps, is an excellent source as reflected in the matrix. Wagner et al., (1977) have completed a report on Endangered, Threatened, and Rare Vascular Plants in Michigan for the Michigan DNR. Accompanying the text is an atlas of these plants in Michigan by county. Also included are citations of other investigators who have reported on these unusual flora.

A regional evaluation of muskrats has been completed by Baumgartner (1942). Although not updated, a 
good geographic study by areas in Michigan has been made and the coastal muskrat habitats have been identified and mapped.

Key references on fish, particularly spawning sites, have yet to be prepared for publication. Such data should receive priority since the dollar value of sport fishing is $\$ 286 /$ wetland acre/year. With regard to types of fishes and habitats, Trautman's The Fishes of Ohio (1957) is a useful source.

For waterfow1, the reports of Miller (1943, 1949) and Pirnie (1935) are the most comprehensive references. As with muskrats, the data have not been collectively updated. Therefore, the most current sources of information are in the files of the Wildlife Division of the Michigan DNR.

Future land use and population trends in the Great Lakes Basin, to include the coastal regions of Michigan, have been prepared by the Great Lakes Basin Commission in Ann Arbor. The 17 Appendices published in 1975-76 are comprehensive and include information on wetlands, fish, and wildlife within a regional framework. 


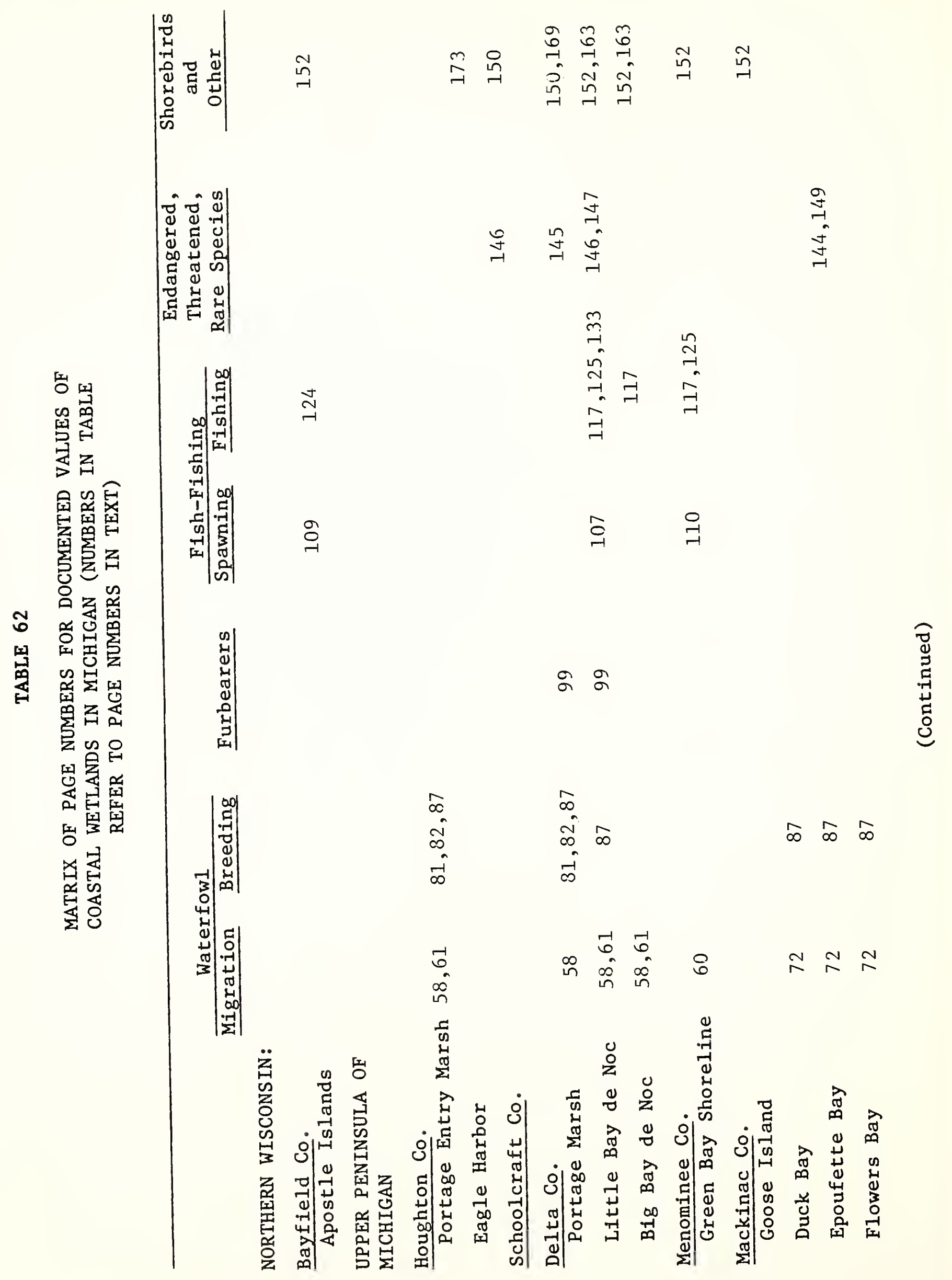




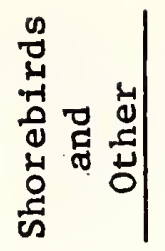

$\stackrel{m}{n} \quad \stackrel{m}{n}$

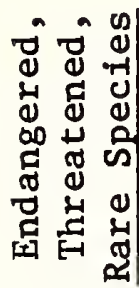

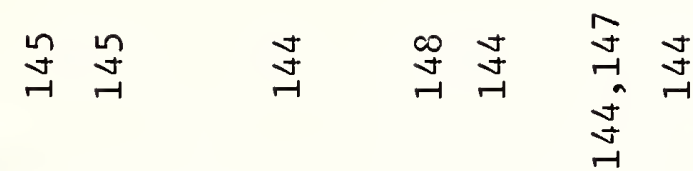

$\stackrel{0}{\text { Na }}$

검

mo
å
an

$\hat{\infty} \hat{\infty}$

$\stackrel{\infty}{\infty} \quad \hat{\infty} \quad \hat{\infty}$

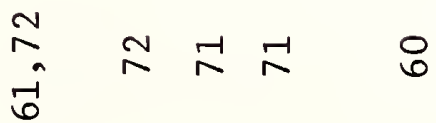

$\underset{0}{\infty} \stackrel{N}{N} \stackrel{N}{N}$

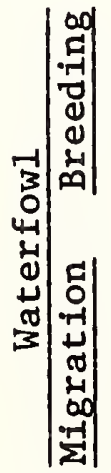

舀 年

$$
\text { ầ }
$$




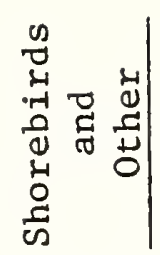

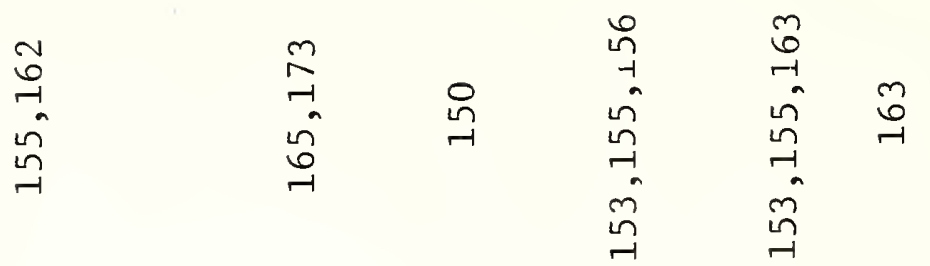

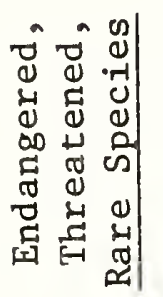

in

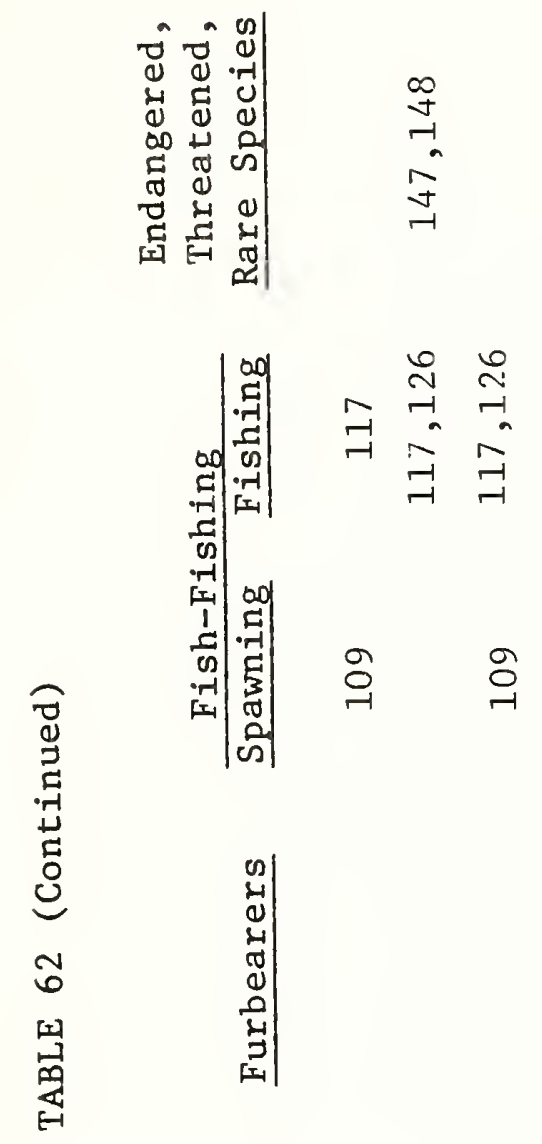

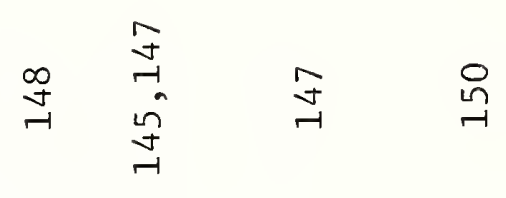

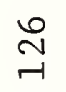

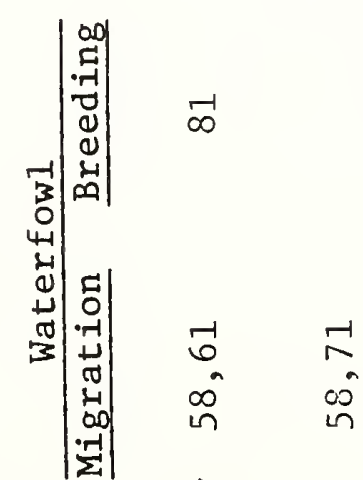

옴

$\stackrel{0}{7}$

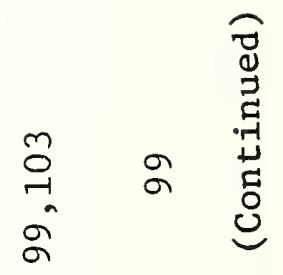

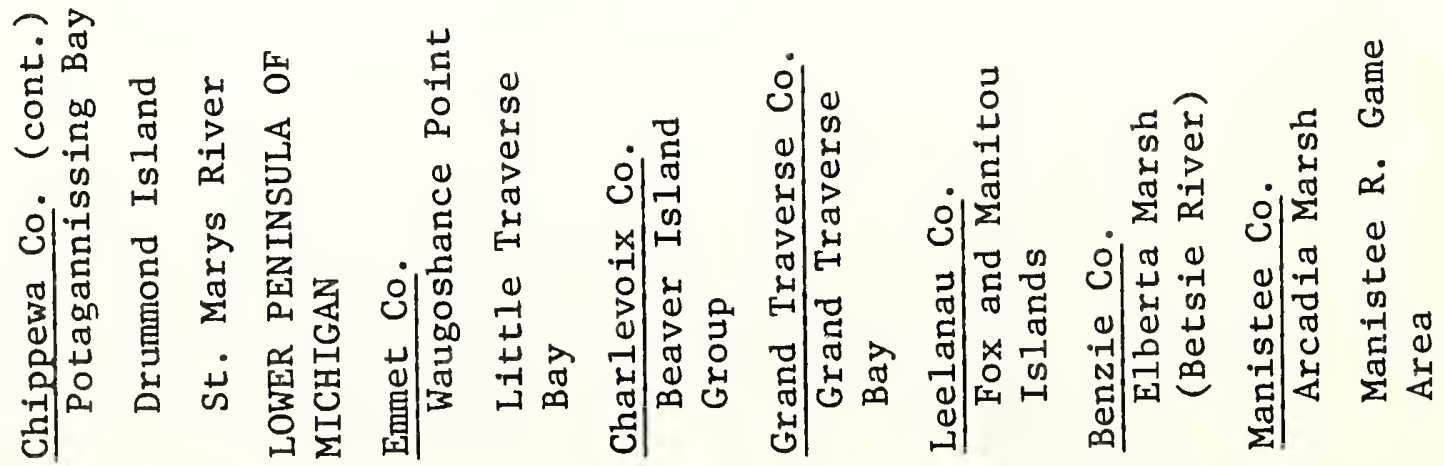




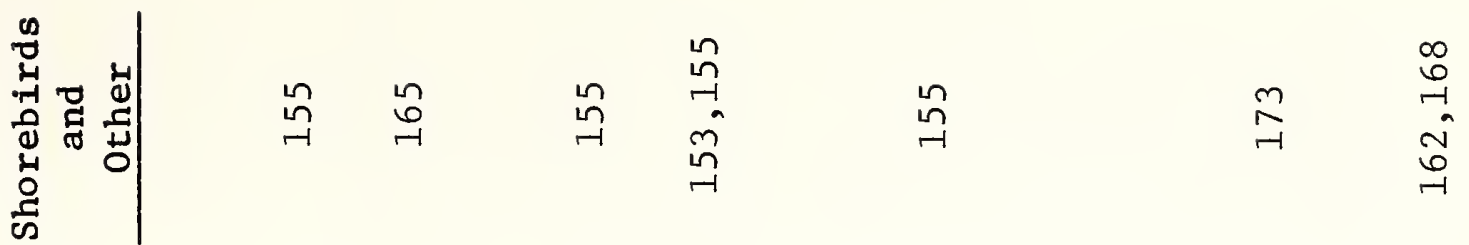
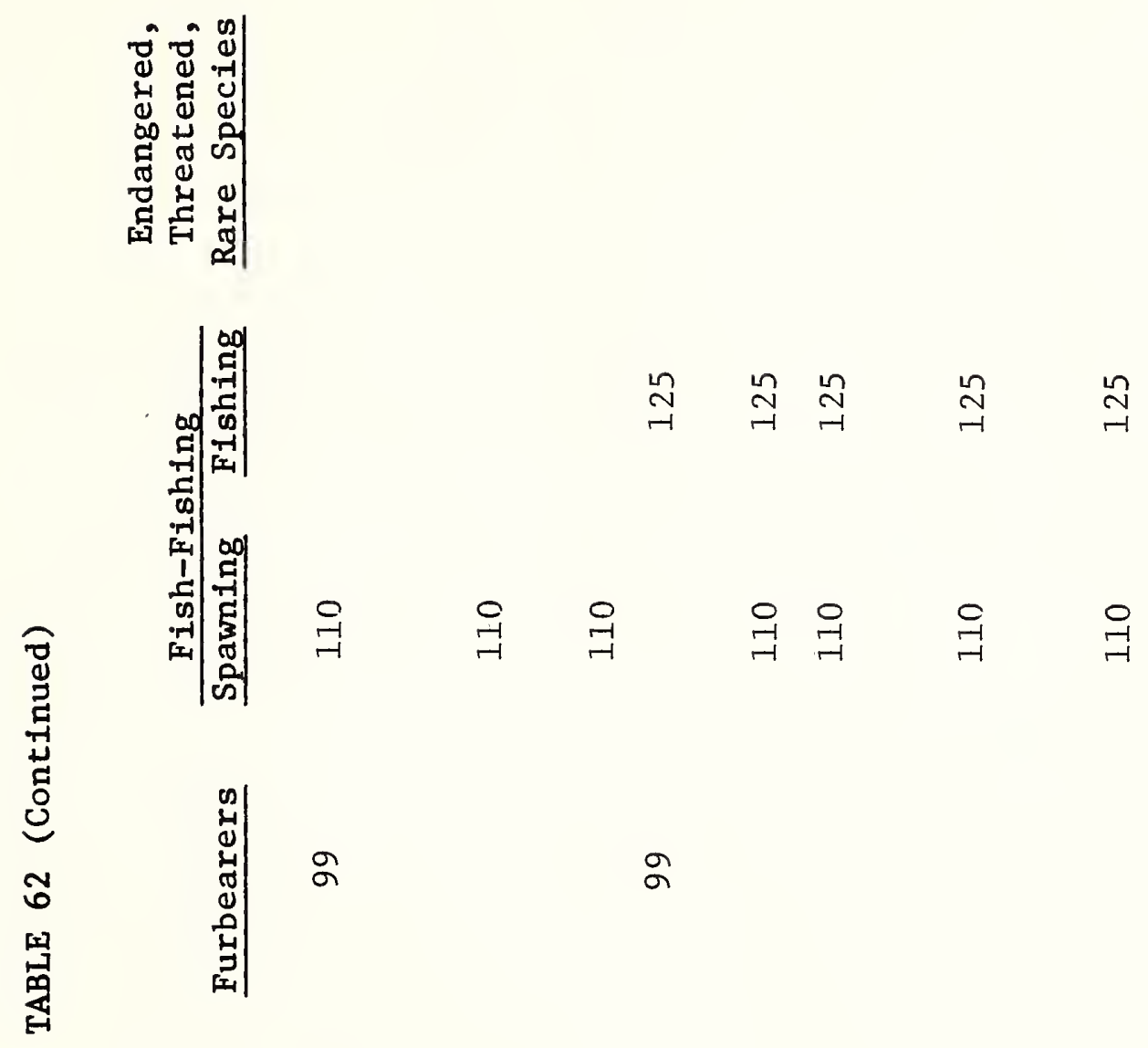

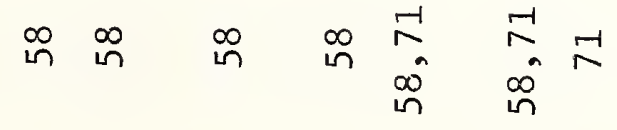

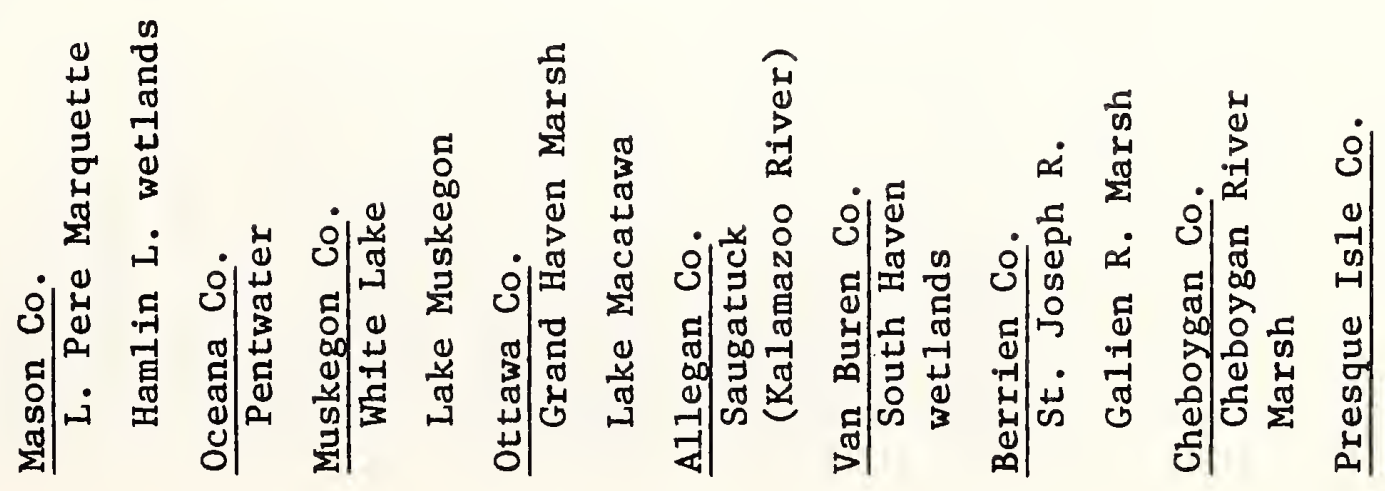




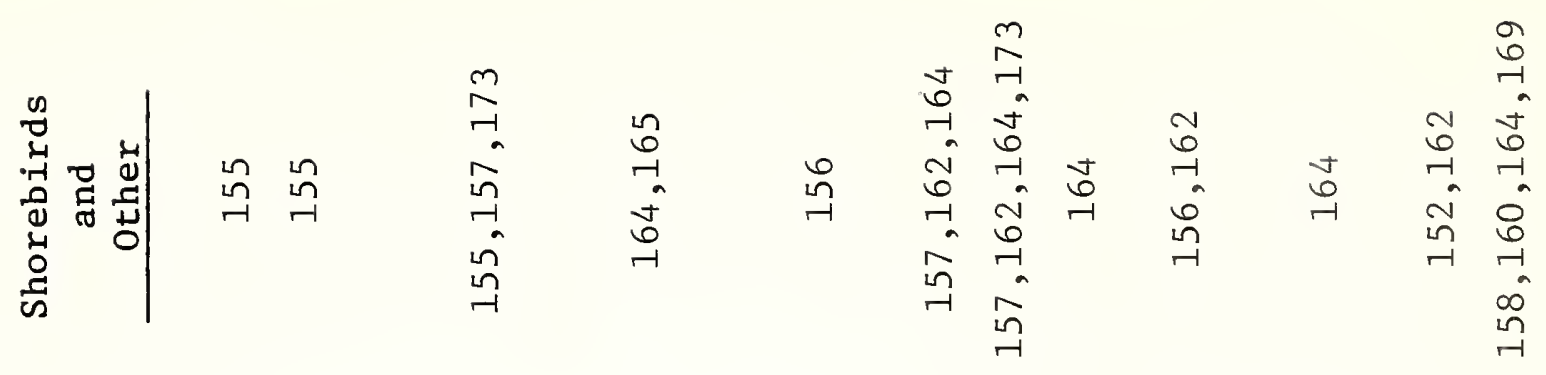

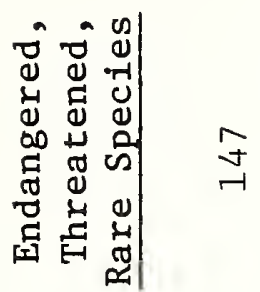

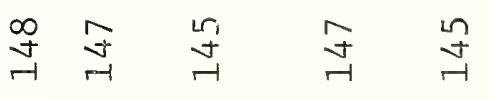

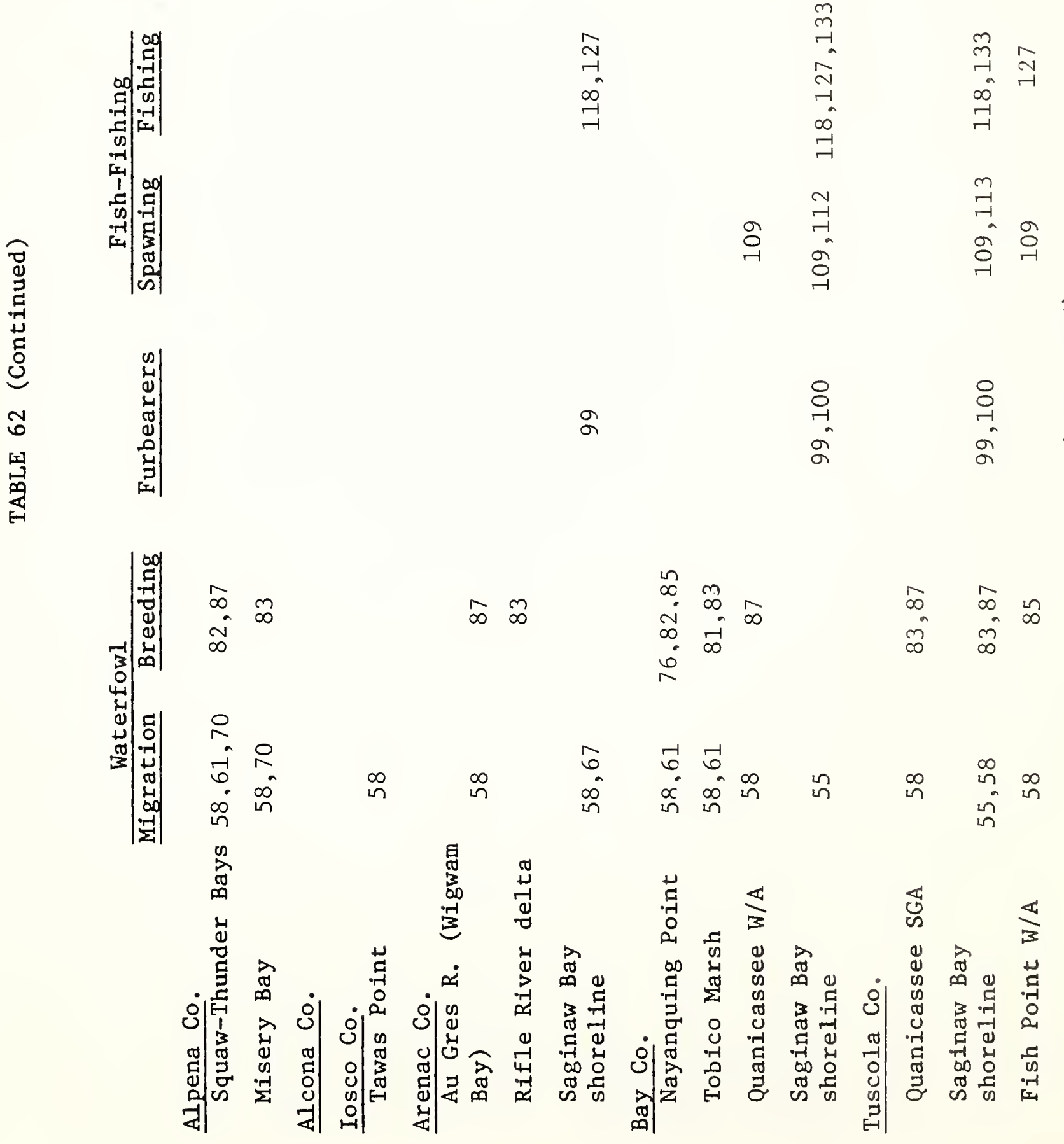




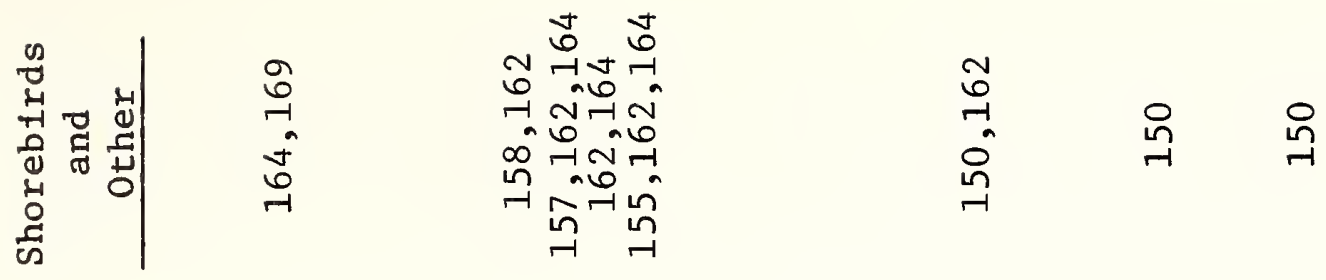

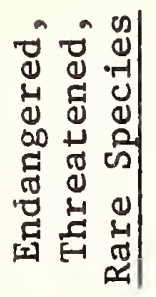

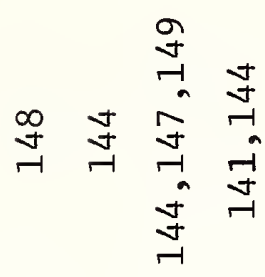

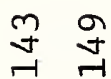

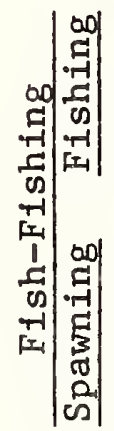

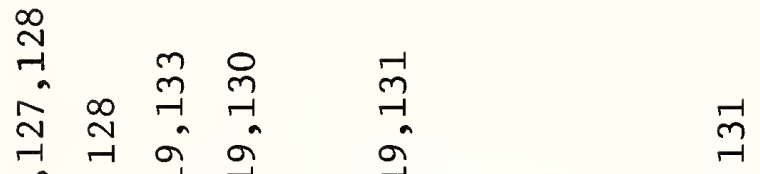

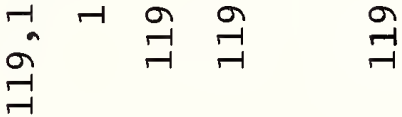

ने ลे รे

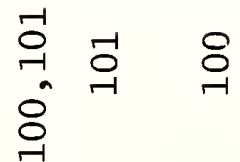

ت્ષ્す

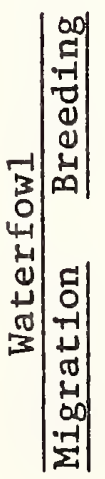

$\begin{array}{lcc}m & m & \\ \infty & \infty & n \\ n & -1 & \infty\end{array}$

$\begin{array}{llll}\hat{\infty} & \hat{\infty} & \hat{\infty} & \hat{\infty} \\ & \hat{\infty} & & \end{array}$

-1
$\infty$
in

นn $\infty$ in in in

చె
$\infty$
ก๊

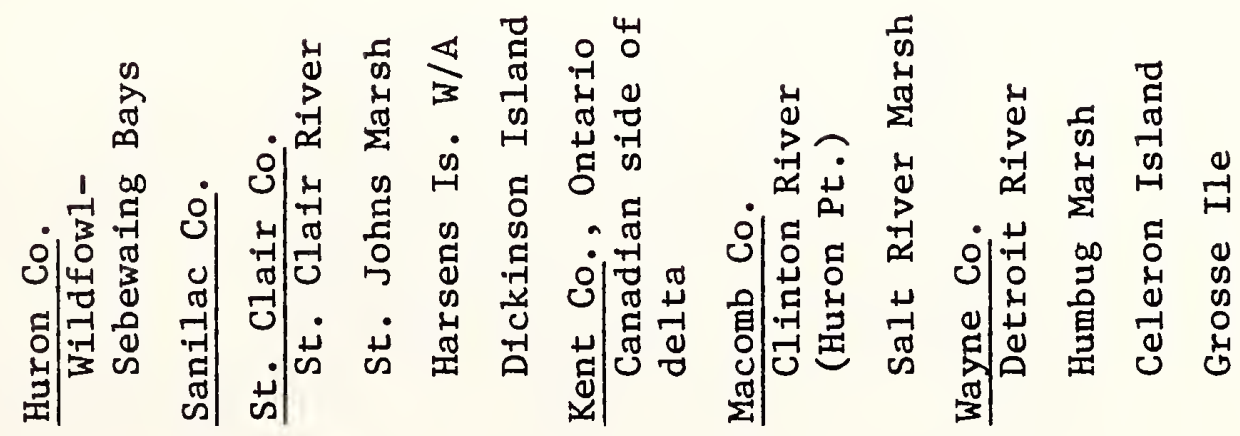


|

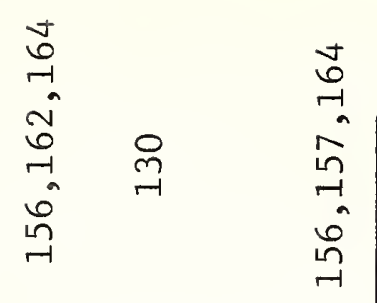

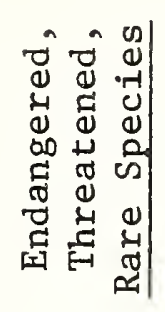

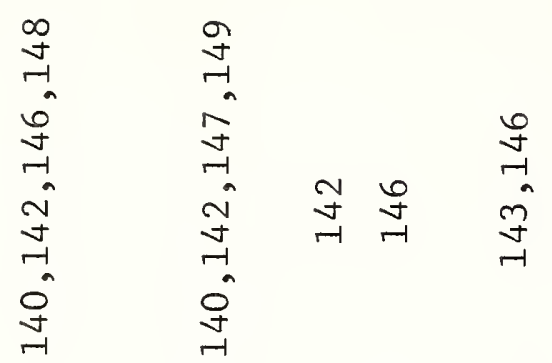

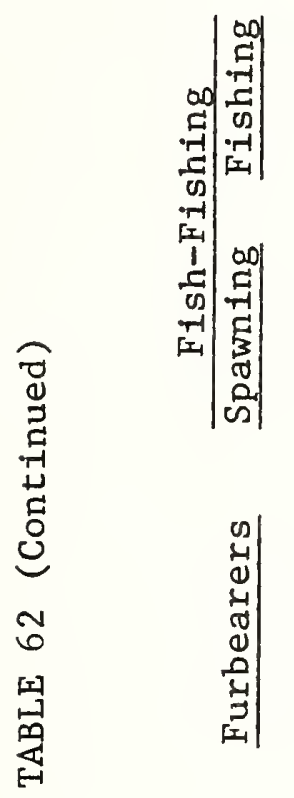

an

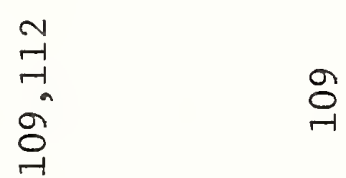

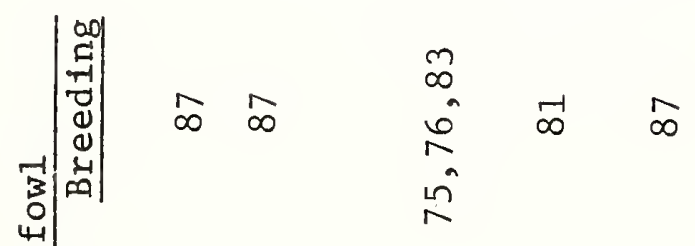

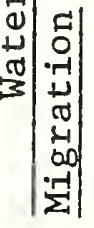

مீ

9

$0_{\substack{-1 \\ 0}}^{-1}$

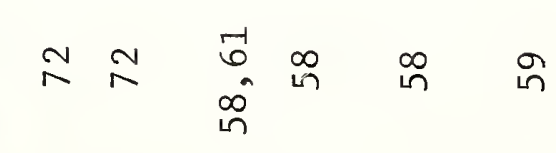

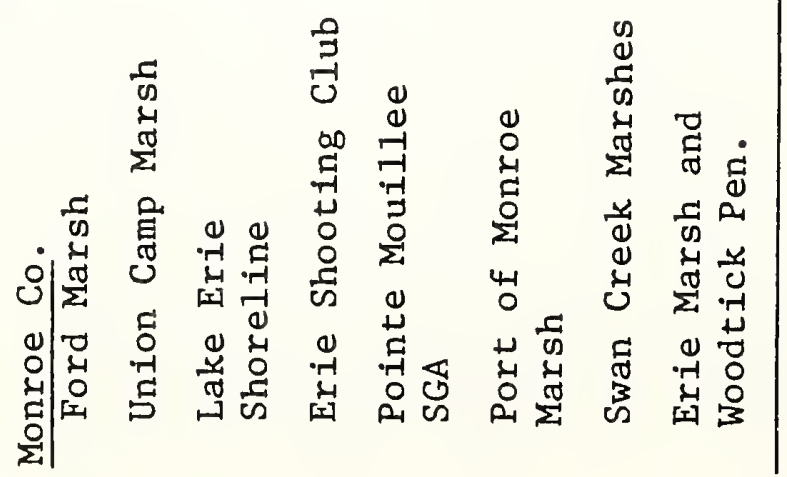


APPENDIX

SCIENTIFIC AND COMMON NAMES OF WATERFOWL WHICH FREQUENT MICHIGAN'S COASTAL WETLANDS

Ducks and Mergansers:

Scientific Name

Aix sponsa

Anas acuta

Anas clypeata

Anas crecca

Anas discors

Anas penelope

Anas platyrhynchos

Anas rubripes

Anas strepera

Aythya affinis

Aythya americana

Aythya collaris

Aythya marila

Aythya valisneria

Bucephala albeola

Bucephala clangula

Clangula hyemalis

Mergus cucullatus

Mergus serrator

Oxyura jamaicensis

Geese and Brant:

Anser caerulescens

Branta bernicla

Branta canadensis

Swans:

Cygnus columbianus
Cygnus cygnus
Cygnus olor
Common Name

Wood Duck

Pintail

Northern Shoveler

Green-winged Teal

Blue-winged Teal

American Widgeon (Baldpate)

Common Mallard

Black Duck

Gadwa11

Lesser Scaup

Redhead

Ring-necked Duck

Breater Scaup

Canvasback

Bufflehead

Common Goldeneye (American Goldeneye)

01dsquaw

Hooded Merganser

Red-breasted Merganser

Ruddy Duck

Snow Goose

Brant Goose

Canada Goose

\section{Coots:}

$\underline{\text { Fulica americana }}$

American Coot

Source: Johnsgaard, 1975, Waterfowl of North America 


\section{REFERENCES CITED}

Anderson, A. A., 1960, Marine Resources of the Corpus Christi Area, Research Monograph No. 21, Bureau of Business Research, University of Texas, Austin, Texas, $44 \mathrm{pp}$.

Andrews, Ralph, 1952, A Study of Waterfowl Nesting on a Lake Erie Marsh, unpublished M.S. thesis, Ohio State University, Columbus, Ohio, $171 \mathrm{pp}$.

Anonymous, 1945, "Report on Waterfowl Abundance and Habitat on Sebewaing Bay," Game Division, Dept. of Conservation, Lansing, MI, 6 pp.

Basch, R. E., 1968, "Age, Growth and Food Habits of the Spottail Shiner, Notropis Hudsonius (Clinton), in Little Bay de Noc, Lake Michigan, " unpublished M.S. thesis, Michigan State University, East Lansing, MI, $42 \mathrm{pp}$.

Baumgartner, Luther L., 1942, Ecological Survey of Muskrat Populations and Habitats, Michigan Department of Natural Resources, Project No. 14-R, 128 pp.

Beak Consultants Inc., 1976, Fisheries Survey of Saginaw Bay Related to the Thermal Effects of the KarnWeadock Generating Stations, A Report for Consumers Power Co., Mississauga, Ontario, 49 pp.

Beaman, John H., 1977, "Commentary on Endangered and Threatened Plants in Michigan," The Michigan Botanist, Vol. 16, pp. 110-122.

Bednarik, Karl E., 1976, "Ohio Wildfowl Hunter Activity and Waterfow1 Harvest, 1957-1974," Wildlife In-Service Note 323, Crane Creek Wildlife Experiment Station, Oak Harbor, Ohio, 25 pp.

Bednarik, Karl E., 1975, "Wildlife Habitat Improvement and Management of the Magee Marsh Wildlife Area, Project Narrative," Crane Creek Wildlife Experiment Station, Oak Harbor, Ohio, 36 pp.

Bednarik, Karl E., et al., 1975, "Environmental Impact

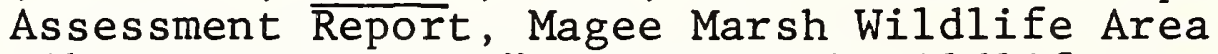
Dike Construction," Crane Creek Wildlife Experiment Station, Oak Harbor, Ohio, 13 pp. 
Bednarik, Karl E. and J. L. Weeks, 1971, "Waterfowl Production in the Lake Erie Marshes," Division of Wildlife, Ohio Department of Natural Resources, Columbus, 24 pp.

Bellrose, F. C., 1976, Ducks, Geese and Swans of North America, 2nd. ed., Stackpole Books, Harrisburg, Pa., 544 pp.

Bellrose, F. C., 1968, "Waterfowl Migration Corridors East of the Rocky Mountains in the United States," Biological Notes No. 61, Illinois History Survey, Urbana, Illinois, $24 \mathrm{pp}$.

Bellrose, Frank C., Jr. and J. B. Low, 1943, "The Influence of Flood and Low Levels on the Survival of Muskrats," Journal of Mammalogy, Vol. 24, No. 2, pp. $173-188$.

Belyea, Glen Y. and J. M. Lerg, 1976, Public Use of Southern Michigan Game and Recreation Areas, Michigan Dept. of Nat. Resources, Wildlife Division Report 2754, 96 pp.

Bennett, Car1 L., 1965, Some Methods of Waterfowl and Marsh Inventories, M.S. thesis, Michigan State University, $77 \mathrm{pp}$.

Benson, D. and R. F. Perry, 1965, "An Acre of Marsh is Worth. . ", The New York State Conservationist, Vo 1. 19, No. 6, pp. 30-33.

Berst, A. H. and G. R. Spangler, 1973, "Lake Huron, the Ecology of the Fish Community and Man's Effect on It," Technical Report No. 21, Great Lakes Fishery Commission, Ann Arbor, MI, 55 pp.

Bowers, E. F. and F. W. Martin, 1975, "Managing Wood Ducks by Population Units," Trans. 40th N. Amer. Wildlife and Natural Resources Conference, pp. 300-324.

Bryan, L., 1976, "Flooding of Monroe County, Michigan: A Comparison of Three Remote Sensor Data Sets," Michigan Academician, Vol. 8, No. 4, pp. 425-440.

Butsch, Robert S., 1954, "The 1953 Spring Shorebird Migration at North Cape, Monroe County, Michigan," The Jack-Pine Warbler, Vol. 32, No. 2, pp. 46-53.

Cable, L. E., 1971, "Inland Fisheries-Fishing in the Interior of the United States," In: Our Changing Fisheries, pp. 324-358, S. Shapiro (ed.), Washington, D. C., U. S. Government Printing Office, $534 \mathrm{pp}$. 
Carney, S. M., M. F. Sorenson and E. M. Martin, 1975, "Distribution of States and Counties of Waterfowl Species Harvested During 1961-1970 Hunting Season," Special Scientific Report, Wildlife No. 187, Fish \& Wildlife Service, Washington, D. C., $\overline{132} \mathrm{pp}$.

Consumers Power Co., 1974, Environmental Report, Quanicassee Plants, Units 1 and 2, Vol. 2, Construction Permit Stage, Jackson, MI, 2-9.1 pp.

Core, E. C., 1949, The Plants of Western Lake Erie After Fifty Years. Unpublished manuscript, Stone Institute of Hydrobiology, Ohio.

Cottrille, B. C., 1957, "Summer Distribution of the Piping Plover in Michigan," The Jack-Pine Warbler, Vol. 35, No. 1, pp. $26-33$.

Cowardin, L. M., and V. Carter, 1975, Tentative Classification for Wetlands of the United States, (mimeographed report) U. S. Fish and WildIife Service, Office of Biological Services, Washington, D.C., $48 \mathrm{pp}$.

Crowe, W. R., 1962, "Homing Behavior in Walleyes," Transactions of American Fisheries Society, Vol. 91, No. 4, pp. 350-354.

Dawson, Steven A., 1975, Waterfowl Food Production and Utilization in Anchor Bay, Lake St. Clair, Michigan, Unpublished M.S. thesis, Ann Arbor, MI, University of Michigan, Wildlife Management, $124 \mathrm{pp}$.

Department of Natural Resources, 1976a, "Proposed St. Johns Marshland Recreation Area," Revised Feb. 1976, Wildlife Division, Lansing, MI, 9 pp.

Department of Natural Resources, 1976b, "The St. Johns Marsh - A Wetland Habitat and Wildlife Analysis," A preliminary unpublished report, Wildlife Division, Department of Natural Resources, Lansing, MI, 24 pp.

Department of Natural Resources, 1976c, "Status of State Game Areas," Sept. 30, 1976, Wildlife Division, Lansing, MI, $1 \mathrm{p}$.

Departmert of Natural Resources, 1975a, Environmental Impact Statement: Dickinson Island and Waterfowl Management Project, Lansing, MI, 27 pp. 
Department of Natural Resources, 1975b, 27th Biennial Report 1973-1974, State of Michigan, Lansing, MI, 323 pp.

Department of Natural Resources, 1973a, Impact on the Karn and Weadock Plants' Operation on Water Quality and Biota in the Saginaw River and Nearshore Areas of Saginaw Bay, Water Resources Commission, Bureau of Water Management, Lansing, MI, $48 \mathrm{pp}$.

Department of Natural Resources, 1973b, 26 Biennial Report 1971-1972, State of Michigan, Lansing, MI, 283 pp.

Department of Natural Resources, 1973c, Shoreland Inventory, Land Resources Division, Lansing, MI, $18 \mathrm{pp}$.

Department of Natural Resources, 1972, "1971 Michigan Sport Fishing Survey Estimates, Appendix A, B, and C," Research \& Development Report No. 268, Survey and Statistics Division, Lansing, MI, $148 \mathrm{pp}$.

Department of Natural Resources, 1971, 25th Biennial Report 1969-1970, State of Michigan, Lansing, MI, $246 \mathrm{pp}$.

Department of Natural Resources, 1969, 24th Biennial Report 1967-1968, State of Michigan, Lansing, MI, 239 pp.

Department of Natural Resources, 1967, 23rd Biennial Report 1965-1966, State of Michigan, Lansing, MI, $239 \mathrm{pp}$.

Department of Natural Resources, Current Files--Great Lakes Fisheries, Fisheries Division, Lansing, MI.

Department of Natural Resources, Current Files--Fingerling Production Data, Fisheries Division, Lansing, MI.

Department of Natural Resources, Current Files--Office of Surveys \& Statistics, Lansing, MI, 1959.

Department of Natural Resources, Permanent File--Muskrats, Wildlife Division, Lansing, MI.

Department of Natural Resources, Permanent File-Waterfowl Aerial Surveys, Wildlife Division, Lansing, MI .

Department of Natural Resources, Permanent File-Waterfowl Breeding Grounds Survey, Wildlife Division, Lansing, MI. 
Department of Natural Resources, Permanent File-Waterfowl Hunting Reservation Program, Wildife Division, Lansing, MI .

Doan, K. H., 1940, "Studies of the Smallmouth Bass," Journal of Wildlife Management, Vol. 4, No. 3, pp. 241-266.

Doan, K. H., 1942, "The Nesting of Smallmouth Bass in Lake Erie from 1938 to 1941, The Ohio Conservation Bulletin (May), pp. 31-32.

Fogle, Ned E., 1975, "Asphalt Angling," Michigan Natural Resources, Vol. 44, No. 4, pp. 18-21.

Fukano, K. G., 1956, "General Creel Census Records for the Connecting Waters Between Lake Huron and Lake Erie, 1953-1955," Research \& Development Report No. 1478, Institute for Fisheries Research, Ann Arbor, MI, $6 \mathrm{pp}$.

Goodwin, R. H., and W. A. Niering, 1975, Inland Wetlands of the United States, Natural History Theme Studies No. 2, U. S. Gov. Printing office, Washington, D. C., $550 \mathrm{pp}$.

Gosselink, J. G., E. P. Odum and R. M. Pope, 1973, "The Value of A Tidal Marsh", Work Paper No. 3, Urban and Regional Development Center, University of Florida, Gainsville, F1a., 30 pp.

Great Lakes Basin Commission, 1976, "Maumee River Basin Level B Study," Preliminary Draft Report, Ann Arbor, MI, 5-6 p p.

Great Lakes Basin Commission, 1975a, "Fish," Appendix 8 Great Lakes Basin Framework Study, Ann Arbor, MI, 290 pP.

Great Lakes Basin Commission, 1975b, "Shore Use and Erosion," Appendix 12, Great Lakes Basin Framework Study, Ann Arbor, MI, 111 pp.

Great Lakes Basin Commission, 1975c "Wildlife," Appendix 17, Great Lakes Basin Framework Study, Ann Arbor, MI, $141 \mathrm{pP}$.

Great Lakes Basin Commission, 1972, "Fish," Appendix 8, Draft No. 2, Great Lakes Basin Framework Study, Ann Arbor, MI, 550 pp.

Greenwood, M. R., 1971, "Untapped Island Fisheries Freshwater Commercial Fishery Resources," In: Our Changing Fisheries, pp. 410-417, S. Shapiro (ed.), Washington, D.C., U.S. Government Printing Office, $534 \mathrm{pp}$. 
Greij, E., 1976, The Effects of a Marsh on Water Quality, Project No. A-007-Mich., Institute of Water Res., Michigan State University, E. Lansing, MI, 24 pp.

Greis, A. D., 1971, "Breeding and Wintering Areas of Mallards harvested in various States and Provinces," Fish \& Wildlife Service Special Sc. Report - Wildlife No. 144, Washington, D.C., U.S. Dept. of Interior, 59 pp.

Hartman, W. I., 1973, Effects of Exploitation, Environmental Changes and New Species on the Fish Habitats and Resources of Lake Erie, Technical Report No. 22, Great Lakes Fish Commission, 43 pp.

Hawn, L. J., 1972, "Michigan Furbearer Catch by Trappers," Research and Development Report No. 257, Department of Natural Resources, Lansing, MI, 3 pp.

Hoffman, Robert D., and H. H. Prince, 1975, "Vegetative Structure and Nest Distribution in a Blackcrowned Night Heron Heronry," The Jack-Pine Warbler, Vo1. 53, No. 3, pp. 95-99.

Howard, D. G., 1972, Near Shore Commercial Fishing in the Western Basin of Lake Erie Centering on the Area Between Monroe and Erie, Michigan, unpublished M.S. thesis, Eastern Michigan University, Ypsilanti, MI, $105 \mathrm{pp}$.

Hubbs, C. I. and K. F. Lagler, 1958, Fishes of the Great Lakes Region, University of Michigan Press, Ann Arbor, MI, 213 pp.

Hunt, G. S., 1963, "Wild Celery in the Lower Detroit River," Ecology, Vol. 44, No. 2, pp. 360-370.

Hunt, G. S., 1957, Causes of Mortality Among Ducks Wintering on the Lower Detroit River, unpublished Ph.D. thesis, University of Michigan, Ann Arbor, MI, 296 pp.

Hunt, G. S., 1952, "Map of Duck Foods in Vicinity of Sugar Island (Detroit River)," Game Division, Dept. of Conservation, Lansing, MI, 1 pp.

Hunt, G. S. and P. G. Mickelson, 1976, Ecological Studies at the Erie Shooting and Fishing Club Marsh and Their Management Implications, Monroe County, Michigan. Erie Research Committee, North American Wildlife Foundation, Washington, D.C., 70 pp. 
International Great Lakes Levels Board, 1973, "Fish, Wildlife and Recreation," Regulation of Great Lakes Water Levels, Appendix D, Washington, D.C., 189 pp.

International Lake Superior Board of Control, 1974, Feasibility Study of Remedial Works in the St. Marys Rapids at Sault Ste. Marie, A Report to the International Joint Commission, Washington, D.C., 8-2 pp.

Jamsen, Gale C., 1976, "Michigan's 1975 Sport Fishery," Surveys and Statistics Services Report No. 156 , Survey \& Statistics Division, Department of Natural Resources, Lansing, MI, 7 pp.

Jamsen, Gale C., 1973, "Assessment of the 1971 Sport Fishery," In: Michigan's Great Lakes Trout and Salmon Fishery 1969-72, Fisheries Management Report No. 5, Department of Natural Resources, Lansing, MI, pp. 20-32.

Jamsen, Gale C., 1972, "1972 Michigan Sport Fishery Survey: All Fishing," Appendix A, Surveys \& Statistics Report No. 122, Surveys \& Statistics Division, Dept. of Natural Resources, Lansing, MI, $51 \mathrm{pp}$.

Jarvis, C. R., 1976, "Fish Point Managed Hunting Report 1976," Wildife Division, Dept. of Natural Resources, Lansing, MI, $10 \mathrm{pp}$.

Jarvis, C. R., 1975a, "Fish Point Managed Hunting Report 1975," Wildlife Division, Department of Natural Resources, Lansing, MI, $10 \mathrm{pp}$.

Jarvis, C. R., 1975b, "Use of Artificial Mallard Nesting Platforms at the Fish Point Wildlife Area 197475," Report No. 2738, Wildlife Division, Department of Natural Resources, Lansing, MI, 6 pp.

Jaworski, Eugene and C. N. Raphael, 1976, "Modification of Coastal Wetlands in Southeastern Michigan and Management Alternatives," Michigan Academician, Vol. 8, No. 3, pp. 303-317.

Jaworski, Eugene and C. N. Raphael, 1973, "A Morphological Comparison of the St. Clair and Mississippi River Deltas," Proced. of the Assoc. of Amer. Geog., Vol. 5, pp. 121-126. 
Jenkins, D. H., 1977, "Wildlife Division Biennial Report," unpublished draft, for 28th Biennial Report 19751976, Dept. of Natural Resources, 52 pp.

Johnsgaard, Paul A., 1975, Waterfowl of North America, Indiana University Press, Bloomington, Indiana, 575 pp.

Kaatz, Martin, R., 1955, "The Black Swamp: A Study in Historical Geography," Annals of the Association of American Geographers, Vo1. 35, No. 1, pp. 1-35.

Kadlec, John A. and W. A. Wentz, 1974, State-of-the-Art Survey and Evaluation of Marsh Plant Establishment Techniques: Induced and Natural, School of Natural Resources, University of Michigan, 265 pp.

Kelley, A. H., 1972, "Spring Migration at Whitefish Point, 1966-1971," The Jack-Pine Warbler, Vol. 50, No. 3, pp. 69-75.

Kelley, N. T. and A. H. Kelley, 1973, "Fall Migration at Tawas Point," The Jack-Pine Warbler, Vol. 51, No. 3, pp. $111-115$.

Koechlein, Alan L., 1971, Nest Site Selection by Mute Swans in the Grand Traverse Bay Area, Michigan, M.S. thesis, Dept. of Fisheries and Wildlife, Michigan State University, 48 pp.

Kreisman, J., J. McDonald, G. Rosenbaum, and J. Snyder, 1976, Coastal Wetlands with Emphasis on Freshwater Systems, School of Natural Resources, University of Michigan, Ann Arbor, 185 pp.

Lagler, Karl, F., 1954, "Michigan Turtles," Michigan Conservation, Vol. 23 , No. 3 , pp. $3-6$.

Lake Erie Research Unit Staff, 1976, "Status of the Ohio Lake Erie Fisheries," Division of Wildlife Department of Natural Resources, Sandusky, Ohio, $20 \mathrm{pp}$.

Lake St. Clair Advisory Committee, 1975, "Fishing Chart and Guide, Lake St. Clair, St. Clair River, and Upper Detroit River," St. Clair Consultants, Royal Oak, MI, 12 pp.

Langlois, Thomas H., 1954, The Western End of Lake Erie and Its Ecology, J. W. Edwards, Ann Arbor, $479 \mathrm{pp}$.

Larson, Joseph S. (ed.), 1976, Models for Evaluation of Freshwater Wetlands, Water Resources Research Publication No. 32, University of Massachusetts, Amherst, 91 pp. 
Latta, William C., 1963, "The Life History of the Smallmouth Bass, Micropterus d. dolomieui, at Waugoshance Point, Lake Michigan," Bulletin of the Fisheries Research No. 5, Department of ConservaEion, Lansing, MI, $56 \mathrm{pp}$.

Latta, William C., 1957, "The Ecology of the Smallmouth Bass, Micropterus d. dolomieui Lacepede, at Waugoshance Point, Lake Michigan," Institute for Fisheries Research Report No. 1514, Institute for Fisheries Research, Ann Arbor, MI, 114 pp.

Latta, William C., 1954, "Some Observations on the Spawning of the Smallmouth Bass, Micropterus d. dolomieui, in Lake St. Clair during the Spring of 1953," Fisheries Research Institute Report No. 1419, Fisheries Research Institute, Michigan Department of Natural Resources, Ann Arbor, MI, $7 \mathrm{pp}$.

Lawrie, A. H. and J. F. Rahrer, 1973, "Lake Superior, A Case History of the Lake and its Fisheries," Technical Report No. 19, Great Lakes Fishery Commission, Ann Arbor, MI, 69 pp.

Lowe, D. S. et al., 1976, Remote Sensing in Michigan for Land Resource Management, Report No. NASA CR-ERIM 193400-13-P, Envir. Research Institute of Michigan, Ann Arbor, MI, 79 pp.

Manville, Richard H., 1952, The Snakes of Michigan, Cooperative Extension Service, Extension Bulletin 315, Michigan State College, 20 pp.

Martz, Gerald, F., 1977a, "Suggested Next 5-year Acquisition Program," Wildlife Division, Department of Natural Resources, Lansing, MI, 1 p.

Martz, Gerald, F., 1977b, "Island Nesting Report," (unfinished draft), Wildlife Division, Department of Natural Resources, Lansing, MI, 23 pp.

Martz, Gerald F., 1976, "The Mississippi Flyway Waterfow1 Habitat Reconnaissance," Wildlife Division, Department of Natural Resources, Lansing, MI, $16 \mathrm{pp}$.

Martz, Gerald, F., (undated), "Waterfowl Breeding Ground Surveys, 1951-1966," unpublished report, Wildlife Division, Department of Natural Resources, Lansing, MI. 
Martz, G. F. et al., 1972, "The 1971 Point System Compared to the Fixed-Bay-Limit Waterfowl Seasons of 1961-70," Research \& Development Report No. 280, Wildlife Division, Department of Natural Resources, Lansing, MI, $20 \mathrm{pp}$.

Martz, G. F. and D. Ostyn, 1977, "Recovery Patterns of Banded Scaup Harvested in Michigan, 1964-73," Report No. 2753, Wildlife Division, Department of Natural Resources, Lansing, MI, 17 pp.

Mathiak, H. A. and A. F. Linde, 1954, "Role of Refuges in Muskrat Management," Technical Wildlife Bulletin No. 10, (P-R Project 15-R), Wisconsin Conservation Dept., $16 \mathrm{pp}$.

McDonald, Malcom E., 1951, The Ecology of the Pointe Mouillee Marsh, Michigan with Special Reference to the Biology of Cattail (Typha), Microfilm No. 2795, University of Michigan, Ann Arbor, MI, 243 pp.

Messman, L., et al., 1977, Wetland Values, Planning and Evaluation Methodology, Fort Belvoir, Va., U.S. Army Engineers, Institute of Water Resources, $214 \mathrm{pp}$.

Mikula, E. J., 1965, "Waterfowl Breeding Grounds Surveys in Michigan," Game Division Report No. 2479, Dept. of Natural Resources, Lansing, MI, 4 pp.

Miller, H. J., 1962, "Development and Preservation of Wildife Habitat in the Great Lakes Shoreline," Game Division Report No. 2391, Department of Conservation, Lansing, MI, $12 \mathrm{pp}$.

Miller, H. J., 1958, "Waterfowl Habitat - Michigan," Department of Conservation, Lansing, MI, $6 \mathrm{pp}$.

Miller, H. J., 1954, "Letter Pertaining to Drainage and its Effects on Past, Present and Future Waterfowl Utilization of the Wetlands of Michigan, Department of Conservation, Game Division, Lansing, MI.

Miller, H. J., 1949, "Waterfowl Breeding Ground Cover, 1949, in Michigan," Game Division Report No. 1038, Department of Conservation, Lansing, MI, $6 \mathrm{pp}$. 
Miller, H. J., 1943, Waterfowl Survey, Saginaw Bay - Lake St. Clair - Lake Erie, Project No. 13-R, Wildlife Division, Department of Natural Resources, Lansing, MI, $132 \mathrm{pp}$.

Mississippi Flyway Council, "Retrieved Waterfowl Harvest Data, 1965-1974," unnumbered data sheets, from personal files, Edward J. Mikula, Wildlife Division, Dept. of Natural Resources, Lansing, MI.

Natural Areas Coordinator, Paul Rasmussen, Land Resources Division, Dept. of Natural Resources, Lansing, MI .

Office of Planning Services, 1975, Michigan Recreation Plan 1974, Department of Natural Resources, Lansing, MI, 348 pp.

Ohio Division of Wildlife, 1976, "Proposed Cooperative State-Managed Canada Goose Hunting Program on the Ottawa National Wildlife Refuge, Ohio," Draft Environmental Assessment, Department of Natural Resources, Columbus, Ohio, 27 pp.

Panzner, E. Robert, 1955, Wetlands Inventory of Michigan, U.S. Department of the Interior, Fish and Wildlife Service, Minneapolis, MN, 22 pp.

Parkhurst, B. R., 1971, The Distribution and Growth of the Fish Populations Along Western Shore of Lake Erie at Monroe, Michigan, During 1970. Unpublished M.S. thesis, Michigan State University, East Lansing, MI, $71 \mathrm{pp}$.

Parsons, J. W., 1974, "Striped Bass (Morone saxatilis): Distribution, Abundance, Biology, and Propagation in N. America and Suitability for Introduction into the Great Lakes," Greak Lakes Fishery Laboratory, Bureau of Sport Fisheries \& Wildlife, Ann Arbor, MI, 74 pp.

Payne, Brian, R. and Richard M. DeGraaf, 1975, "Economic Value Associated with Human Enjoyment of Nongame Birds," Proceedings, Symposium on Management of Forest and Range Habitats for Nongame Birds, Gen. Tech. Rept. No. WO-1, Forest Service, U.S. Department of Agriculture, Washington, D.C., pp. 6-10. 
Personal Communication, Karl Bednarik, Crane Creek Wildlife Experiment Station, Oak Harbor, Ohio.

Personal Communication, Bob Craig, Economic Analyst, Land Resources Program Division, Department of Natural Resources, Lansing, MI.

Personal Communication, Randy L. Eshenroder, Director, Lake Huron Field Station at Alpena, Michigan, Fisheries Division, Michigan Department of Natural Resources.

Personal Communication, Ned E. Fogle, Great Lakes Fisheries, Fisheries Division, Michigan Department of Natural Resources, Lansing, MI.

Personal Communication, Robert Haas, Director, Lake St. Clair Field Station, at Mount Clemens, Fisheries Division, Michigan Department of Natural Resources.

Personal Communication, Richard Julian, U.S. Fish and Wildlife Service, Lansing, Michigan.

Personal Communication, Daniel Kitchel, Economist, Recreation Services Division, Michigan Department of Natural Resources.

Personal Communication, Gerald F. Martz, Wetlands Specialist, Wildlife Division, Michigan Department of Natural Resources, Lansing, MI.

Personal Communication, Bill McClay, Fisheries Division, Michigan Dept. of Natural Resources.

Personal Communication, Edward J. Mikula, Waterfow1 Specialist, Wildlife Division, Michigan Department of Natural Resources, Lansing, MI.

Personal Communication, Gregory 0lson, Fisheries Biologist, Lake St. Clair Great Lakes Research Station, at Mount Clemens, Michigan. Fisheries Division, Michigan Department of Natural Resources.

Personal Communication, Leo B. Pospichal, Wetlands Specialist, Wildlife Division, Michigan Department of Natural Resources, Lansing, MI.

Personal Communication, Harold Prince, Associate Professor, Dept. of Fisheries \& Wildlife, Michigan State University, E. Lansing, MI. 
Personal Communication, Paul C. Rasmussen, Planner, Office of Planning Services, Michigan Department of Natural Resources, Lansing, MI.

Personal Communication, John M. Shauver, Bureau of Environmental Protection, Water Quality Division, Michigan Dept. of Natural Resources, Lansing, MI.

Personal Communication, Ronald J. Spitler, Fisheries Biologist, District 14, Pontiac, MI.

Personal Communication, Chuck Wolverton, Shorelands Manager, Land Resources Division, Michigan Department of Natural Resources.

Pinsak, A. P. and T. L. Meyer, 1976, Environmental BaseIine for Maumee Bay: Maumee River Basin Level B Study, Great Lakes Basin Commission, Ann Arbor, MI, I94 pp.

Pirie, R. G. (ed.), 1973, Oceanography, Contemporary Readings in Ocean Sciences, Oxford University Press, New York, 530 pp.

Pirnie, Miles D., 1935, Michigan Waterfowl Management, Game Division, Department of Conservation, Lansing, MI, 328 pp.

Pospicha1, Leo B., 1976, "I976 Waterfowl Hunting Season Report, St. Clair Flats Wildlife Area," Wildlife Division, Department of Natural Resources, Lansing, MI, $6 \mathrm{pp}$.

Pospichal, Leo B., 1975, "1975 Waterfowl Hunting Season Report, St. Clair Flats Wildlife Area," Wildlife Division, Department of Natural Resources, Lansing, MI, 5 pp.

Pospichal, Leo B., 1974, "1974 Waterfowl Hunting Season Report, St. Clair Flats Wildlife Area," Wildlife Division, Department of Natural Resources, Lansing, MI, $5 \mathrm{pp}$.

Pospichal, Leo (undated) Preliminary Management Plan for St. Clair Flats Wildlife Area, Department of Natural Resources, Lansing, MI, 17 pp.

Price, B. and T. Kelly, 1976, Fishes of the Grand Traverse Bay Region, MICHU-SG-76-100, Michigan Sea Grant Program, Ann Arbor, MI, 54 pp. 
Regier, H. A., and W. L. Hartman, 1973, "Lake Erie's Fish Community: 150 Years of Cultural Stress," Science, Vol. 180, pp. 1248-1255.

Regier, H. A. et al., 1969, "The Ecology and Management of the Walleye in Western Lake Erie," Technical Report No. 15, Great Lakes Fishery Commission, Ann Arbor, MI, 101 pp.

Ricker, W. E., 1975, Computation and Interpretation of Biological Statistics of Fish Populations, Bulletin 191, Ottawa, Ontario. Fisheries Research Board of Canada, $382 \mathrm{pp}$.

Roller, Norman, E. G., 1976, Changes in the Wetlands and Land-Use Patterns of St. Johns Marsh, St. Clair County, Michigan. Environmental Research Institute of Michigan, Ann Arbor, 6 pp.

Sanderson, Glen C., (ed.), 1977, The Management of Migratory Shore and Upland Game Birds in North America, International Association of Fish and Wildlife Agencies, Washington, D.C., $358 \mathrm{pp}$.

Sather, J.H. (ed.), 1976, Proceedings of the National Wetland Classification and Inventory Workshop, U.S. Fish and Wildlife Service, Office of Biological Services, Washington, D.C., 110 pp.

Scharf, William C., 1977, Nesting and Migration Areas of Birds of the U.S. Great Lakes, prepared for U.S. Department of Interior, Office of Biological Services, Fish and Wildlife Service, Bay St. Louis, Mississippi, $253 \mathrm{pp}$.

Schemenauer, L. G., 1963, "Report of Recreational Use of Pointe Mouillee State Game Area," Report No. 2413, Game Division, Department of Conservation, Lansing, MI, $4 \mathrm{pp}$.

Schrouder, J. C., 1975, "The Muskellunge in Michigan," Fisheries Division Pamphlet No. 45, Department of Natural Resources, Fisheries Division, Lansing, MI, $7 \mathrm{pp}$.

Scott, J. A., 1977, "Fisheries Division Biennial Report," for 28th Biennial Report 1975-1976, unpublished Fisheries Division, Department of Natural Resources, Lansing, MI, $13 \mathrm{pp}$.

Scott, W. B. and E. J. Crossman, 1973, Freshwater Fishes of Canada, Fisheries Research Board of Canada Ottawa, $966 \mathrm{pp}$. 
Sellman, A., et al., 1974, Remote Sensing in Michigan for Land Resource Management, Report No. NASA CR-ERIM 193400-1-T, Environ. Res. Inst. of Mich., Ann Arbor, $43 \mathrm{pp}$.

Shaw, Samual, P. and C. G. Fredine, 1956, Wetlands of the United States, U. S. Dept. of Interior, Fish and Wildlife Service, Circular 39, Washington, D.C., $67 \mathrm{pp}$.

Sheldon, William, 1965, "Hawk Migration in Michigan and the Straits of Mackinac," The Jack-Pine Warbler, Vol. 43, No. 2, pp. 79-83.

Shepherd, R. E., 1973 "Inventory of Fish and Evaluation of Water Quality During Minimum Flow Period in The River Raisin, August 1971," Fisheries Division, Department of Natural Resources, Lansing, MI, 64 pp.

State of Michigan, 1967, "Water Resource Ues, Present and Prospective, for the Menominee and Montreal River Basins in Michigan," Water Resources Commission, Lansing, MI, $59 \mathrm{pp}$.

Stroud, R. H., 1977, "Changing Challenges in Recreational Fisheries," Sport Fishery Institute Bulletin No. 284 (May), washington, D. C., 6 pp.

Stuever, F. W., 1941, "Raccoon Management Investigation," Final Report Wildlife Research, Game Division, Department of Conservation, Lansing, MI, 170 pp.

Sullivan, Peter, 1976, "Versatile Wetlands - An Endangered Species," reprint from Conservation News, Oct., $15,5 \mathrm{pp}$.

Switzenberg, D. F., 1952, "Michigan Snakes," Michigan Conservation, Vol. 21 , No. 4, pp. 1-5.

Talhelm, Daniel, in preparation, "Fishery Economics of the Great Lakes," Michigan State University, East Lansing, MI, $9 \mathrm{pp}$.

Thobaben, Robert G., Jr., 1974 a (unpublished report), Cheboygan Marsh, Biological Field Camp Report, University of Michigan, Ann Arbor, MI, 3 pp.

Thobaben, Robert G., Jr., 1974b (unpublished report), The Relative Abundance of Birds in the Cheboygan Marsh, Investigations in Ornithology, University of Michigan, Ann Arbor, MI, 35 pp. 
Thompson, D. W., 1964, A Study of Waterfowl Nesting in the Southwest Lake Erie Region, unpublished M.S. thesis, Ohio State University, Columbus, Ohio, $80 \mathrm{pp}$.

Tilton, D. L., 1976, Freshwater Wetlands and Sewage Effluent Disposal, School of Natural Resources, University of Michigan, $343 \mathrm{pp}$.

Trautman, M. B., 1957, The Fishes of Ohio, Ohio State University Press, Columbus, Ohio, 683 pp.

Urban, David, 1968, The Ecology of Raccoons on a Managed Waterfowl Marsh in Southwestern Lake Erie, M.S. thesis, Ohio State University, Columbus, 98 pp.

U.S. Army, 1976a, Environmental Statement Ottawa River Harbor, Corps of Engineers, Detroit District, Detroit, MI, $80 \mathrm{pp}$.

U.S. Army, 1976b, Final Environmental Statement Maintenance Dredging of the Federal Navigation Channel at Monroe Harbor, Michigan, Corps of Engineers, Detroit District, $131 \mathrm{pp}$.

U.S. Army, 1976c, Shoreline Flood Protection Study, Monroe County, Michigan, Corps of Engineers, Detroit District, 236 pp.

U.S. Army 1974a, Final Environmental Statement Confined Disposal Facility at Pointe Mouillee for Detroit and Rouge Rivers, Corps of Engineers, Detroit District, $256 \mathrm{pp}$.

U.S. Army, 1974b, Proposed Diked Disposal Area on Dickinson Island, St. Clair County, Michigan, Corps of Engineers, $234 \mathrm{pp}$.

U. S. Army Corps of Engineers, 1971, National Shoreline Study, Vol. 5, U.S. Government Printing Office, Washington, D.C., 362 pp.

U.S. Department of Agriculture, 1977, "The Nation's Renewable Resources - An Assessment, 1975," Forest Resources Report No. 21, Forest Service, Washington, D.C., 243 pp.

U.S. Department of Interior, 1976, Lake Summary Reports, Fish \& Wildlife Service, Washington, D.C., $4 \mathrm{pp}$.

U.S. Department of Interior, 1972, "National Survey of Fishing and Hunting 1970," Resource Publication 95, Fish \& Wildlife Service, Washington, D.C., $108 \mathrm{pp}$. 
U.S. Department of Interior, 1971, "Flyway Habitat Management Unit Project," FHMUP Report No. 8, Division of Wildife Refuges, Bureau of Sport Fisheries and Wildife, Washington, D.C., 5 pp. plus appendices.

U.S. Department of Interior, 1970a, Fish and Wildlife as Related to Water Quality of the Lake Superior Basin, A Special Report on Fish and Wildlife Resources, Fish and Wildlife Service, Washington, D.C., 151 pp.

U.S. Department of Interior, 1970b, National Estuary Study, Vol. 3, U.S. Government Printing Office, Washington, D.C., $326 \mathrm{pp}$.

U.S. Department of Interior, 1969, Fish and Wildlife as Related to Water Quality of the Lake Huron Basin, A Special Report on Fish and Wildlife Resources, Fish and Wildlife Service, Washington, D.C., 134 pp.

U.S. Department of Interior, 1967, Fish and Wildlife as Related to Water Quality of the Lake Erie Basin, U.S. Fish and Wildlife Service, Washington, D.C., $170 \mathrm{pp}$.

U.S. Fish and Wildlife Service, 1976, "Federal Waterfowl Hunting Estimates," Administrative Report Series, unnumbered, Department of Interior.

Van der Schalie, H., 1975, "An Ecological Approach to Rare and Endangered Species in the Great Lakes Region," Michigan Academician, Vol. 8, No. 1, pp. 7-22.

Veatch, Jethro, 0., 1939, "Patterns Based upon the Distribution of Swamp Land in Michigan," Michigan Academy of Science, Arts and Letters, Vol. 24, Part 3, pp. 93-106.

Wagner, W. C., 1972, "Utilization of Alewives by Inshore Piscivorous Fishes in Lake Michigan," Transactions of the American Fisheries Society, Vol. 101, No. I, PP. 55-63.

Wagner, W. C., 1968, "The Sport Fishery on Little Bay de Noc, 1965," Research and Development Report No. 146, Institute for Fisheries Research Report No. 1748, Fisheries Division, Department of Natural Resources, Lansing, MI, 20 pp. 
Wagner, W. J., et al., 1977 (in preparation), Endangered, Threatened and Rare Vascular Plants in Michigan, for the Department of Natural Resources, Lansing, MI, 24 pp.

Weeks, J. L., 1974, "Ohio Wetlands and Wildlife Ecology Research and Management," Federal Aid Project W-104-R-16, Division of Wildlife, Department of Natural Resources, Columbus, Ohio, 16 pp.

Weller, M. W. and C. E. Spatcher, 1965, "Role of Habitat in the Distribution and Abundance of Marsh Birds," Special Report No. 43, Agricultural and Home Economics Experiment Station, Iowa State University, Ames, Iowa, $31 \mathrm{pp}$.

Wells, La Rue and A. L. McLain, 1973, Lake Michigan-Man's Effects on Native Fish Stocks and Other Biota, Technical Report No. 20, Great Lakes Fishery Commission, Ann Arbor, MI, 55 pp.

Welty, Joel, C., 1975, The Life of Birds, 2nd ed., W. B. Saunders Co., Philadelphia, 623 pp.

Westerman, F. A. and J. Van Oosten, 1937, "Fisheries of Potagannissing Bay, Michigan," Department of Conservation, Lansing, MI, $81 \mathrm{pp}$.

Wickland, R. G. and B. C. Dean, 1957, "Watershed Survey Report, Little Manistee River Watershed, Survey and Plans Report," Dingell-Johnson Project F4R7 Department of Conservation, Lansing, MI, 17 PP.

Williams, J. E. and B. L. Jacob, 1971, "Management of Spawning Marshes for Northern Pike," Research and Development Report No. 242, Fisheries Division, Department of Natural Resources, Lansing, MI, $22 \mathrm{pp}$.

Wing, Leonard W., 1956, Natural History of Birds, Ronald Press Co., New York, 539 pp.

Woodby, Douglas A., 1974, (unpublished report), Distribution and Potential Productivity of Birds in the Cheboygan Marsh, Biological Field Camp Report University of Michigan, Ann Arbor, MI, 16 pp.

Wright, A. T. and R. Schorfhaar, 1976, "Summary of August, 1975, St. Mary's River Synoptic Fish Survey,"

Fisheries Division, Department of Natural Resources, Lansing, MI, $10 \mathrm{pp}$. 






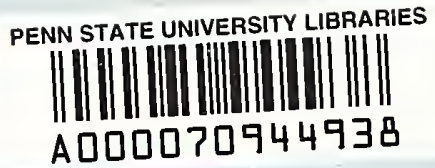

